До 100-річчя

Національної академії наук України 
НАЦІОНАЛЬНА АКАДЕМІЯ НАУК УКРАЇНИ УКРАЇНСЬКИЙ МОВНО-ІНФОРМАЦІЙНИЙ ФОНД

\section{ЛІНГВІСТИЧНО-ІНФОРМАЦІЙНІ СТУДІї}

\section{ПРАЦІ \\ УКРАЇНСЬКОГО МОВНО-ІНФОРМАЦЙННОГО ФОНДУ НАН УКРАЇНИ}

\section{У П’ЯТИ ТОМАХ}

Дослідження 1991-2018 років

За загальною редакцією $B$. А. Широкова

КИїВ 2018 


\section{НАЦІОНАЛЬНА АКАДЕМІЯ НАУК УКРАЇНИ УКРАЇНСЬКИЙ МОВНО-ІНФОРМАЦЙНИЙ ФОНД}

TOM IV

\section{КОРПУСНА ТА КОГНІТИВНА ЛІНГВІСТИКА}


Рекомендовано до друку вченою радою

Украйнського мовно-інформачійного фонду НАН Украӥни

(протокол № 9 від 23 жовтня 2018 р.)

Рецензенти:

академік НАН України О. В. Палагін, член-кореспондент НАН України $A$. О. Загнітко

Автори четвертого тому:

В. А. Широков, О. В. Бугаков, Н. М. Заїка, Т. О. Грязнухіна, М. О. Кригін, М. В. Надутенко, О. Г. Рабулець, Н. М. Сидорчук, Л. О. Терещенко, І. В. Шевченко, О. О. Шипнівська, С. С. Ющенко, К. М. Якименко

Лінгвістично-інформаційні студії : праці Українського мовно-інформаційного фонду НАН України : у 5 т. / В. А. Широков та ін. Т. 4 : Корпусна та когнітивна лінгвістика. Київ. Український мовно-інформаційний фонд НАН України. 2018. 246 с.

Четвертий том «Корпусна та когнітивна лінгвістика» п’ятитомної монографії «Лінгвістично-інформаційні студії» присвячено викладу теоретичних і технологічних засад корпусної лінгвістики. Особливу увагу приділено розробленню Українського національного лінгвістичного корпусу (УНЛК) та його численним застосуванням у проведенні різноманітних лінгвістичних і когнітологічних досліджень та укладанні лексикографічних праць, насамперед академічного Словника української мови в 20 томах.

Погляд на лінгвістичний корпус (ЛК) як на велику колекцію інформаційно і лінгвістично анотованих масивів природномовних текстів спонукає до розроблення структури та архітектури цих лінгвоінформаційних систем, методів ідентифікації, стандартизації та експлікації (маркування) їх структурних елементів. У цьому зв'язку окреслено роль спеціальних мов маркування (SGML, HTML, XML etc.) i різноманітних форматів подання бібліографічної та лінгвістичної інформації в технологіях побудови ЛК.

Розглянуто лінгвістичні та системотехнічні засади побудови УНЛК та його основних структурних підсистем: бібліографічної та лінгвістичної, які забезпечують індексування об'єктів зберігання, створення, редагування та оперування повнотекстовим індексом, забезпечення бібліографічного і повнотекстового багатокритеріального пошуку, статистичні та сервісні функції маніпулювання корпусними даними.

Значну увагу приділено лінгвістичним дослідженням, проведеним у Фонді на матеріалі УНЛК: вивченню різних типів омонімії лексичної системи української мови, функціонуванню прийменникових конструкцій в українських текстах, одержанню статистичних параметрів та визначенню ступеня фонетичності писемного варіанту української мови. Отримані результати мають велике значення для розроблення цифрових систем опрацювання природної мови (орфокоректори, системи семантичної інтерпретації, лінгвістичної концептографії та машинного перекладу, аналізатори та озвучувачі текстів та ін.).

Окремий розділ присвячено застосуванню корпусних технологій у сфері теорії, та технології проведення різного роду лінгвістичних експертиз природномовних текстів.

ISBN 978-966-02-8683-2

ISBN 978-966-02-8689-4 (T. 4)
(C) Український мовно-інформаційний фонд НАН України, 2018

(C) В. А. Широков та ін., 2018 
Р Озді Л 19. УКРАЇНСЬКИЙ НАЦІОНАЛЬНИЙ ЛІНГВІСТИЧНИЙ КОРПУС ............................7

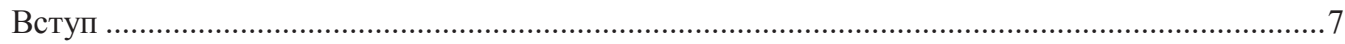

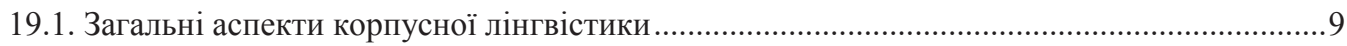

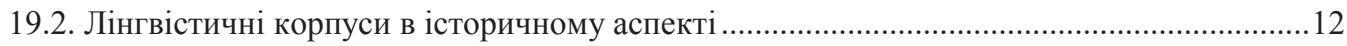

19.3. Сучасний стан розвитку корпусної лінгвістики .......................................................... 16

19.4. Маркування ЛК. Ініціатива та стандарт кодування ЛК …...........................................24

19.4.1. Історія та логіка проблеми маркування природномовних текстів ........................24

19.4.2. Принципи SGML та приклади його застосування .................................................26

19.4.3. Розвиток SGML: HTML, XML, XHTML, MathML, ChemML, UML .....................31

19.4.4. Text Encoding Initiative та Corpus Encoding Standart..............................................32

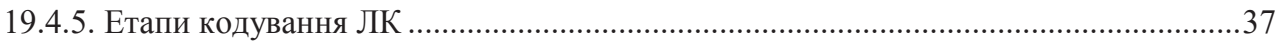

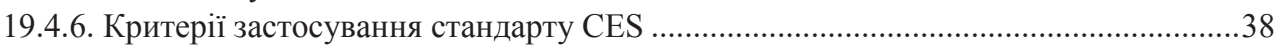

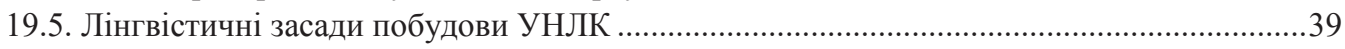

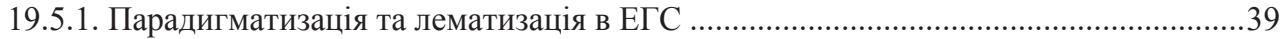

19.5.2. Моделювання системи української транскрипції................................................4

19.5.3. Моделювання фонетики української мови ...........................................................42

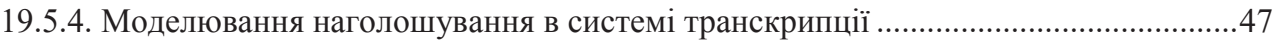

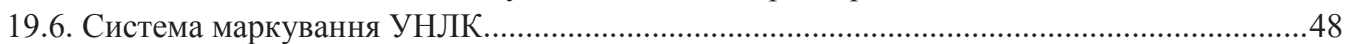

19.6.1. Бібліографічний та структурний опис документів в УНЛК .................................48

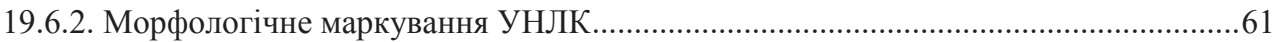

19.6.2.1. Структура бази даних ЕГС ...............................................................................62

19.6.2.2. Програмні засоби граматичної ЛБД ..................................................................6

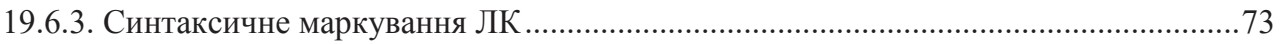

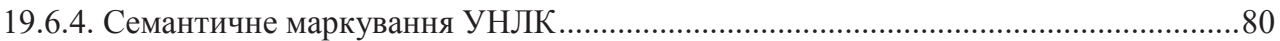

19.6.4.1. Формальні аспекти відношення синонімії та аналогія з визначенням

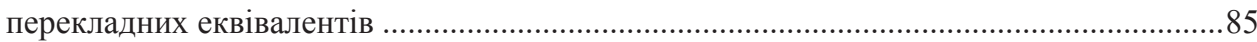

19.7. Системотехнічні та технологічні засади побудови УНЛК .............................................8 88

19.7.1. Лінгвістичний корпус як лексикографічна система ................................................8

19.7.2 Архітектура та компоненти програмного забезпечення УНЛК ............................93

19.7.2.1. Організація збереження метаданих ................................................................95

19.7.2.2. Структура БД електронної бібліотеки ...............................................................96

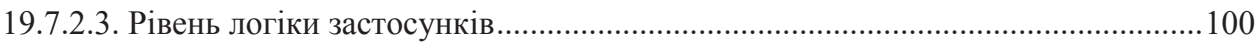

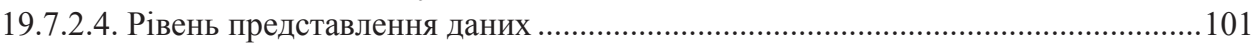

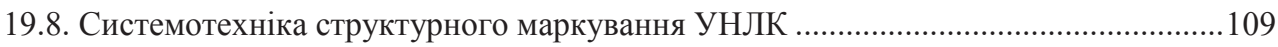

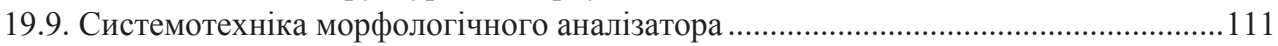

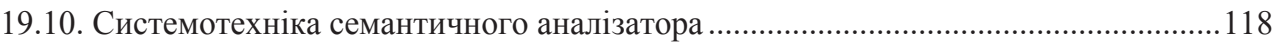

Р озділ 20. КОРПУСНІ ТА СТАТИСТИЧНІ МЕТОДИ ДОСЛІДЖЕННЯ ТЕКСТІВ....................120

20.1. Корпусні методи дослідження текстів ...................................................................... 120

20.1.1. Дослідження граматичної омонімії на морфологічно

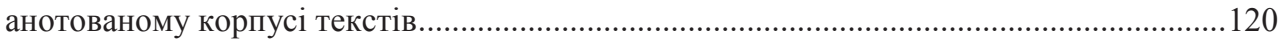

20.1.2. Визначення потенційних типів морфологічних омонімів в українській мові ....121

20.1.3. Дослідження морфологічної омонімії на матеріалі УНЛК ..................................126

20.1.4. Міжчастиномовні морфологічні омоніми в українських текстах ........................128 
20.1.5. Частота вживання ТМО в текстах

20.1.6. Характеристика ТМО за наповнюваністю їхніх ОР .........................................134

20.1.7. Лінгвістична база контекстів морфологічних омонімів........................................135

20.1.8. Дослідження функціонування українських прийменників у тексті

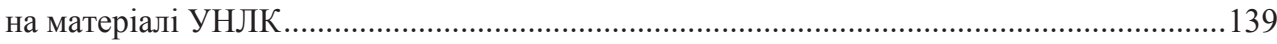

20.1.9. Дослідження функціонування прийменників на морфологічному рівні..............146

20.1.9.1. Усунення міжчастиномовної омонімії прийменників ...................................146

20.1.9.2. Ідентифікування складених прийменників у тексті ......................................151

20.1.10. Дослідження функціонування прийменників на синтаксичному рівні .............159

20.1.11. Дослідження функціонування прийменників на семантичному рівні................167

\section{Р оз діл 21. ДОСЛІДЖЕННЯ СТАТИСТИЧНИХ ПАРАМЕТРІВ} УКРАЇНСЬКОЇ МОВИ

21.1. Постановка проблеми, мета та завдання статистичного дослідження мови. Історичний огляд досліджень зі статистики мови ....

21.1.1. Апарат статистичного дослідження мови. ЛК

як експериментальна база дослідження.

21.1.2. Статистика знакової системи

21.1.3. Транскрибована форма УНЛК та дослідження відповідності

українського правопису фонетичному принципу

Р озділ 22. КОРПУСНІ ТЕХНОЛОГІї В ЛІНГВОЕКСПЕРТНІЙ ДІЯЛЬНОСТІ.

22.1. Лінгвістична експертиза: логіка проблеми

22.2. Лінгвістична експертиза: історія

22.2.1. Лінгвістична та судова лінгвістична експертизи:

подібності та відмінності

22.3. Сучасний стан розвитку галузі лінгвістичних експертиз ............................................ 199

22.3.1. Психолінгвістична судова експертиза ...........................................................200

22.3.2. Лінгвістична судова експертиза в репутаційних справах .................................201

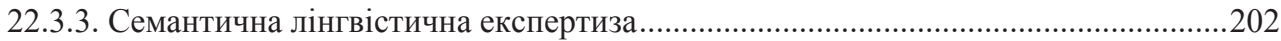

22.3.4. Лінгвістична експертиза в справах щодо введення в оману.................................203

22.3.5. Логіко-лінгвістична експертиза.....................................................................204

22.3.6. Лінгвістична експертиза законопроєктів ............................................................204

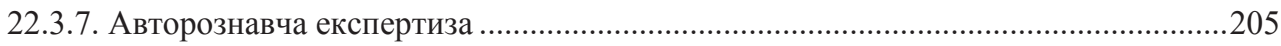

22.3.8. Лінгвістична експертиза на ознаки недоброчесного запозичення (плагіату) .....207

22.3.9. Лінгвістична експертиза на предмет пропагування наркотиків.........................209

22.3.10. Лінгвістична експертиза на предмет ознак богохульства..................................210

22.3.11. Лінгвістична експертиза на предмет прихованих мотивів ...............................210

22.4. Практичне застосування ЛК як інструменту лінгвоекспертної діяльності ...................212

22.4.1. Корпусні технології в логіко-лінгвістичних експертизах ..................................213

22.4.2. Корпусні технології в авторознавчих експертизах.............................................216

22.4.3. Корпусні технології в експертизах на предмет прихованих мотивів ...................221

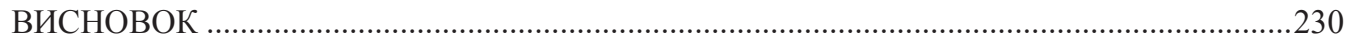

ДОДАТОК А. Лінгвоекспертна діяльність

Українського мовно-інформаційного фонду НАН України в публікаціях.

Розвиток теорії, методики та програмних засобів 


\section{РОзДІЛ 19}

\section{УКРӒ̈НСЬКИЙ НАЦІОНАЛЬНИЙ ЛІНГВІСТИЧНИЙ КОРПУС}

\section{Вступ}

В останні десятиліття великого поширення у мовознавстві набули лінгвістичні корпуси - великі колекції лінгвістично анотованих масивів природномовних текстів. У цьому зв'язку навіть виник цілий мовознавчий напрям, який одержав назву «корпусна лінгвістика». Безпосереднім наслідком впровадження лінгвістичних корпусів як провідного технологічного інструментарію сучасного мовознавчого дослідження стало розширення меж лексикографічного опису мови. Невипадково, що навіть сам лінгвістичний корпус у його найпростішому варіанті та безпосередній формі за своєю структурою нагадує певний специфічний словник, де реєстровою одиницею і водночас «лівою частиною словникової статті» виступає певна лексема, а інтерпретаційною, «правою» частиною слугує сума «мікроконтекстів», до яких входить реєстрова лексема (у всіх іï граматичних значеннях). Бажання дослідників експлікувати якомога повніше систему мовних одиниць, відношень та структур, які імпліцитно містяться в текстах корпусів, робить аналогію між лінгвістичними корпусами та лексикографічними системами - словниками, ще більш глибокою і повною. Забігаючи наперед, відзначимо, що всі лінгвістичні корпуси і насправді мають структуру певних лексикографічних систем ${ }^{1}$.

Перші корпуси текстів являли собою колекції зразків відносно невеликих розмірів. Основним об'єктом такого колекціонування був нормативний писемний варіант мови. Корпуси текстів укладались за строгою схемою, виключне значення надавалось репрезентативності масиву.

Обсяги сучасних лінгвістичних корпусів, які сягають сотень мільйонів слововживань, залучення до корпусів не тільки писемних, але й усних джерел, розширення їхніх функціональних можливостей у бік багатомовності та вдосконалення мовно-інформаційного інструментарію свідчать про фундаментальність корпусної лінгвістики як окремої ділянки науки, що намагається охопити досліджувану предметну галузь (мову) в усіх іiі проявах та повноті явищ. Адже для побудови досконалих мовно-інформаційних артефактів необхідно мати такі експериментальні масиви лінгвістичних даних, на яких у достатньо репрезентативному вигляді були б представлені всі мовні феномени. Зазначене помітно розширило сферу інтересів укладачів лінгвістичних корпусів. Деякі відомі корпуси текстів (наприклад, BNC, COBUILD / Birmingham Corpus)

\footnotetext{
${ }^{1}$ Широков В. А. Феноменологія лексикографічних систем. Київ: Наукова думка, 2004. 327 с.
} 
містять, крім писемної мови, також субкорпуси усного мовлення. Є й корпуси, укладені лише зі зразків усного мовлення (IBM-Lancaster Spoken English Corpus, Corpus of Spoken American English). Все більшу увагу розробники приділяють специфічним варіантам мови, до яких належить, наприклад, дитяча розмовна та письмова мова (корпус CHILDES), мовлення «неносіїв мови» (International Corpus of Learner English), інші різного роду підмови та ненормативні варіанти мови (сленги, девіації тощо). Ще однією тенденцією є поява так званих історичних (або діахронічних) корпусів (historical corpora), які фіксують мову на різних етапах іï розвитку (ARCHER Corpus, Helsinki Corpus, etc.) ${ }^{2}$.

Відповідно до мети укладання розрізняють лінгвістичні корпуси: синхронічні, діахронічні, розмовні, діалектні, письмової або усної форми мови, мови певних письменників, стилів або жанрів, проблемно-галузеві, фольклорні, соціолінгвістичні тощо. За лінгвістичними характеристиками корпуси поділяють на: фонетичні, орфографічні, морфологічні, синтаксичні, семантичні, одно- та багатомовні, паралельні, порівняльні та ін. Все розмаїття лінгвістичних корпусів зводиться до двох груп: загальні корпуси (що належать до мови загалом) та спеціальні (створені під конкретні дослідницькі завдання, вузькоспеціалізовані).

Із поширенням (або навіть - переважанням) цифрової форми інформації репрезентативні масиви текстів можуть бути зібраними лише у вигляді комп'ютерних БД, на матеріалі яких можна проводити різнопланові дослідження та створювати прикладні мовно-інформаційні системи. Отже, корпусна лінгвістика пов'язується із застосуванням комп'ютерних лінгвістичних корпусів як інструментів мовознавчого дослідження, що робить іiі важливою галуззю прикладної та комп’ютерної лінгвістики.

Надалі вживатимемо термін «лінгвістичний корпус» без додавання слова «комп’ютерний», а також абревіатуру ЛК.

Одним із сучасних потужних інструментів вітчизняної лексикографії та лінгвістичних досліджень $є$ Український національний лінгвістичний корпус (надалі паралельно вживатимемо абревіатуру УНЛК), опису лінгвістичних та системотехнічних принципів формування якого присвячено цей розділ. УНЛК створюється та розвивається в Українському мовно-інформаційному фонді НАН України в межах робіт із розвитку Національної словникової бази України ${ }^{3}$.

${ }^{2}$ Докладніше про розвиток корпусної лінгвістики в різних країнах див., наприклад, Biber, Douglas and Conrad, Susan and Reppen, Randi: Corpus Linguistics: Investigating Language Structure and Use. Cambridge University Press, 1998. Баранов А. Н., Добровольский Д.О. Немецкая корпусная лингвистика. Вестник МГУ. Сер. Иностранные языки. № 1, 1998. Баранов А. Н. Введение в прикладную лингвистику. Москва: Эдиториал УРСС, 2001. С. 121-128; McEnery Т., Wilson A. Corpus Linguistics: An Introduction. $2^{\text {nd }}$ Edition, Edinburgh: Edinburgh University Press, 2001. P. 20-24.

${ }^{3}$ Указ Президента України «Про розвиток Національної словникової бази» від 7 серпня 1999 року № 967/99. URL: http://zakon3.rada.gov.ua/laws/show/967/99. 


\section{1. Загальні аспекти корпусної лінгвістики}

Зміст поняття «корпусна лінгвістика» охоплює як теоретичне, так i прикладне мовознавство - напрацювання лінгвістичної теорії покладено в основу моделей та алгоритмів систем опрацювання природної мови, прикладні результати втілюються в лінгвістичні корпуси, що, в свою чергу, виступають інструментом досліджень у галузі теоретичного мовознавства. Наголошуємо, що йдеться саме про комп'ютерні корпуси, оскільки корпусами вважалися й певні традиційні паперові збірки інформації, призначені для цілей лінгвістичного дослідження (наприклад, лексичні або словникові картотеки), хоча такий напрям досліджень корпусною лінгвістикою зараз називати не прийнято. Сказане, а також потреба у створенні та практичному застосуванні в мовознавчих (і не тільки) дослідженнях комп'ютерних аналогів лексичних картотек, зрештою, спонукало до формулювання, так би мовити, рефлексивних визначень поняття лінгвістичного корпусу. Наведемо приклади найтиповіших уявлень самих представників корпусної лінгвістики, що ж таке є лінгвістичний корпус у сучасному розумінні.

Піонер корпусної лінгвістики, один з розробників Браунівського корпусу, про який йтиметься далі, В. Френсіс (William Nelson Francis) визначає лінгвістичний корпус як «зібрання текстів, яке вважається репрезентативним стосовно певної мови, діалекту або іншої ділянки мови і призначене для використання в лінгвістичних дослідженнях» ${ }^{4}$.

Сучасний російський теоретик корпусної лінгвістики, професор кафедри перекладознавства Університету Лідса (Велика Британія) С. А. Шаров наводить два підходи до визначення лінгвістичного корпусу5. Перший передбачає, що корпусом є будь-яка колекція текстів 3 певної тематики в електронній формі (Корпус 1). Інший - що корпус - це колекція текстів, зібрана у відповідності до явно сформульованих правил i, можливо, розмічена (annotated) на якомусь рівні лінгвістичного аналізу (Корпус 2). Цьому визначенню, зокрема, відповідає колекція текстів, зібраних у Машинному фонді російської мови ${ }^{6}$.

Поширеним $\epsilon$ погляд на ЛК як на репрезентативну колекцію текстів у розумінні Корпус 2, яка може адекватно представляти потенційно необмежене коло текстів фіксованого типу в певному діахронічному зрізі ${ }^{7}$. Репрезентативність у цьому визначенні передбачає, що колекція текстів є збалансованою за жанрами та функціональними стилями і що вона має достатній обсяг вибірки за кількістю

${ }^{4}$ Francis W. Language Corpora B.C. In: Jan Svartvik (ed.) Direction in Corpus Linguistics. Proceeding of Nobel-82. Stockholm, 4-8. August 1991. Berlin-New York. Mouton de Gruyter. P. 17-35.

${ }^{5}$ Шаров С. А. Представительный корпус русского языка в контексте мирового опыта. НТИ. Сер. 2. № 6. 2003. С. 9.

${ }^{6} \mathrm{URL}:$ http://cfrl.ruslang.ru/.

${ }^{7}$ McEnery T., Wilson A. Corpus Linguistics: An Introduction. $2^{\text {nd }}$ Edition, Edinburgh: Edinburgh University Press, 2001. P. 2-3. 
текстів і авторів для того, щоб слугувати основою для статистично достовірних досліджень лінгвістичних феноменів у текстах певної тематики.

Російський лінгвіст В.П.Захаров, автор низки праць 3 корпусної лінгвістики, наводить таке визначення: «Під назвою “корпус текстів” будемо розуміти великий, уніфікований, структурований, розмічений масив мовних (мовленнєвих) даних в електронному вигляді, призначений для певних цілей» ${ }^{8}$. Пізніше ним уточнено: «Під лінгвістичним корпусом текстів розуміється великий, уніфікований, структурований, розмічений, філологічно компетентний масив мовних даних, представлений в електронному вигляді й призначений для розв'язання різних лінгвістичних завдань» ${ }^{9}$. До цього визначення близьке й сформульоване школою О.С. Герда (кафедра математичної лінгвістики філологічного факультету Санкт-Петербурзького державного університету), до якої належить і В.П.Захаров: «великий за обсягом, представлений в електронному вигляді, уніфікований, структурований, розмічений і філологічно компетентний масив мовних даних, доповнений системою керування даними універсальними програмними засобами для пошуку різноманітної лінгвістичної інформації та зручного представлення іï широкому користувачеві» ${ }^{10}$.

У наведених дефініціях усі детермінанти слів «масив» та «розмітка» $€$ суттєвими і відмежовують лінгвістичний корпус від простого зібрання (колекції) електронних текстів.

Маркування лінгвістичного корпусу (розмічання, анотування, тегування (tagging) $)^{11}$ полягає в приписуванні текстам корпусу та їхнім компонентам спеціальних тегів (міток) різних типів: зовнішнього (елементи бібліографічного опису: видання, рік, автор тощо); структурного (описують структуру тексту: розділ, абзац, речення); лінгвістичного (лексикографічні, граматичні, семантичні, синтаксичні та інші параметри).

Постає питання: чи має корпусна лінгвістика якийсь окремий, специфічний, характерний саме для неї об’єкт та предмет дослідження? Це питання, власне, стосується і комп'ютерної лінгвістики загалом.

Відповідь не є однозначною. Звернімося до аналогії. Скажімо, у фізиці ділянку досліджень, які проводяться за допомогою спектроскопів, не називають «спектроскопічною фізикою», між тим як термін «спектроскопія» все-таки існує. Так само i ділянку астрономії, де дослідження проводяться за допомогою телескопів, не прийнято називати «телескопною астрономією», хоча термін

8 Захаров В. П. Чешский национальный корпус текстов: организация и способы использования. Корпусная лингвистика и лингвистические базы данных. Докл. научн. конфер. (РФ, Санкт-Петербург, 5-7 марта 2002 г.).

${ }^{9}$ Корпусная лингвистика - 2004. Международная конференция по корпусной лингвистике. URL: http://dialog-21.ru/.

${ }^{10}$ Герд А. С. Вступне слово на міжнародній конференції Корпусная лингвистика - 2004. URL: www.phil.pu.ru/news/kllbd/corpling.htm.

${ }^{11}$ Leech G. Corpus Annotation Schemes. Literary and Linguistics Computing. 1993. Vol. 8 \# 4. P. 275-281. 
«радіоастрономія» і, відповідно, ділянка астрономії, де дослідження проводяться в радіодіапазоні і за допомогою радіотелескопів, є загальноприйнятим.

Отже взагалі: чи коректно іменувати певну ділянку науки за тим експериментальним інструментарієм (об’єктом експериментальної техніки), за допомогою якого проводяться дослідження у цій ділянці? Мабуть, лише тією мірою, яка визначає, наскільки зазначений інструмент виділяє специфічний об'єкт дослідження 3-поміж усього розмаїття об'єктів цієї науки. У більш загальному розумінні відповідь лежить у площині співвідношення предмета та методу ${ }^{12}$.

3 огляду на сказане, корпусна лінгвістика не відзначається яскраво вираженим об'єктом та предметом дослідження, принаймні в області їхніх системних ознак. Те, що насправді вирізняє корпусну лінгвістику з решти галузей лінгвістичної науки, - це обсяги мовного матеріалу, який залучається до мовознавчого дослідження, комплексність, оперативність опрацювання зазначеного матеріалу та можливість прямого доступу до великого числа лінгвістичних фактів. Як буде продемонстровано далі, обсяги окремих ЛК сягають сотень мільйонів (а то й багатьох мільярдів, як, наприклад, веб-простір інформаційне наповнення мережі Інтернет) слововживань ${ }^{13}$. Такі обсяги у паперовому варіанті немислимі навіть фізично, не кажучи вже й про інші пошукові та сервісні можливості, що надають комп’ютерні інформаційні системи.

Природною ділянкою корпусної лінгвістики, безперечно, мають бути статистичні властивості мови, які проявляються лише на великих масивах текстової інформації. При цьому слід зважити на те, що саме поняття «великий обсяг інформації» не є інваріантним і дуже залежить від того, властивості яких об’єктів мовної системи вивчаються. Отже, на перший погляд, специфіка корпусної лінгвістики як окремої ділянки мовознавства може вважатися доконаним фактом лише тією мірою, якою справджується кваліфікація, що кількісні зміни у параметрах та обсягах їі об’єктів дослідження зумовлюють зміни якісні.

Проте останнє положення є занадто загальним, але як визначення - бодай часткове - певних специфічних завдань цієї ділянки мовознавчої науки виявляється не дуже складним - до них належать насамперед ті, які «вручну» виконати неможливо вже фізично, хоча їхня природа i не $\epsilon$ статистичною. Візьмімо, наприклад, таке просте i детерміністське за своєю принциповою постановкою завдання, як побудова фонетичної транскрипції для всіх українських словоформ на реєстрі, скажімо, 200 тисяч лексем, де повне число словоформ сягатиме майже чотирьох мільйонів. Виписати ці чотири мільйони слів, та ще й потім записати їх транскрипційними знаками (зрозуміло, 3 наголосами) - завдання неосяжне для традиційного, не «комп’ютерного» мовознавства. Зазначимо, що воно було

12 Декарт Р. Рассуждение о методе. Метафизические размышления. Начала философии. Луцк: Вежа, 1998. 302 с.

${ }^{13}$ Інформацію про різні ЛК, які зараз функціонують у світі, можна одержати на сайті: https://en.wikipedia.org/wiki/List_of_text_corpora. 
розв'язано комп'ютерними методами в Українському мовно-інформаційному фонді НАН України ${ }^{14}$ (далі вживатимемо скорочену назву й лише в цьому значенні Фонд). Крім того, за допомогою розвинутих в Фонді технологій було забезпечено переведення до транскрипційної форми усього діючого на сьогодні масиву УНЛК обсягом близько 200 мільйонів слів, що надало принципову можливість проведення різнопланових фундаментальних фонетичних досліджень, спрямованих на розв'язання низки прикладних задач, таких як, наприклад, побудова якісного комп'ютерного озвучувача українського тексту тощо.

Отже, завдань для корпусної лінгвістики є дуже багато, і попри видиму (i оманливу) простоту постановок деяких з них, розв’язання їх зовсім не просте. Наприклад, для побудови комп'ютерного озвучувача української мови необхідно побудувати формальну модель словозміни української мови, виділити та формально описати множину класів словозмінної парадигми української мови (цих класів на сьогодні встановлено понад 2500), розробити алгоритми та програмне забезпечення автоматичної побудови повної словозмінної парадигми за вихідною формою лексеми, вивчити, описати, типізувати й формалізувати фонетичні процеси, притаманні лексичній системі української мови та розробити відповідні алгоритми і програмні процедури для поставлення у відповідність текстовій формі слова його фонетичної транскрипції. Цього прикладу достатньо для розуміння того, як суто прикладні завдання зумовлюють для свого вирішення проведення певних лінгвістичних досліджень, що мають всі ознаки фундаментальних.

Ще яскравіше такі ознаки постають при розв'язанні, скажімо, завдання семантичного маркування ЛК, пов'язаного 3 автоматичним визначенням лексичних значень усіх наявних в ЛК слів (а також і значень наявних в ЛК фразеологізмів та інших семантико-синтаксичних структур) - завдання, яке, очевидно, тяжіє до проблематики штучного інтелекту.

\section{2. Лінгвістичні корпуси в історичному аспекті}

Ідея комп’ютерних ЛК не виникла на порожньому місці - їхніми прототипами були паперові лексичні картотеки, які вже давно слугували інструментами лінгвістичного дослідження. Обсяги найбільших з таких картотек досягають значних величин (мільйонів карток) для об'єктів, що створюються традиційними методами на паперових носіях інформації.

Власне, типова лексична картотека формувалася в такий спосіб. Спочатку мовознавець відбирав певне коло книжок (текстів), необхідних йому для проведення тих чи інших досліджень. Після цього розпочинав процес

${ }^{14}$ Див., наприклад, підсистему «Транскрипція» Інтегрованої лексикографічної системи «Словники України», версія 1.04 . 
«розписування» цих текстів на картки. Це означало, що бралась перша книжка 3 відібраної множини, перше слово з іï тексту заносилося до картки як заголовне слово картки. Під ним виписувався контекст, довжина якого вважалася достатньою для 3'ясування лексичного та граматичного значення заголовного слова. Внизу картки записувався короткий бібліографічний опис джерела, з якого бралася інформація, занесена до даної картки. Після цього весь процес повторювався $з$ другим словом цього ж тексту і так далі - аж до останнього його слова. Такому ж самому опрацюванню піддавалися й інші книжки 3 відібраної колекції. Потім усі картки розміщалися за заголовними словами в алфавітному порядку в спеціальних шафах, і це, власне, й називалось лексичною картотекою.

Описаний процес формування картотеки має назву «суцільне розписування», адже при цьому весь текст обраного джерела (всі його слова) слугували заголовними словами відповідних карток. Також використовувався метод вибіркового розписування, за яким слова разом з контекстами вибиралися за певними, встановленими дослідником критеріями.

Так, для Оксфордського тлумачного словника англійської мови за період 3 1858 по 1933 рр. було зібрано картотеку, що налічувала понад 10 млн карток ${ }^{15}$. У 1897 році німецький філолог Ф. Кюдінг (Friedrich Küding) досліджував частотність букв і буквосполучень у німецькій мові на матеріалі корпусу обсягом близько 11 млн словосполучень ${ }^{16}$, на базі якої уклав словник, що отримав його ім’я - «Частотний словник німецької мови Ф. Кюдінга» (1898). Лексична картотека Інституту української мови НАН України (за висловом керівника картотечної групи з 1987 до 2004 р. Н. М. Неровні - «рукотворна скарбниця, що має назавжди залишитися як музей української мови») ${ }^{17}$, започаткована в 1941 році, нині налічує понад 6 млн карток. На іiі основі було укладено чимало словників, у тому числі - академічний тлумачний «Словник української мови» в 11 томах $^{18}$.

Незважаючи на значний інтерес до корпусної лінгвістики та їі осяжну 3 позиції сьогодення історію, в літературі є чимало різних думок щодо іiі засад. Серед них вирізняється твердження професора лінгвістики Ланкастерського університету (Велика Британія) Т. МакЕнері (Tony McEnery), який вважає хибною думку про те, що корпуси текстів з'явилися в 1960-ті роки і отримали поширення в 1980-ті, оскільки до появи породжувальних граматик у лінгвістиці саме й домінувало вивчення масивів емпіричних даних, тобто корпусів. Інша річ, що

${ }^{15}$ Francis W. Language Corpora B.C. In: Jan Svartvik (ed.) Direction in Corpus Linguistics. Proceeding of Nobel 82. Stockholm, 4-8. August 1991. Berlin-New York. Mouton de Gruyter. P. 17-35.

${ }^{16}$ McEnery T., Wilson A. Corpus Linguistics: An Introduction. $2^{\text {nd }}$ Edition, Edinburgh: Edinburgh University Press, 2001. P. 2-3.

17 До 85-річчя лексичної картотеки / Н. Неровня // Лексикографічний бюлетень. Зб. наук. праць. Київ: Ін-т української мови НАН України. Вип. 10. 2004. С. 12-18.

${ }^{18}$ Словник української мови: в 11 тт. АН УРСР. Інститут мовознавства / за ред. І. К. Білодіда. Київ: Наукова думка, 1970-1980. 
аналіз виконувався вручну, внаслідок чого обсяг даних був обмежений. Однак ще наприкінці позаминулого століття деякі дослідники і без допомоги комп'ютера опрацьовували величезні масиви даних, про що згадувалося вище.

Розквіт породжувальної граматики i «хомськіанства» на певний час пригальмував розвиток корпусної лінгвістики. Видатний американський лінгвіст, філософ та теоретик мови Н. Хомський (Avram Noam Chomsky) піддав корпуси текстів (зауважимо - «доелектронні») різкій і багато в чому справедливій критиці: «У будь-якому корпусі природної мови існують викривлення. Деякі речення не зустрінуться, тому що вони очевидні, інші - тому що хибні, треті - тому що вони нечемні. Отже, природномовний корпус дасть настільки сильно викривлену картину, що побудований на ньому опис виявиться простим списком» ${ }^{19}$.

Н. Хомський, як послідовник раціоналізму, вважав, що дослідження емпіричних даних - абсолютно безглузде заняття, оскільки суть лінгвістики - у вивченні саме мовної компетенції (language competence), а не відображення останньої - мовної діяльності (language performance) ${ }^{20}$.

Багато мовознавців того часу (50-60-ті pp. минулого століття) також ставилися до корпусів текстів досить критично. Вони заявляли, що добре тренований лінгвіст може легко придумати сотню гарних прикладів, не звертаючись до будь-яких текстів ${ }^{21}$. А проте, корпусна лінгвістика поступово зміцнювала свої позиції й залучала все нових прибічників.

Критику Н. Хомського було враховано. При створенні електронних корпусів текстів викривлення реальної картини намагалися мінімізувати шляхом упорядкування вибірок. Але, на жаль, навіть ретельна робота над репрезентативністю вибірки залишає відкритим питання про викривлення (skewness). Незважаючи на це, можливість швидко отримувати велику кількість ілюстративного матеріалу, а також кількісну інформацію робила корпуси текстів все привабливішими для дослідників. Потужність комп'ютерів зростала, вони ставали більш ергономічними і зручними в користуванні, все більш доступними масовому користувачеві. Все більше масивів текстових даних переводилося до електронної форми, програмне забезпечення дозволяло виконувати все більш витончені операції. Кількість проєктів з використанням корпусів текстів дедалі збільшувалась ${ }^{22}$, а скептиків ставало все менше ${ }^{23}$.

${ }^{19}$ McEnery T., Wilson A. Corpus Linguistics: An Introduction. $2^{\text {nd }}$ Edition, Edinburgh: Edinburgh University Press, 2001. P. 10.

${ }^{20}$ McEnery T., Wilson A. Corpus Linguistics: An Introduction. $2^{\text {nd }}$ Edition, Edinburgh: Edinburgh University Press, 2001. Р. 5-8.

21 Див. наприклад, Фрэнсис У. Н. Проблемы формирования и машинного представления большого корпуса текстов. Новое в зарубежной лингвистике. 1988. Вып. ХІІІ. Москва: Прогресс. С. 334-353.

${ }^{22}$ Svartvik J. Corpus Linguistics Comes of Age. In: Jan Svartvik (ed.) Directions in Corpus Linguistics. Proceedings of Nobel Symposium 82. (Stockholm, $4-8$ August 1991). Berlin - New York: Mouton de Gruyter. P. 7-17. 
Зростання популярності корпусів текстів можна проілюструвати, наприклад, цитатою видатного американського лінгвіста Ч. Філлмора (Charles J. Fillmore): «Я можу зробити два зауваження. Перше полягає в тому, що я не думаю, що можуть існувати корпуси текстів, де містилася б інформація 3 усіх сфер англійського лексикону і граматики, які я хотів би дослідити, якими б великими ці корпуси не були. Друге зауваження полягає в тому, що кожен корпус, який мені доводилося вивчати, яким би малим він не був, подавав мені такі факти, які я ніколи не міг би виявити жодним іншим способом» ${ }^{24}$.

Беручи до уваги усі викладені вище думки, слід визнати, що історія корпусної лінгвістики в сучасному розумінні цього поняття налічує близько шестидесяти років. Визнано, що пальма першості у використанні комп'ютера для лінгвістичних цілей належить Центру автоматизації вивчення літературних текстів у Галараті (Італія, 1956 р.) ${ }^{25}$. Основним завданням Центру було введення до комп'ютера якомога більшої кількості текстів (причому в різній графіці) 3 метою генеральної інвентаризації різноманітних лінгвістичних фактів, а саме: морфем, графем, синтагм, частот, тобто матеріалу, який у подальшому планувалося використовувати для лінгвістичних, психолінгвістичних та інших досліджень. Галузь дослідження охоплювала дев'ять мов у чотирьох алфавітах: латина, італійська, німецька, англійська (латинська графіка); іврит, арамейська, набатійська (графіка івриту); грецька; російська (кирилиця). Планувалося, що результатом роботи Центру стане публікація різного роду покажчиків і конкордансів. Отже, за своїм підходом та цілями дослідження зазначена комп'ютерна система цілком може вважатися лінгвістичним корпусом. Назви «корпус» ця система, однак, не мала. Це пояснювалося, мабуть, тим, що у лінгвістичній традиції поняття корпусу спочатку стосувалося збірки саме друкованих (рукописних) текстів та виписаних 3 них окремих висловлень (речень), які достатньо повною мірою репрезентують ті чи інші структури певної мови, діалекту тощо.

Наскільки нам відомо, першою комп'ютерною системою, що мала у назві слово «корпус», став так званий «Браунівський корпус» (Brown Corpus, BC) ${ }^{26}$ лінгвістичний корпус стандартного американського варіанта англійської мови, робота над яким розпочалася в 1964 р. в університеті Брауна (США).

Можна вважати, що згадані два проекти започаткували напрям корпусної лінгвістики у сучасному іiі розумінні. Проте практичні можливості зазначених

${ }^{23}$ Fillmore Ch. J. «Corpus Linguistics» and «Computer-aided armchair linguistics». In: Jan Svartvik (ed.) Directions in Corpus Linguistics. Proceedings of Nobel Symposium 82. (Stockholm, 4 - 8 August 1991). Berlin - New York: Mouton de Gruyter. P. 35-61.

${ }^{24}$ Там само. С. 35.

${ }^{25}$ Про цей та інші історичні факти використання комп'ютерів у лінгвістичних дослідженнях див. Фрумкина Р. М. Автоматизация исследовательских работ в лексикологии и лексикографии. Вопросы языкознания. 1964. № 2. С. 114-119.

${ }^{26}$ The Brown Standard Corpus of American English. Brown, 1964. p. 386. 
корпусів не були значними з огляду на потужності тодішніх обчислювальних комплексів та обмеженість функцій інформаційних систем першого покоління.

Наприкінці 1960-х років було завершено роботу над іншим проєктом розпочатим ще в 1949 році корпусом текстів св. Фоми Аквінського та інших філософів середньовіччя, зібраних італійським теологом Р. Буза (Roberto Busa). Вважається, що 3 цього корпусу обсягом 10,6 млн слововживань починається традиція електронних корпусів текстів, призначених для загальних досліджень у галузі гуманітарних наук ${ }^{27}$.

\section{3. Сучасний стан розвитку корпусної лінгвістики}

На сьогодні існує багато різноманітних і потужних ЛК. Межу в 100 млн слововживань подолано вже багатьма ЛК, такими, як наприклад, Британський національний корпус (British National Corpus), Банк англійської мови (Вank of English), у зв'язку з чим можливість створення англійських ЛК обсягом 1 млрд слововживань і більше, зважаючи на домінуючі позиції англійської мови в світовій корпусній лінгвістиці, що фактично виконує роль lingua franca в багатьох галузях, постає цілком реальною, що відзначає багато дослідників ${ }^{28}$.

Водночас, в останні два десятиліття проводилась активна робота 3 укладання корпусів текстів і для інших мов - німецької, французької, іспанської, італійської, шведської, російської та ін. ${ }^{29}$

Становленню, розвитку та досягненням російської корпусної лінгвістики присвячено багато праць, на яких ми не будемо зупинятись (відсилаємо всіх, хто цікавиться цими питаннями, до праць С. О. Шарова ${ }^{30}$ та Т. І. Рєзнікової ${ }^{31}$ ). Безумовно, на сьогодні найбільшим досягненням російської корпусної лінгвістики є Національний корпус російської мови, започаткований у 2003 р. відділом корпусної лінгвістики та лінгвістичної поетики Інституту російської мови ім. В. В. Виноградова РАН. У проекті також беруть участь фахівці провідних наукових академічних установ РФ - Інституту мовознавства РАН, Інституту

${ }^{27}$ McEnery T., Wilson A. Corpus Linguistics: An Introduction. $2^{\text {nd }}$ Edition, Edinburgh: Edinburgh University Press, 2001. P. 20-21.

${ }_{28}$ Atkins B. T. S., Levin B., Zapolli A. Computational Approaches to the Lexicon: An Overview. In: B.T.S. Atkins and A. Zampolli (eds.) Computational Approaches to the Lexicon. Oxford: Oxford University Press. P. 17-48; Rundell M. The Corpus of the future, and the future of the corpus, 1996.

29 Зазначимо, що основні результати теоретичних досліджень та огляд практичних напрацювань у галузі лінгвістичних корпусів докладно представлені в колективній монографії науковців Фонду «Корпусна лінгвістика»: монографія / В. А. Широков, О.В.Бугаков, Т. О. Грязнухіна, О. М. Костишин, М. Ю. Кригін; НАН України, Укр. мов.-інформ. фонд. Київ: Довіра, 2005. 472 с., до якої відсилаємо всіх, хто цікавиться цими питаннями.

${ }^{30}$ Шаров С. А. Представительный корпус русского языка в контексте мирового опыта. НТИ. Сер. 2. Информационные процессы и системы. 2003. № 6. С. 9-17.

${ }^{31}$ Резникова Т. И. Обзор общедоступных корпусов русского языка в Интернете. НТИ. Сер. 2. Информационные процессы и системы. 2005. №3. С. 2-9. 
проблем передання інформації РАН, Всеросійського інституту наукової та технічної інформації РАН, Інституту лінгвістичних досліджень РАН, навчальних закладів - С.-Петербурзького державного університету, Казанського (Приволзького) федерального університету, Воронезького державного університету, Саратовського державного університету та наукових центрів інших країн - Білорусі, Естонії, Франції та ін. Обсяг РНЛК становить понад 600 млн слів. Типи розмітки: метатекстова, морфологічна, акцентна, словотвірносемантична.

Крім основного корпусу писемних текстів, до складу РНЛК входять субкорпуси регіональної та закордонної преси; усних текстів; акцентологічний; мультимедійний; діалектних текстів, газетний корпус 1990-2000-х рp., а також низка двомовних корпусів, однією з робочих мов яких є російська, іншими англійська, німецька, французька, іспанська, італійська, латиська, шведська, естонська, болгарська, польська, українська, білоруська, китайська, бурятська.

РНЛК доступний за посиланням: URL: www.ruscorpora.ru.

Крім вищезгаданого ресурсу, назвемо ще декілька значимих корпусів російської мови, до яких, на нашу думку, належать: Упсальський корпус, створений шведськими русистами, Машинний фонд російської мови, що створювався 3 середини 80-х рр. минулого століття під керівництвом Андрющенка В. М. та Єршова А. П. ${ }^{32}$, Гельсінкський анотований корпус російських текстів (ГАНКО) відділення слов'янських та балтійських мов та літератур Гельсінкського університету; «Тюбінгенський корпус» (Russian corpora in Tübingen) університету м. Тюбінген (Німеччина); комп'ютерний ЛК російських газет кінця XX ст. лабораторії загальної та комп'ютерної лексикології та лексикографії філологічного факультету Московського державного університету ім. М. В. Ломоносова; корпус публіцистичних текстів відділу експериментальної лексикографії Інституту російської мови ім. В. В. Виноградова $\mathrm{PAH}^{33}$; російський корпус університету м. Тампере (Фінляндія) та ін. Зауважимо, що більшість цих корпусів $\epsilon$ недоступними для широкого кола користувачів; відповідно, інформацію про їхній дослідницький потенціал та характеристики можна отримати тільки з описів, виконаних їхніми розробниками.

Українська мова поки що охоплена лише трьома лінгвістичними корпусами, доведеними до стану промислових об'єктів. Це - Браунівський корпус української мови обсягом понад 1 млн слововживань (URL: https://r2u.org.ua/corpus), Корпус текстів української мови Інституту філології КНУ імені Тараса Шевченка обсягом понад 80 млн слововживань (URL: http://www.mova.info/carticle.aspx?11=210\&DID $=5347)$ та Український національний лінгвістичний корпус (УНЛК) Українського

${ }^{32}$ Андрющенко В. М. Концепция и архитектура машинного фонда русского языка. Москва: Наука, 1989. 200 с.

${ }^{33}$ Баранов А. Н., Михайлов М. Н., Сидоров Г. О. «Динамический корпус текстов» как новая технология прикладной лингвистики. Тр. междунар. семинара по компьютерной лингвистике и ее приложениям «Диалог-98». 1998. Сер. 2. Т. 2. 
мовно-інформаційного фонду НАН України обсягом близько 200 млн слововживань.

Особливе місце в корпусній лінгвістиці посідають багатомовні лінгвістичні корпуси (multilingual corpora), порівняльні лінгвістичні корпуси (comparable corpora) ${ }^{34}$ та паралельні корпуси (parallel corpora, далі - ПЛК).

Багатомовні ЛК являють собою зібрання декількох однакових за структурою одномовних ЛК. Багатомовними також вважаються корпуси, в яких зібрано й анотовано тексти декількома мовами.

Порівняльні корпуси - це одномовні ЛК, що містять субкорпуси оригінальних та перекладених текстів. Прикладом порівняльного корпусу $є$ Савонліннський корпус текстів, зібраний в Інституті перекладачів м. Савонлінна, університет м. Йоенсуу (Фінляндія). Вмістом цього корпусу є оригінальні фінські тексти і переклади фінською мовою, виконані з англійської, російської, німецької та інших мов ${ }^{35}$.

У загальному розумінні паралельні корпуси - це ЛК з декількома робочими мовами або декількома підмовами однієї мови. Розрізняють такі підтипи паралельних корпусів: 1) тексти мовою А та їхні переклади мовою В; 2) тексти мовами А і В та їхні переклади відповідно мовами В і А (т. зв. «дзеркальні» ПЛК (reciprocal corpora)); 3) тільки перекладні тексти мовами А, В, С, ..., Х, оригінальні тексти яких були написані мовою $\mathrm{D}^{36}$. До ПЛК також відносяться діахронічні паралельні ЛК, що складаються 3 текстів різних історичних епох (наприклад, таким був би корпус давньоруських текстів та їхніх перекладів сучасною українською мовою), транскрипційні корпуси текстів, які містять тексти літературною мовою, прочитані носіями різних діалектів. До окремого підтипу паралельних ЛК відносять так звані «шумні» ПЛК (noisy parallel corpora) - 3 пропусками у перекладі, без точної відповідності між оригіналом і перекладом ${ }^{37}$.

Наведена типологія багатомовних ЛК належить британській лінгвістці М. Бейкер ${ }^{38}$ (Mona Baker).

Укажемо на певну термінологічну неузгодженість у галузі багатомовної корпусної лінгвістики, терміни якої вживаються різними дослідниками в різних значеннях. Так, нерідко терміном «порівняльний корпус» позначають те, що в

${ }^{34}$ Baker M. Corpora in translation studies: An overview and some suggestions for future research. Target 7(2), 1995. P. 223-243.

${ }^{35}$ Mauranen A. Strange things in translated language: a study of corpora. Maeve Olohan (ed.) Intercultural faultlines. Research models in translation studies. Textual and cognitive aspects. Manchester, Northampton: St. Jerome Publishing, 2000.

${ }^{36}$ Teubert W. Comparable or Parallel corpora. International Journal of Lexicography: Oxford University Press. 9(3). 1996, P. 245.

37 Див. Borin 2002: (2-5) ... and never the twain shall meet? In: Borin, Lars (ed.) Parallel Corpora, Parallel Worlds. Selected Papers from a symposium on parallel and comparable corpora at Uppsala University (Sweden, 22-23 April 1999). Amsterdam - New York, NY: Rodopi. P. 1-43.

${ }^{38}$ Baker M. (1995). 
типології М. Бейкер називається «багатомовним корпусом» ${ }^{39}$. У теорії перекладу під «паралельними текстами» часто розуміють оригінальний текст іншою мовою, близький за тематикою, структурою і жанром до тексту, що перекладається ${ }^{40}$. А відомий шведський лінгвіст Л. Борін (Lars Borin) використовує термін «паралельний корпус» (parallel corpus) стосовно будь-якого ЛК, що включає тексти різними мовами або в різних варіантах однієї мови, підтипами якого є багатомовні корпуси (multilingual corpora), корпуси перекладів (translation corpora), порівняльні корпуси (comparable corpora) та ін. ${ }^{41}$

Не слід забувати, що паралельний корпус, як і кожне велике зібрання експериментальних даних, містить помилки: невірні або неточні еквіваленти, орфографічні, пунктуаційні та стилістичні помилки, зумовлені людськими факторами, причому помилки наявні навіть у перекладах, виконаних досвідченими фахівцями. 3 цієї причини професійні перекладачі зазвичай віддають перевагу документам мовою оригіналу ${ }^{42}$.

Незважаючи на зазначені недоліки, теоретична та практична значимість багатомовних ЛК для дослідників та перекладачів-практиків є безсумнівною, вони є безцінним джерелом фактичного матеріалу як для досліджень у галузі автоматичного перекладу (верифікація систем автоматичного перекладу, формування систем «пам'яті перекладу» (translation memory), розроблення систем автоматичного пошуку перекладних еквівалентів тощо), так i для перекладознавчих досліджень (порівняння структури вихідного тексту i перекладу, визначення міри (ступеня) інформаційних втрат при перекладі, вивчення різних перекладацьких стратегій тощо).

На думку М. Бейкер, «прескриптивний пафос досліджень поступово змінюється дескриптивним. Вони (паралельні ЛК) дозволяють нам об'єктивно встановити, як перекладачі на практиці долають труднощі, і використовувати ці дані для розроблення моделей, що відповідають дійсності, для перекладачівпочатківців. Вони також відіграють важливу роль у дослідженні перекладацької норми в специфічних соціокультурних та історичних контекстах». ${ }^{43}$

Зробимо невеликий огляд досягнень європейських та світових розробників мультилінгвальних корпусних технологій.

Першими паралельними ЛК вважаються зібрані в Швейцарії тексти штормових попереджень німецькою, французькою та італійською мовами та

39 Див., наприклад, Teubert W. Comparable or Parallel corpora. International Journal of Lexicography: Oxford University Press. 9(3) 1996, Р. 238-264.

40 Див., наприклад, Алексеева И. С. Профессиональный тренинг переводчика. СанктПетербург: Союз, 2001. С 258-259.

${ }^{41}$ Borin 2002: (2-5).

${ }^{42}$ Bowker L. Towards a Methodology for Exploiting Specialized Target Language Corpora as Translation resources. International Journal of Corpus Linguistics. Amsterdam: John Benjamins. 5(1), 2000. P. 17-52.

${ }^{43}$ Baker. M. «Corpora in translation studies: An overview and some suggestions for future research». 1995. Target 7(2). P 231. 
метеорологічних прогнозів англійською та французькою, зібраних у Канаді. Попередження або прогноз як жанр документу має чіткий та лаконічний синтаксис, чим мали намір скористатися розробники, вбачаючи метою зібрання таких колекцій створення на їхньому матеріалі систем машинного перекладу ${ }^{44}$. Ресурси такого типу з'явилися наприкінці 1980-х - на початку 1990-х рр. Тоді було запроваджено низку проєктів, пов'язаних із паралельними ЛК.

Першим великим проєктом 3 укладання ПЛК вважається розпочатий в 1986 р. англо-французький паралельний корпус дебатів у канадському парламенті (Canadian Hansards English-French parallel corpus), робота над яким триває й досі. Корпус використовується при розробленні різноманітного лінгвістичного ПЗ: програм-вирівнювачів паралельних текстів (aligner) ${ }^{45}$, систем автоматичного опрацювання текстів для машинного перекладу, програм для зняття лексичної полісемії та омонімії (word sense disambiguation) ${ }^{46}$. Корпус доступний у вебі: URL: http://www.transli.com ${ }^{47}$.

Іншими значними реалізованими проєктами багатомовних ЛК $є$ : INTERSECT (International Sample of Contrastive Texts), розпочатий в Брайтонському університеті (Велика Британія) - французько-німецький ПлК ${ }^{48}$;

ET10-63 - англо-французький анотований за частинами мови ПЛК ${ }^{49}$;

CRATER (International Telecommunications Union (ITU) or CRATER Corpus) - тримовний французько-іспансько-англійський ПЛК обсягом 1 млн слововживань, зістикований на рівні речень та промаркований за частинами мови. Доступний в режимі on-line ${ }^{50}$;

Англо-норвезький ПЛК університету м. Осло (Норвегія), зістикований на рівні речень ${ }^{51}$;

Oslo Multilingual Corpus (OMC) $)^{52}$ - чотиримовний англо-норвезьконімецько-французський ПЛК ${ }^{53}$;

${ }^{44}$ Teubert W. Comparable or Parallel Corpora? International Journal of Lexicography. Vol. 9, Issue 3, September 1996, $264 \mathrm{p}$.

${ }^{45}$ Gale W. A., Church K. W. A Program for Aligning Sentences in Bilingual Corpora. Computational Linguistics, 1993. 19 (1), P. 75-102.

${ }^{46}$ Oakes M. Statistics for Corpus Linguistics: Edinburgh University Press, 1998.

${ }^{47}$ McEnery T., Wilson A. Corpus Linguistics: An Introduction. $2^{\text {nd }}$ Edition, Edinburgh: Edinburgh University Press, 2001. P. 207.

${ }^{48}$ Salkie R. 2002: How can linguistics profit from parallel corpora? In: Borin, Lars (ed.). Parallel Corpora, Parallel Worlds. Selected Papers from a symposium on parallel and comparable corpora at Uppsala University, Sweden (22 - 23 April 1999). Amsterdam - New York, NY: Rodopi. P. 93-109. URL: http://www.bton.ac.uk/edusport/languages/html/intersect.html.

49 Див. URL: http://www.comp.lancs.ac.uk/computing/research/ucrel/corpora.html.

50 Див. URL: http://www.comp.lancs.ac.uk/computing/research/ucrel/corpora.html. McEnery T., Wilson A. Corpus Linguistics: An Introduction. $2^{\text {nd }}$ Edition, Edinburgh: Edinburgh University Press, 2001. P. 207.

${ }^{51}$ Johansson, Stig 2002: Towards a miltilingual corpus for contrastive analysis and translation studies. In: Borin, Lars (ed.). Parallel Corpora, Parallel Worlds. Selected Papers from a symposium on parallel and comparable corpora at Uppsala University. (Sweden, $22-23$ April 1999). Amsterdam - New York, NY: Rodopi. P. 47-59. 
Паралельний англо-шведський корпус університетів Лунда і Гетеборга (English-Swedish Parallel Corpus (ESPC) $)^{54}$.

ETAP (Etablering och annotering av parallellcorpus för fastställande av översättningsekvivalenter: Створення та анотування паралельного корпусу для пошуку перекладних еквівалентів) - восьмимовний паралельний ЛК (шведська, арабська, англійська, фарсі, фінська, польська, сербська, іспанська) - результат співпраці Стокгольмського та Уппсальського університетів (Швеція). ${ }^{55}$.

PLUG (Parallel Corpora in Linköping, Uppsala, and Göteborg) - три зістикованих на рівні речень корпуси: шведсько-англійський, шведсько-німецький та шведсько-італійський - результат співпраці науковців Лінчепінзького, Уппсальського та Гетеборзького університетів ${ }^{56}$. ПЛК ${ }^{57}$;

COMPARA (Computational processing of Portuguese) - англо-португальський

Німецько-фінський зістикований на рівні речень ПЛК - спільний проєкт університетів Ювяскюля (Фінляндія) та Вюрцбурга (Німеччина) $)^{58}$;

Хорватсько-англійський ПЛК Загребського університету (Хорватія) ${ }^{59}$;

${ }^{52}$ URL: https://www.hf.uio.no/ilos/english/services/knowledge-resources/omc/.

53 Johansson, 2002. P. 48-49.

${ }^{54}$ Altenberg B., Aijmer K. The English-Swedish Parallel Corpus. A resource for contrastive research and translation studies. In Corpus Linguistics and linguistic theory. Papaers from the twentieth international Conference on English Language Research on Computerized corpora (ICAME 20), Freiburg im Breisgau, 1999. ed. By Christian Mair and Mariane Hundt, P. 15-33. URL: https://www.hf.uio.no/ilos/english/services/knowledge-resources/omc/enpc/.

${ }^{55}$ Borin (11) ... and never the twain shall meet? In: Borin, Lars (ed.) Parallel Corpora, Parallel Worlds. Selected Papers from a symposium on parallel and comparable corpora at Uppsala University, Sweden, 22-23 April 1999. Amsterdam - New York, NY: Rodopi. P. 12-14. URL: http://www.portugues.mct.pt/.

${ }^{56}$ Ahrenberg L., Merkel M., Sågval, Hein A, Tiedemann J. Evaluation of Word Alignment System. Proceeding of LREC-2000. Athens, 2000. Hein Anna Sågval The PLUG project: parallel corpora in Linköping, Uppsala, Göteborg: aims and achievements. In: Borin, Lars (ed.) Parallel Corpora, Parallel Worlds. Selected Papers from a symposium on parallel and comparable corpora at Uppsala University, Sweden, 22-23 April 1999. Amsterdam - New York, NY: Rodopi. P. 61-78;

Merkel, Magnus and Anderson, Mikael and Ahrenberg, Lars 2002: The PLUG Link Annotatoriterative construction of data from parallel corpora. In: Borin, Lars (ed.) Parallel Corpora, Parallel Worlds. Selected Papers from a symposium on parallel and comparable corpora at Uppsala University (Sweden, 22-23 April 1999). Amsterdam - New York, NY: Rodopi. P. 151-168; Tiedemann, Jörg 2002: Uplug - a modular corpus tool for parallel corpora. In: Borin, Lars (ed.) Parallel Corpora, Parallel Worlds. Selected Papers from a symposium on parallel and comparable corpora at Uppsala University, Sweden, 22-23 April 1999. Amsterdam - New York, NY: Rodopi. P. 181-197. URL: http://numerus.ling.uu.se/ corpora/plug/.

${ }^{57}$ Borin 2002: (11) ... and never the twain shall meet? In: Borin, Lars (ed.) Parallel Corpora, Parallel Worlds. Selected Papers from a symposium on parallel and comparable corpora at Uppsala University (Sweden, 22-23 April 1999). Amsterdam - New York, NY: Rodopi. P. 1-43. URL: http://www.portugues.mct.pt/.

${ }^{58}$ Див. Stahl, Peter 2002: Building and Processing a multilingual corpus of parallel texts. In: Borin, Lars (ed.) Parallel Corpora, Parallel Worlds. Selected Papers from a symposium on parallel and comparable corpora at Uppsala University, (Sweden, 22-23 April 1999). Amsterdam - New York, NY: Rodopi. P. 169-179; 
Англо-чеські ПЛК: Карлового університету (Прага, Чехія) ${ }^{60}$ та KACENKA (Korpus anglicko-český - elektronický nastroj Katedry anglistiky) Університету ім. Масарика (Брно, Чехія) $)^{61}$;

IJS-ELAN - зістикований на рівні речень граматично анотований словенсько-англійський ПЛК, розроблений в Департаменті технології знань Інституту Йожефа Стефана (Словенія) ${ }^{62}$;

MLCC - мультимовний ПЛК, що реалізується під егідою Асоціації ELRA (European Language Resources Association). Робочими мовами цього корпусу $\epsilon$ англійська, датська, нідерландська, французька, німецька, грецька, італійська, португальська, іспанська ${ }^{63}$.

Крім ПЛК, в яких представлено тільки європейські мови, активно розвиваються ПЛК з такими парами мов, як англійська і китайська, англійська і пенджабі ${ }^{64}$ та ін.

Цей невеликий огляд наочно демонструє інтерес до багатомовних ЛК. Але незважаючи на активність у цій галузі, до розв'язання навіть украй актуальних проблем ще досить далеко. Паралельних корпусів текстів поки що мало, їхні обсяги відносно невеликі порівняно 3 одномовними корпусами. Багато паралельних ЛК містять лише «сирі» тексти, не зістиковані навіть на рівні маркованих авторами структурних одиниць (параграфи, пункти, підпункти). Поки що представлено досить мало пар мов, причому, переважно, однією $є$ англійська. Ця обставина виглядає цілком логічно, оскільки ПЛК з робочою англійською мовою мають більшу запитаність, й отримати текстовий матеріал для них значно простіше. Однак переважання англійської мови дещо звужує можливості використання паралельних ЛК у багатомовній лексикографії.

Попри очевидні досягнення, багатотисячну армію розробників та багатомільйонну - користувачів ЛК, навколо корпусної лінгвістики та лінгвістичних корпусів досі не вщухають дискусії (на кшталт наведеної в журналі Applied Linguistics) $)^{65}$.

Так, дискутивним є питання щодо розміру зразка (прикладу), а також доцільності використання фрагментів текстів в якості матеріалу ЛК. Багато

${ }^{59}$ Tadić. M. Procedures in Building the Croatian-English Parallel Corpus. International Journal of Corpus Linguistics. Vol 6. (Special Issue) John Benjamin Publishing Company, Amsterdam/ Philadalphia, 2001. P. 107-127.

${ }^{60}$ Čmejrek M., Cuř́n J. Automatic Extraction of Teminologicae Translation Lexicon from Czech-English Parallel Texts. International Journal of Corpus Linguistics. Vol 6. (Special Issue) John Benjamin Publishing Company, Amsterdam / Philadalphia, 2001. P. 1-12.

${ }^{61}$ Див. URL: http://www.phil.muni.cz/angl/kacenka/kachna.html.

${ }^{62}$ URL: http://nl.ijs.si/elan; Erjavec, Tomaž 1999: The ELAN Slovene-English Aligned Corpus. Proceeding of the Machine Translation Summit VII. Singapore. P. 349-357.

${ }^{63}$ URL: http://catalog.elra.info/en-us/.

${ }^{64}$ McEnery T., Wilson A. Corpus Linguistics: An Introduction. $2^{\text {nd }}$ Edition, Edinburgh: Edinburgh University Press, 2001. P. 70.

${ }^{65}$ Widdowson, 2000, 2001; Stubbs, 2001; Beaugrande, 2001. 
дослідників констатують, що робота 3 фрагментами накладає певні обмеження при дослідженні тексту як єдиного цілого, зв'язності тексту тощо, а згенерований 3 фрагментарного матеріалу корпус не відповідає вимогам репрезентативності ${ }^{66}$.

Але основною причиною скептицизму, безумовно, $\epsilon$ те, що навіть найсучасніші та найпотужніші ЛК не можуть задовольнити всі інформаційні потреби користувачів через недосконале або вузькоорієнтоване лінгво-програмне забезпечення (наприклад, на сьогодні пошуковий апарат жодного ЛК не підтримує пошук за семантичними групами, граматичними формами, синтаксичними конструкціями тощо). До того ж, крім власне складання (упорядкування) ЛК, гостро стоїть і проблема маркування текстів в автоматизованому або, краще, автоматичному режимі. Немаркований корпус навряд чи можна використовувати за межами лексикографічної роботи.

Зазначимо, що розвиток інформаційно-комунікаційних технологій, особливо - хмаринних, GRID та систем опрацювання природної мови, здатних за лічені секунди опрацьовувати колосальні обсяги інформації, можна вважати, зняв будь-які обмеження на обсяги лінгвістичних корпусів - на сьогодні домінує тенденція до складання корпусів із повних текстів ${ }^{67}$. Мовно-орієнтовані інформаційні технології, бурхливий розвиток яких зумовлений комерційною значимістю будь-яких розробок в цій галузі, базуються на системотехніці ЛК, оскільки їх розроблення та тестування вимагає величезних анотованих текстових масивів. Взаємозв'язок інформаційних та корпусних технологій обумовлює їх взаєморозвиток. Орфокоректори, перекладачі, системи розпізнавання символів та ін. поставляються разом 3 текстовими процесорами, отже, встановлені на кожному пристрої, в якому передбачений природномовний інтерфейс. Тому на часі розроблення все більш досконалої та розвиненої системотехніки ЛК, розширення та вдосконалення інтелектуальних функцій комп'ютерних програм.

3 урахуванням того, що кожне нове покоління філологів все вільніше володіє комп'ютерними технологіями та методологіями дослідження, ми переконані в тому, що вже в невіддаленому майбутньому комп'ютерна лінгвістика стане провідною галуззю лінгвістичного дослідження, поза якою, мабуть, мало що залишиться.

${ }^{66}$ Baker M. Corpora in Translation Studies: an overview and some suggestion for future research target 7:2. Amsterdam: John Benjamins, 1995. P. 240.

${ }^{67}$ Див., наприклад, Biber et al, 1998. Р. 281-284. 


\section{4. Маркування ЛК. Ініціатива та стандарт кодування ЛК}

\subsection{1. Історія та логіка проблеми маркування природномовних текстів}

Лінгвістичний корпус за визначенням $є$ колекцією природномовних текстів, розмічених (промаркованих) хоча би за одним лінгвістичним параметром - ця ознака $є$ такою, що вирізняє ЛК з-поміж великого числа інших лінгвістичних інформаційно-інструментальних систем, баз даних та знань.

До системотехніки ЛК висуваються певні вимоги, зокрема, вимога уніфікованості та узгодженості 3 раніше створеними системами маркування електронних масивів інформації, що потребує переосмислення лінгвістичної інтерпретації уведених маркерів. Приблизно такими настановами керувалися організатори консорціумів TEI (Text Encoding Initiative, URL: http://www.tei-c.org/) та CES (Corpus Encoding Standard, URL: http://www.cs.vassar.edu/CES/), пропозиції та стандарти яких зараз широко застосовуються як стандарти de facto розробниками ЛК.

Для кращого зрозуміння системних принципів маркування ЛК розглянемо в історичному аспекті розвиток систем маркування, які певною мірою можна вважати прообразами та прототипами стандартів, запропонованих TEI та CES.

Історія комп’ютерного опрацювання текстів тісно пов'язана з розвитком методів та засобів їхнього відображення на зовнішніх пристроях вводу-виводу (дисплей, друкувальний пристрій тощо). Вимога представлення текстів на пристроях виводу у формі, котра повністю збігається 3 друкованою, привела до необхідності вводити до елементів внутрішнього (машинного) представлення документів спеціальні контрольні коди, які дозволяли виконувати зовнішнє відображення. Зазначені коди (перші приклади яких було запропоновано ще у 60 x роках) являли собою спеціальні позначки у машинному представленні текстів документів, наприклад, 'heading' (заголовок), 'paragraph' (розділ) тощо, за допомогою яких операторам, що вводили тексти до комп'ютера, для зручності роботи забезпечувалося виділення структурних частин тексту - фрагментів, підрозділів, розділів, глав тощо. Засобів кодування зазначеного типу було створено чимало, але єдиного підходу до маркування (хоча б на рівні структури) й кодування документів на той час ще розроблено не було.

Значний внесок у створення уніфікованої системи маркування документів було зроблено головою одного 3 комітетів асоціації Graphic Communications Association (GCA) В. Танікліфом (William Tunnicliffe). Він одним 3 перших запропонував відокремити зміст документу від його формату [Canadian Government Printing Office meeting: September 1967], виділивши в документі два основних компоненти - інформаційний та форматний. Незалежно від В. Танікліфа та майже одночасно з ним, книжковий дизайнер з Нью-Йорку С. Райс (Stanley 
Rice) запропонував ідею універсального каталогу параметризованих міток «видавничої структури» - Universal catalog of parameterized «editorial structure» tags. Директор GCA Н. Шарпф (Norman Scharpf), ознайомившись 3 ідеями та пропозиціями Райса, усвідомив їх перспективність i, базуючись на них, започаткував проєкт загального кодування (Generic Coding Project) в одному 3 комітетів GCA.

Згодом комітетом GCA було розроблено загальну концепцію кодування документів - «GenCode ${ }^{\circledR}$ concept», де було визначено, що для різних типів документів необхідні різні типи й комплекти (набори) узагальнених кодів маркування, причому передбачалася й можливість «вкладень»: невеликі за обсягом документи представлялись елементами більших. Концепція комітету GCA базувалась на таких положеннях:

- неможливо описати всю множину документів єдиним набором кодів маркування;

- мова маркування має бути описовою, а не процедурною;

- мова маркування повинна враховувати ієрархічну структуру документа.

На будь-якому документі можна справді визначити ієрархічну структуру (а також і багато інших), що зумовлює необхідність для кожного елемента введеної структури зарезервувати його індивідуальний елемент розмітки - «тег» («tag»). Кожен $з$ тегів ідентифікує певний компонент документа, в якому виконується операція маркування, причому описова мова маркування не відображає операцій, котрі необхідно виконувати з текстом (форматування, шрифтове виділення тощо), вони мають виконуватись автоматично за допомогою спеціальних програм текстового процесора або видавничої системи, які працюватимуть із вже розміченим документом. У такий спосіб досягається платформна та програмна незалежність - у будь-якому апаратно-програмному середовищі розмічені документи відображатимуться на пристроях виводу однаково. По ходу виконання проєкту загального кодування (Generic Coding Project) було організовано ще один комітет - GenCode ${ }^{\circledR}$ Committee, який у подальшому відіграв ключову роль у розвитку стандарту узагальненої мови маркування документів - SGML ${ }^{68}$, нині базового для всіх систем маркування.

Власне, історія SGML починається з 1969 року, коли Ч. Гольдфарб (Charles Goldfarb) - провідний розробник інформаційних систем корпорації IBM, займаючись як хобі автомобільним спортом, розробив оригінальну методику опису автомобільних дистанцій (легенд). Виявилося, що мова опису легенд має багато спільного з мовами програмування. Таке хобі дозволило Гольдфарбу уникнути стереотипного підходу i, займаючись розробленням системи документообігу, він спромігся запропонувати рішення, яке стало передумовою створення мов розмічання текстів. Очолюючи в компанії IBM проєкт із розроблення комп'ютерної системи обслуговування юридичних фірм, Гольдфарб

${ }^{68}$ URL: http://www.w3.org/MarkUp/SGML/. 
разом з Е. Мошером і Р. Лорі (Edward Mosher and Raymond Lorie) створили першу мову маркування документів GML (Generalized Markup Language) - систему, що дозволяла редагувати та форматувати тексти, а також здійснювати пошук у них маркованих фрагментів та оформлювати результати пошуку у вигляді окремих документів.

Власне мова GML (в назві якої, до речі, прочитуються ініціали іiі розробників) базувалася на загальних принципах кодування, запропонованих ще Райсом та Танікліфом. Але замість простої схеми маркування тут було запропоновано концепцію формально-визначеного типу документа зі складною ієрархічною структурою елементів. А саме, в GML було реалізовано концепцію типу документа - формально визначеного шаблону, що описує схему його внутрішньої будови та вкладених структур. GML не залежить ані від комп'ютерної платформи, ані від операційної системи. Ч. Гольдфарб писав: «Якщо відокремити опис документа від прикладних функцій, то з'являється можливість виділити атрибути, спільні для документів одного типу. Наявність засобів опису типу (type description) дозволяе збагатити систему опрацьовування текстів новими функціями. Мова узагальненого маркування, яка використовується для цього, допомагає зберегти всю необхідну інформацію про документ, незалежно від способу представлення цього документа та використання».

Підхід Гольдфарба до розроблення систем маркування текстів високо оцінив Американський національний інститут стандартизації (ANSI), який створив у своїй структурі спеціальний комітет - ANSI SGML, на котрий було покладено функції розробника Національного стандарту маркування на основі GML (США). Цей стандарт у подальшому отримав назву SGML - Standard Generalized Markup Language (стандартна узагальнена мова маркування). Опублікована у 1978 р. Гольдфарбом інструкція GML Markup Guide стала основним документом, яким, крім комітету ANSI SGML, керувалися також й провідні європейські розробники систем маркування, наприклад CERN ${ }^{69}$ (Conseil Européenne pour la Recherche Nucléaire).

\subsection{2. Принципи SGML та приклади його застосування}

Перший робочий варіант специфікації - проєкт стандарту SGML 3'явився у 1980 р., а вже в 1983-му Асоціація GCA за підтримки Міністерства оборони і Податкового управління США прийняла шосту робочу версію SGML як промисловий стандарт (GCA 101-1983). До розроблення нової мови маркування було залучено сотні людей з різних країн світу, що в подальшому привело до появи міжнародного стандарту ISO 8879.

${ }^{69}$ URL: http://www.cern.ch/. 
Узагальнення досвіду комп'ютерного опрацювання текстів як «ієрархій об'єктів змісту», врешті-решт дозволило формалізувати процес опису такої iєрархії згідно з принципами SGML. Основним завданням та призначенням SGML стала регламентація технології маркування тексту за посередництвом так званих SGML-елементів - тегів, що дозволяють логічно виділяти в тексті фрагменти та «об'єкти змісту». Кожному «об'єкту змісту» за набором певних правил приписується відповідний тип SGML-елементу, що також може містити додаткову інформацію у вигляді набору пойменованих атрибутів. Ha SGMLструктуру тексту накладаються обмеження: набір можливих типів SGMLелементів, їхній атрибутний склад, ієрархія та послідовність $є$ строго регламентованими. Зазначені обмеження утворюють набір правил інтерпретації SGML-тегів, що має назву DTD (Document Type Definition). Тобто, кожному тексту, розміченому SGML-тегами згідно з цим стандартом, відповідає його DTD - набір декларативних визначень із простим синтаксисом.

Для прикладу розглянемо DTD, розроблений для опису вірша Івана Франка «Розвивайся, лозо, борзо». Цей текстовий документ - вірш (poem) структурно складається з назви, строф, рядків:

\section{Розвивайся, лозо, борзо}

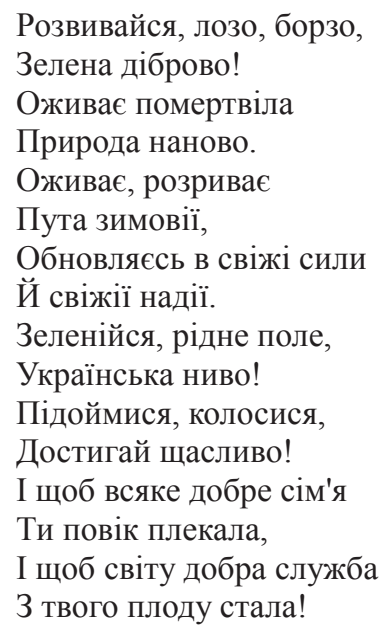

y SGML-форматі набуває наступного вигляду:

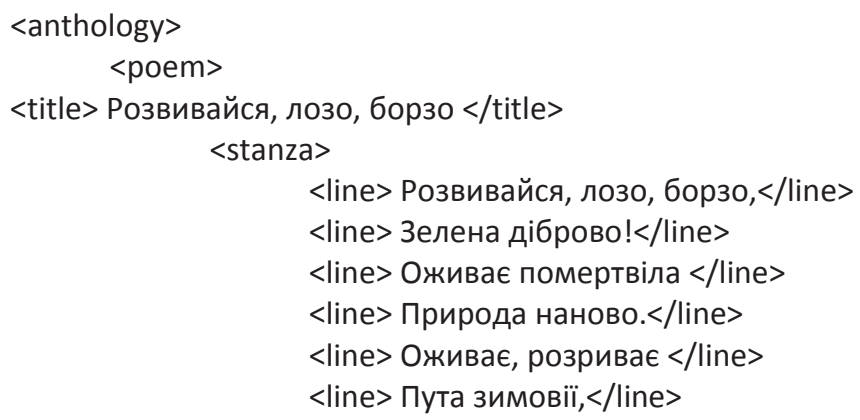




\section{<line> Обновляєсь в свіжі сили </line> \\ $<$ line> Й свіжії надії.</line> \\ $<$ stanza $>$ \\ $<$ stanza>}

<line> «Зеленійся, рідне поле,</line>

$<$ line> Українська ниво! $</$ line $>$

$<$ line> Підоймися, колосися, </line>

$<$ line> Достигай щасливо! $</$ line $>$

<line> I щоб всяке добре сім'я</line>

$<$ line> Ти повік плекала,</line>

$<$ line $>$ І щоб світу добра служба</line>

$<$ line $>3$ твого плоду стала! $<$ line>

$</$ stanza $>$

$</$ poem $>$

$<$ !-- more poems go here -->

$</$ anthology $>$

Правила, за якими виконується маркування віршів у стандарті SGML:

— anthology (збірка); може містити декілька віршів (роет);

— poem (вірш) завжди має єдиний заголовковий елемент title;

- крім заголовку (title), вірш складається зі строф (stanza);

- строфи (stanza) містять рядки (line) і кожний рядок є елементом строфи;

- за строфою може знаходитись або наступна, або кінець вірша;

- за рядком може знаходитись або наступний рядок, або початок нової строфи.

Як видно з прикладу, ідентифікатори усіх тегів взято до кутових дужок. При структурному анотуванні вірша визначено, по-перше, головний блок, виділений тегами початку $(<\ldots>)$ та кінця $(</ \ldots>)<$ anthology $></$ anthology $>$, що відображає документ (у прикладі - вірш) загалом, а також декілька вкладених до нього блоків.

Для коментарів та інших поміток у тексті документа використовуються спеціальні теги («<!» та «-->»), які програмою ігноруються.

Для наведеного прикладу, керуючись стандартом SGML, наведемо опис документа - DTD, який містить формальні визначення елементів SGML:

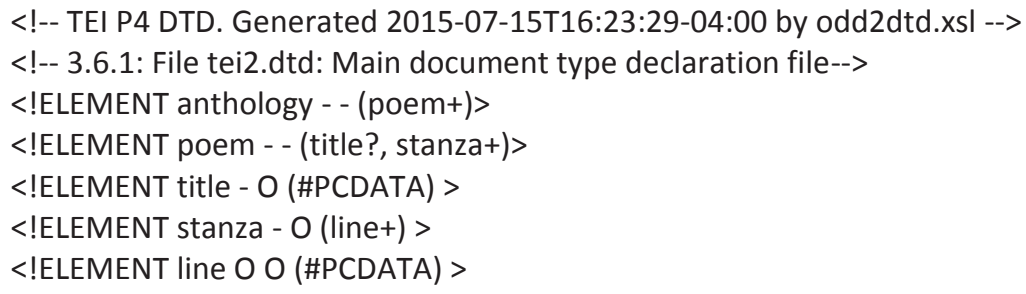

Визначення елемента, відповідно до стандарту SGML, взято у кутові дужки, а перший символ за початковою дужкою є знак оклику («!»), одразу за яким йде ключове слово, що визначає тип елемента. За ним знаходиться набір ключових слів, які визначають тип описуваного елемента. 
Ключове слово ELEMENT, з якого починається кожен з описів, означає їх належність як декларацій одного типу (у прикладі - елементи структури документа). Кожна 3 декларацій складається 3 трьох частин: 1) ім'я (група імен); 2) символи, які визначають правила мінімізування опису; 3) модель змісту. У частині «ім'я» декларації міститься загальний ідентифікатор декларованого елемента, наприклад 'poem', ‘title' тощо, причому в одному визначенні можна декларувати декілька елементів.

У частині «символи» декларації визначаються правила мінімізації описуваних нею елементів. Ці правила пояснюють, чи необхідні початкові та кінцеві теги для всіх наявних елементів, і мають форму пари символів, розділених символом пробілу. Перший 3 них визначає необхідність початкового тегу, другий - кінцевого. У загальному випадку тут ставиться або символ «-» (тег $\epsilon$ обов'язковим), або літера «О» (тег є факультативним). Як видно з наведеного прикладу, кожен з елементів документа (крім елемента $<$ line>) має початковий тег, тоді як кінцеві теги мають лише елементи < poem> та <anthology>.

Частина декларації, замкнена до дужок, називається «моделлю змісту елемента» - вона визначає, що може включати кожний елемент. Зміст елемента визначено або у термінах інших елементів, або спеціальними зарезервованими словами. У прикладі спеціальним зарезервованим словом $\epsilon$ «PCDATA» абревіатура терміну «розібрані символьні дані» (Parsed Character DATA), що позначає можливість елемента містити будь-які дані символьного типу. Якщо SGML-декларація розглядає структуру документа як родинне дерево з єдиним предком (у прикладі ним $є<$ antology $>$ ), то всі гілки цього дерева (від <antology> до $<$ poem $>$ і далі до $<$ stanza $>$, $<$ line $>$ та $<$ title $>$ ) мають тип PCDATA. У прикладі $<$ line $>$ та $<$ title $>$ визначені саме в такий спосіб.

У визначенні елемента <stanza> наявний індикатор повторення (символ «+»), необхідний для зазначення кількості входжень до нього елементів-нащадків. Синтаксис мови SGML передбачає три індикатори повторення, вони позначаються символом «+», знаком питання «?» або зірочкою «*». Перший з них («+») означає, що кількість повторень може бути більше одного; знак питання що повторень може бути не більш одного; зірочка - що зміст елемента може бути порожнім або містити повторювані дані. Так, наприклад, якщо модель змісту для елемента <stanza> визначена як (line*), зміст цього елемента може бути як порожнім, так і містити більше одного елемента типу <line>. У випадку визначення цієї моделі як (line?), порожній зміст елемента дозволено, але за наявності змісту < stanza> може містити елемент типу <line >, причому лише один. Так само з декларації елемента <poem> видно, що цей елемент може містити єдиний елемент <title> (але не обов'язково) i, крім того, повинен містити не менше, ніж один елемент $<$ stanza $>$.

Модель змісту елемента <роет> містить декілька компонентів, а саме (TITLE?, STANZA+), тому необхідно задати порядок елементів $<$ title $>$ i $<$ stanza $>$ y 
маркованому документі. Це робиться за допомогою групових об'єднувачів, яких також є три - кома «,», вертикальна лінія «|», амперсанд «\&». Груповий об'єднувач кома визначає, що елементи змісту обов'язково мають бути наявними в документі, причому в порядку, вказаному в моделі змісту. Амперсанд визначає, що компоненти обов'язково мають бути наявні у документі, але допускається їхній довільний порядок. Вертикальна лінія - що документ може містити лише один елемент. Якщо в наведеному прикладі кому змінити на амперсанд, елемент $<$ title> може розміщуватись або перед елементом <stanza> на початку блоку $<$ poem>, або після них (але не між ними). Якщо ж змінити його на «|», то документ може містити або <title>, або <stanza $>$, але не обидва одночасно.

У прикладі компонентами кожної з моделей змісту є або одиничні елементи або дані типу PCDATA. Стандартом також допускається визначення моделей змісту, компонентами яких можуть бути списки елементів, промарковані груповими об'єднувачами. Такі списки, відомі під назвою «групові моделі», можуть також бути модифіковані за допомогою індикаторів повторення й об'єднані як частини більш загальної групової моделі. Для демонстрації цих можливостей модифікуємо наведений у прикладі опис документа DTD у такий спосіб, щоб у ньому можна було зберігати вірші, що не містять строф (так звані лінійні вірші). Лінійний вірш складається з текстових рядків, отже для нього не потрібно визначати додаткові елементи - перший елемент є груповим ім'ям для всіх елементів, що відрізняються лише іменами. Це скорочує опис, оскільки не потрібно вказувати окремі декларації для кожного з елементів.

Групове ім'я є списком групових ідентифікаторів, об'єднаних довільним груповим об'єднувачем й узятим у дужки, як видно з прикладу:

<!ELEMENT (line | line1 | line2) O O (\#PCDATA) >

Визначення блоку <poem> тепер можна змінити так, щоб він включав вказані вище можливості:

<!ELEMENT poem - O (title?, (stanza+ | couplet+ | line+) ) >

Тепер цей елемент може включати назву (<title>), за якою йдуть одна або декілька строф або один чи декілька рядків. Слід підкреслити різницю між цією дефініцією та наступною:

<!ELEMENT poem - O (title?, (stanza | couplet | line)+ ) >

Тут, завдяки поширенню дії індикатора повторення на всю групу елементів, a не на кожний 3 них окремо, блок <poem> може включати елементи всіх наведених вище типів.

Аналогічним способом можна побудувати моделі, що адекватно описують структуру документів різних типів. Припустимо, що в вірші необхідно 
модифікувати структуру так, щоби крім строф до нього було включено елементи типу приспіву (як у пісні). Причому приспів може з'являтись лише на початку вірша, або як опціональний додаток після кожної строфи. Для такої структурної модифікації треба внести зміни до DTD:

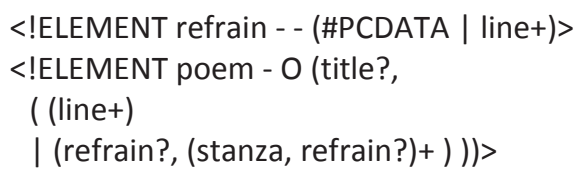

Наведений код означає, що вірш складається 3 опціональної назви (вона може бути відсутня); за нею розміщено або послідовність рядків, або неіменована група, що починається з опціонального приспіву, за якою розміщено одну або декілька інших груп - кожен член цих груп складається зі строфи та опціонального приспіву. Іншими словами, послідовність елементів типу «приспів - строфа - строфа - приспів» і «строфа - приспів - строфа - приспів» відповідають цій моделі, тоді як, наприклад, послідовності «строфа - приспів приспів - строфа» та «приспів - приспів - строфа - строфа» моделі не відповідають і тому заборонені.

Як видно з прикладу, стандарт SGML дозволяє формально визначити схему маркування в термінах елементів та їхніх атрибутів, а також правил, що керують розташуванням елементів у тексті, завдяки чому він широко використовується в індустрії опрацювання текстової інформації. Але зворотним боком універсальності цього стандарту, орієнтованого на тексти багатьох галузей, є його великий обсяг (понад 500 сторінок специфікацій), що призводить до значних ускладнень при його застосуванні для маркування великих текстових масивів.

\subsection{3. Розвиток SGML: HTML, XML, XHTML, MathML, ChemML, UML}

Для спрощення процедур анотування текстів на стандарті SGML було розроблено низку спеціалізованих мов, кожна з яких підтримує певні типи документів: HTML, XML, XHTML, MathML, CML, UML та ін. Так, мови HTML (HyperText Markup Language), XML (eXtensible Markup Language) i XHTML (eXtensible HTML) призначені для опису документів, поширюваних через World Wide Web, мова MathML (Mathematical Markup Language) - для опису та маркування документів математичного змісту, CML (Chemical Markup Language) - для відображення формул хімічних сполук та процесів.

Мова маркування HTML була запропонована сером Тімом Бернерсом-Лі та P. Кайллау (Sir Tim Berners-Lee and Robert Kaillau) для передання HTMLдокументів за допомогою НТТР-протоколу у мережі Інтернет. Саме Бернерс та Кайллау ще у 1989 році, працюючи у той час у CERNi, створили перші у світі WEB-сервер та WEB-браузер, визначили поняття універсального ідентифікатора 
ресурсів - URI та запропонували основний протокол передання даних цього типу через мережу - НТТР-протокол. Ці розробки значно прискорили розвиток Інтернету.

Звичайно, перші редакції мови HTML не містили чітких правил маркування, внаслідок чого різні браузери відображали їх по-різному. Подальша робота над стандартом HTML призвела до створення поновлених стандартів цієї мови маркування (HTML4.0, та HTML4.01), i, головне, до організації WWWконсорціуму $^{70}$ - міжнародної організації підтримки мов маркування документів, що функціонують у Всесвітній мережі. Саме WWW-консорціумом були розроблені «нащадки» мови HTML - XML та XHTML, які зараз широко вживаються не лише при оцифровуванні різнотипних текстових документів для використання їх у мережі Інтернет, але і в інших застосуваннях. Так, наприклад, консорціумом OASIS (Organization for the Advancement of Structured Information Standards $^{71}$ - Організація розвитку стандартів структурованої інформації) запропоновано й поширюється OpenDocument Format for Office Applications v1.0 (OpenDocument) - стандарт відкритих документів для офісних застосунків ${ }^{72}$. Стандарт базується на мові маркування XML й уможливлює обмін документами між офісними застосунками різних розробників (наприклад, між продуктами StarOffice 8.0 компанії Sun Microsystems, OpenOffice.Org 2.0 та Microsoft Office 12).

\subsubsection{Text Encoding Initiative ma Corpus Encoding Standart}

Відсутність універсальної системи кодування мала наслідком такі ускладнення при створенні цифрових документів та обміну ними між комп'ютерними системами 3 різними системами кодування (наприклад, для відображення кириличних символів операційними системами на платформі UNIX / Linux зазвичай використовується система кодування KOI8(r/u), операційними системами DOS/Windows - cp866/cp1251, а операційною системою Solaris компанії Sun Microsystem - ISO8859(1-15)), як:

- проблема вибору системи кодування для підготовки, опрацювання та збереження документа в цифровій формі;

— пошкодження наборів символів при обміні даними;

- необхідність створення спеціалізованих модулів для перекодування.

Тому розроблення універсальної системи кодування постало актуальним та надзвичайно значимим завданням. Утворення консорціуму Unicode ${ }^{73}$ та розроблення стандарту кодування багатомовних текстів Unicode Standard (пізніше узгодженого зі стандартом ISO 10646) призвело до створення універсальної

\footnotetext{
${ }^{70}$ URL: http://www.w3c.org.

${ }^{71}$ URL: http://www.oasis-open.org/home/index.php.

${ }^{72}$ URL: http://www.oasis-open.org/committees/download.php/12572/OpenDocument-v1.0-os.pdf.

${ }^{73}$ URL: http://www.unicode.org/.
} 
системи кодування. Оскільки більшість сучасних комп'ютерних систем підтримують стандарт Unicode / ISO 10646, це значно спростило міжсистемний обмін документами у цифровій формі.

У 1999 році Асоціацією з комп’ютерів та гуманітарних наук (Association for Computers and the Humanities), Асоціацією обчислювальної лінгвістики (Association for Computational Linguistics) та Асоціацією комп'ютерних технологій в літературі та лінгвістиці (Association for Literary and Linguistic Computing), 3 метою стандартизації цифрових документів та методів обміну ними між різноплатформенними комп'ютерними системами, було сформульовано базові принципи TEI (Text Encoding Initiative) та опубліковано «Принципи кодування й обміну електронними текстами» (Guidelines for Electronic Text Encoding and Interchange ${ }^{74}$ ). До проєкту було залучено декілька сотень вчених різних спеціальностей з усього світу. Деякі дослідники вважають, що розроблення ТЕI уможливила перетворення «просто» текстів на багатогранне середовище для роздумів про технологію, лінгвістичні аспекти текстів тощо.

Принципи та рекомендації ТЕІ стосуються:

— правил формування заголовка ТЕІ-документа, а саме: елементів, що мають бути включеними до заголовка документа (опис файлу, у якому розміщено документ (<fileDesc>), повний бібліографічний опис вихідного документа, опис кодування документа (<encodingDesc>), опис типу документа (<profileDesc>), що містить детальну інформацію стосовно небібліографічних аспектів тексту (мови та підмови, що в ньому використовуються, обставини створення, учасники створення та ін.);

- списку всіх елементів, що можуть бути наявними в ТЕІ-документах;

- базової структури тексту;

- опису базового набору тегів для розмічання поезіі;

- опису базового набору тегів для розмічання прози;

- опису базового набору тегів для розмічання сценаріїв, вистав, радіопередач тощо;

— відображення та базового набору транскрипційних символів мовлення, що можуть включати, крім стандартних символів транскрипції, паузи та звукові, але нелексичні явища - сміх, кашель, тощо;

- принципів розмічання одномовних та багатомовних словників; структури словникових статей, заголовних слів та вимови слів;

- створення термінологічних БД у відповідності до стандартів ISO CD 16642, ТМF: Terminological Markup Framework;

- засад об'єднання елементів та принципів міжелементних посилань у нелінійних документах або документах з неієрархічною структурою;

- механізмів аналізу документів, що передбачає їх розбиття на типові лінгвістичні об'єкти - речення, слова, морфеми тощо;

\footnotetext{
${ }^{74}$ URL: http://projects.oucs.ox.ac.uk/teiweb/P4X/driver.pdf.
} 
— опису базових властивостей документа в окремому файлі для полегшення отримання цієї інформації.

Рекомендації TEI спрямовано на створення нових ресурсів та обмін існуючими. Хоча основна увага при розробленні мовно-орієнтованої системи приділяється кодуванню природномовної інформації, зрозуміло, що для інших форм представлення інформації (графічних зображень, звукової інформації і т.д.) також мають передбачатися засоби кодування. Для визначення схем їхнього кодування в «Принципах ТЕI» в якості базової схеми використовується стандартна мова узагальненого маркування SGML, що є свідченням їі гнучкості та універсальності. На сьогодні всі програмні продукти, орієнтовані на SGML / XML-сумісні документи, можуть працювати з текстами, побудованими за принципами TEI.

Головною метою розробників «Принципів» було визначення стандартів представлення документів у SGML-форматі 3 урахуванням усіх їхніх компонентів - бібліографічного опису, мови, структури тексту, лінгвістичних параметрів тощо. Причому розробниками було розглянуто не лише правила створення стандартизованих SGML / XML документів, але й принципи укладання коректних описів цих документів - файлів DTD, без яких, як вже зазначалось, коректна робота 3 цими документами неможлива. Зазначимо, що в останній редакції «Принципів» (TEI P4), у порівнянні з першою, більше уваги приділено розробленню та стандартизації DTD для XML-представлення документів, що пояснюється фактом широкого розповсюдження мови XML, відповідно, поширенням систем опрацювання XML-документів - як комерційних, так i 3 відкритим кодом.

Основні розділи «Принципів» розглядають такі аспекти створення цифрових документів та роботи з ними:

- базову структуру TEI DTD, що обов'язково повинна включати ядро опису документа (core tag sets), яке є стандартним компонентом основного TEI DTD в усіх його формах. Цей компонент включається до опису документа автоматично. Крім того, до структури TEI DTD входять базові описи документа TEI (base tag sets), що являють собою основні блоки для кодування текстів різноманітного типу та додаткові елементи TEI (additional tag sets) для опису специфічних документів;

- правила кодування різних мов та набори символів, які при цьому використовуються. У сучасних комп'ютерних системах для кодування символів використовується багато систем. До них слід віднести одну з найбільш ранніх ASCII (American Standard Code for Information Interchange), яка «працює» лише 3 набором стандартних символів англійської мови, ANSI (American National Standard Institution), що «працює» 3 європейськими мовами, базованими на латинському алфавіті, ISO-8859 (1-15) - кодування, стандартизоване 
Міжнародною організацією стандартів, що дозволяє працювати також зі східноєвропейськими мовами, базованими на кириличному письмі.

Рекомендації ТЕІ відіграли важливу роль у розвитку корпусної лінгвістики. 3 накопиченням досвіду лінгвістичних досліджень перед розробниками постали принципово нові завдання, що зумовили необхідність змін, адаптації та розвитку існуючих стандартів опрацювання природномовної інформації. Нині консорціум TEI об'єднує 93 учасники з багатьох країн світу. Одним з учасників TEI $\epsilon$ Український мовно-інформаційний фонд НАН України - єдиний не тільки 3 України, а й узагалі з пострадянських країн.

Інтерес до зазначеної проблематики спонукав розробників потужних корпусних проєктів, таких як MULTEXT (LRE) ${ }^{75}$, EAGLES $^{76}$, Vassar / CNRS та ін. ініціювати створення Corpus Encoding Standard ${ }^{77}$ - CES, що максимально відповідає потребам, які виникають при дослідженні мов та створенні прикладних програм, орієнтованих на опрацювання великих обсягів природномовної інформації. Загальною метою створення цього стандарту $\epsilon$ визначення мінімального рівня кодування, який повинен мати ЛК. Стандарт покликаний забезпечити представлення ЛК у вигляді, максимально придатному для розроблення різноманітного програмного забезпечення (ПЗ), автоматичного створення лінгвістичних анотацій, проведення лінгвістичних досліджень та ін.

Розглянемо загальні положення та принципи цього стандарту.

CES є підмножиною SGML, тобто схема кодування CES здійснюється в термінах SGML-елементів та атрибутів. Як зазначалося, стандарти TEI розроблені 3 урахуванням максимальної узагальненості та гнучкості, що зумовило їхній досить великий обсяг. CES, будучи підмножиною стандарту TEI, застосовується саме для кодування ЛК. Практичний досвід, набутий при використанні ЛК для прикладних досліджень, показав необхідність вдосконалення стандартів маркування текстів, що вимагало виходу за межі мінімальних вимог ТЕI. Взяти до уваги хоча б той факт, що на сьогодні текстові масиви існують у будь-якому текстовому форматі, призначеному в основному для друку, а перетворення їх у зручні для використання представлення вимагає спеціального підходу. Саме це й привело до появи в останній редакції стандарту TЕI додаткових правил, необхідних для коректного маркування текстів ЛК.

Стандарт CES розрахований на використання як в одномовних ЛК, так і в багатомовних, що складаються 3 текстів декількома мовами, як, наприклад, MULTEXT $(\mathrm{LRE})^{78}$. Останні ЛК виступають ресурсами та інструментами масштабних лексикографічних та лінгвістичних досліджень, спрямованих на вивчення реальних мовних фактів 3 метою створення граматик, словників, лінгвістичних аналізаторів, систем машинного перекладу та ін.

\footnotetext{
${ }^{75}$ URL: https://www.issco.unige.ch/en/research/projects/MULTEXT.html.

76 URL: http://www.ilc.pi.cnr.it/EAGLES/intro.html.

${ }^{77}$ Corpus Encoding Standard: URL: http://www.cs.vassar.edu/CES/index.html.

${ }^{78}$ URL: https://www.issco.unige.ch/en/research/projects/MULTEXT.html.
} 
CES орієнтовано на виділення об'єктів, що використовуються для проведення лінгвістичних досліджень та розроблення корпусно-орієнтованих застосунків. Йдеться про такі об’єкти, як параграф, розділ, заголовки, посилання, речення, цитати 3 діалогів, назви, дати, абревіатури, терміни тощо. Стандарт також охоплює лінгвістичні анотації текстів (зокрема, морфологічне маркування, вирівнювання паралельних текстів, транскрибування тощо).

Виділення інтерпретаційної частини тексту у стандарті CES здійснюється за допомогою розширення текстової послідовності певними тегами. При цьому прийнято наступну узагальнену схему опису:

$<$ tag $>$

опис змісту елементу

attribute1

опис першого атрибута

value 1 - перший допустимий атрибут

value 2* - другий допустимий атрибут

(* вказує значення за замовчуванням)

$</$ tag $>$

Схема маркування CES презентується трійкою елементів: 1) множиною допустимих символів; 2) синтаксичними та 3) семантичними правилами виділення інтерпретаційної частини. Під поняттям «метамова маркування» розуміється набір правил, що формально описують форми синтаксичних правил схеми маркування. Семантичні правила, зазвичай, у схемі маркування не $\epsilon$ формалізованими, оскільки семантика переважно визначається на підставі загальноприйнятих уявлень.

У CES прийнято розподіл вмісту бази даних ЛК на три категорії: 1) документація; 2) первинні дані; 3) дані лінгвістичної анотації.

Документація включає в себе загальну інформацію стосовно тексту, його змісту та принципів кодування. Зокрема, до неї відносяться: бібліографічний опис, набори символів та об’єктів, опис прийнятих угод про кодування.

Первинні дані - це текст у цифровому вигляді. В первинних даних розрізняють два типи інформації: 1) великі структури, що включають універсальні текстові елементи (том, розділ і т.ін. до рівня параграфа), а також посилання, назви, таблиці, рисунки, графіку тощо; 2) структури типу «підпараграф», до яких включаються елементи, що деталізують великі структури (наприклад, речення, цитати, слова, скорочення, назви, дати тощо).

Дані лінгвістичної анотації генеруються та додаються до первинних даних за результатами лінгвістичних досліджень, зазвичай, на рівні підпараграфів. Прикладом даних лінгвістичної анотації $є$ інформація, що стосується вирівнювання паралельних текстів, морфологічна та синтаксична інформація та ін.

3 огляду на категорії інформації, що виділяють в текстах ЛК, CES передбачає: 
- набір стандартів рівня метамови (особливості використання SGML, набори символів та ін.);

- набір тегів та рекомендації для створення документацій;

— набір тегів та рекомендації для кодування первинних даних;

— набір тегів і рекомендації для формування лінгвістичних анотацій.

\subsection{5. Етапи кодування ЛК}

CES забезпечує кодування даних різних рівнів. Перший етап кодування забезпечує необхідний мінімум для використання ЛК у прикладних програмах, наступні - передбачають розширення обсягів кодованої інформації для підвищення точності ідентифікації текстових елементів. Зауважимо, що складність методів комп'ютерного маркування зростає з кожним рівнем, що істотно збільшує трудовитрати на їх реалізацію. Розрізняють три рівні стандартизації: 1) рівень метамови; 2) синтаксичний; 3) семантичний. Кожен наступний рівень містить більш детальне маркування, що спирається на маркування попереднього рівня, тобто рівні стандартизації мають чіткий ієрархічний зв'язок - прийняті умовності на одному рівні впливають на те, що може бути зроблене на наступному.

Рівень метамови. Стандартизація на рівні метамови регламентує форму синтаксичних правил й основних механізмів схем маркування. На цьому рівні визначаються внутрішні атрибути тегів, базові набори символів, правила присвоєння імен, зарезервовані слова, допустимі відхилення (наприклад, випущення кінцевих тегів тощо) відповідно до SGML-стандарту.

Синтаксичний рівень. Стандартизація на синтаксичному рівні полягає у визначенні елементів синтаксичного рівня текстів корпусу, відповідних тегів та формальних правил їх застосування (наприклад, тип даних, з якими може бути пов'язаний тег і т.ін.). Особливість цього рівня полягає в існуванні формального способу перевірки відповідності синтаксичної розмітки вихідному тексту, потреба в якому виникає у разі неоднозначності (тим самим тегом позначено різні об'єкти синтаксичного рівня в допустимому синтаксичному контексті). Тобто кодування на синтаксичному рівні не гарантує інваріантного зв'язку тегів 3 об'єктами синтаксичного рівня. Більш відчутним цей недолік стає в процесі обміну корпусами, злитті, доповненні.

Семантичний рівень. Стандартизація на семантичному рівні вимагає більш точних визначень та зв'язків зі змістом тегу. CES призначений для стандартизації на семантичному рівні лінгвістичних елементів для їх використання у технічних застосунках, але не завжди можливо установити формальні ознаки для визначення тегів семантичного рівня. Семантичне маркування переважно орієнтоване на користувача, що самостійно має визначати належність частини тексту до певного тегу. Наприклад, тег <назва> ймовірно використовується, щоби виділити частину 
тексту, яка більш-менш підходить до визначення <назва>. Стандартизація на семантичному рівні досягається дотриманням рекомендацій, наведених у довідниках користувача, що не завжди витримується.

\subsection{6. Критерії застосування стандарту CES}

Достатність. Набір структурних елементів повинен бути достатньо широким, щоби задовільнити якомога більше вимог. Водночас бажано, щоби схема маркування не містила надлишкової інформації - адже більш проста схема зручніша для розуміння та використання. Тому стандарт CES розроблено так, аби включати мінімальний, але достатній набір елементів.

Несуперечливість. Схема маркування повинна грунтуватися на несуперечливих правилах, які би дозволяли однозначно визначати належність об'єктів до тегів або атрибутів, вміст тегу та ін. Продумана базова система однозначних правил гарантує цілісність та когерентність схеми маркування, створює базу для iii розвитку. Дотримання критерію несуперечливості полегшує переведення тексту в інші формати. Навпаки, відсутність такої базової системи, різні стилі кодування в одному корпусі призводять до проблем при опрацюванні промаркованого тексту (ускладнює перевірку коректності тегів, проведення пошуку та ін.)

Biдmворюваність. При кодуванні важливо закладати можливість відокремлювання вихідного тексту від внесених міток та іншої доданої інформації. Тому схема кодування повинна базуватися на чітко визначених правилах, що дозволяють відтворювати вихідний текст за допомогою простих алгоритмів.

Як показує практика, кількість похибок при використанні алгоритмів, що вимагають перенесення, відображення або випущення (невідображення) тегів, менша, ніж при використанні контекстно-залежних алгоритмів, або алгоритмів, що реконструюють послідовність елементів.

Коректність. Коректність означає відповідність назв тегів, правильності вкладеності, порядку слідування, наявності всіх необхідних тегів у документах їхнім структурним специфікаціям.

Перевірка на коректність здійснюється за допомогою спеціального ПЗ та відіграє вагому роль у зменшенні похибок. Розробники завжди балансують між здійсненністю перевірки на коректність i прагненням до узагальнення та спрощення схеми. Наприклад, використання загального тегу < div> для ієрархічного розподілу тексту виключає можливість перевірки ієрархії на правильність.

Можливість збору даних. Збір даних включає накопичення та кодування даних за допомогою ручного вводу або з використанням програми розпізнавання тексту. Автоматичне розпізнавання на сучасному етапі розвитку мовно- 
орієнтованих технологій поки недосяжне, тому розпізнавання великих текстових масивів проводиться в автоматизованому режимі, що вимагає значних трудовитрат на постредагування.

Технологічність. CES враховує потреби, пов'язані 3 автоматичним опрацюванням текстів (вибір тексту відповідно до заданих (встановлених) критерієв, визначення типу міжтекстових покажчиків, використання спеціальних механізмів, об'єднання текстів або інших елементів корпусу). Хоча загальний стандарт кодування в принципі забезпечує обмін даними, розробники часто віддають перевагу локально розробленим схемам кодування.

Масштабованість. Через неможливість створення схеми кодування як абсолютно завершеного програмного продукту, важливо передбачати її розвиток. Вище згадувалася проблема досягнення балансу між узагальненням схеми та здійсненністю перевірки на коректність, але на останню також може вплинути й масштабованість, що мають враховувати розробники.

Компактність. Маркування істотно (приблизно на порядок) збільшує розмір файлу, що неприйнятно знижує швидкість опрацювання промаркованого текстового масиву. Можливими шляхами досягнення компактності є: зменшення кількості атрибутів в елементах; застосування специфічних кінцевих тегів елементів або відмова від них; використання XML-схеми маркування та ін.

Будь-який 3 цих шляхів має свої переваги та недоліки. Наприклад, мінімізування тегів або відмова від кінцевих тегів може призвести до необхідності розроблення спеціального ПЗ, тому мінімізування як шлях досягнення компактності проводиться 3 урахуванням його доцільності та обчислювальної потужності комп'ютерної системи.

Зрозумілість. Розмічений текст зазвичай використовується зі спеціальним програмним супроводом, призначеним для забезпечення розбірливості, безпосередньо пов'язаної зі зрозумілістю. Але можлива ситуація, що таке Пз не повністю відповідає вимогам користувача, що спричиняє необхідність залучення IT-фахівців до розбору тексту.

Конкретні приклади застосування мов маркування, ідеології TEI та CES до побудови DTD та тегсетів (системи тегів) наводяться в наступних підрозділах.

\section{5. Лінгвістичні засади побудови УНЛК}

\subsection{1. Парадигматизація та лематизація в ЕГС}

Комбінація різних параметрів визначає словозмінний парадигматичний клас (СПК), тобто параметризує множину граматичних станів лексем, тотожних відносно системи словозміни. Отже, належність, наприклад, двох лексем до того ж самого СПК означає, що будь-яка словоформа однієї лексеми відрізняється від словоформи іншої лексеми з такими самими граматичними параметрами лише 
своєю незмінною частиною. Використання набору алгоритмів дозволяє здійснювати граматичну ідентифікацію лексеми, тобто розбиття реєстрового ряду словника за словозмінними парадигматичними класами. Наприклад, у чинному варіанті електронного граматичного словника (ЕГС) СПК № 1592 включає лише дві лексеми: «Великдень» i «переддень», тоді як СПК № 2302 (прикметники твердої групи без особливостей в узгодженні) включає 18451 лексему. Аналіз лексичної системи української мови на масиві понад 200 тис. реєстрових одиниць дозволив виокремити 2563 словозмінних класи, 3 яких приблизно половина припадає на дієслівні.

Створений у Фонді ЕГС побудовано на основі граматичної БД української мови, де узагальнено матеріали новітніх академічних словників. Його реєстр налічує 261 тис. одиниць. В ЕГС експліковано такі характеристики: вихідна форма слова; належність до омонімічного ряду; частина мови; рід (для іменників та прикметників); вид (для дієслів); парадигматичний (словозмінний) i акцентуаційний клас; повна словозмінна парадигма 3 позначенням наголосів для кожної словоформи; а також додаткові характеристики слова: обмеженість вживання (діалектизм, просторічне, архаїзм), стисле тлумачення значення для омонімів та рідковживаних слів, джерело, рік включення слова в реєстр та ін.

Кожній реєстровій одиниці ЕГС автоматично ставиться у відповідність іiі СПК, словозмінна парадигма, фонетична транскрипція та наголос відповідно до Орфографічного словника української мови ${ }^{79}$. Для розставлення наголосів у Фонді було розроблено акцентуаційну класифікацію, яка ставить у відповідність слову схему наголошення у похідних словоформах.

Акцентуаційна класифікація передбачає й специфічні схеми наголошення. Наприклад, у 90 \% лексем масиву обсягом 260 тисяч реєстрових одиниць зсув позиції наголосів у похідних словоформах не відбувається (такі лексеми відносять до нульового класу). Але в решти 25 тисяч лексем мають місце зсуви позиції наголосу. Так, акцентуаційний клас, якому в системі ЕГС позначається як «клас 1», охоплює дієслова на -увати з наголосом на суфіксі -ува́ти (напр., абеткува́ти). Тоді як дієслова 3 наголосом на -юва́mu, у разі наявності в парадигмі пасивного дієприкметника (малюва́ти - мальо́ваний), потрапляють в інший клас через зсув у цьому граматичному значенні на 1 символ ліворуч (для класу 1 цей зсув складає -2). Загалом виділено 691 акцентуаційний клас. Коректність розставляння наголосів у словоформах ЕГС (що означає, наприклад, відсутність наголосів на приголосних, дефісах тощо) перевіряється автоматично.

У режимі «Транскрипція» на екран виводиться фонетична транскрипція усіх словоформ 3 візуалізацією основних i другорядних наголосів. Так, у слові

${ }^{79}$ Орфографічний Словник української мови. «Словнки України». Вид. 2-е, випр. та доп. Київ: Довіра, 1999. 989 с. «Словники України». Український орфографічний словник. Видання 4-те. / за ред. В. М. Русанівського. Київ: Довіра, 2005. 1069 с. 
гря̀зеглѝноторрфолікува́ння вказується три додаткових наголоси (нахилена вліво рисочка над голосною).

ЕГС дозволяє здійснювати пошук слова за маскою, формувати вибірку слів певної частини мови або парадигматичного класу, омонімів, незмінних слів, власних імен. Реєстр може виводитися на екран в абетковому або інверсійному порядку. Застосування SQL-запитів до БД граматичного словника дозволяє формувати й більш складні вибірки.

Підсистема ведення i актуалізації граматичного словника дозволяє переносити лексему до іншого парадигматичного або акцентуаційного класу в разі неточності в парадигмі або зміни правопису, створювати нові парадигматичні класи або корегувати існуючі. Також є можливість зміни статусу лексем в ЕГС, фіксуючи їх як активні, неактивні, вилучені. На сьогодні ЕГС нараховує 553293 лексеми, в тому числі створені за словозмінними моделями, але не зафіксовані в словниках (такі лексеми позначаються як неактивні). Загалом в ЕГС нараховується 232750 активних лексем.

ЕГС $є$ інструментом укладання тлумачного академічного 20-томного Словника української мови, використовується в роботі над перевиданням Українського орфографічного словника та версій інтегрованої лексикографічної системи (ІЛС) «Словники України», для укладання інших словників, а також як користувацька прикладна система для ведення граматичної БД УНЛК. Крім того, ЕГС може бути використаний як модель для укладення граматичних словників інших мов. Зокрема, за такою ж моделлю було створено російський ЕГС та ведеться робота над створенням англійського, французького, німецького, іспанського та турецького електронних граматичних словників. Подальший розвиток системи йде в напрямку візуалізації граматичних параметрів, параметризації лексики на основі частотності словоформ для зняття граматичної i лексичної омонімії, а також лексикографування інших аспектів лексикограматичного значення.

\subsection{2. Моделювання системи української транскрипції}

Функція «Транскрипція» в системі маркування УНЛК забезпечує виведення на екран фонетичного відображення вимови лексем та словосполучень транскрипційними знаками.

Програмну реалізацію функції «Транскрипція» виконано на основі Орфоепічного словника української мови в 2-х т. за ред. М.М.Пещак, В. М. Русанівського, що вийшов у серії «Словники України» видавництва «Довіра» в 2001 р. (Том 1) та 2003 р. (Том 2).

Орфоепічні правила, за якими автоматично будується транскрипція, розроблені відповідно до вимог літературної вимови звуків, сформульованих в Українському правописі (1993), колективній монографії «Історія української 
мови. Фонетика» (1979) (укладачі - М. А. Жовтобрюх, В. М. Русанівський, В.Г. Скляренко) та посібнику «Сучасна українська літературна мова. Морфологія» (1969) (відповідальний редактор В. М. Русанівський).

Переведення правописних правил в орфоепічні грунтується на встановленні відповідності транскрипційних знаків алфавітним літерам. Пор.:

\begin{tabular}{|c|c|c|c|c|c|c|c|c|c|c|c|c|c|c|c|c|c|c|c|c|}
\hline $\begin{array}{l}\text { алфавітні } \\
\text { літери }\end{array}$ & б & B & $\boldsymbol{\Gamma}$ & I & д & Ж & 3 & К & Л & $\mathbf{M}$ & H & II & $\mathbf{p}$ & c & $\mathbf{T}$ & $\phi$ & $\mathbf{x}$ & Ц & $\mathbf{Y}$ & III \\
\hline $\begin{array}{l}\text { транскрипці } \\
\text { йні знаки }\end{array}$ & б & B & $\boldsymbol{\Gamma}$ & I & д & ж & 3 & К & Л & $\mathbf{M}$ & H & II & $\mathbf{p}$ & c & $\mathbf{T}$ & $\phi$ & $\mathbf{x}$ & Ц & प & III \\
\hline
\end{tabular}

Наведені транскрипційні знаки вживаються для позначення твердих приголосних, неважко переконатися, що вони збігаються з відповідними літерами. Але якщо ці приголосні в певних позиціях вимовляються м'яко чи пом'якшено, в транскрипції за ними згори дається вертикальна рисочка (н', 3'), якщо ж напівпом'якшено - за ними ставиться перевернута догори кома $\left(\boldsymbol{\sigma}^{6}, \boldsymbol{ж}^{\mathbf{6}}\right)$.

Літера в у кінці слів і складів в сучасній українській літературній мові вимовляється як нескладове у і транскрипційно позначається знаком ў: ма́впа [ма́ўпа], за́сув - [за́суў]. Як нескладове у ця літера вимовляється і транскрипційно позначається знаком ў на початку слів [вона́ ўсезна́йка] та в ролі прийменника [зайди́ ў ха́ту].

Літери $\mathbf{a}, \mathbf{i}$ та у збігаються з транскрипційними знаками, наприклад, у словах [ка́ва], [в ‘iкнó], [сухá]. Ці ж транскрипційні знаки автоматично виводяться також з йотованих алфавітних літер я, ї та ю: язи́к - [йази́к], їх - [йіх], юна́к - [йуна́к].

Літери е, и та о в транскрипції мають два відповідники (е та $\mathbf{e}^{\mathbf{u}} ; \mathbf{и}$ та и $\mathbf{u}^{\mathbf{e}}, \mathbf{0}$ та $\left.\mathbf{0}^{\mathbf{y}}\right)$ : перери́ти - [пе $\left.\mathbf{p e}^{u} \mathbf{p и ́ т и ] , ~ п о п у ́ х л и и ̆ ~ - ~ [ п о ~ п у ́ х л и е ̆ ~}\right]$. До першої пари транскрипційних варіантів (e та $\mathbf{e}^{\mathbf{u}}$ ) приєднуються ще два відповідники,

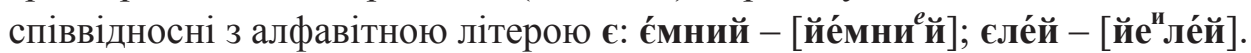

Літері й в орфоепічному словнику відповідає транскрипційний знак й: [йод]; [таки́й]. Ним у певних позиціях позначається також і початкова частина йотованих голосних: моя́ - [мойá], мої́ - [мойі́], моє́ - [мойé], мою́ - [мойý], 3'їхатися - [зйі́хати $е$ ся], м'я́со - [мйа́ссо].

Літера щ в орфоепічному словнику позначається сполученням двох транскрипційних знаків шч: щока́ - [шчока́], а м’який знак ь - за допомогою вертикальної рисочки: кінь - [к'ін'].

\subsection{3. Моделювання фонетики української мови}

Г ол ос н і. При позначенні на письмі голосних звуків береться до уваги їхня наголошеність. Наголошені звуки в українській літературній мові звучать чітко, тому в орфоепічному словнику вони позначаються транскрипційними знаками, тотожними за написанням з відповідними літерами українського алфавіту. Для 
ненаголошених голосних у разі, коли їхня вимова значно відрізняється від наголошених, використовуються прийняті в фонетиці транскрипційні знаки.

За результатами фізіолого-акустичних досліджень встановлено місця творення та ступень піднесення спинки язика при вимові голосних. На цих засадах було розроблено класифікаційну схему наголошування в сучасній українській літературній мові.

Літера та транскрипційний знак а в орфоепічному словнику позначають звук задній і неогублений. Літерами о та у транскрипційно позначено голосні заднього ряду, при вимові яких губи витягуються вперед. Літери е, и, і та їхні транскрипційні відповідники передають звуки середньо-переднього ряду, вимова яких потребує розтягування губ. Зву́кові, позначуваному транскрипційним знаком a, також приписується артикуляційна ознака «низьке піднесення»; транскрипційні i, у та и позначають звуки високого піднесення.

У ненаголошеній позиції найчастіше й найпомітніше змінюють своє звучання голосні, які на письмі передаються літерами е та и. Перший набуває наближеної вимови до и, тому в орфоепічному словнику він передається знаком $\mathbf{e}^{\mathbf{n}}$ (ме $\left.\mathbf{u}^{u} \mathbf{e}\right)$, а другий - до е; він у словнику транскрипційно подається знаком и (би́ти ${ }^{e}$. Якщо з обох боків літер е та и стоять м'які приголосні, їх вимова може набувати більш чи менш виразного передньо-високого піднесення. Такі випадки в орфоепічному словнику позначаються транскрипційним знаком с: аўстрі́йец'.

Вимова ненаголошеного о перед складом із наголошеним i та $\mathbf{y}$ (орфографічне написання i та ї; y та ю) наближається до у. Для такого ненаголошеного о в орфоепічному словнику вживається транскрипційний знак о $y$ : добірний - [доубі́рнией $]$, доїльний - [доуйі́і'ниӗ $],$ голу́бка - [го ${ }^{y}$

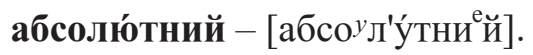

Приголосні. В українській фонетиці класифікаційними засадами приголосних $є$ орган вимови, спосіб творення та інтенсивність голосу. Розрізняються: губні приголосні (б, п, в, ф, м), передньоязикові (д, т, н, с, ц, 3, дे, л, p, ж, ш, дж, ч), середньоязиковий (й) та задньоязикові (г, к, г, х).

При транскрибуванні враховується, що губні і задньоязикові приголосні можуть бути твердими (ба́ба; газ; ма́ма; вал, ка́зка) та напівпом'якшеними (в ‘iл; г'iпc; к'iт; м'іст), середньоязиковий (й) завжди м’який, а передньоязикові (д, т, н, с, ц, 3, 8, л) бувають і м’якими, і твердими: [диск] і [д'ім], [табло́] i [т'і́сто], [сам] i [c'і́но]; звуки, позначувані в транскрипції літерами ж, ч, ш, вимовляються твердо i напівпом’якшено: [чан] і [ч'іп]; [шабло́н] i [ш'іст'], [жарки́й] i [ж`і́нка].

Дослідники звукового складу мови вважають, що літера і транскрипційний знак р використовується для позначення на письмі трьох його артикуляційних варіантів: твердого приголосного, як, наприклад, у словах [ра́ма], [рука́]; пом'якшеного - перед голосними звуками $\mathbf{a}, \mathbf{y}$ та о, що в орфографії позначаються йотованими я, ю та ьо: ряби́й - [р'аби́й $]$; варо - [вар'ý]; трьох - [тр'ох] i

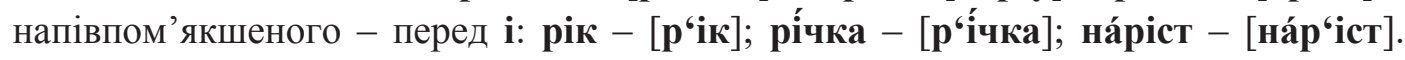


Артикуляційно і на слух між пом'якшеним та напівпом'якшеним р дуже мала різниця, тому вони в орфоепічному словнику транскрипційно відображені одним знаком. Для позначення обох варіантів вживається перевернута кома згори за літерою р: по́ряд - [по́р`ад]; трюмо́ - [тр`умо́]; рі́вно - [р‘'íвно; рі́́дний [р'їдни ${ }^{e}$ й].

Передньоязикові приголосні в певних умовах можуть бути подвоєними або подовженими. Орфографічно їхнє подвоєння та подовження передається написанням двох однакових літер поспіль. В орфоепічному словнику подвоєння і подовження позначено транскрипційним знаком, який складається з відповідної літери й двокрапкового розділового знака: підда́ти - [п'ід:а́ти]; щоде́нний [шчоде́н:и й $]$.

На стику префіксів і коренів та коренів і суфіксів найчастіше зустрічаються тверді подвоєні приголосні: обби́ти - [об:и́ти]; кі́нний - [к'íн:и й], а в кінці слів, переважно перед орфографічно вираженими флексіями за допомогою літер я, ю та i - подовжені м'які передньоязикові приголосні. У транскрипційному позначенні для них вживається відповідна літера, після якої йде знак пом'якшення чи напівпом'якшення і двокрапка: життя́- [жит':á]; зі́.лля -[3'і́л:a]; знання́ - [знан':á]; збі́жжя - [зб 'íiж':a].

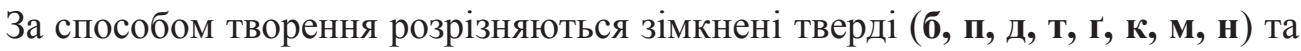

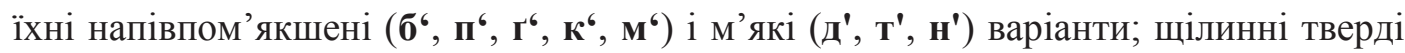

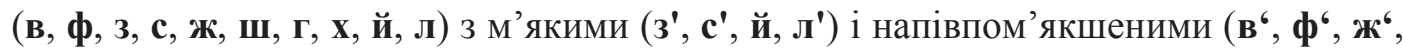
$\left.\mathbf{I I}^{6}, \mathbf{\Gamma}^{6}, \mathbf{x}^{6}\right)$ варіантами та дрижачий (p).

За інтенсивністю голосу у вимові приголосних виділяються дзвінкі (б, д, $\mathbf{3}$, ж, ఫ, жю, г, г), глухі (п, т, с, ц, ш, ч, к, х) і сонорні (м, н, л, р, й).

Автоматизоване переведення орфографічних форм в орфоепічні відбувається за такою схемою:
Алфавіт
A a
а в усіх позиціях;
Б 6
б - твердий; б
В $\mathbf{B} \quad \mathbf{B}-$ твердий; в ${ }^{6}-$ напівпом'якшений;
у - в кінці слова і складу та на початку слова після голосної;
Г $\quad$ г $\quad \boldsymbol{\Gamma}$ - твердий; $\boldsymbol{\Gamma}^{6}-$ напівпом'якшений;
I I $\mathbf{I}$ - твердий, $\mathbf{I}^{6}-$ напівпом'якшений;
Д д - твердий; д' - м'який або пом'якшений;
д: - твердий подвоєний, д': - пом'якшений і подовжений;
дж - дю - твердий, әє'- напівпом'якшений;
дз - дे - твердий, дे' - м'який або пом'якшений;
$\mathbf{E} \mathbf{e} \quad \mathbf{e}-$ під наголосом, $\mathbf{e}^{u}-$ ненаголошений,
$\mathbf{e}^{i}$ - ненаголошений після й перед м'яким або пом'якшеним приголосним;
E $\mathbf{\epsilon} \quad$ йe - ненаголошений на початку слова і після голосного;
'е - наголошений після передньоязикових;
'e - наголошений після губних, шиплячих, задньоязикових і p;
йe $^{u}, \mathrm{e}^{u}$ - ненаголошений перед твердими приголосними,
йе $^{i}-$ ненаголошений перед м'яким і пом'якшеним приголосним;
ж ж ж-твердий; ж6 - напівпом'якшений; ж: - твердий подвоєний; 
ж': - напівпом'якшений подовжений;

333 - твердий; з' - м'який або пом'якшений; з: - твердий подвоєний;

3': - м'який або пом'якшений подовжений;

И и $\mathbf{~ и ~ - ~ п і д ~ н а г о л о с о м , ~} \mathbf{u}^{\boldsymbol{e}}-$ ненаголошений;

I i $\quad$ i - на початку слова в ненаголошеній позиції та після приголосних;

$\mathbf{i}^{u}$ - на початку слова в наголошеній позиції;

Ï ї $\quad$ йi - на початку слова, після голосних та апострофа;

Й й й - середньоязиковий приголосний та початковий елемент йотованих;

К $\quad \mathbf{K} \quad \mathbf{\kappa}-$ твердий, $\mathbf{\kappa}^{\mathbf{6}}-$ напівпом'якшений;

Л $\quad$ л $\quad$ л - твердий; л' - м'який або пом'якшений;

л: - твердий здвоєний, л':- м'який подовжений;

М м $\mathbf{M}-$ твердий, $\mathbf{M}^{6}-$ напівпом'якшений;

H $\quad$ H $\quad \mathbf{H}-$ твердий; н' - м'який або пом'якшений; н: - твердий подвоєний;

н': - м'який подовжений;

O $\mathbf{0} \mathbf{0}$ - під наголосом та в інших позиціях, крім $\boldsymbol{0}^{y}-$ перед наголошеним складом $3 \mathbf{y}$

або i (орфографічними у, ю, i та ї);

П I $\quad$ I - твердий; $\boldsymbol{\Pi}^{\mathbf{6}}-$ напівпом'якшений;

P p $\quad \mathbf{p}$ - твердий; $\mathbf{p}^{6}-$ пом'якшений та напівпом'якшений;

C c c - твердий; c' - м'який або пом'якшений; c: - твердий подвоєний; c': - м'який

чи пом'якшений і подовжений;

T T T $\mathbf{T}$ - твердий; $\mathbf{T}^{\prime}-$ м'який, т: - твердий подвоєний, $\mathbf{T}^{\prime}:-$ м'який подовжений;

У $\mathbf{y} \quad \mathbf{y}-$ в усіх позиціях;

Ф $\quad \boldsymbol{\phi} \quad \boldsymbol{\phi}-$ твердий; $\boldsymbol{\phi}^{\mathbf{6}}-$ напівпом'якшений;

$\mathbf{X} \quad \mathbf{x} \quad \mathbf{x}-$ твердий; $\mathbf{x}^{6}-$ напівпом'якшений;

Ц ц ц - твердий, ц' - пом'якшений, ц': - пом'якшений подовжений;

Ч ч $\mathbf{ч}-$ твердий, $\mathbf{4}^{6}-$ напівпом'якшений;

ч': - напівпом'якшений подовжений;

III $\quad$ II $\quad$ II - твердий, $\mathbf{W}^{\mathbf{6}}$ - напівпом'якшений;

ш': - напівпом'якшений подовжений;

Щ ш шч - твердий; шч' $\mathbf{w}^{\mathbf{2}}$ напівпом'якшений;

b b ' (риска згори) - після передньоязикових приголосних;

Ю ю йу - на початку слова, після голосних та апострофа;

'у - після м'яких і пом'якшених приголосних;

'y - після напівпом'якшених приголосних;

я я йа - на початку слова, після голосних та апострофа;

'а - після м'яких і пом'якшених приголосних;

'a - після напівпом'якшених приголосних.

Фонетичні умови пом'якшення приголосних. Фонологія розрізняє три ступені пом'якшення приголосних. За цією ознакою усі приголосні розподіляються, відповідно, на три групи: м’які (д', т', н', л'), пом'якшені (с', з',

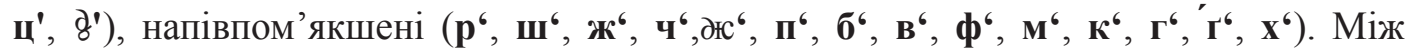
м'якими і пом'якшеними передньоязиковими приголосними на слух дуже мала різниця, тому в орфоепічному словнику для позначення м'яких і пом'якшених передньоязикових приголосних використовується один транскрипційний знак рисочка згори за літерою, якою позначено відповідний м'який або пом'якшений приголосний: чародійний - [чаро д''ійнией]; тільни́к - [т'іл'ни́к]; ліцензійний -

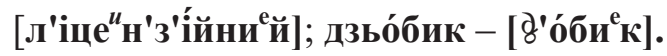

Пом'якшення та напівпом'якшення приголосних відбувається послідовно

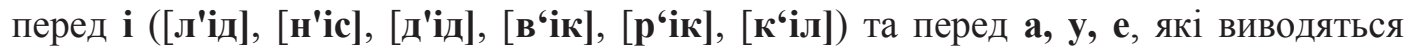


автоматизовано з алфавітних я, ю, с: тягти́ - [т'агти́], нюа́нс - [н'уáнс], си́нє [си́н'e' $\mathbf{e}^{\mathrm{i}}$.

Передньоязикові приголосні можуть бути м’якими в кінці слова і складу. Автоматизована система їх розпізнає та відображає в функції «Транскрипція» граматичного словника за наявністю після них в орфографічному варіанті м'якого знака: ба́тько - [ба́т'ко]; міць - [м'іц'], суспі́льство - [сусп'і́л'ство].

Фонетичні умови асиміляції приголосних. Вимова приголосних при збігу в мовленні має деякі особливості, що знаходять відображення в орфоепічному словнику. До них належить, зокрема, часткова та повна асиміляція попереднього приголосного з наступним приголосним.

Часткова асиміляція полягає в уподібненні попереднього звуку до наступного за деякою артикуляційною ознакою, наприклад, дзвінкістю. При цьому типі асиміляції наступна дзвінка приголосна в слові одзвінчує попередню глуху приголосну: боротьба́ - [бород'ба́]; вокза́л - [вогза́л]; о́тже - [о́дже ${ }^{u}$; кісьба́ - [к'iз'бá $]$ та ін.

Повною асиміляцією називається вподібнення звуків, при якому попередній приголосний цілком зливається у вимові з наступним приголосним: безжу́рний -

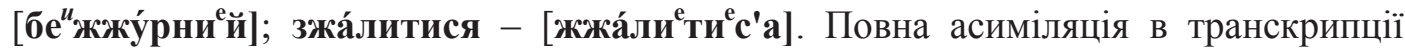
передається поєднанням відповідної асимілюючої приголосної 3 наступним

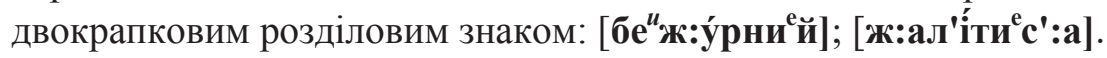

Повній асиміляції найчастіше піддаються свистячі $(3, \mathbf{c})$ перед шиплячими (ж, ш) і шиплячі перед свистячими: безжа́лісний - [бенж:а́л'існией]; б’є́шся [бйе́с':a]. Якщо приголосний т при словотворі або дієвідмінюванні опиняється перед с, ш, ц і ч, повна асиміляція призводить до їхнього артикуляційного злиття в один складний звук, що має назву «африкат»: коро́тший - [коро́ч:иӗ]; вітчи́зна - [в 'іч:и́зна].

Асиміляція приголосних за глухістю в сучасній українській літературній мові дуже обмежена. Експериментальною фонетикою цей тип асиміляції встановлений тільки для прийменника i префіксу «з» та на префіксальнокореневій межі, вираженій свистячим «з» та початковим глухим приголосним кореня: 3 по́ділом - [спо́д'ілом], зсі́кти - $\left[\mathbf{c}^{\prime}:\right.$ ікти $]$, безтурбо́тний -

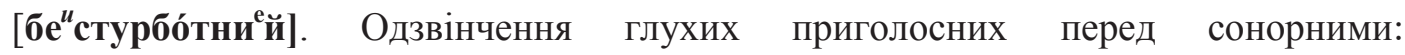
[см“ішли́ви ей], [три па́лиёи], [фре́ска] в українській мові не встановлено.

У разі збігу на морфемних швах свистячих із шиплячими чи навпаки, асиміляція, що вникає, може бути частковою і повною: пісча́ний - [п'ішча́ний]; зши́ток - [ш:и́ток]. Такі фонетичні перетворення кваліфікуються в фонетиці як асиміляція за місцем і способом творення.

Асиміляція за м'якістю стосується в основному передньоязикових приголосних (3, с, శ, ц, д, т, н, л), які будучи м'якими або пом'якшеними в певних фонетичних позиціях, уподібнюють собі (хоча й непослідовно) попередні

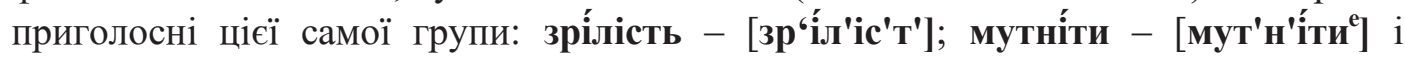


[мутн'і́ти ${ }^{\mathrm{e}}$ ]. У таких випадках знак пом'якшення береться в дужки: [мут ${ }^{(\bullet)} \mathbf{H}^{\prime}$ 'іти]. Всі напівпом'якшені $\left(\mathbf{p}^{6}, \mathbf{\kappa}^{6}, \mathbf{r}^{6}, \mathbf{r}^{6}, \mathbf{m}^{6}, \boldsymbol{\sigma}^{6}, \mathbf{B}^{6}, \boldsymbol{\phi}^{6}, \mathbf{w}^{6}, \mathbf{4}^{6}, \boldsymbol{ж}^{6}\right)$, зазвичай, не асимілюють за м’якістю попередніх приголосних. Виняток становлять с, 3, ц, дे, які можуть пом'якшуватися й перед губними напівпом'якшеними в словах типу

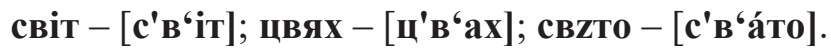

\subsection{4. Моделювання наголошування в системі транскрипції}

Граматика розрізняє основне та побічне наголошування - цей ефект знаходить відображення в граматичному словнику. Основне наголошування позначається нахиленою вправо рисочкою над буквою чи транскрипційним знаком наголошеного звука: [кв ‘iтко́вией]; [ви́рій]. Для позначення побічного наголошування вживається нахилена вліво рисочка: [мото̀робуд'іўни́к].

У сучасній українській літературній мові основний наголос падає на прості слова: [акти в'і́ст); [арши́н] і переважно на кінцеву частину складних слів: [вну̀трішн'огоспода́рс'кий]; [баво̀ўноочи́шчувач]. Складні слова в орфоепічному словнику представлені тими варіантами, які в сучасній українській літературній мові пишуться разом: [ме доно́с]; [бджо̀лозапи́лювач]. У складних словах основний наголос, що падає на другу частину, переважно збігається 3 наголошуванням співвідносного простого слова. Порівн.: [ву̀з'коспец'іа́л'ни'й] і [спец'іа́л'ни'й]; [во̀довим'íp'увал'ни'й] і [вим'і́р'увал'нией]. Побічний наголос ставиться у складних словах, частини яких мисляться як самостійні.

У складних словах основний наголос буває тільки один, тоді як побічних може бути декілька: великогабари́тний - [велѝкогабари́тнией], автомотоспорти́вний - [а̀втомо̀тоспорти́вни й]; водомастилозапра́вник [во̀домастѝлозапра́вни ке].

Побічний наголос у двокомпонентних складних словах припадає на першу частину: [ваго̀норемо́нтни й]; [далѐкогл'а́дни' й]. Місце побічного наголосу в ній збігається з місцем основного у вихідній формі простого слова, якщо перша частина складного слова утворена від простого зі сталим наголошуванням. Порівн.: [конкурѐнтоспромо́жни й] i [конкуре́нтни й]; [каўчу̀коно́с'н'ic'т'] i [каўчу́к].

Якщо відприкметникові прості прислівники можуть виступати 3 варіативним основним наголошуванням, то в складних словах ця варіативність відображається у вигляді двох побічних наголосів, які транскрипційно передаються в словнику подвійним написанням складного слова, де різне побічне наголошування супроводжується i певними фонетичними змінами:

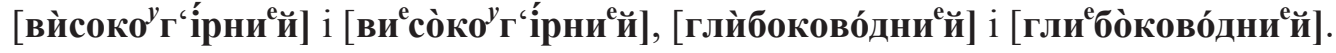

У непрямих відмінках складних займенників типу абихто, абищо, абичий, а також абиякий 3 побічним наголосом вимовляється кінцева частина: 
[аби́чийо̀го], [аби́йаку̀йу] та ін. Побічний наголос стоїть на кінцевих прислівниках типу [аби́кого̀], [аби́кудѝ] і под.

Побічний наголос у граматичному словнику проставляється на останньому складі частини складного слова, вираженої числівником, яка стоїть перед частиною з основним наголосом: [де “с'атѝпове

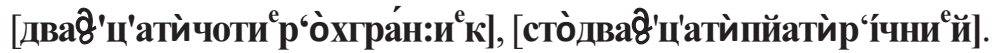

У порівнянні 3 орфоепічним Словником української мови реєстр Інтегрованої лексикографічної системи «Словники України» значно розширено, зокрема, включено слова, що пишуться через дефіс, та словосполучення.

Слова, що пишуться через дефіс, зазвичай, мають один основний наголос, інші частини можуть мати побічний наголос: артилерійсько-стрілецький [арти 'ле"р ‘ійс'костр“іле́ц'кией]; ясла-садок - [йа̀сласадо́к]; генерал-майорінженер - [ге"не зазвичай, свій окремий наголос: Андріївська церква - [андр ‘ійіўс’ка це́рква].

Прийменники, що не мають самостійного наголосу, утворюють фонетичне ціле з наступним іменником: до невпізнанності - [доне уйп'ізна́н:ос'т’i]; на око [нао́ко] тощо.

\section{6. Система маркування УНЛК}

\subsection{1. Бібліографічний та структурний опис документів в УНЛК}

В УНЛК витримується тенденція до стандартного способу представлення структур даних з урахуванням вимог TEI та CES, а також з використанням інструментів розмітки (markup), про які йшлося у попередніх підрозділах.

Оскільки до складу УНЛК входять синхронічні та діахронічні масиви (створені, відповідно, на сучасних текстах та на текстах минулих мовних епох), які охоплюють як тексти нормованої літературної мови, так і спеціалізовані (термінологічні, діалектні, фольклорні тощо), особливого значення набуває набір бібліографічних параметрів, кожен з яких є точкою входу до корпусу.

Визначення типу документів в УНЛК здійснюється за допомогою мов маркування з базовою мовою SGML, принципи якої, нагадаємо, використано у багатьох інших мовах маркування (XML, XHTML, XQL, VML тощо). Загальноприйнятим стандартом маркування УНЛК, як зазначалося, слугує CES (Corpus Encoding Standard), який вимагає опису текстів корпусу в форматі DTD (Document Type Definition).

Теги DTD розподіляються на три рівні: 1) теги ядра (core tags); 2) базові теги (base tags); 3) додаткові теги (additional tags). Теги кожного рівня забезпечують бібліографічне, структурне та лінгвістичне маркування ЛК: 
Наприклад, бібліографічне маркування окремого документа ЛК в форматі DTD має вигляд:

$<!$ ELEMENT library (volume*)>

$<$ !ELEMENT volume (bibliography, toc?, preface*, postface*, comment*, text, references)>

$<$ !ELEMENT bibliography (lang, udk, author+, bookname, edition, size, series,

isbn, subject_group, vol_name, keyword*, overhead, path, responsibility)>

$<$ !ELEMENT lang EMPTY>

$<$ EELEMENT author (surname, initials)>

$<$ IELEMENT bookname (\#PCDATA)>

$<$ !ELEMENT edition EMPTY>

$<$ !ELEMENT vol_name EMPTY>

Кореневий тег ('library’) відповідає загальному масиву БД корпусу i включає будь-яку кількість елементів ('volume'). У складі ЛК кожен повнотекстовий документ має обов'язкові елементи: безпосередньо текст ('text'), бібліографічний опис ('bibliography'), зміст ('toc'), коментар ('comment'), посилання ('reference's) та факультативні: передмова ('preface'), післямова ('postface'). Ці елементи можуть мати уточнення у вигляді атрибутів. Наприклад, тег кореневий тег 'body' серед інших має атрибут 'lang', що зазначає локально мову тієї чи іншої структурної частини документа (наприклад, цитати мовою оригіналу).

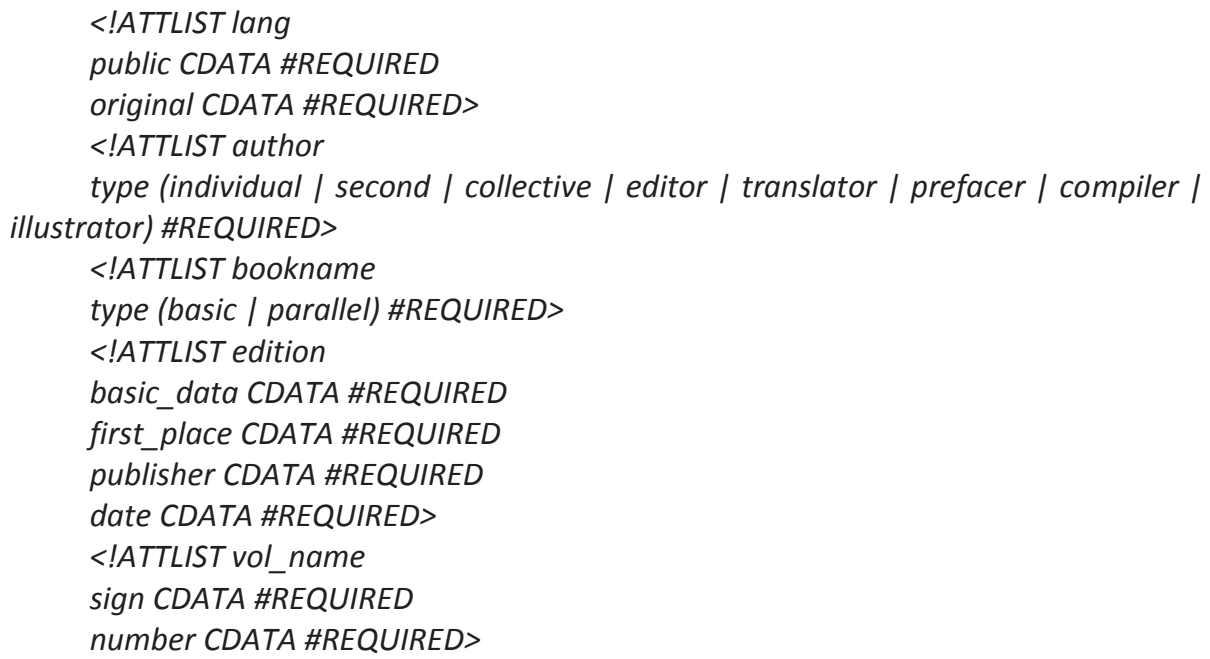

Реалізація цих структур за допомогою програми Altova XMLSpy уможливлює їхне табличне представлення. У табл. 19.1 наведено структуру бібліографічного опису авторів. 
Таблиця 19.1. Бібліографічний опис авторів

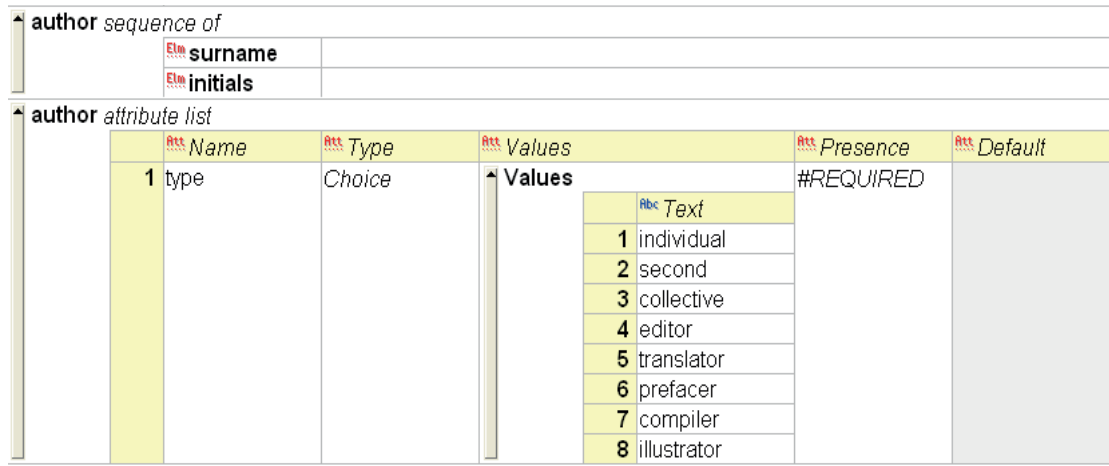

Наведена структура бібліографічного опису відповідає стандарту UNIMARC, обраного вихідним при створенні електронної бібліотеки УНЛК. Відповідність полів подано у табл. 19.2:

Таблиця 19.2. Відповідність бібліографічного опису стандарту UNIMARC

\begin{tabular}{|c|c|c|}
\hline Опис поля & Library_db & UNIMARC \\
\hline Мова видання & $\begin{array}{l}\text { lang.full_lang; } \\
\text { lang.short_lang; } \\
\text { type_lang.id_type_lang=1 }\end{array}$ & $101-\mathrm{A}$ \\
\hline Мова оригіналу & $\begin{array}{l}\text { lang.full_lang; } \\
\text { lang.short_lang; } \\
\text { type_lang.id_type_lang=2 }\end{array}$ & $101-\mathrm{C}$ \\
\hline УДК & main_record.udc & 675-A \\
\hline Індивідуальний автор (прізвище) & $\begin{array}{l}\text { avtor.surname } \\
\text { type_avtor.id_type_avtor=1 }\end{array}$ & $700-\mathrm{A}$ \\
\hline $\begin{array}{l}\text { Індивідуальний автор (ім’я та по } \\
\text { батькові) }\end{array}$ & $\begin{array}{l}\text { avtor.initials } \\
\text { type_avtor.id_type_avtor=1 }\end{array}$ & $700-\mathrm{B}$ \\
\hline Другий автор (прізвище) & $\begin{array}{l}\text { avtor.surname } \\
\text { type_avtor.id_type_avtor=2 }\end{array}$ & $702-\mathrm{A}$ \\
\hline Другий автор (ім’я та по батькові) & $\begin{array}{l}\text { avtor.initials } \\
\text { type_avtor.id_type_avtor=2 }\end{array}$ & 702-B \\
\hline $\begin{array}{l}\text { Колективний автор (установа, } \\
\text { підприємство) }\end{array}$ & $\begin{array}{l}\text { avtor.surname } \\
\text { type_avtor.id_type_avtor=3 }\end{array}$ & $702-\mathrm{A}$ \\
\hline Назва книги (основна назва) & $\begin{array}{l}\text { record_title.full_title; } \\
\text { type_title.id_type_title=1 }\end{array}$ & $200-\mathrm{A}$ \\
\hline Назва книги (паралельна назва) & $\begin{array}{l}\text { record_title.full_title; } \\
\text { type_title.id_type_title=2 }\end{array}$ & $200-\mathrm{D}$ \\
\hline Відомості про видання і вихідні дані & main_record.vidom_isdatel & 205-A \\
\hline Перше місце видання & place_isdatel.city; & $205-\mathrm{B}$ \\
\hline Видавництво або видавнича організація & isdatel.name_isdatel & $205-\mathrm{B}$ \\
\hline Дата видання & $\begin{array}{l}\text { main_record.data_isdatel_first; } \\
\text { main_record. data_isdatel_second; } \\
\text { main_record. data_isdatel } \\
\text { _comment }\end{array}$ & $205-\mathrm{B}$ \\
\hline $\begin{array}{l}\text { Кількісна характеристика (розмір в } \\
\text { кілобайтах) }\end{array}$ & file.file_size & 215-D \\
\hline
\end{tabular}




\begin{tabular}{|c|c|c|}
\hline Область серії (основна назва серії) & seriya.seriya_des & $225-\mathrm{A}$ \\
\hline ISBN & main_record.isbnw & $010-\mathrm{A}$ \\
\hline $\begin{array}{l}\text { Тематична група томів (назва тематичної } \\
\text { групи томів) }\end{array}$ & garn.gern_des & $610-\mathrm{A}$ \\
\hline $\begin{array}{l}\text { Назва тому(позначка і порядковий номер } \\
\text { тому) }\end{array}$ & $\begin{array}{l}\text { main_record.volume_first; } \\
\text { main_record.volume_second; } \\
\text { main_record.volume_comment }\end{array}$ & $207-A$ \\
\hline Редактор(и) (прізвище) & $\begin{array}{l}\text { avtor.surname } \\
\text { type_avtor.id_type_avtor=5 }\end{array}$ & $702-\mathrm{A}$ \\
\hline Редактор(и) (ім’я та по батькові) & $\begin{array}{l}\text { avtor.initials } \\
\text { type_avtor.id_type_avtor=5 }\end{array}$ & $702-B$ \\
\hline Перекладач(i) (прізвище) & $\begin{array}{l}\text { avtor.surname } \\
\text { type_avtor.id_type_avtor=8 }\end{array}$ & $702-\mathrm{A}$ \\
\hline Перекладач(i) (ім’я та по батькові) & $\begin{array}{l}\text { avtor.initials } \\
\text { type_avtor.id_type_avtor }=8\end{array}$ & $702-\mathrm{B}$ \\
\hline $\begin{array}{l}\text { Автор(и) передмови вступних статей } \\
\text { (прізвище) }\end{array}$ & $\begin{array}{l}\text { avtor.surname } \\
\text { type_avtor.id_type_avtor=9 }\end{array}$ & $702-\mathrm{A}$ \\
\hline $\begin{array}{l}\text { Автор(и) передмови вступних статей } \\
\text { (iм’я та по батькові) }\end{array}$ & $\begin{array}{l}\text { avtor.initials } \\
\text { type_avtor.id_type_avtor=9 }\end{array}$ & $702-B$ \\
\hline Складач(i) (прізвище) & $\begin{array}{l}\text { avtor.surname } \\
\text { type_avtor.id_type_avtor=4 }\end{array}$ & $702-\mathrm{A}$ \\
\hline Складач(i) (ім’я та по батькові) & $\begin{array}{l}\text { avtor.initials } \\
\text { type_avtor.id_type_avtor=4 }\end{array}$ & $702-B$ \\
\hline Ілюстратор(и) (прізвище) & $\begin{array}{l}\text { avtor.surname } \\
\text { type_avtor.id_type_avtor=11 }\end{array}$ & $702-\mathrm{A}$ \\
\hline Ілюстратор(и) (ім’я та по батькові) & $\begin{array}{l}\text { avtor.initials } \\
\text { type_avtor.id_type_avtor=11 }\end{array}$ & $702-B$ \\
\hline Ключові слова & Key_words.key_words & $615-\mathrm{A}$ \\
\hline Службова інформація (агентство) & main_record.agenstvo & $801-\mathrm{A}$ \\
\hline Шлях до файлу & File.path_to_file & $951-\mathrm{A}$ \\
\hline Відомості про відповідальність & main_record.vidpovid & $700-\mathrm{A}$ \\
\hline
\end{tabular}

На рис. 19.1 наведено XML-схему (XSD) бібліографічного опису документа.

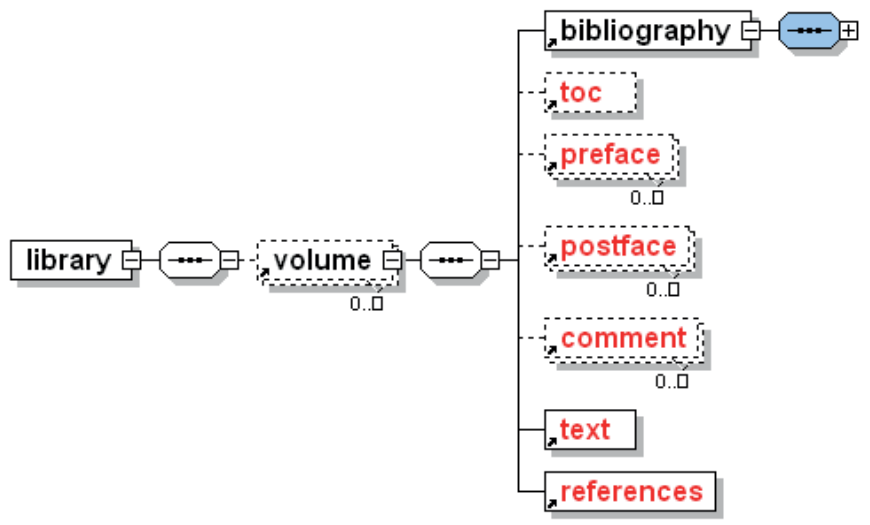

Рис. 19.1. XML-схема (XSD) бібліографічного опису документа 


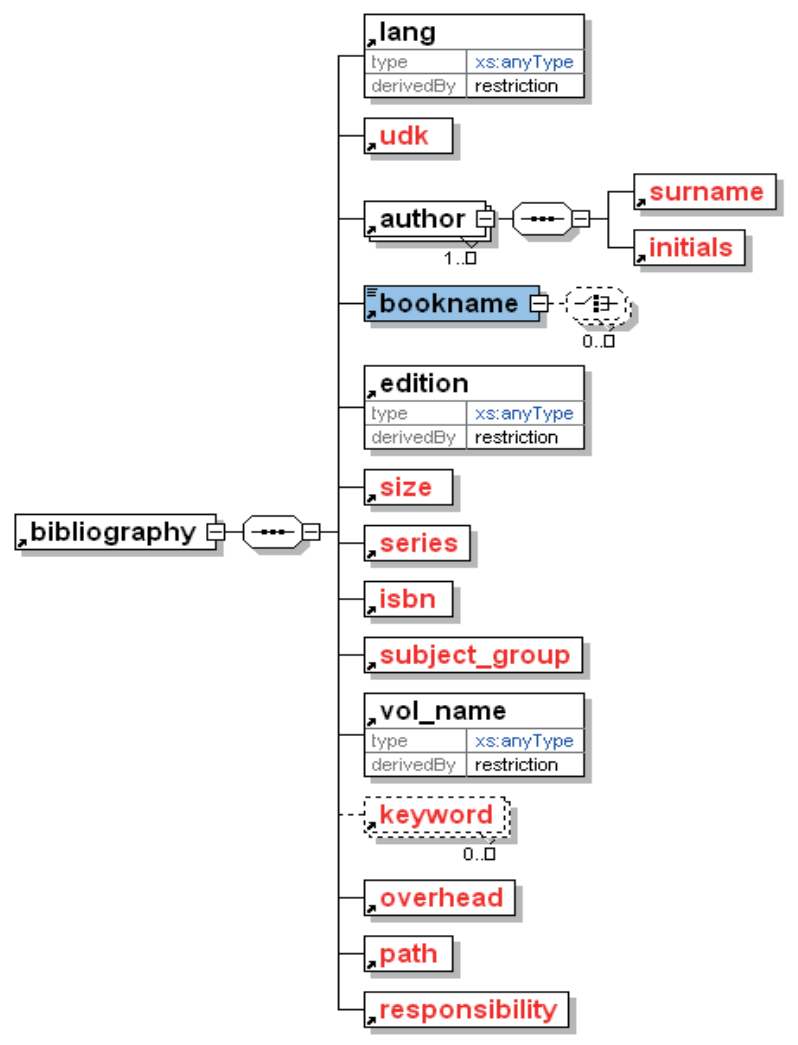

Рис. 19.2. XML-схема (XSD)

Теги базового рівня описують форму представлення тексту документа, якому відповідає кореневий тег 'text', уведений на попередньому рівні. Схема тегів структурного опису документа має вигляд (рис. 19.3): 


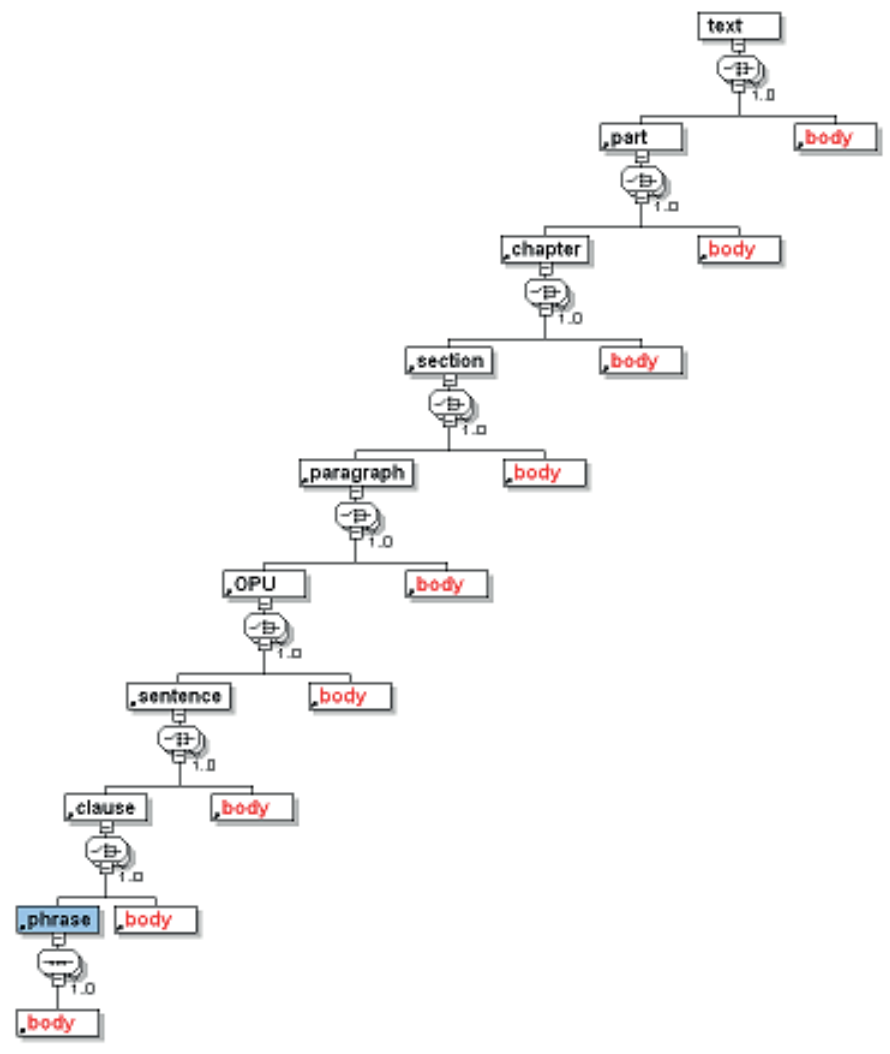

Рис. 19.3. XML-схема базових тегів структурного опису документа

DTD-опис базових тегів структурного опису документа:

$<$ !ELEMENT text (part | body)+>

$<$ !ELEMENT part (chapter | body)+>

$<$ !ELEMENT chapter (section | body)+>

$<$ !ELEMENT section (paragraph | body)+>

$<$ !ELEMENT paragraph (OPU | body)+>

$<$ !ELEMENT OPU (sentence / body)+>

$<$ !ELEMENT sentence (clause / body)+>

$<$ !ELEMENT clause (phrase | body)+>

$<$ !ELEMENT phrase (body)+>

$<! A T T L I S T$ part

name (PCDATA) \#IMPLIED

$>$

$<$ !ATTLIST chapter

name (PCDATA) \#IMPLIED

$>$

$<$ !ATTLIST section

name (PCDATA) \#IMPLIED

$>$ 
$<!$ ATTLIST paragraph

name (PCDATA) \#IMPLIED

$>$

$<$ !ATTLIST sentence

structure (simple / asyndetic / coordinate / subordinate / incentive) \#REQUIRED

type (interrogative / affirmative / exclamatory) \#REQUIRED

$>$

$<$ !ATTLIST phrase

type (phraseologism / idiom / word_equ) \#REQUIRED

$>$

$<!$ ATTLIST body

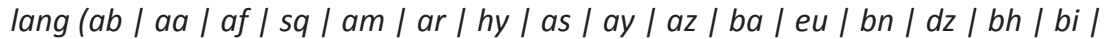
$\mathrm{br} / \mathrm{bg} / \mathrm{my} / \mathrm{be} / \mathrm{km}$ / ca / zh / co / hr / cs / da / nl / en / eo / et / fo / fa / fj / fi / fr | fy / gl / gd / gv / ka / de / el / kl / gn / gu / ha / he / hi / hu / is / id / ia / ie / iu | ik

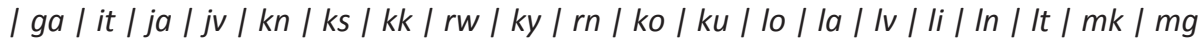

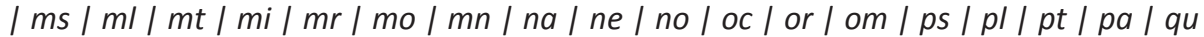
| rm | ro | ru | sm | sg | sa | sr | sh | st | tn | sn | sd | si | ss | sk | sl | so | es | su |

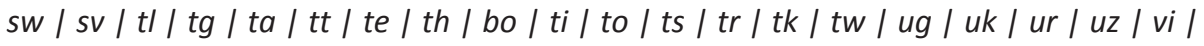
vo / cy / wo / xh / yi / yo / zu) "uk"

$>$

Кодування мов відбувається у стандарті ISO 639:1988; відповідну таблицю наведено у Додатку Б.

У табл. 19.3 представлено структуру тега 'sentence' для опису речень.

Таблиця 19.3. Структура тега 'sentence'

\begin{tabular}{|c|c|c|c|c|c|c|c|c|}
\hline \multicolumn{9}{|c|}{ - sentence attribute list } \\
\hline & & Att Name & Att Type & \multicolumn{3}{|l|}{ Att Values } & Att Presence & Att Default \\
\hline & \multirow[t]{7}{*}{1} & \multirow[t]{7}{*}{ structure } & \multirow[t]{7}{*}{ Choice } & \multicolumn{3}{|l|}{ - Values } & \multirow[t]{7}{*}{ \#REQUIRED } & \multirow[t]{7}{*}{ simple } \\
\hline & & & & & & Abc Text & & \\
\hline & & & & & & simple & & \\
\hline & & & & & 2 & asyndetic & & \\
\hline & & & & & 3 & coordinate & & \\
\hline & & & & & 4 & subordinate & & \\
\hline & & & & & 5 & incentive & & \\
\hline & \multirow[t]{5}{*}{2} & \multirow[t]{5}{*}{ type } & \multirow[t]{5}{*}{ Choice } & \multirow[t]{5}{*}{4 Values } & & & \multirow[t]{5}{*}{ \#REQUIRED } & \multirow[t]{5}{*}{ affirmative } \\
\hline & & & & & & Abc Text & & \\
\hline & & & & & 1 & interrogative & & \\
\hline & & & & & 2 & affirmative & & \\
\hline - & & & & & 3 & exclamatory & & \\
\hline
\end{tabular}

Нагадаємо, що лінгвістичне маркування ЛК має декілька основних рівнів, а саме: морфологічний, лексичний, синтаксичний, семантичний. На рис. 19.4 наведено структуру тегів морфологічного рівня маркування речення. 


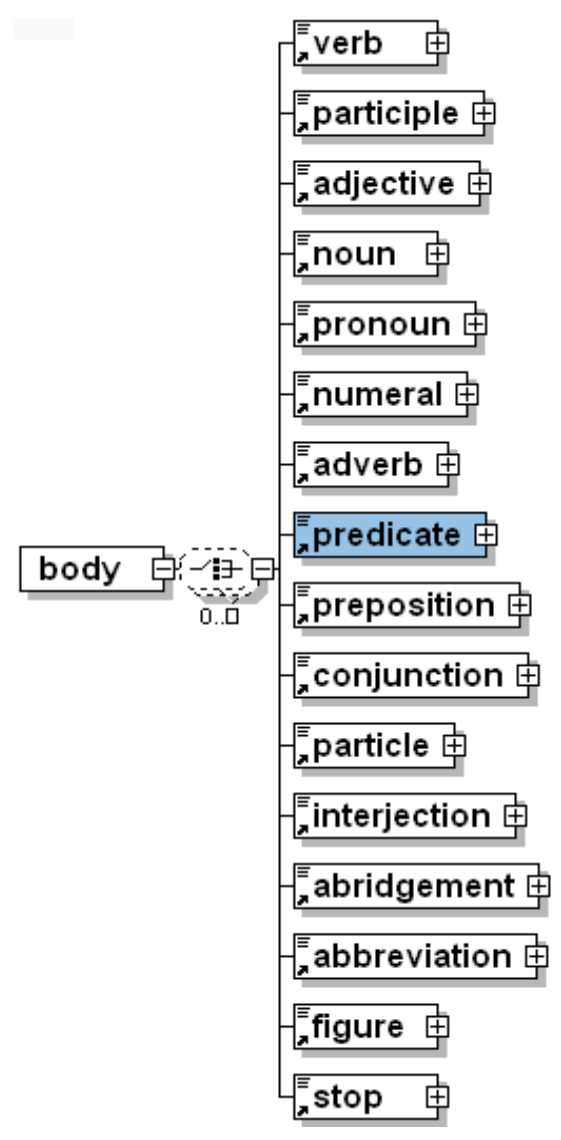

Рис. 19.4. Структура тега 'sentence'

Кореневий тег 'body' містить теги, які ідентифікують частини мови ('verb', 'participle', 'adjective', 'noun', 'pronoun', 'numeral', 'adverb', 'predicate', 'preposition', 'conjunction', 'particle', 'interjection', 'abridgement', 'abbreviation', 'figure'), а також пунктуаційні знаки ('stop'). Кожний 3 цих тегів (окрім пунктуаційного), має відповідні до кожної частини мови атрибути, що визначають iї граматичні ознаки. Наприклад, опис дієслова у DTD-форматі має вигляд:

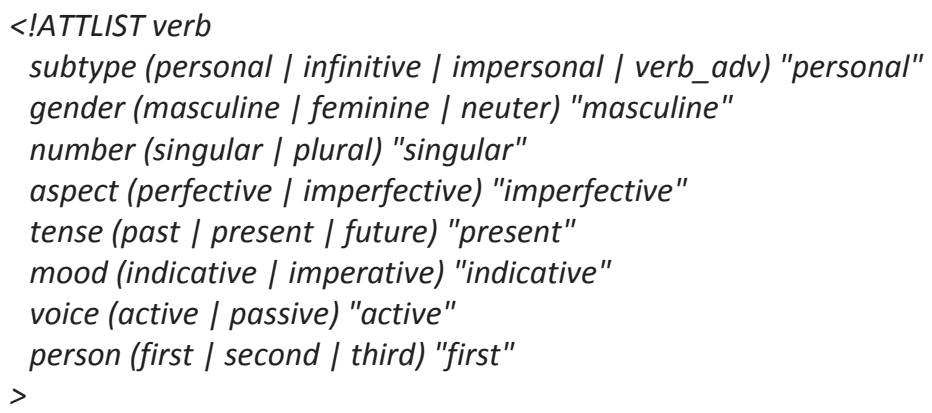


Опис дієслова в табличному представленні (табл. 19.4).

Таблиця 19.4

\begin{tabular}{|c|c|c|c|c|c|c|c|}
\hline \multicolumn{8}{|c|}{ - verb attribute list } \\
\hline \multirow{7}{*}{1} & \multirow{7}{*}{$\begin{array}{l}\text { Att Name } \\
\text { subtype }\end{array}$} & \multirow{7}{*}{$\begin{array}{l}\text { Ate Type } \\
\text { Choice }\end{array}$} & \multicolumn{3}{|l|}{ Att Values } & \multirow[t]{7}{*}{ Att Presence } & \multirow{7}{*}{$\begin{array}{l}\text { Att Defauit } \\
\text { personal }\end{array}$} \\
\hline & & & - Values & & & & \\
\hline & & & & & Abc Text & & \\
\hline & & & & 1 & personal & & \\
\hline & & & & 2 & infinitive & & \\
\hline & & & & 3 & impersonal & & \\
\hline & & & \rfloor & 4 & verb_adv & & \\
\hline \multirow[t]{5}{*}{2} & \multirow[t]{5}{*}{ gender } & \multirow[t]{5}{*}{ Choice } & \multirow[t]{5}{*}{ - Values } & & & & \multirow[t]{5}{*}{ masculine } \\
\hline & & & & & abc Text & & \\
\hline & & & & 1 & masculine & & \\
\hline & & & & 2 & feminine & & \\
\hline & & & & 3 & neuter & & \\
\hline 3 & \multirow[t]{4}{*}{ number } & \multirow[t]{4}{*}{ Choice } & \multirow[t]{4}{*}{ Values } & & & & \multirow[t]{4}{*}{ singular } \\
\hline & & & & & Abc Text & & \\
\hline & & & & 1 & singular & & \\
\hline & & & & 2 & plural & & \\
\hline 4 & \multirow[t]{4}{*}{ aspect } & \multirow[t]{4}{*}{ Choice } & \multirow[t]{4}{*}{ - Values } & & & & \multirow[t]{4}{*}{ imperfective } \\
\hline & & & & & Abc Text & & \\
\hline & & & & 1 & perfective & & \\
\hline & & & & 2 & imperfective & & \\
\hline 5 & \multirow[t]{5}{*}{ tense } & \multirow[t]{5}{*}{ Choice } & \multirow[t]{5}{*}{ - Values } & & & & present \\
\hline & & & & & Abc Text & & \\
\hline & & & & 1 & past & & \\
\hline & & & & 2 & present & & \\
\hline & & & & 3 & future & & \\
\hline 6 & mood & Choice & - Values & & & & indicative \\
\hline & & & & & Abc Text & & \\
\hline & & & & 1 & indicative & & \\
\hline & & & & 2 & imperative & & \\
\hline 7 & voice & Choice & - Values & & & & active \\
\hline & & & & & Abc Text & & \\
\hline & & & & 1 & active & & \\
\hline & & & & 2 & passive & & \\
\hline 8 & person & Choice & - Values & & & & first \\
\hline & & & & & Abc Text & & \\
\hline & & & & 1 & first & & \\
\hline & & & & 2 & second & & \\
\hline$\perp$ & & & \rfloor & 3 & third & & \\
\hline
\end{tabular}

Марковані документи використовуються різноманітним ПЗ, і тому в деяких випадках доцільно застосовувати альтернативну форму морфологічного маркування, за якої сукупність атрибутів, що визначають конкретну форму певної частини мови, замінюється одним (code). Множина його можливих значень відповідає усім можливим осмисленим комбінаціям значень атрибутів слова. DTD таких тегів має вигляд:

<!ENTITY \% verbcode "code (VA | VB | VC | VD | VE | VF | VG | VH | VI | VJ | VR | VS | VT | VU | VV | VW | WA | WB | WC | WD | WE | WF | WG | WH | WI | WJ | WR | WS | WT | WU | WW | UA | UB | UC | UD | UE | UF | UG | UH | UI | UJ | UK | UL | UM | UN | UO | UP | UQ | UR | US | UT | UU | UV | UW | YA | YB | YC | YD | YE | YF | YG | YH | YI | YJ | YK | YL | YM | YN | YO | YP | YQ | YR | YS | YT | YU | YW)">

$<$ !ATTLIST verb

\%verbcode; \#IMPLIED

$>$ 
Йому відповідає таблична форма представлення (табл. 19.5).

Таблиця 19.5 (фрагмент)

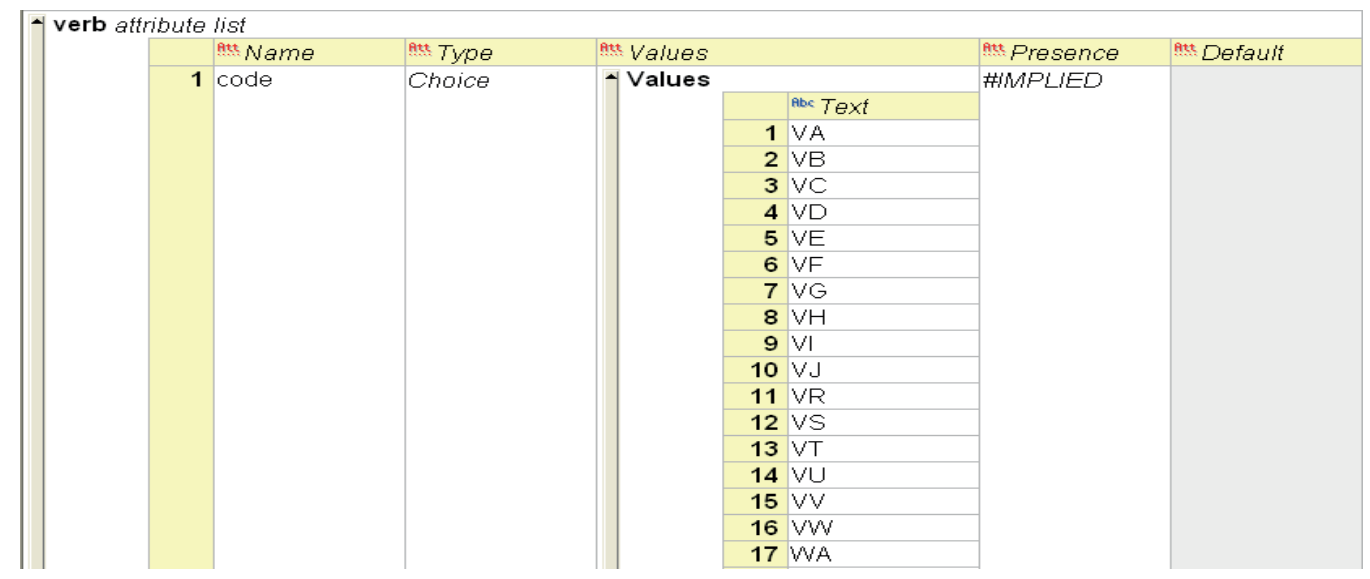

Морфологічні характеристики словоформ представляються у вигляді двосимвольних кодів (табл. 19.6).

Таблиця 19.6. Двосимвольні морфологічні коди в УНЛК (фрагмент)

\begin{tabular}{|c|c|c|}
\hline Граматичне значення & $\begin{array}{l}\text { Морф. } \\
\text { код }\end{array}$ & Приклад \\
\hline Дієслово, інфінітив, доконаний вид, активний стан & VA & прочитати \\
\hline Дієслово, безособова форма, доконаний вид & VV & прочитано \\
\hline $\begin{array}{l}\text { Дієслово, дієприслівник, доконаний вид, минулий час, } \\
\text { активний стан }\end{array}$ & VW & прочитавши \\
\hline Дієслово, інфінітив, недоконаний вид, активний стан & UA & читати \\
\hline $\begin{array}{l}\text { Дієслово, особова форма, недоконаний вид, теперішній час, } \\
\text { дійсний спосіб, активний стан, } 1 \text { особа, однина }\end{array}$ & UK & читаю \\
\hline \multicolumn{3}{|l|}{$\ldots$} \\
\hline $\begin{array}{l}\text { Дієприкметник, чоловічий рід, однина, називний відмінок, } \\
\text { доконаний вид, минулий час, пасивний }\end{array}$ & $\mathrm{CA}$ & зроблений \\
\hline $\begin{array}{l}\text { Дієприкметник, чоловічий рід, однина, родовий відмінок, } \\
\text { доконаний вид, минулий час, пасивний }\end{array}$ & $\mathrm{CB}$ & зробленого \\
\hline \multicolumn{3}{|l|}{$\ldots$} \\
\hline Прикметник, чоловічий рід, однина, називний відмінок & AA & червоний \\
\hline Прикметник, чоловічий рід, однина, родовий відмінок & $\mathrm{AB}$ & червоного \\
\hline \multicolumn{3}{|l|}{$\ldots$} \\
\hline Іменник загальний, чоловічий рід, однина, називний відмінок & MA & човен \\
\hline Іменник загальний, чоловічий рід, однина, родовий відмінок, & MB & човна \\
\hline Іменник загальний, жіночий рід, однина, називний відмінок & FA & квітка \\
\hline Іменник загальний, середній рід, однина, називний відмінок & NA & сериче \\
\hline Іменник власний, чоловічий рід, однина, називний відмінок & JA & Володимир \\
\hline \multicolumn{3}{|l|}{$\ldots$} \\
\hline Займенник-іменник, чоловічий рід, однина, називний відмінок & $\mathrm{OA}$ & він \\
\hline Займенник-іменник, чоловічий рід, однина, родовий відмінок & $\mathrm{OB}$ & його \\
\hline Невідмінюваний займенник & $\mathrm{OZ}$ & uัozo, $\ddot{\imath} \ddot{i}, \ddot{x}$ \\
\hline
\end{tabular}




\begin{tabular}{|l|c|l|}
\hline $\begin{array}{l}\text { Займенник-прикметник, чоловічий рід, однина, називний } \\
\text { відмінок }\end{array}$ & $\mathrm{RA}$ & кожний \\
\hline $\begin{array}{l}\text { Займенник-прикметник, чоловічий рід, однина, родовий } \\
\text { відмінок }\end{array}$ & $\mathrm{RB}$ & кожного \\
\hline$\ldots$ & $\mathrm{HS}$ & mpи \\
\hline Кількісний числівник, множина, називний відмінок & $\mathrm{HT}$ & трьох \\
\hline Кількісний числівник, множина, родовий відмінок & & \\
\hline$\ldots$ & $\mathrm{PB}$ & від \\
\hline Прийменник, який керує родовим відмінком & $\mathrm{PC}$ & наперекір \\
\hline Прийменник, який керує давальним відмінком & $\mathrm{T} 0$ & сьогоднi \\
\hline Прислівник & $\mathrm{X} 0$ & слід \\
\hline Предикатив (присудкове слово) & $\mathrm{SC}$ & та \\
\hline Сполучник сурядний & $\mathrm{SS}$ & бо \\
\hline Сполучник підрядний & $\mathrm{Z0}$ & жс \\
\hline Частка & $\mathrm{Q} 0$ & ой \\
\hline Вигук & $3 \mathrm{~A}$ & стор. \\
\hline Скорочення-слово & $3 \mathrm{~B}$ & m.д. \\
\hline Скорочення-словосполучення & $2 \mathrm{~A}$ & HATO \\
\hline Абревіатура & $1 \mathrm{~A}$ & 237 \\
\hline Число & & \\
\hline
\end{tabular}

Загальна кількість рядків таблиці дорівнює 384, що відповідає кількості можливих форм для слововживань в українській мові. Розмічений у такий спосіб XML-документ має більш компактне представлення. Так, для першого варіанта маркування вихідного тексту:

«Конституція Украӥни має найвищу юридичну силу. Закони та інші нормативно-правові акти приймаються на основі Конституції України і повинні відповідати їй.

Норми Конституичї України є нормами прямої дії. Звернення до суду для захисту конституційних прав і свобод людини і громадянина безпосередньо на підставі Конституиії Украӥни гарантується.»

маємо такий документ:

$<b o d y>$

$<$ noun subtype="common" gender="feminine" number="singular"

case="nominative" $>$ Конституція</noun $>$

$<$ noun subtype="proper" gender="feminine" number="singular"

case $=$ "genitive" $>$ Країни $</$ noun $>$

$<$ verb subtype="personal" aspect="imperfective" tense="present"

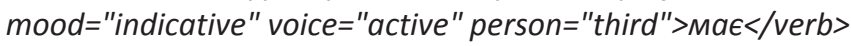

$<$ adjective subtype="variable" gender="feminine" number="singular"

case $=$ "accusative" $>$ найвищу $</$ adjective $>$

$<$ adjective subtype="variable" gender="feminine" number="singular"

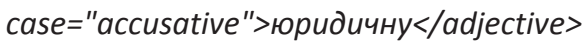

$<$ noun subtype="common" gender="feminine" number="singular"

case $=$ "accusative" $>$ cuлy $</$ noun $>$

$<$ stop $>$. $</$ stop $>$ 
$<$ noun subtype="common" gender="masculine" number="plural"

case="nominative" $>$ Закони $</$ noun $>$

$<$ conjunction subtype $=$ "coordinating" $>$ ma</conjunction $>$

$<$ pronoun subtype="adjective" number="plural" case="nominative">iнmi

$</$ pronoun $>$

$<$ adjective subtype="variable" number="plural"

case="nominative">нормативно-правові </adjective>

$<$ noun subtype="common" gender="masculine" number="plural"

case $=$ "nominative" $>$ akmu $</$ noun $>$

$<$ verb subtype="personal" aspect="imperfective" tense="present"

mood="indicative" voice="passive" person="third" >приймаються</verb>

$<$ preposition case $=$ "locative" $>$ Ha $</$ preposition $>$

$<$ noun subtype="common" gender="feminine" number="singular"

case="locative" >основi</noun>

$<$ noun subtype="common" gender="feminine" number="singular"

case $=$ "genitive" $>$ Конституuіï</noun $>$

$<$ noun subtype="proper" gender="feminine" number="singular"

case $=$ "genitive" $>$ України $</$ noun $>$

$<$ conjunction subtype $=$ "coordinating" $>i</$ conjunction $>$

$<$ adjective subtype="variable" number="plural" case="nominative" $>$ повинні

$<$ /adjective >

$<$ verb subtype="infinitive" aspect="imperfective"

voice ="active" >відповідаmu</verb $>$

$<$ pronoun subtype="noun" gender="feminine" number="singular"

case $=$ "dative" $>$ iü $</$ pronoun $>$

$<$ stop $>$. $<$ stop $>$

$<$ noun subtype="common" gender="feminine" number="plural"

case="nominative" $>$ Hормu $</$ noun $>$

$<$ noun subtype="common" gender="feminine" number="singular"

case="genitive" $>$ Конституції</noun>

$<$ noun subtype="proper" gender="feminine" number="singular"

case $=$ "genitive" $>$ України $</$ noun $>$

$<$ verb subtype="personal" aspect="imperfective" tense="present"

mood="indicative" voice="active" person="third" $>\epsilon</$ verb $>$

$<$ noun subtype="common" gender="feminine" number="plural"

case="ablative" > нормами $</$ noun $>$

$<$ adjective subtype="variable" gender="feminine" number="singular"

case $=$ "genitive">прямої </adjective>

$<$ noun subtype="common" gender="feminine" number="singular"

case $="$ genitive" $>$ diï $</$ noun $>$

$<$ stop $>$. $<$ stop $>$

$<$ noun subtype="common" gender="neuter" number="singular"

case $=$ "nominative" $>$ зернення $</$ noun $>$

$<$ preposition case $=$ "genitive" $>\partial o</$ preposition $>$

$<$ noun subtype="common" gender="masculine" number="singular"

case $="$ genitive" $>$ cydy $</$ noun $>$

$<$ preposition case $="$ genitive" $>\partial л я</$ preposition $>$

$<$ noun subtype="common" gender="masculine" number="singular"

case $=$ "genitive" $>3$ axucmy $</$ noun $>$ 
$<$ adjective subtype="variable" number="plural" case="genitive"> конституційних</adjective>

$<$ noun subtype="common" gender="neuter" number="plural"

case="genitive" $>$ прав $</$ noun $>$

$<$ conjunction subtype $=$ "coordinating" $>i</$ conjunction $>$

$<$ noun subtype="common" gender="feminine" number="plural"

case $=$ "genitive" $>$ свобод </noun>

$<$ noun subtype="common" gender="feminine" number="singular"

case $=$ "genitive" $>$ людини $</$ noun $>$

$<$ conjunction subtype $=$ "coordinating" $>i</$ conjunction $>$

$<$ noun subtype="common" gender="masculine" number="singular"

case="genitive" >громадянина </noun>

$<$ adverb $>$ безпосередньо</adverb $>$

$<$ preposition case="locative" $>$ Ha $<$ /preposition $>$

$<$ noun subtype="common" gender="feminine" number="singular"

case $=$ "locative" $>$ nidcmaвi</noun $>$

$<$ noun subtype="common" gender="feminine" number="singular"

case $="$ genitive" $>$ Констumyuiï $<$ /noun $>$

$<$ noun subtype="proper" gender="feminine" number="singular"

case $=$ "genitive" $>$ україни $</$ noun $>$

$<$ verb subtype="personal" aspect="imperfective" tense="present"

mood="indicative" voice="passive" person="third">гаранmyєmься </verb> $<$ stop $>$. $<$ stop $>$

$</$ body $>$

Той самий текст 3 промаркованими двосимвольним кодом словоформами:

$<b o d y>$

$<$ noun code $=$ "FA" $>$ Конституція $</$ noun $>$

$<$ noun code $=" G B ">$ Ураїни $</$ noun $>$

$<$ verb code $=" U O^{\prime \prime}>$ Ma $\epsilon$ < verb $>$

$<$ adjective code="AJ"> найвищу $</$ adjective $>$

$<$ adjective code="AJ">юридичну</adjective $>$

$<$ noun code $=$ " $F D$ " $>$ cuлy $</$ noun $>$

$<$ stop $>$. $</$ stop $>$

$<$ noun code $=$ "MH" $>$ Закони $</$ noun $>$

$<$ conjunction code $=$ "SC" $>$ ma $</$ conjunction $>$

$<$ pronoun code $=" R S^{\prime \prime}>$ iHui $</$ pronoun $>$

$<$ adjective code="AS">нормативно-правові</adjective $>$

$<$ noun code $=" M H^{\prime \prime}>$ akmu $</$ noun $>$

$<$ verb code="YP">приймаються</verb>

$<$ preposition code $=" P F ">$ Ha $</$ preposition $>$

$<$ noun code $=$ "FF" $>$ ОСновi $</$ noun $>$

$<$ noun code $=" F B ">$ Конституuіï $<$ /noun $>$

$<$ noun code $=" G B ">$ Ураїни $</$ noun $>$

$<$ conjunction code $=$ "SC" $>i</$ conjunction $>$

$<$ adjective code="AS">повинні</adjective >

$<$ verb code ="UA">відповідаmu</verb>

$<$ pronoun code $=$ "OI">ï̈ </pronoun $>$

$<$ stop $>$. $<$ stop $>$ 


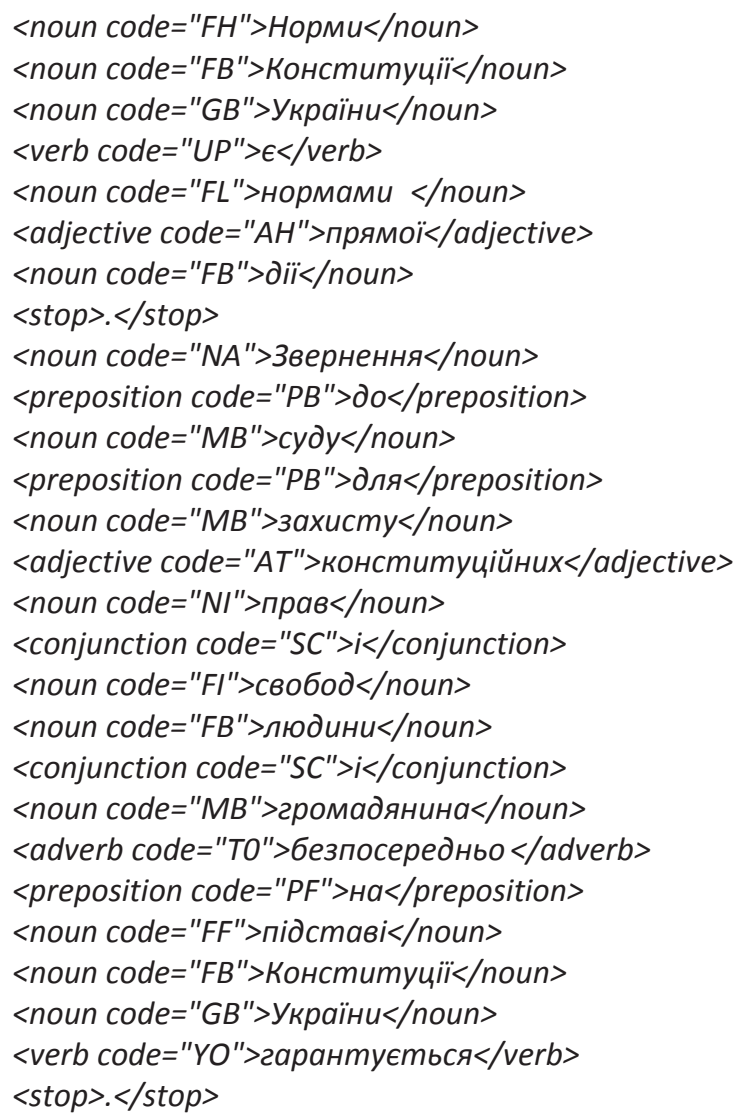

Повний лексичний опис УНЛК передбачає включення інших рівнів опису тексту: синтаксичного, семантичного та ін.

Зауважимо, що виходячи 3 нагальних потреб та цілей, маємо певні складності, обумовлені обмеженістю можливостей визначення типу документів у форматі DTD. Так, у текстах реальної складності мають місце випадки, коли один елемент тексту може бути віднесеним до різних тегів. Тому є сенс у створенні спеціалізованих мов маркування. Інша проблема, пов'язана з форматом DTD, полягає у відсутності можливості контролювати контекст вкладання тегів (тобто визначення допустимих вкладень в залежності від попередніх). Ця проблема певною мірою вирішується при визначенні схеми документа інструментами XSD.

\subsection{2. Морфологічне маркування УНЛК}

У цьому пункті підрозділу описуються розроблені у Фонді морфологічні аналізатори, моделі та системи морфологічного аналізу української мови, що застосовуються до морфологічного маркування УНЛК. Зазначені морфологічні аналізатори реалізують алгоритми аналізу, лематизації та синтезу текстових 
одиниць, які передбачають використання електронного граматичного словника (ЕГС) української мови.

Зазначимо, що існують й інші підходи до побудови морфологічних модулів: наприклад, імовірнісний підхід (стемінг) ${ }^{80}$, а також підхід на основі емпіричних формул $^{81}$. Згадані підходи хоча і більш прості й певною мірою більш гнучкі, але, як відзначають самі автори, мають істотний недолік - нижчу точність, ніж у традиційних методів, які грунтуються на великих морфологічних словниках із застосуванням граматичних / морфологічних правил. Крім того, на нашу думку, такі підходи не є універсальними, застосованими до будь-якої мови, а тільки для мови із простою системою словозміни (наприклад, англійської). Для мов флективних найбільш доцільно використовувати алгоритми аналізу, синтезу, лематизації, які будуються на використанні електронних граматичних словників, $\mathrm{i}$ тут покладаємося саме на цей принцип. Тому спочатку подамо докладний виклад формальних та технологічних засад створення ЕГС, а потім наведемо алгоритми морфологічного аналізу та синтезу, які базуються на застосуванні електронних граматичних словників.

\subsubsection{1. Структура бази даних ЕГС}

БД електронного граматичного словника флективної мови репрезентується реляційною моделлю та структурно складається з таких таблиць:

- таблиця «nom» реєстрових одиниць 'Reestr';

— таблиця квазіфлексій «flex», в якій для кожної граматичної форми (поле 'NumbOfGrForm') кожного парадигматичного класу (поле 'type') задані квазіфлексії 'flex';

- таблиця «indent», що задає параметри та характеристики, які $\epsilon$ однаковими для кожного з парадигматичних класів;

— таблиця «parts» лексико-граматичних класів та їхніх кодів;

— таблиця «gr» словозмінних типів;

— таблиця наголосів «accent».

Перелічені таблиці з описом полів для БД ЕГС української мови наведено нижче.

${ }^{80}$ Коваленко А. Вероятностный морфологический анализатор (стеммер). URL: http://www.keva.ru/stemka/stemka.html; Porter M. An Algorithm for Suffix Stripping. Program, 1980. \#14. P. 130-137.

${ }^{81}$ Макагонов П., Александров М, Гельбух А. Формулы проверки подобия слов с обучением на примерах: построение и применение. Корпусная лингвистика - 2004. Труды междун. конф. Санкт-Петербург. С. 239-255. 
舍

\begin{tabular}{|c|c|c|c|c|c|c|c|c|c|}
\hline ұนәวоV & 0 & o & 0 & 0 & o & lo & 0 & 0 & 0 \\
\hline щшоэ & & & 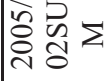 & & & & & & \\
\hline யəવqо. dSI & 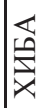 & 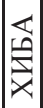 & 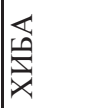 & 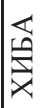 & 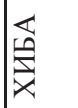 & 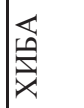 & 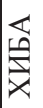 & 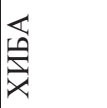 & 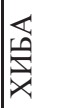 \\
\hline 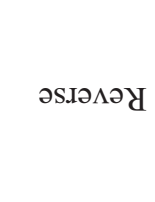 & $\overline{0}$ & $\overline{0}$ & $\overline{0}$ & 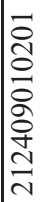 & 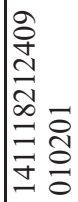 & 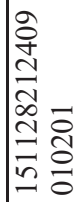 & 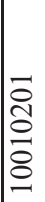 & 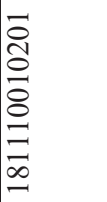 & 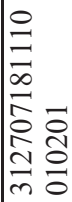 \\
\hline$\partial \Lambda\lfloor\rceil \vee \forall S I$ & 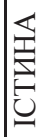 & 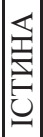 & $\underset{\Xi}{\Xi}$ & $\underset{\Xi}{\Xi}$ & $\underset{\underbrace{}}{\stackrel{\Xi}{\Xi}}$ & 災 & $\underset{\Xi}{\Xi}$ & $\underset{\Xi}{\Xi}$ & $\underset{\Xi}{\Xi}$ \\
\hline [P्CSI & 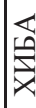 & 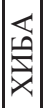 & 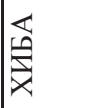 & 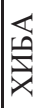 & 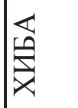 & 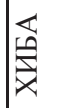 & 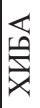 & 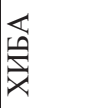 & 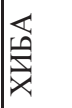 \\
\hline әңеव & 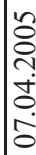 & 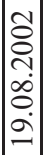 & 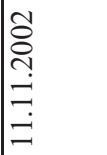 & 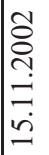 & 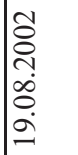 & 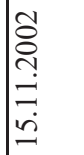 & 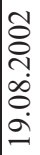 & 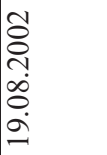 & 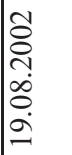 \\
\hline $\mathrm{UM}_{\mathrm{N}}$ & 0 & $\sim$ & 0 & 0 & 0 & 0 & 0 & 0 & 0 \\
\hline $\mathrm{plo}^{-}$шоо N & - & $\mathrm{N}$ & m & $\ln$ & 6 & r & $\infty$ & $a$ & 으 \\
\hline moN & - & $\sim$ & $m$ & in & 6 & $r$ & $\infty$ & $a$ & 으 \\
\hline ไ!̣ి!̣̂ & $\overline{0}$ & $\overline{0}$ & $\overline{0}$ & 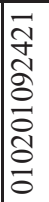 & 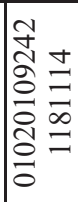 & 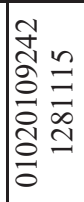 & 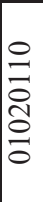 & 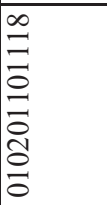 & 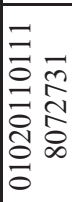 \\
\hline$\angle \mathrm{P}[\partial ! \mathrm{H}$ & & & & & & & & & \\
\hline 9рाอ! & & & & & & & & & \\
\hline sp[ə!⿱ & & & & & & & & 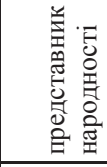 & \\
\hline əd $\kappa_{L}$ & 0 & o & 10 & 8 & 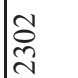 & $\stackrel{0}{2}$ & 8 & $\stackrel{0}{2}$ & 早 \\
\hline $\mathcal{H I P}_{\mathrm{d}}$ & 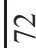 & $\approx$ & 咅 & $\infty$ & $=$ & $\infty$ & $\infty$ & - & $r$ \\
\hline zрџә!н & - & $\sim$ & $m$ & 0 & & lo & & & \\
\hline 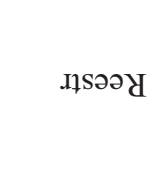 & $\varangle$ & $\varangle$ & $\ll$ & 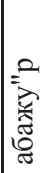 & 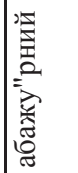 & 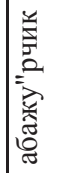 & ") & 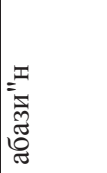 & 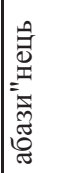 \\
\hline$\theta$ & - & $\sim$ & $m$ & in & 0 & $r$ & $\infty$ & $a$ & 우 \\
\hline
\end{tabular}




\section{Поля таблииі «nom»:}

Назва поля

ID

Reestr

Field2

part -

type -

Field5

Field6

Digit

Nom

nom_old

Own

Date

IsDel

IsActive

Reverse

IsProblem

acomm

accent

\section{Bмiсm}

Унікальний ідентифікатор запису.

Реєстрова одиниця.

Номер омонімії (0 - у разі відсутності омонімів).

Частина мови (з таблиці «Parts»).

Номер парадигматичного класу.

Семантичний коментар.

Стилістичний коментар.

Реєстрова одиниця у вигляді цифрового коду (використовується для сортування).

Зарезервовано

Унікальний ідентифікатор слова для створення файла gram.dic.

Ознака, чи є слово власною назвою; також зберігає властивості сполучників та прийменників.

Дата останньої зміни слова.

Ознака вилучення слова.

Ознака, чи є слово активним.

Реєстрові одиниці у вигляді зворотного цифрового коду (для сортування й створення інверсного словника).

Ознака, чи є слово проблемним.

Робочий коментар для внутрішнього використання.

Номер класу наголосів.

Таблицю проіндексовано за полями: 'ID (unique)'; 'Reestr'; 'Field2'; 'part'; 'type'; 'Digit'; 'Nom'; 'nom_old'; 'own'; 'acomm'.

Таблиця квазіфлексій «flex»

\begin{tabular}{|c|c|c|c|c|c|c|}
\hline ID & flex & Field2 & xmpl & Field4 & type & part \\
\hline 37571 & іль & 1 & & & 2132 & 1 \\
\hline 37572 & олі & 2 & & & 2132 & 1 \\
\hline 37573 & олі & 3 & & & 2132 & 1 \\
\hline 37574 & іль & 4 & & & 2132 & 1 \\
\hline 37575 & іллю & 5 & & & 2132 & 1 \\
\hline 37576 & олі & 6 & & & 2132 & 1 \\
\hline 37577 & оле & 7 & & & 2132 & 1 \\
\hline
\end{tabular}

\section{Поля таблиці «flex»:}

\section{Назва поля}

ID

Flex

Field2

Xmpl

Field4

Type

Part

\section{Bмicm}

Унікальний ідентифікатор запису.

Квазіфлексія.

Номер граматичного значення.

Приклад слова.

Зарезервовано

Номер парадигматичного класу.

Частина мови.

Таблицю проіндексовано за полями: 'ID (unique)'; 'Field2'; 'type'; 'part'. 
Таблиця «indent»

\begin{tabular}{|c|c|c|c|c|c|c|}
\hline ID & type & indent & Field3 & Field4 & comment & intcomm \\
\hline 2130 & 2130 & 3 & 2 & 1 & & 0 \\
\hline 2131 & 2131 & 3 & 2 & 1 & & 0 \\
\hline 2132 & 2132 & 3 & 0 & 0 & & 0 \\
\hline 2133 & 2133 & 4 & 0 & 0 & & 0 \\
\hline 2134 & 2134 & 1 & 0 & 0 & & 0 \\
\hline 2135 & 2135 & 1 & 0 & 0 & & 0 \\
\hline
\end{tabular}

\section{Поля таблииі «indent»}

Назва поля

ID

Type indent

Field3

Field4

comment intcomm

\section{Bмiсm}

Унікальний ідентифікатор запису.

Номер парадигматичного класу.

Відстань у літерах від кінця слова до квазіоснови (наприклад: «дивовижність», tуре - 2130; квазіоснова - «дивовижн», квазіфлексія «ість»).

Номер літери від початку квазіфлексії, з якої починається незмінна частина квазіфлексії (наприклад: «дивовижність», tуре - 2130; квазіфлексія - «ість», незмінна частина починається 3 «с»)).

Відстань у літерах від початку квазіфлексії (поле 'Field3') до незмінної частини квазіфлексії (наприклад: «дивовижність», tyре - 2130; квазіфлексія «ість», незмінна частина починається з другої літери - «с», незмінна частина квазіфлексії - «ст»).

Граматичний коментар до парадигматичного класу.

Зарезервовано

Таблицю проіндексовано за полями: 'ID (unique)'; 'type'; 'comment'; 'intcomm'.

Таблиця наголосів «accent»

\begin{tabular}{|c|c|c|c|c|c|c|c|c|}
\hline ID & indent1 & indent2 & indent3 & indent4 & accent_type & part & gram & xmpl \\
\hline 779 & 0 & -2 & & & 37 & & 15 & загнистися \\
\hline 780 & 0 & -2 & & & 37 & & 16 & \\
\hline 781 & 0 & 255 & & & 37 & & 19 & \\
\hline 782 & 0 & -1 & & & 37 & & 20 & \\
\hline 783 & 0 & -1 & & & 37 & & 21 & \\
\hline 784 & 0 & -1 & & & 37 & & 22 & \\
\hline 785 & 0 & 255 & & & 37 & & 26 & \\
\hline
\end{tabular}

\section{Поля таблиці «accent»:}

Назва поля

ID

indent1

indent2

\section{Bмicm}

Унікальний ідентифікатор запису.

Кількість позицій, на які потрібно змістити перший наголос слова 3 тої позиції, яку він займає в початковій формі (0 - якщо наголос не міняє позиції; 255 якщо наголос зникає).

Те саме для другого наголосу (якщо в початковій формі другого наголосу не було, то його позиція в певній формі відраховується від позиції першого 


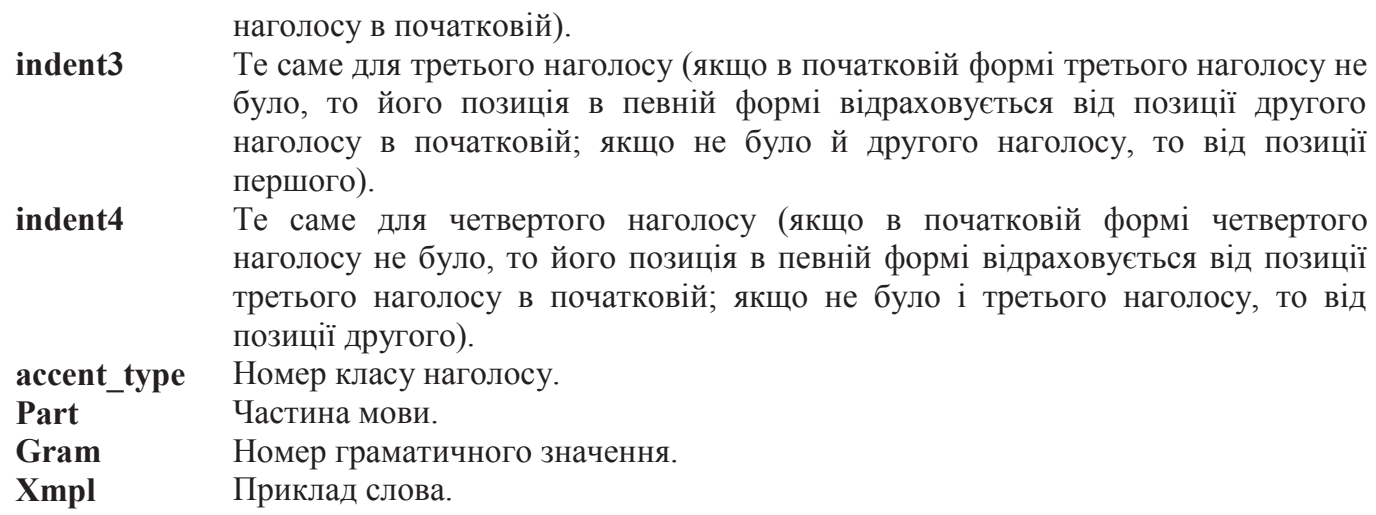

Таблицю проіндексовано за полями: 'accent_type'; 'gram'.

Таблиця граматичних значень «gr»

\section{Поля таблииі «}

Назва поля

Number of table

Код частини мови.

Part of speech Назва частини мови.

Field4, Field5,..., Значення граматичних категорій (граматичне значення).

Field29

\section{Таблиця граматичних класів «Parts»}

\section{Поля таблиці «Parts»}

\begin{tabular}{ll} 
Назва поля & \multicolumn{1}{c}{ Вміст } \\
ID & Унікальний ідентифікатор запису - код частини мови. \\
Part & Скорочена назва частини мови. \\
Com & Повна назва частини мови. \\
Ac & Коментар.
\end{tabular}

Таблицю Parts проіндексовано за полями: ‘ID (unique)'; 'com'.

Між полями 'Number of table' таблиці «gr» та 'ID' таблиці «Parts» існує відповідність.

Також до граматичної ЛБД входить таблиця «TYP_REFL», що складається з одного поля 'tуре' та містить перелік рефлексивних дієслівних парадигматичних класів. 


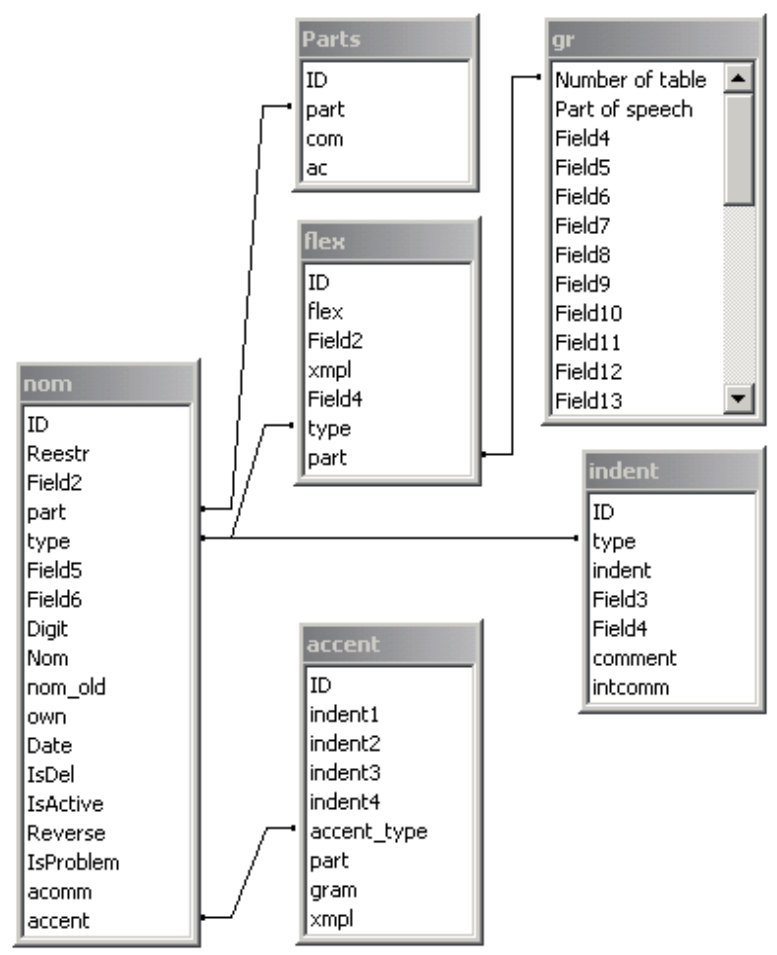

Рис. 19.5. Зв’язки між таблицями граматичної ЛБД української мови

Схема зв'язків між таблицями граматичної ЛБД української мови, наведена на рис. 19.5, є спрощеною: вона не відображає непрямі зв'язки, які існують між полями 'Field2' таблиці «flex» та 'gram' таблиці «accent» до полів 3 4-го до 29-е ('Field4' - 'Field29') таблиці «gr».

Структура БД ЕГС російської мови є аналогічною до структури БД ЕГС української мови. Відмінність полягає у кодуванні частин мови та граматичних значень, а також у зв’язках між таблицями «gr» та «Parts».

\subsubsection{2. Програмні засоби граматичної ЛБД}

Для роботи з граматичною ЛБД було створено клієнтську програму для іï редагування, що підтримує такі функції:

- перегляд реєстру граматичного словника, повної парадигми та транскрипції кожного слова;

- перехід до російського словника;

- сортування в прямому або інверсному режимі;

- фільтрування реєстру: за частинами мови, за парадигматичними класами, за омонімами, за власними назвами, за складеними словами, за 
активними / неактивними та

одиницями, за довільним запитом;

- пошук слів в реєстрі;

- додавання, вилучення та редагування реєстрових слів;

- додавання, вилучення та редагування парадигматичних класів та флексій в парадигматичних класах;

— запис у файл реєстрових одиниць або статей;

- перевірка наголосів;

- створення граматичного файлу gram.dic.

Робоче вікно програми наведено на рис. 19.6.

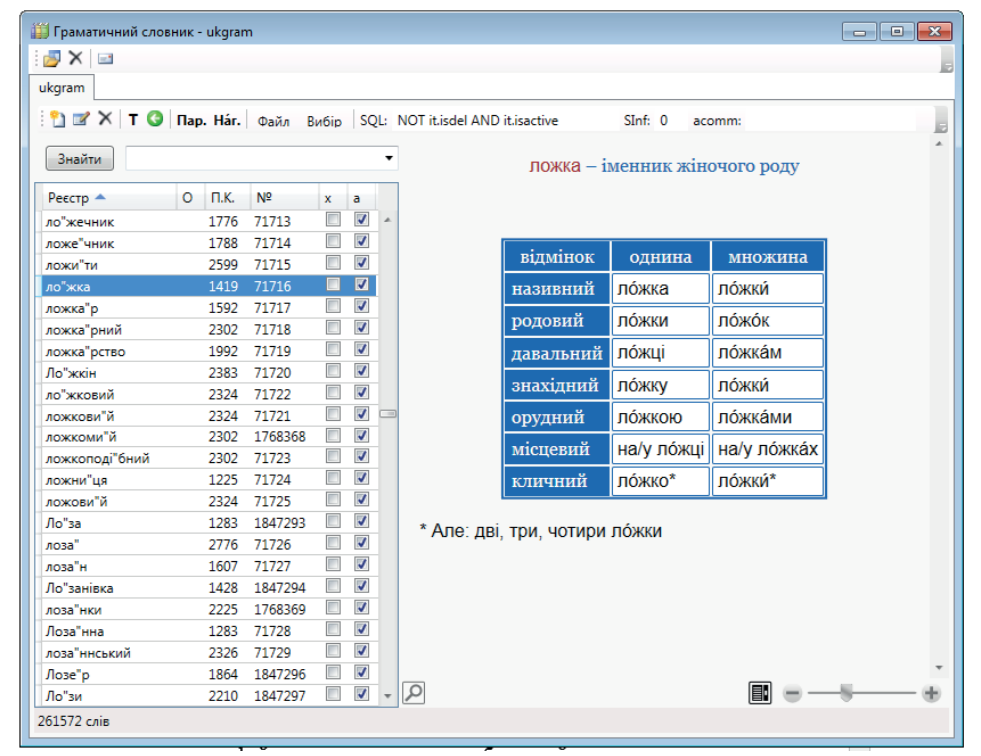

Рис. 19.6. Робоче вікно програми для роботи з ЛБД української мови

Структура описаної вище граматичної ЛБД $\epsilon$ досить зручною для формування ЛБД та іiі редагування, але вимагає значних обчислювальних потужностей та займає багато дискового простору, що не завжди забезпечує клієнтський комп'ютер, особливо в локальному режимі. Тому було розроблено оптимізовану ЛБД, яку реалізує файл типу gram.dic, а також бібліотека функцій для роботи з файлом такої структури (wpar01.dll) ${ }^{82}$. Ця бібліотека може динамічно під’єднуватися до зовнішньої програми (ІЛС «Словники України», ЛК тощо).

Розглянемо більш детально процедуру створення граматичного файлу gram.dic. Цей файл складається з чотирьох послідовно записаних компонент:

- розмір компоненти 1 (ціле, 4 байти);

— компонента 1;

— розмір компоненти 2 (ціле, 4 байти);

${ }^{82}$ Автор - Рабулець О. Г. 
— компонента 4;

На проміжному етапі ці компоненти записуються у файли base.wrd (1), base.prm (2), flex.wrd (3) та flex.prm (4), а потім інтегруються в єдиний файл. Розглянемо їхню внутрішню структуру:

1. Квазіоснови:

1.1. Кількість квазіоснов (ціле, 4 байти).

1.2. Номер версії (Unicode, 6 байтів); якщо для нумерації квазіоснов використовується поле 'nom_old', то в номері версії замість крапки проставляється двокрапка (наприклад, "1:0").

1.3. Службова інформація, яка визначається режимом фільтрації реєстру (Unicode, 10 байтів):

1.3.1. "_all" - всі слова, крім вилучених;

1.3.2. "_adel" - взагалі всі слова;

1.3.3. "_del" - тільки вилучені слова;

1.3.4. "__act" - активні, не вилучені слова;

1.3.5. "_nact" - не активні, не вилучені слова;

1.3.6. "dnact" - не активні, вилучені слова;

1.3.7. "__ _ - інше.

1.4. Дата створення файлу (у форматі ‘ддммрр’, Unicode, 12 байтів).

1.5. Квазіоснови (Unicode), що закінчуються на $\backslash 0$; записуються 3 поля 'Reestr' таблиці «nom».

1.6. Незмінні частини квазіфлексій (Unicode), що закінчуються на $\backslash 0$; формуються $з$ поля 'Reestr' таблиці «nom» 3 використанням даних таблиці «indent».

Пункти 1.5 та 1.6 повторюються до кінця компоненти.

2. Параметри квазіоснов:

2.1. Реєстровий ідентифікатор (ціле, 4 байти); записується з поля 'nom_old' таблиці «nоm».

2.2. Номер лексичного омографа (ціле, 1 байт); записується з поля 'Field2' таблиці «nom».

2.3. Частина мови (ціле, 1 байт); записується 3 поля 'part' таблиці «nom». Номер парадигматичного класу (ціле, 2 байти); записується 3 поля 'tуре' таблиці «nom».

2.4. Додаткова інформація (ціле, 1 байт):

2.4.1. для активних слів: у сьомий біт записується 1 (х1хxxxхx) (визначається режимом фільтрації реєстру);

2.4.2. для дієслів: двовидових - у перший біт записується 1 (хxхxхxx1) (визначається частиною мови 3 поля 'part' 3 таблиці «nom»); рефлексивних - у восьмий біт записується 1 (1 хxххххx) (визначається таблицею «TYP_REFL»); 
2.4.3. для власних назв: антропонім - 2, топонім - 3, присвійний -4 , абревіатура - 5; записується з поля 'own' таблиці «nom».

2.4.4. для сполучників: підрядний - 1 , сурядний - 2, суряднопідрядний - 3; записується з поля 'own' таблиці «nom».

2.4.5. для прийменників: керує знахідним відмінком - 1 біт (1), керує давальним відмінком - 2 біт (2), керує місцевим відмінком - 3 біт (4), керує родовим відмінком - 4 біт (8), керує орудним відмінком -5 біт (16); записується з поля 'own' таблиці «nom».

2.5. Інформація з поля 'Nom’ таблиці «nom» (ціле, 4 байти).

3. Квазіфлексіі:

3.1. Кількість парадигматичних класів (ціле, 4 байти); визначається динамічно.

3.2. Службова інформація (аналогічно 1.2-1.4, 28 байтів).

3.4. Кількість флексій в класі (ціле, 1 байт); визначається динамічно.

3.4. Частина мови (ціле, 1 байт); записується з поля 'part' таблиці «flex».

3.5. Флексії (Unicode), що закінчуються на $\backslash 0$ - стільки, скільки граматичних значень має парадигматичний клас; записуються з поля 'flex' таблиці «flex», при цьому символи «*», «^», «\%», «\$», «\&» та «@» вилучаються.

Кількість повторень пунктів 3.3-3.5 відповідає кількості парадигматичних класів.

4. Параметри квазіфлексій:

4.1. Номер граматичного значення для частини мови (ціле, 1 байт); записується з поля 'Field2'таблиці «flex».

4.2. Якщо флексія закінчується на «*», то в перший біт записується 1 (xxxxxx1); якщо флексія закінчується на «^» (не відображати), то в другий біт записується 1 (xxxxx1x); якщо флексія закінчується на «\%» (по ), то в третій біт записується 1 (хxхxх1хx); якщо флексія закінчується на «\$»(на), то в четвертий біт записується 1 (xxxx1xxx); якщо флексія закінчується на «\&» (по), то в п'ятий біт записується 1 (xxx1xxxx); якщо флексія закінчується на «@» (до), то в шостий біт записується 1 (хx1хxхxх).

Крім файлу gram.dic, створюється також індексний файл act.ind, в який записується кількість активних слів (ціле, 4 байти), а також перелік їхніх реєстрових ідентифікаторів (з поля 'nom_old' таблиці «nom», ціле, 4 байти). Неактивними є деякі рідковживані, діалектні та інші слова, що не входять до головного реєстру словника, але мають враховуватися при лематизації та інших процедурах аналізу тексту з використанням gram.dic. Файл act.ind доцільно використовувати при створенні файлу gram.dic в режимі фільтрації реєстру 1.3.1 ("_all" - всі слова, крім вилучених) або 1.3.2. ("_adel" - взагалі всі слова).

Опис принципів побудови алгоритмів морфологічного аналізу ЛК, синтезу парадигми конкретного слова та лематизації текстових словоформ з використаням 
ЕГС російської мови можна знайти в матеріалах міжнародної конференції «Корпусная лингвистика и лингвистические базы данных-2002». ${ }^{83}$

Модуль морфологічного аналізу працює зі структурно розміченим текстом, в якому вже визначені й проставлені теги для: початку і кінця речення, іншомовних слів, цифр, рубрикаторів, дат, електронних адрес, власних імен тощо. Програма морфологічного аналізу працює на рівні речень. Результатом роботи програми морфологічного аналізатора $є$ приписаний кожній словоформі аналізованого речення код (неомонімічній - двосимвольний: <частина мови, граматичне значення>, омонімічній - ланцюжок кодів, що відображає іiі граматичну омонімію) ${ }^{84}$.

Продемонструємо роботу програми морфологічного маркування тексту на прикладі МА російського тексту (рис. 19.7).

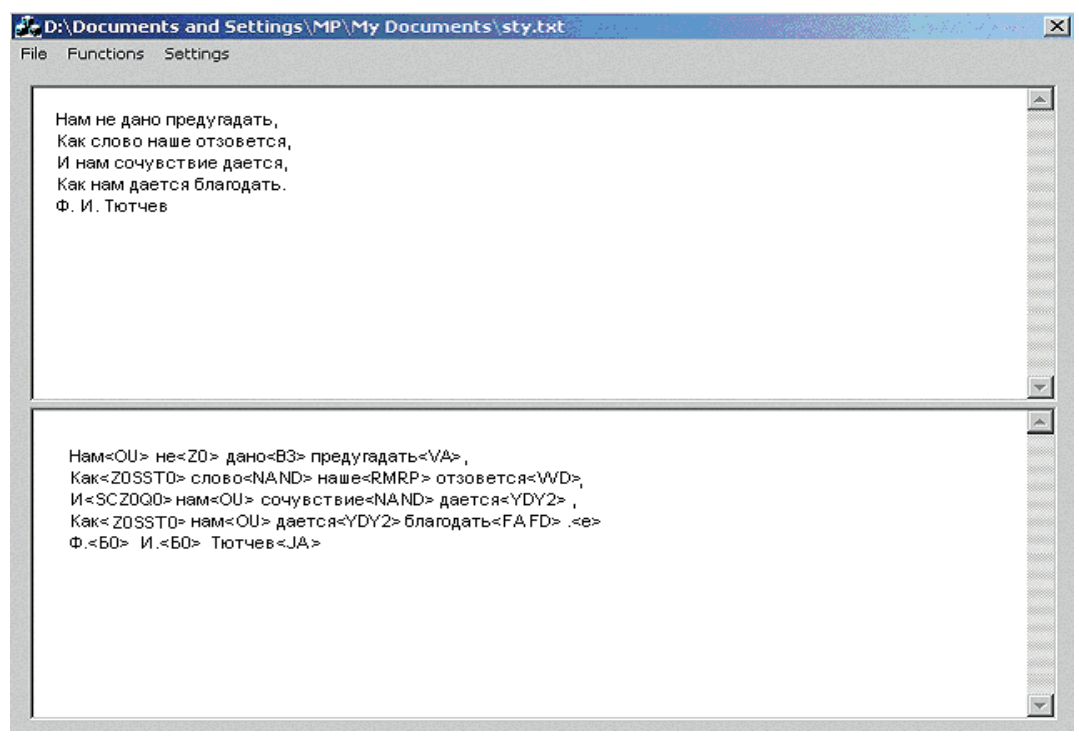

Рис. 19.7. Робоче вікно програми МА з виведеним аналізованим текстом та результатом морфологічного аналізу

При обранні користувачем мови вхідного тексту (російська або українська), автоматично підключається відповідний граматичний словник, що буде використовуватись програмою МА.

Передбачено три режими роботи програми морфологічного аналізатора:

${ }^{83}$ Грязнухина Т. А., Любченко Т. П., Рабулец А. Г. Электронная версия грамматического словаря русского языка (А. А. Зализняк) как инструмент автоматического морфологического анализа русского текста. Корпусная лингвистика и лингвистические базы данных. Доклады научн. конф. С.-Петербург: изд-во С.-Петерб. ун-та, 2002. С. 63-70.

${ }^{84}$ Алгоритми контекстного аналізу розроблені Т. О. Грязнухіною. 
1) морфологічний аналіз файлу без відображення його тексту в робочому вікні. В результаті формується файл $\mathbf{m r f}{ }^{*} . \mathbf{t x t} 3$ морфологічно розміченим текстом;

2) морфологічний аналіз файлу з виводом результату в робочому вікні для перегляду користувачем після закінчення роботи програми МА;

3) морфологічний аналіз тексту, що безпосередньо вводиться або завантажується 3 файлу користувачем у робоче вікно. Аналізовний текст відображається у верхньому полі робочого вікна, результат МА - в нижньому полі. На рис. 19.7 наведено робоче вікно програми МА при роботі у цьому режимі.

Результат роботи програми МА російського тексту, наведеного у нижній зоні робочого вікна (рис. 19.7) з розписаними кодами (записується в окремий файл):

Нам<OU $>=\{$ мы: местоимение, дательный падеж $\}$

не $<Z O>=\{$ не: частица $\}$

дано<В3> = \{данный: причастие, с.р., краткая форма\}

предугадать<VA> = \{предугадать: глагол совершенного вида, инфинитив ,

Как<ZOSSTO> = \{как: частица; союз подчинительный; наречие $\}$

слово<NAND> = \{слово: существительное с.р., ед.число, именительный падеж;

существительное с.р., ед.ч., винительный падеж\}

наше $<\mathrm{RMRP}>=$ = наш: местоимение-прилагательное, с.р., ед.ч., именит.

падеж; местоимение-прилагательное, с.р., ед.ч., винит. падеж\}

отзовется $<\mathrm{WD}>=$ \{отозваться: глагол совершенного вида, будущее время, 3лицо, ед.ч.\},

И<SCZOQ0>= \{и: союз сочинительный; частица; междометие $\}$

нам $\langle\mathrm{OU}\rangle=$ \{мы: местоимение, дательный падеж\}

сочувствие<NAND>= \{сочувствие: существительное с.р., ед.число,

именительный падеж; существительное с.р., ед.ч., винительный падеж\}

дается<YDY2>= \{даваться: глагол несовершенного вида, возвратный, настоящее время, 3 л., ед. ч.; давать: глагол несовершенного вида, страд. форма на -ся, настоящее время, 3-е лицо, ед. число\},

Как<ZOSSTO>= \{как: частица; союз подчинительный; наречие $\}$

нам $\langle\mathrm{OU}>=$ \{мы: местоимение, дательный падеж\}

дается<YDY2> = \{ даваться: глагол несовершенного вида, возвратный, настоящее время, 3 л., ед. ч.; давать: глагол несовершенного вида, страд. форма на -ся, настоящее время, 3-е лицо, ед. число\}

благодать $\angle F A F D>=\{$ благодать: существительное ж.р., ед.ч., именит.падеж;

существительное ж.р., ед.ч., винит.падеж\} .<е>

Ф. $\angle Б 0>=\{$ инициал $\}$

И. $\langle$ БО $>=\{$ инициал $\}$

Тютчев $<\mathrm{A}>=\{$ Тютчев: имя собственное, м.р., ед. число, именительный падеж\} 
Створені граматичні ЛБД української та російської мов функціонують під системою керування БД Microsoft SQL Server 2016. Програму MA розроблено в середовищі Microsoft Visual Studio 2017.

Значення автоматичного морфологічного аналізу, синтезу і лематизації для прикладних лінгвістичних (i не тільки) досліджень переоцінити важко. Морфологічний модуль потрібен в орфографічних коректорах, в системах оптичного розпізнавання символів, в системах машинного перекладу, в системах штучного інтелекту. Особливе значення морфологічний аналіз має для мов флективних, до яких належать індоєвропейські та семіто-хамітські мови, число носіїв яких у світі, за приблизними оцінками, сягає 2,85 млрд осіб. Кількість різних словоформ у цих мовах $є$ настільки великою, що зберігати граматичну інформацію у вигляді словників словоформ вбачається недоцільним (якби й розвиток обчислювальної техніки і спонукав би до цього).

Важливим компонентом сервісної системи ЛК є лематизатор - програма, що ставить у відповідність кожній словоформі тексту іiі початкову форму (лему). Лематизація не тільки спрощує формулювання пошукових запитів, зменшує «шум» при побудові конкордансів, але й дозволяє отримати реєстр словникового типу (рос. «словник»). Тобто, у користувача з'являється можливість згенерувати масив слів із прикладами (фактично отримати матеріал для словника, у якому вже будуть позначені словникові статті, що складатимуться 3 «лексичного входу», граматичного опису і множини ілюстрацій).

\subsection{3. Синтаксичне маркування ЛК}

На сьогодні синтаксично анотовані ЛК є рідкісним явищем у корпусній лінгвістиці, при тому, що потреба в таких корпусах є очевидною. Синтаксично маркований ЛК слугує підгрунтям лінгвістичних досліджень у сфері синтаксису, зокрема, функціонального та комунікативного, виступає джерелом мовного матеріалу для розробників комп'ютерних мовно-орієнтованих систем (насамперед, машинного перекладу та автоматичного редагування), при укладанні алгоритмів морфосинтаксичного аналізу - в тій його частині, що стосується зняття граматичної омонімії текстових одиниць - синтаксичного та семантикосинтаксичного аналізів, а також базою для створення комп'ютерної граматики. Зрештою, коло завдань синтаксичного, так само як i інших різновидів лінгвістичного аналізу, певне, що необмежене.

Основним завданням синтаксичного маркування природномовних текстів $\epsilon$ визначення синтаксичних функцій всіх текстових одиниць (розділових знаків, слів, словосполучень тощо). Зазначимо, що на сьогодні найбільшою синтаксичною одиницею тексту, результати автоматичного синтаксичного маркування якої мають прийнятний результат, є речення. Система синтаксичних тегів (міток) забезпечує виділення в реченні синтаксично зв'язаних слів 3 
вказівкою типу зв'язку між ними, для розділових знаків - визначення синтаксичного зв'язку, в організації якого вони беруть участь - на рівні слів, синтаксичних конструкцій (вставні слова, відокремлені звороти), предикативних частин речення.

Для корпусів текстів аналітичних та флективно-аналітичних мов формою представлення синтаксичної структури речення обирається структура безпосередніх складників, для флективних мов - дерево залежностей. Саме в такий спосіб синтаксично анотуються, наприклад, корпус Карлового університету (Чехія), корпус Інституту проблем передання інформації РАН (РФ), корпус «ЦЛД - МДУ» (сумісний проект Центру лінгвістичної документації та відділення теоретичної та прикладної лінгвістики філологічного факультету МДУ імені М. В. Ломоносова) $(\mathrm{P} \Phi)^{85}$. Аналогічний підхід обрано й для синтаксичного маркування УНЛК в Українському мовно-інформаційному фонді.

Синтаксичний аналізатор (СА), що розробляється у Фонді для української мови в системі багатомовного МП, включається 3 певними модифікаціями в програмно-лінгвістичне забезпечення УНЛК, призначене для лінгвістичного маркування. Теоретичні засади побудови синтаксичного аналізатора грунтуються на загальних принципах (положеннях) автоматичного синтаксичного аналізу, розроблених у відділі структурної, математичної та прикладної лінгвістики Інституту мовознавства ім. О. О. Потебні ще в 90-ті роки минулого століття у межах системи автоматичного аналізу російського тексту ${ }^{86}$. За цими принципами лінгвістичний аналіз синтаксичної структури українського речення здійснюється за впорядкованими правилами перетворення лінійної морфологічної структури речення на двомірну поверхнево-синтаксичну, відтворену у вигляді дерева залежностей (ДЗ). У ДЗ знаходять своє відображення як синтаксичні зв'язки між словами речення (вершинами дерева), так і між певними його синтаксичними конструкціями (гілками Д3), а у випадку складного речення - між його предикативними частинами.

Щодо згаданих вище модифікацій, яких зазнає синтаксичний аналізатор при використанні його для синтаксичного маркування УНЛК, то вони пов'язані, поперше, з дещо іншим характером вихідних даних, на яких працює аналізатор в

${ }^{85}$ Кустова Г. И., Плунгян В. А. Краткое описание проекта «Русский стандарт» «Диалог2002»; Аннотированный корпус русских текстов: концепция инструменты разметки, типы информации. / И. М. Богуславский и др. Труды Международного семинара по компьютерной лингвистике и ее приложениям «Диалог-2000», 2000.; Сичинава Д. В. К задаче создания корпусов русского языка; Разработка синтаксически размеченного корпуса текстов. //Доклады научной конференции / И. М. Богуславский и др. Корпусная лингвистика и лингвистические базы данных. С.-Петербург, 2002. С. 40-50; Hajichova E., Panevova J., Sgall P. Language Resources Need Annotations To Make Them Really Reusable: The Prague Dependency Treebank. The first International Conference on Language Resources and Evaluation, 1998; Ножов И. М. Процессор синтаксической сегментации русского предложения. НТИ. Серия 2. Информационные процессы и системы. № 11, 2003. С. 26-37.

${ }^{86}$ Синтаксический анализ научного текста на ЭВМ / Т. О Грязнухіна та ін. Київ: Наукова думка, 1999. С. 272. 
КТ: в системі машинного перекладу ними $є$ результати автоматичного контекстного аналізу, після якого певна частина омонімічних кодів (зазвичай, це слова 3 дистантними зв'язками у реченні) залишається в тексті, i тому правилами алгоритму передбачається зняття граматичної омонімії за синтаксичним контекстом. Текст, на якому здійснюється синтаксичне маркування, після проведення на ньому автоматичного морфологічного маркування обов'язково підлягає постредагуванню лінгвістами, після чого всі слова одержують однозначні коди. Звичайно, це певною мірою спрощує алгоритм синтаксичного аналізу, але передбачення етапу постредагування результатів автоматичного синтаксичного маркування (наголошуємо, що йдеться про великі обсяги текстів) потребує певних змін у стратегії проведення синтаксичного аналізу - повне дерево залежностей будується для тих речень, для яких за алгоритмом вдається знайти однозначне визначення їхніх структур - в іншому разі речення позначається як таке, що потребує уваги лінгвістів (для зручності укладачів сервісні програми корпусу підтримують режим перегляду лише цих позначених речень). Крім того, при синтаксичному маркуванні тексту передбачається приписування синтаксичних параметрів безпосередньо словоформам (як це робиться при морфологічному маркуванні) посередництвом синтаксичних кодових тегів, що містять інформацію про номери синтаксично залежних слів із зазначенням типу зв'язку між головним та залежним словом. Слову, визначеному вершиною ДЗ, приписується мітка ядерного слова структури.

ACA $є$ одним 3 етапів машинного перекладу - морфологічно розмічене речення надходить на синтаксичний аналізатор, в якому відбувається синтаксичне маркування, з результатами якого далі працює програма-перекладач.

Завданням синтаксичного аналізатора ЛК є побудова синтаксичного дерева речення, при цьому форма представлення результатів має бути придатною для автоматичного маркування корпусу на вищих рівнях - міжфразових єдностей та семантичному - та проведення синтаксичних досліджень.

Диференційними ознаками, на яких будується алгоритм синтаксичного маркування, є:

1. Мітки початку і кінця речення.

2. Мітки, що позначають вставлені тексти інших авторів - пряму мову, цитати (проставляються при структурному маркуванні).

3. Морфологічні двосимвольні коди, поставлені у відповідність кожній текстовій словоформі, що містять інформацію про актуалізацію текстовими словами конкретних граматичних значень (лексико-граматичні класи і грамеми).

4. Мітки, поставлені у відповідність сполукам графічних слів, визнаних у певних текстових ситуаціях еквівалентами лексичного слова (складені прийменники, прислівникові сполучення, складні сполучники). Контактні сполуки слів, визначені як текстові еквіваленти слова, можуть формально одержувати при синтаксичному маркуванні одне з двох представлень: 1) як два 
слова, між якими існує другорядний (квазі)синтагматичний зв’язок підпорядкування (у такому разі головною вершиною умовно приймається перше слово; від нього рисується стрілка до наступного компонента еквівалента слова); 2) як сполучення слів (компоненти еквівалента слова відокремлюються нижнім підкреслюванням без пробілу, стрілка залежності рисується від останнього компонента, якому й приписується морфологічний код. Зрозуміло, що таке представлення вимагає перенумерування слів у реченні).

Приклади:

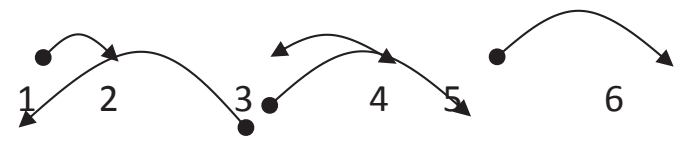

До нього звернулися друзі за $<$ ро $>$ допомогою $<$ fo $>$.

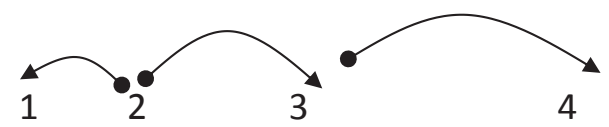

Це зроблено за допомогою $<\mathrm{pt}>$ автомата.

Типи синтаксичних зв'язків, що розпізнаються при синтаксичному маркуванні:

1. Зовнішні синтаксичні зв'язки, що встановлюються між предикативними частинами (ПЧ) складного речення. До них належать:

(1.1) безсполучниковий зв'язок (Б3) - встановлюється між предикативними центрами (ПЦ) в напрямку від першого до другого, від другого до третього і т.ін.;

(1.2) сурядний сполучниковий зв'язок (CC) - встановлюється між предикативними центрами (ПЦ) через сполучник сурядності;

(1.3) сполучниковий підрядний зв'язок (СП) - встановлюється між предикативними центрами (ПЦ) а) через сполучник підрядності; б) через співвідносне слово головного речення і сполучник підрядності в залежному реченні; (в) у випадку співвідносних сполучників в головному і залежному реченнях (якщо , то.....) - через сполучник речення і сполучник у залежному реченні.

У дереві залежностей кожна частина складного речення утворює окреме піддерево з незалежною вершиною.

2. Внутрішні синтаксичні зв'язки, що встановлюються в межах простого речення або предикативної частини складного речення. До них належать:

(2.1) зв'язок координування між компонентами предикативного ядра (KR );

(2.2) зв'язок керування (PR);

(2.2) зв'язок узгодження (AR);

(2.2) зв'язок прилягання між дієслівними формами і прислівником (HR);

(2.2) зв'язок сурядний (SR).

3. Другорядні (квазі)зв'язки, що встановлюються між компонентами складного присудка (pr) та складного підмета (sr). 
Першим етапом синтаксичного маркування $\epsilon$ сегментація речення за розділовими знаками та сполучниками. До завдань цього етапу належить ідентифікація в реченні вставних слів (конструкцій), відокремлених зворотів та визначення кількості предикативних центрів. У складному реченні, в якому за визначенням, кількість ПЦ $\geq 2$, проставляються мітки початку (П) і кінця (К) предикативної частини. Ієрархія ПЧ визначається за числовими індексами, які приписуються цим міткам - початок і кінець однієї ПЧ маркуються мітками 3 однаковими індексами.

Приклад розмітки першого етапу семантичного маркування:

$<\mathrm{b}>$ висновок $<$ п1 > про існування одиниць, для $<$ п $2>$ яких мова дозволяє функціонування тільки у змішаних семантичних станах $<$ к2> може бути досить цікавим свідченням неможливості повної формалізації мовної системи <к1>. <е >

Об’єктом наступних етапів синтаксичного маркування $є$ окрема предикативна частина, до неї прирівнюється й просте речення. Кожному з етапів в алгоритмі відповідає окремий модуль ідентифікації певних типів синтаксичних зв'язків, починаючи зі встановлення предикативного центру (зв'язок координації), дієслівних (керування, прилягання), прийменникового і безприйменникового, іменних безприйменникових (керування, узгодження), зв'язку залежності відокремлених зворотів. Модульний принцип побудови системи АСА уможливлює поетапне фрагментарне синтаксичне маркування корпусу в міру того, як проходять апробацію певні алгоритми системи. Результати кожного такого етапу маркування вже можуть бути використані при розв'язанні певного кола лінгвістичних проблем, що буде продемонстровано нижче.

Результати синтаксичного маркування тексту представляються у вигляді ЛБД, в якій кожному реченню ставиться у відповідність його «древесна» структура в табличній формі, що містить інформацію про зовнішні синтаксичні зв’язки між предикативними частинами складного речення, зв’язки кожного слова у межах предикативної частини, а також про функцію розділових знаків. У таблиці за кожним видом інформації закріплено певне поле, що забезпечує, по-перше, легкий перехід від табличного представлення дерева залежностей до графічного, i, по-друге, уможливлює формування інформаційних запитів не тільки щодо кожного окремого параметру, заданого у полях таблиці, але й щодо певної комбінації цих параметрів.

В табл. 19.7 наводиться фрагмент ЛБД із записом в ній двох речень:

Введено поняття змішаного семантичного стану. Це стосується питань багатомовного словникарства, які набули останнім часом набули нових вимірів популярності.

Інформаційні поля ЛБД:

Поле 0 - текстове слово (TC); Поле 1 - морфологічний код $T C$;

Поле 2 - номер речення в тексті; Поле 3 - номер слова в реченні;

Поля 4, 5 - структурне маркування речення - початок (4), кінець (5);

Поля 6, 7 - зовнішні зв'язки (умовний «хазяїн» ПЧ - предикат головного речення, умовний «слуга» в залежній ПЧ). 
Поля 8, 9, 10 - внутрішні зв'язки: 8 - для визначення вершини дерева залежностей; 9 - для номера слова - синтаксичного «хазяїна» і тип зв'язку; 10 для номера слова - синтаксичного «слуги» і тип зв'язку;

Поле 11 - функції розділових знаків;

Поля 12, 13, 14, 15, 16, 17 - допоміжні зв'язки: 12 - для номера слова синтаксичного «хазяїна» в складному присудку, 13 - для номера слова синтаксичного «слуги» в складному присудку, 14 - для номера слова синтаксичного «хазяїна» в складному підметі, 15 - для номера слова синтаксичного «слуги» в складному підметі; 16, 17 - фіксують зв'язок відокремленого звороту. 
宜

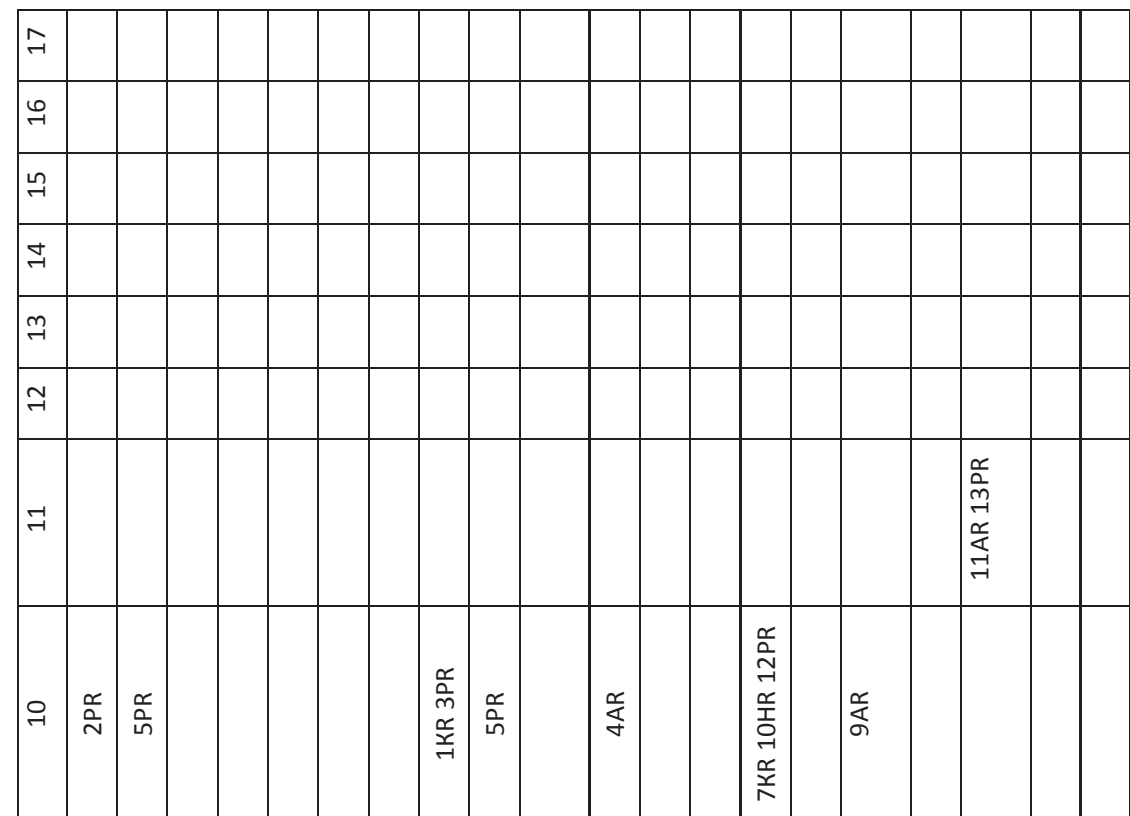

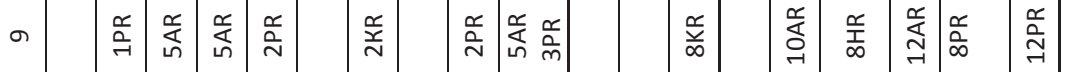

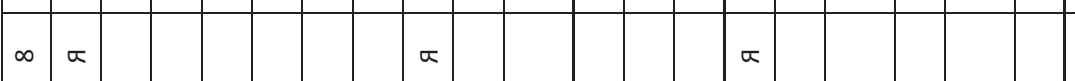

\begin{tabular}{|c|c|c|c|c|c|c|c|c|c|c|c|c|c|c|c|c|c|c|c|c|}
\hline & & & & & & & & & & & & & & & & & & & & \\
\hline$\wedge$ & & & & & & & & & & & & & 듬 & & & & & & & \\
\hline 0 & & & & & & & & & $\stackrel{m}{c}$ & & & & & & & & & & & \\
\hline in & & & & & & 孚 & & & & & 爻 & & & & & & & & & $\stackrel{2}{N}$ \\
\hline ナ & 드 & & & & & & 득 & & & & & & ${ }_{n}$ & & & & & & & \\
\hline . & $-r$ & $N$ & $m$ & $\sigma$ & in & 6 & -1 & $\sim$ & $m$ & 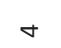 & in & 0 & $r$ & $\infty$ & $a$ & 오 & $\exists$ & ㄱ & $\stackrel{m}{r}$ & I \\
\hline
\end{tabular}

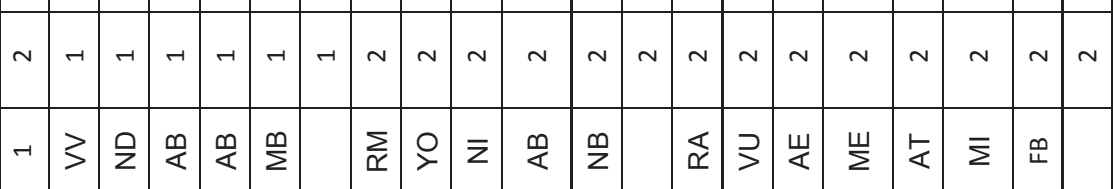

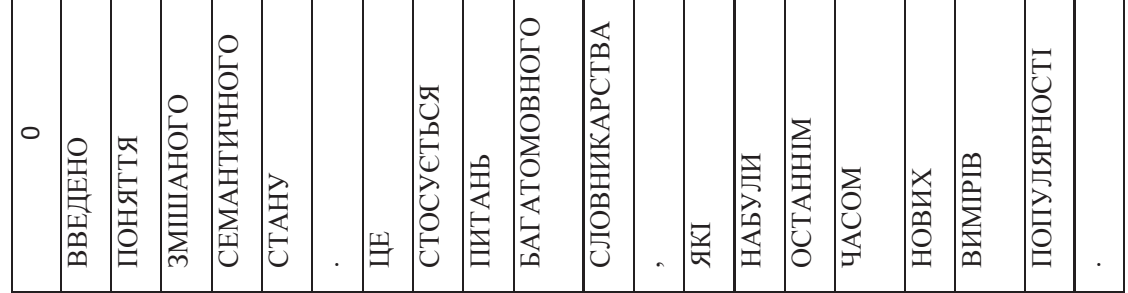


Наведемо для прикладу кілька лінгвістичних завдань, які можуть розв'язуватися на масиві синтаксично маркованих текстів, представленому у відповідній ЛБД.

Визначення середньої довжини простого речення в українській мові. За даними полів 2 (номер слова в реченні) i 3 (кінець предикативної частини) можливо підрахувати для кожної зафіксованої довжини речення (номер слова 3 міткою «К» мінус кількість розділових знаків) кількість відповідних їй речень. Середня довжина обчислюється як частка від ділення суми добутків довжини речення на кількість речень 3 певною довжиною на загальну кількість речень.

Формування субкорпусів речень заданої довжини. За даними полів 2 і 3 можна формувати субкорпуси речень будь-якої заданої довжини.

Формування субкорпусів особових та безособових речень. Субкорпус особових речень формується 3 тих, в яких мітка «Я» в полі 9 стоїть лише в одного слова. За кон'юнкцією полів 8 і 9 можна сформувати субкорпус безособових речень - до нього автоматично відберуться речення, в яких у слова з заповненим полем 8, поле 9 порожнє.

Формування субкорпусів речень певної синтаксичної будови. Серед складних речень, тобто таких, у яких заповнені поля зовнішніх зв'язків, залежно від знаходження в цих полях синтаксичних кодів Б3 можна формувати субкорпуси безсполучникових складних речень, складнопідрядних речень, речень з сурядним зв'язком.

Формування субкорпусів речень з різними типами зв'язку між головною та підрядними частинами. Серед складнопідрядних 3 кількома підрядними реченнями (у таких в полі 4 буде більше двох міток кінця) за послідовністю міток початку і кінця речення можна формувати речення з різними типами зазначеного зв'язку.

Формування файлів різних синтаксичних конструкиій. За інформацією полів внутрішніх зв'язків, вилученою з синтаксичних кодів про тип зв'язку, можна формувати файли різних синтаксичних конструкцій.

Дослідницький потенціал синтаксично маркованого тексту колосальний. Але й ці кілька наведених вище завдань, на нашу думку, переконливо доводять, що чим вищий ступінь лінгвістичного маркування ЛК, тим більший об'єм роботи з матеріалом можна виконувати за допомогою комп'ютера і тим більш надійними постають результати досліджень.

\subsection{4. Семантичне маркування УНЛК}

Як вже зазначалось, семантичне маркування лінгвістичних корпусів набуває особливого значення для сучасного дослідження мови i створення високоефективних комп'ютерних засобів іiі опрацювання, оскільки дозволяє проводити фронтальні семантичні дослідження на репрезентативних масивах 
мови, а не тільки на окремих прикладах, як це традиційно відбувалось у «докорпусній» лінгвістиці. Зокрема, семантично маркований корпус надає інструмент для перевірки гіпотез стосовно семантичних неоднозначностей та верифікації алгоритмів їхнього зняття, що відкриває безмежні можливості для створення та впровадження ефективних технологій комп'ютерного опрацювання знань.

У найпростішій постановці семантичне маркування полягає в приписуванні кожній текстовій словоформі $x$ iï лексичного значення - семантичного стану $c_{M}(x) \in C(x)$ у будь-якому контексті $M(x)$ текстового масиву ЛК. Як зазначалося, автоматичних засобів семантичного маркування поки що не створено, хоча роботи у цьому напрямі ведуться. Розроблення відповідного інструментарію передбачає проведення грунтовних досліджень саме на семантично маркованих текстах із метою визначення й типізації семантичних ситуацій, на основі чого вже можуть бути здійснені певні узагальнення та проведена формалізація, що уможливить автоматичні або бодай автоматизовані процедури семантичного маркування довільного природномовного тексту.

Джерелом семантичних станів лексичного рівня $c_{M}(x) \in C(x)$ (точніше текстовими репрезентантами семантичних станів) зазвичай слугують словникові дефініції тлумачних словників. У Фонді розроблено глибоко структуровану лексикографічну БД тлумачного Словника української мови, де експліковано семантичні стани лексичного рівня. Розроблено також системотехніку інтегрування УНЛК з ЛБД СУМ, що дозволяє виконувати семантичне маркування УНЛК в інтерактивному режимі.

Семантичне маркування відкриває перспективи для розроблення певної стратегії опрацювання тексту, яка має за мету його розуміння. Тут не йдеться про розроблення процедур діалогу з метою уточнення або «підтримки розмови» (на цьому етапі не здійснюється моделювання процесів активної реакції системи розуміння), а лише про використання в режимі семантичного аналізатора. Зазначений аналізатор повинен будуватися у такий спосіб, щоб його робота не базувалася на стаціонарній резидентній підсистемі мовної компетенції розробника або користувача, а була би цілком автономною. Ця вимога зумовлює таку етапність стратегії опрацювання природномовного тексту:

1. Прочитування тексту й формування його конкордансу (з використанням алгоритмів граматичної ідентифікації, лематизації і парадигматизації).

2. Побудова словника аналізованого тексту у вигляді підсловника СУМа 3 реєстром відповідно до одержаного конкордансу.

3. Побудова синонімічних рядів (синсетів) та інтегрованої ЛБД тлумачного та синонімічного словників (UkrWordNet).

4. Визначення множини семантичних станів лексичних одиниць тексту.

5. Побудова «пристрілочної» функції належності (перше наближення).

6. Побудова узагальнених синтаксичних структур вихідного тексту. 
7. Ідентифікація структур керування та узгодження у вихідному тексті.

8. Ідентифікація фразеологізмів та інших колокацій у вихідному тексті.

9. Знаходження відповідників структур п. 8, п. 9 в інтегрованій системі СУМ + ССУМ.

10. Побудова розширеної системи СУМ + ССУМ у разі незнаходження деяких відповідників структур п. 8, п. 9.

11. Побудова функції належності в другому наближенні.

12. Ідентифікація понадфразових єдностей у тексті.

13. Уточнення семантичних станів лексичних одиниць 3 урахуванням понадфразових єдностей.

14. Побудова другого розширення системи СУМ + ССУМ 3 урахуванням понадфразових єдностей.

15. Побудова функції належності в третьому наближенні.

16. Інтерпретація вихідного тексту.

Застосування розвиненого у Фонді апарату уможливлює зведення майже всіх зазначених етапів до автоматичних або автоматизованих процедур. Підлягають повній або часткові автоматизації й операції з даними, спрямовані на модифікацію та розширення вихідної лексикографічної системи (у т. ч. лінгвістичного корпусу) А саме: введення вхідного текстового слова; граматична ідентифікація вхідного текстового слова; лематизація вхідного текстового слова; парадигматизація вхідного текстового слова; побудова шаблона $\Lambda(x)$ вхідного текстового слова; побудова шаблона $P(X)$ вхідного текстового слова; знаходження аналога в СУМі і побудова гіпотези для елементів $\Lambda(x)$; знаходження аналога в СУМі і побудова гіпотези для елементів $P(X)$; заповнення шаблона $\Lambda(x)$ відповідно до гіпотези; заповнення шаблона $P(X)$ відповідно до гіпотези; лексикографічне редагування словникової статті; занесення словникової статті до лексикографічної системи.

Описані процедури за умови доопрацювання та уточнення в принципі дозволяють «запустити» процес саморозвитку лексикографічної системи. Це означає, що поєднання текстового аналізатора 3 лексикографічною системою дозволить створювати динамічні словники, здатні до самонавчання, тим самим збільшуючи інтелектуальні можливості початкової системи.

Інший варіант словникової динаміки реалізується через динаміку ваг $\mu$, які входять у визначення повного семантичного стану лексеми. У комп'ютерному семантичному словнику елементарні і повні семантичні стани представлені в експліцитній формі і є елементами відповідної лексикографічної структури. Система ваг $\mu$ для кожної лексеми початково вводиться до словника декларативно - через експертні висновки лексикографів-укладачів. Із визначення ваг $\mu$ зрозуміло, що вони здебільшого мають статистичний характер, отже алгоритм знаходження їхніх конкретних значень у найпростішому варіанті може пов'язуватися з частотами зустрічності відповідних елементарних станів при 
опрацюванні текстів. Реалізація такого алгоритму вводить ще один тип динаміки до семантичного словника, а саме: динаміку семантичних станів, на основі якої можливе налаштування семантичного аналізатора на аналіз текстів 3 проблемноорієнтованою семантикою. Зазначені лексикографічні системи, образно кажучи, «перебирають» на себе інтелект тих текстів, що проходять крізь них у процесі семантичного аналізу. Останнє ще раз підкреслює спорідненість лексикографічних систем із системами штучного інтелекту.

Лексикографічні структури мають основне навантаження також у технологічній схемі розроблення лексикографічних систем, оскільки формалізм структурного моделювання лексикографічних систем спроможний повністю відтворити деталі представлення будь-яких словникових текстів (навіть таких складних, як текст СУМа або великих дво- та багатомовних словників). Це надає широкі можливості його застосування для розроблення технології укладання словників різних типів. При цьому піддаються суцільній автоматизації такі функції, як: генерація узагальненої абетки словника; породження структури словникових статей конкретного словника i формування відповідної БД; граматична ідентифікація об'єктів словника (включаючи лематизацію та автоматичну побудову парадигми для повнозначних відмінюваних частин мови); злиття словників та одержання підсловників вихідного словника; виконання коректорських і редакторських робіт; формування оригінал-макету готового словника.

Перевагою автоматизованої технології укладання словників є одержання, крім традиційного словникового тексту, також і нових видів лексикографічної продукції у вигляді комп’ютерних лексикографічних систем.

Отже, для забезпечення семантичного маркування ЛК в інтерактивному режимі необхідно мати відповідний комп'ютерний інструментарій, який передбачає інтеграцію до ЛК структурованого у певний спосіб тексту комп’ютерного тлумачного словника, що підлягає маркуванню. Такий інструмент створюється у Фонді на базі інструментального комплексу ВЛЛ_СУМ, на якому здійснюється укладання 20-томного Словника української мови. В цифровому варіанті цього словника експліковано велику кількість семантичних елементів: лексичні значення слів, відтінки значень, подано репертуар колокацій (фразеологізми, ідіоми, еквіваленти слів, терміносполучення) з їхніми значеннями та відтінками значень, а також текстові ілюстрації до всіх семантичних елементів. Зазначену систему реалізовано на масиві понад 200 тис. лексичних одиниць; разом із дериватами та варіантами система охоплює ще й понад 50 тис. колокацій. Інтегрування БД тлумачного Словника української мови до УНЛК надає користувачеві інструмент лексичного маркування текстів на семантичному та фразеологічному рівнях. Інший спосіб семантичного маркування може бути реалізований шляхом інтегрування до УНЛК синонімічної підсистеми або української версії семантичного словника WordNet. 
Організована в окреслений спосіб система семантичного маркування УНЛК надає апарат до «обчислення» семантичних станів слів у їхніх контекстуальних локалізаціях у корпусі, а також до проведення різноманітних семантичних та когнітивних досліджень на семантично маркованому корпусі.

В УНЛК як у системі, що розвивається, передбачається також створення інших інструментів маркування для одиниць та відношень різних рівнів мови, наприклад, синтаксичних, етимологічних, родо-видових та ін. відношень, фонетичного транскрибування тощо.

Розмічені на різних рівнях мови ЛК та супровідні програмні засоби дозволяють ввести в лінгвістичні дослідження прийоми і методи контекстуальної діагностики і тим самим сприяти розв'язанню таких актуальних завдань, як створення нових електронних словників або модернізація (актуалізація) існуючих в осяжні терміни, здійснення автоматичного перекладу на нових засадах 3 наданням пріоритету перекладним словникам словосполучень, що визначаються за паралельними корпусами текстів мов - учасниць перекладу, підвищення ефективності систем машинного перекладу шляхом використання міжмовних текстових конкордансів, побудованих за паралельними корпусами для конкретних значень багатозначних слів при виборі відповідних їм перекладних еквівалентів. Прискоренню та підвищенню якості перекладу сприяє звернення до комп'ютерної «пам'яті перекладів» - БД, системотехніку якої розроблено саме методами корпусної лінгвістики, що відкрило шляхи до розв'язання тих проблем, які, на думку більшості мовознавців, носять найбільш суб'єктивний характер і стосуються розмежування багатозначних слів і омонімів, визначення значень i відтінків значення багатозначного слова та встановлення їхньої ієрархії в статтях тлумачного словника, відстеження змін у позиції «основне - другорядне значення», зумовлених змінами в суспільній реальності та ін. Об'єктивізувати роботу лексикографа в цьому напрямку можливо шляхом поєднання контекстного та статистичного аналізів, що, будучи застосованим до репрезентативного корпусу текстів, забезпечить виконання відомих постулатів Л. Щерби щодо реалізації мовною одиницею свого значення лише в контексті 3 іншими одиницями («слово саме по собі нічого не значить...») і щодо необхідності проведення лінгвістичних досліджень на «організованому певним чином мовному матеріалі з урахуванням кількісних показників». 3 позиції корпусної лінгвістики другий постулат може бути інтерпретовано, по-перше, як представлення в цифровому вигляді колекції повнотекстових джерел достатнього обсягу для статистичних оцінок аналізованих мовних фактів, i, по-друге, структурування цього матеріалу має здійснюватися в спосіб, що забезпечує дослідникові релевантні відповіді на запити будь-якого характеру в масиві окреслених ним хронологічними рамками текстів.

Можливості, які відкриває ЛК перед лексикографами, наприклад, для простежування динаміки зміни позицій основного і другорядного значень слова, 
значення і відтінків, яке доцільно було б робити при перевиданні класичних тлумачних словників, можна проілюструвати на слові «книга». У словнику Бориса Грінченка (1907 р.) знаходимо: «Книга - 1) книга (Листоньки пише, книги читає) 2) том, часть сочіненій... У тлумачному Словнику української мови в 11 томах, що укладався на матеріалах лексичної картотеки Інституту мовознавства ім. О. О. Потебні: «Книга - 1) велика обсягом або важлива за змістом книжка (у знач. 1), і як відтінок значення: «Книжка - 1) зброшурована в одне ціле й оправлена певна кількість (звичайно понад 5) друкованих або рукописних аркушів...». Ці самі тлумачення знаходимо й у Великому тлумачному словнику сучасної української мови під ред. В. Т. Бусела $(2001 ; 2005)$ та в новій версії СУМ-20. Аналіз конкордансів слів «книга» й «книжка», одержаних за лічені секунди $з$ текстів різних стилів, що входять до УНЛК, переконали нас в тому, що атрибути «великий обсяг» i «важливість змісту» не є релевантними для прямого значення слова «книга». Їх можна визнати характерними для переносного значення «джерело знань» у контекстах «книга життя», «Велика Книга» тощо.

\subsubsection{1. Формальні аспекти відношення синонімії та аналогія з визначенням перекладних еквівалентів}

Дослідженню явища синонімії присвячено багато праць, проте формальні засади його опису, на нашу думку, розроблені ще недостатньо. Вважатимемо, що лексеми $x$ та $y$ перебувають у відношенні синоніміі $S$ (цей факт позначатимемо записом: $x S y$ ), якщо існують семантичні стани $c(x)$ та $c(y)$, що відповідають певним лексичним значенням розглядуваних лексем, які є близькими для всіх граматичних значень цих лексем: $|c(x) \approx c(y)|$. Це означає, що:

$$
|c(x)-c(y)|>\varepsilon
$$

$\varepsilon-$ певна достатньо мала величина.

Зрозуміло, що для оцінки величини $|c(x)-c(y)|$ необхідно мати такі формальні визначення $c(x)$ та $c(y)$, які дозволяють обчислити різницю $c(x)-c(y)$ та оцінити іiі величину. Це є досить складним завданням, i на практиці виконується дещо зовсім інше, а саме здійснюється експертна оцінка лінгвістом, який, аналізуючи значення (семантичні стани) $c(x)$ та $c(y)$ i покладаючись на свій досвід та інтуїцію, сам встановлює їхню близькість, використовуючи, зазвичай, не дуже чіткі критерії.

Відзначимо деякі формальні властивості відношення синонімії. Очевидно, що воно $є$ рефлексивним і транзитивним, тобто $x S y$ та $x S y \Rightarrow y S x$. Утім, відношення синонімії необов'язково транзитивне, тобто з фактів $x S y$ та $y S z$, не випливає $x S z$. Це означає, що різниці $|c(x)-c(y)|$ та $|c(y)-c(z)|$ можуть накопичуватися так, що врешті-решт виявиться, що $|c(x)-c(z)|<\varepsilon$. Утім, ми розглядатимемо тільки такі синонімічні ряди (синсети) $S X$, що якщо $X=$ 
$\left\{x_{1}, x_{2}, \ldots, x_{n}\right\}$ - множина лексем, які становлять певний синсет $S X$, то $x_{i} S x_{j}$ для всіх $i, j=1,2, \ldots, n$.

Це надає можливість позначити множину значень синсета $S X$ через C $(S X)$. Отже, для будь-яких $c(x) \in \mathrm{C}(S X)$ та $c(y) \in \mathrm{C}(S X),|c(x)-c(y)|<\varepsilon$.

Відзначимо принципову різницю між описом лексичної семантики у тлумачних словниках та описом синонімії. А саме, тлумачний словник прагне подати, так би мовити, абсолютну семантику, тобто для кожної лексеми $x$ визначити й описати якомога повніше множину її семантичних станів:

$$
C(x)=\left\{c_{i}(x) \mid \mathrm{i}=1,2, \ldots, \mathrm{k}\right\},
$$

причому так, що для будь-якого контексту $M(x)$ знайшовся $\sigma$ елемент $c_{M}(x) \in \mathrm{C}(x)$, який представляє значення лексеми $x$ у цьому контексті. Зрозуміло, що множина $C(x)$ містить як чисті, так і змішані семантичні стани.

Натомість семантика синонімії $є$ відносною i в формалізмі семантичних станів представлена лише різницею $|c(x)-c(y)|$ семантичних станів $c(x)$ та $c(y)$, для яких, як зазначалося, висувається вимога близькості. Залишається 3'ясувати, в який спосіб можна встановити близькість семантичних станів $c(x)$ та $c(y)$, і отже, «обчислити» різниці $|c(x)-c(y)|$. Одним з можливих способів до цього $є$ певне структурування словникових дефініцій (формул тлумачення), за допомогою якого можливе більш формальне поводження 3 елементами семантичної структури. Для демонстрації викладеного скористаємося апаратом, викладеним у другій книзі третього тому цього видання, де пропонується метод розвинення словникових дефініцій дієслова у лінійний формат такого вигляду:

\begin{tabular}{|c|c|c|c|c|c|c|c|c|c|c|}
\hline \multicolumn{11}{|c|}{ Формат дефініцій дієслова } \\
\hline \multirow[b]{2}{*}{$\begin{array}{c}\text { Семантична } \\
\text { тема }\end{array}$} & \multicolumn{10}{|c|}{ Диференційні семи } \\
\hline & 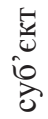 & $\begin{array}{l}5 \\
0 \\
0 \\
0\end{array}$ & 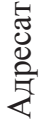 & 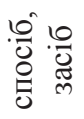 & 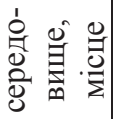 & $\underset{\widetilde{J}}{\mathbb{\sigma}}$ & $\sum^{\frac{\pi}{2}}$ & $\begin{array}{l}\stackrel{\pi}{0} \\
\sum^{0} \\
\Sigma\end{array}$ & 壱 & $\begin{array}{c}\text { ступінь, } \\
\text { інтенсивність }\end{array}$ \\
\hline 1 & 2 & 3 & 4 & 5 & 6 & 7 & 8 & 9 & 10 & 11 \\
\hline
\end{tabular}

Використовуючи цей формат, будь-яку дієслівну словникову дефініцію (принаймні, з тлумачного Словника української мови) можна розкласти в лінійну послідовність компонент (1-11). Приклади такої декомпозиції наведено нижче в таблиці.

\begin{tabular}{|c|c|c|c|c|}
\hline \multicolumn{5}{|c|}{ Формат дефініцій дієслова } \\
\hline \multirow[t]{3}{*}{ Реєстрова одиниця } & \multirow[t]{3}{*}{ Семантичний стан } & \multirow[t]{2}{*}{ Семантична тема } & \multicolumn{2}{|c|}{ Диференційні семи } \\
\hline & & & об’єкт & $\begin{array}{c}\text { спосіб, } \\
\text { засіб }\end{array}$ \\
\hline & & 1 & 3 & 5 \\
\hline \multirow[t]{2}{*}{$\begin{array}{l}\text { ГОВОРÚТИ, ворю, } \\
\text { во́риш, недок. }\end{array}$} & \multirow{2}{*}{$\begin{array}{l}1 \text { Мати здатність } \\
\text { висловлю-вати думки, } \\
\text { почуття; воло-діти } \\
\text { мовою. }\end{array}$} & $\begin{array}{c}\text { Мати здатність } \\
\text { висловлювати }\end{array}$ & $\begin{array}{l}\text { думки, } \\
\text { почуття }\end{array}$ & - \\
\hline & & Володіти & - & мовою \\
\hline
\end{tabular}




\begin{tabular}{|l|l|l|l|l|}
\hline $\begin{array}{l}\text { РОЗМОВЛХТИ, яю, } \\
\text { яєш, недок. }\end{array}$ & $\begin{array}{l}\text { 2. Мати здатність, уміти } \\
\text { говорити, висловлювати } \\
\text { свої думки, почуття. }\end{array}$ & $\begin{array}{l}\text { Мати здатність, } \\
\text { уміти говорити, } \\
\text { висловлювати }\end{array}$ & $\begin{array}{l}\text { воої думки, } \\
\text { почуття }\end{array}$ & - \\
\hline $\begin{array}{l}\text { 3. Говорити, володіти } \\
\text { якою-небудь мовою. }\end{array}$ & Говорити, володіти & - & $\begin{array}{l}\text { якою- } \\
\text { небудь } \\
\text { мовою }\end{array}$ \\
\hline $\begin{array}{l}\text { БАЛАКАТИ, аю, } \\
\text { аєш, недок. }\end{array}$ & $\begin{array}{l}\text { 1. про кого, ще } i \text { без дод. } \\
\text { Те саме, що розмовляти }\end{array}$ & Розмовляти & - & - \\
\cline { 2 - 5 } & 2.розм. Володіти мовою. & Володіти & - & мовою \\
\hline
\end{tabular}

Порівняння семантичних станів за допомогою наведеного лінійного формату зводиться до порівняння відповідних його компонент. Наприклад, для дієслова «говорити» таке порівняння визначає два семантичних стани: $\mathrm{C}_{1}(\mathrm{x})=$ Мати здатність, уміти говорити, висловлювати свої думки, почуття; $\mathrm{C}_{2}(\mathrm{x})=$ Володіти якою-небудь мовою, яким відповідає один синсет: \{розмовля́ти; говори́ти; бала́кати\}.

Зазвичай, на практиці семантика тлумачних словників, на жаль, не відповідає семантиці словників синонімічних, тобто визначення семантичних станів при синонімії, що описано формулою (19.1), не завжди узгоджуються 3 визначеннями станів лексичної семантики, представленими формулою (19.2). Це спричиняє значні проблеми при створенні семантичних аналізаторів, перекладних словників і систем лексикографічного забезпечення машинного перекладу.

Відзначимо, однак, що між установленням синонімії та знаходженням перекладних еквівалентів існує глибока аналогія. Вона грунтується на тій обставині, що якщо знаходження синоніма зводиться до пошуку близьких значень лексем однієї мови, то знаходження перекладного еквівалента є таким самим пошуком близьких значень, але для різних мов. Введемо верхній індекс біля мовної одиниці та її семантичного стану для позначення мови, в якій цю одиницю (або стан) представлено. Тоді синонімія зображатиметься співвідношенням:

$\left|c^{i}(x)-c^{i}(y)\right|<\varepsilon$, де $i-$ індекс, що маркує мову.

Натомість відношення «перекладний еквівалент»: $x^{1} \mathrm{~T}^{2}$, де $x^{1}, x^{2}, \epsilon$ представленням лексеми $x$ у мовах 1 i 2 , відповідно, зображатиметься співвідношенням $\left|c^{1}\left(x^{1}\right)-c^{2}\left(x^{2}\right)\right|<\varepsilon$. Зрозуміло, що для формального визначення цієї процедури необхідно звести величини $c^{1}\left(x^{1}\right)$ та $c^{2}\left(x^{2}\right)$ до якогось єдиного представлення, яке може надавати, наприклад, мова-посередник позначатимемо ii верхнім індексом 0. Отже, спочатку маємо відображення $c^{1}\left(x^{1}\right) \rightarrow c^{0}(x)$ та $c^{2}\left(x^{2}\right) \rightarrow c^{0}(y)$. Тоді одержуємо еквівалентність:

$$
\mathrm{xSy} \Leftarrow|c(x)-c(y)|<\varepsilon \sim\left|c^{1}\left(x^{1}\right)-c^{2}\left(x^{2}\right)\right|<\varepsilon \Rightarrow x^{1} T x^{2} .
$$

3 формули (19.3) випливає, що пошук перекладного еквівалента $з$ однієї мови на іншу рівнозначний знаходженню синоніма в абстрактній мовіпосереднику. Незважаючи на те, що така мова наразі залишається невідомою величиною концептуального моделювання (зокрема неочевидною постає універсальність такої мови), формула (19.3) надає ключ до розуміння ролі 
синонімії в процесі перекладу з однієї мови на іншу: конструювання величин $c^{0}(x)$ і $c^{0}(y)$ передбачає наявність множин $C^{1}\left(S X^{1}\right)$ та $C^{2}\left(S X^{2}\right)$ й встановлення між ними певної відповідності - навіть за відсутності формального методу ії визначення.

\section{7. Системотехнічні та технологічні засади побудови УНЛК}

Метою цього підрозділу $є$ викладення основних системотехнічних та технологічних засад побудови УНЛК. Автори свідомі, що далеко не всі мовознавці зараз готові самостійно опанувати необхідний програмно-системний інструментарій та будувати на його базі власні лінгвістичні корпуси, тому інформація, викладена в цьому підрозділі, орієнтована, перш за все, на фахівців 3 інформаційних технологій. При цьому слід зауважити, що програмне забезпечення постійно вдосконалюється і вже при виданні цієї книги у Фонді застосовується дещо інший, більш розвинений варіант програмного комплексу УНЛК. Проте, очевидно, що він $є$ i більш складним i ще не до кінця відпрацьованим у деталях, тобто, має статус експериментального, що, власне, і спонукало авторів до викладення базового варіанта.

\subsection{1. Лінгвістичний корпус як лексикографічна система}

Як зазначалось, лінгвістичні корпуси на початку своєї історії були покликані замінити традиційні лексичні картотеки, які в докомп’ютерну еру створювалися та використовувалися лінгвістами при укладанні словників та проведенні мовознавчих досліджень. Але при формуванні та використанні паперових картотек виникають труднощі, які практично неможливо подолати традиційними методами. Обсяг інформації у цих картотеках настільки великий, а пошуковий апарат нерозвинений, що ефективно використовувати паперову картотеку надзвичайно важко. Справді, пошук у картотеці можна вести тільки за заголовковими словами. При цьому контексти багатьох слів практично недосяжні через відсутність у картотеці відповідного пошукового апарату. Неможливий також пошук мікроконтекстів за параметрами граматичної семантики (не кажучи вже про лексичну), пошук за синтаксичними структурами, за параметрами бібліографічного опису літературних джерел, із яких сформовано лексичні картки та ін. Це спричиняе необхідність створення додаткових картотек та покажчиків до вже існуючих, що неймовірно важко зробити внаслідок великого обсягу інформації. Врешті-решт сама технологія формування паперової картотеки дуже непродуктивна і вимагає витрат праці, непропорційно великих порівняно з ефектом від іiі практичного використання. 
Iз розвитком комп'ютерних технологій завдання лексичних картотек вирішуються новими методами. Власне, картотека в іiі колишньому вигляді стала уже непотрібною. Адже, якщо текст або сукупність текстів занесена до пам'яті комп'ютера, а програмні засоби дозволяють прямий доступ до всіх контекстів будь-якого обраного слова, така комп’ютерно-лінгвістична система забезпечує всі функції лексичної картотеки і на додаток ще й багато інших. Комп'ютерні аналоги лексичних картотек нині створено для всіх значних світових лексикографій, причому цей процес триває як в кількісному, так і в якісному плані. Обсяги мовного матеріалу, що залучається до мовознавчого дослідження, комплексність, оперативність його опрацювання та можливість прямого доступу до великої кількості лінгвістичних фактів - це ті переваги, які надає лінгвістичний корпус досліднику. Для підтримки цих сервісів лінгвістичний корпус повинен мати відповідну будову, що забезпечує представлення, маркування та експлікацію природномовної інформації. Отже, будь-який ЛК має функції: 1) репрезентації (представлення) даних; 2) маркування (тегування, анотування; розмічання) текстів; 3) експлікації даних.

Архітектурно в ЛК виділяються дві основні підсистеми ${ }^{87}$ лінгвістична та бібліографічна.

Лінгвістична підсистема забезпечує:

- створення та редагування БД повнотекстового індексу;

- додавання об'єкта індексування;

— індексування об'єктів;

- повнотекстовий пошук слів та словосполучень у всіх документах корпусу або у відібраних за певними критеріями 3 заданою відстанню між словами пошукового запиту;

- надання статистики;

— перегляд та збереження в окремому файлі мікроконтекстів слів та словосполучень;

- сервісні функції.

Бібліографічна підсистема $є$ електронною бібліотекою - колекцією електронних ресурсів, що $\epsilon$ основою для розроблення будь-якого корпусу. Бібліографічна підсистема є інструментом збирання, збереження, моделювання й використання природномовної інформації в цифровому вигляді, тобто виконує роль багатофункціональної інформаційної системи.

Основна ідея ЛК на концептуальному рівні ${ }^{88}$ полягає в забезпеченні автоматичного розбиття електронного тексту на «мікроконтексти» - фрагменти,

${ }^{87}$ Корпусна лінгвістика: монографія / В. А. Широков, О.В.Бугаков, Т. О. Грязнухіна, О. М. Костишин, М. Ю. Кригін; НАН України, Укр. мов.-інформ. фонд. Київ: Довіра, 2005. $472 \mathrm{c}$.

${ }^{88}$ Широков В. А. Інформаційна теорія лексикографічних систем. Київ: Довіра, 1998. 330 с.; Широков В. А. Корпусна лінгвістика /В. А. Широков, О.В.Бугаков, Т. О. Грязнухіна, 
що «групуються» навколо слова - об’єкта тлумачення. При цьому підході достатньо забезпечити виконання процедури природномовної індексації тексту, що означає приписування кожній текстовій словоформі їі формально визначеної локалізації - своєрідної координати в розглядуваному тексті 3 наступною лематизацією цієї словоформи. У такий спосіб одержуємо розмічений текст, який однозначно репрезентується спеціальною Л-системою, реєстровою частиною якої є лексема у вихідній формі, а інтерпретаційною - двочленний кортеж, на першій позиції якого стоїть номер локалізації слова в тексті, а на другій - індекс граматичного значення, якого лексема набуває в цій позиції. Тоді вибором лексеми, яка цікавить, досягається послідовна демонстрація їі локалізацій у тексті, причому користувач може власноруч обирати розмір контексту.

Проте структурою Л-системи, насправді, наділений i весь ЛК, як певна мовно-інформаційна цілісність. Наведемо аргументи на користь цього твердження.

Основою ЛК згідно 3 ідеологією, прийнятою в Українському мовноінформаційному фонді, $€$ побудована відповідно до стандартних правил електронна бібліотека ${ }^{89}$. Вона складається 3 електронного каталогу та бази узагальнених об'єктів зберігання.

Представлення бібліографічного опису в сучасних електронних каталогах регламентуються такими стандартами опису бібліографічних даних: ISO-2709 ${ }^{90}$, MARC-21 ${ }^{91}$, UNIMARC ${ }^{92}$. Початковим етапом розроблення електронної бібліотеки $є$ проеєктування та реалізація концептуальної моделі БД, що здійснюєтьсявідповідно до стандарту UNIMARC та з урахуванням специфіки іï використання. Велике навантаження в розробці проєкту припадає на роботу 3 базою даних об'єкта електронної бібліотеки generalLib.

Електронна бібліотека слугує джерелом текстів для лінгвістичної підсистеми. Завдяки інтеграції цих компонентів в ЛК немає потреби зберігати мікроконтексти (аналоги колишніх лексичних карток) в окремих файлах - для будь-якого реєстрового слова словника вони є віртуальними об'єктами i генеруються автоматично за запитом.

За функціональним призначенням електронна бібліотека як підсистема ЛК покликана забезпечувати реалізацію двох основних завдань: 1) інтеграцію в єдиному середовищі інформаційних ресурсів різних типів та видів;

О. М. Костишин, М. Ю. Кригін. НАН України, Укр. мов.-інформ. фонд. Київ: Довіра. 2005. 472 c.

${ }^{89}$ Широков В. А. Інформаційна теорія лексикографічних систем. Київ: Довіра, 1998. 330 с.

${ }^{90}$ ISO 2709:1996 Information and documentation. Format for Information Exchange. URL: https://www.iso.org/standard/7675.html.

${ }^{91}$ MARC 21 Concise format for bibliographic data. Library of Congress. Network Developement and MARC Standart Office. URL: http://www.loc.gov/marc/bibliographic/ ecbdhome.html.

${ }^{92}$ UNIMARC Manual: Bibliographic Format, 1994. URL: https://www.ifla.org /publications/unimarc-formats-and-related-documentation. 
2) забезпечення можливості виокремлення масивів необхідної інформації за заданими критеріями.

Основними функціями електронної бібліотеки $є$ :

- формування короткого бібліографічного опису за правилами бібліографування на основі занесених до БД елементів метаданих об'єкта зберігання;

— формування розгорнутого бібліографічного опису об'єкта зберігання;

- редагування множини метаданих бібліографічного опису відповідно до внесених бібліографом змін;

— аналіз внесених змін до бібліографічного опису;

- робота з об'єктами файлової системи;

- редагування, додавання та вилучення профілів, характеристик, словників та їхніх елементів.

На рис. 19.9 наведено схему електронної бібліотеки $\mathbf{E}-\mathbf{L I B}$. Вона складається із двох базових підсистем: 1) B-D - блоку бібліографічних описів (електронний каталог); 2) G-O - блоку узагальнених об'єктів зберігання.

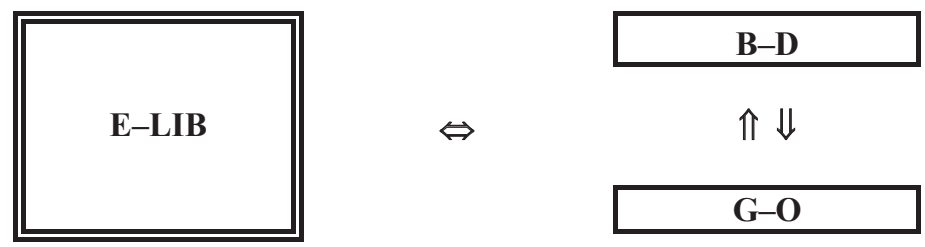

Рис. 19.8. Схема електронної бібліотеки $\mathbf{E}-\mathbf{L I B}$

Узагальненими об'єктами зберігання можуть виступати представлені в цифровій формі об'єкти у будь-яких форматах даних, що дозволяє, крім звичайних друкованих текстів, вводити до бібліотеки рукописи, аудіо-, відео- та іншу мультимедійну інформацію.

Електронний каталог підтримує стандартну систему бібліографічного опису: de facto за основу електронної бібліотеки УНЛК взято міжнародний стандарт UNIMARC. На E-LIB індукується структура Л-системи:

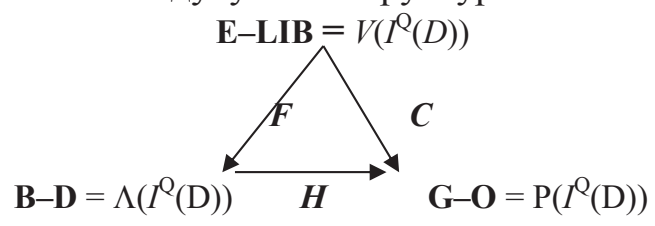

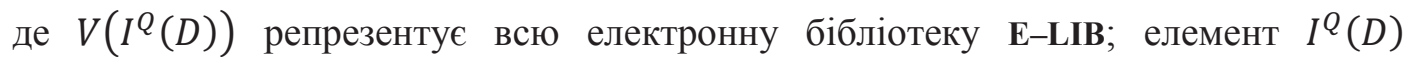
представляє множину книжок та інших об'єктів E-LIB - як завжди він подається у вигляді об'єднання окремих елементів (тут книжок) $x: x \in I^{Q}(D)$; iї формальну частину $\Lambda\left(I^{Q}(D)\right)$ представлено множиною бібліографічних описів B-D; змістову частину $P\left(I^{Q}(D)\right)$, як і належить, представляє зміст узагальнених об'єктів зберігання $\mathbf{G}-\mathbf{O}$ (у робочому варіанті ЛК ними є оцифровані тексти друкованих джерел); інтерпретація операторів $\boldsymbol{F}, \boldsymbol{C}$ та $\boldsymbol{H} \in$ звичайною, як це прийнято в теорії Л-систем. 
Подальша структура Л-системи лінгвістичного корпусу розвивається посередництвом механізму рекурсивної редукції елемента $\mathbf{G}-\mathbf{O}=P\left(I^{Q}(D)\right)$ у такий спосіб:

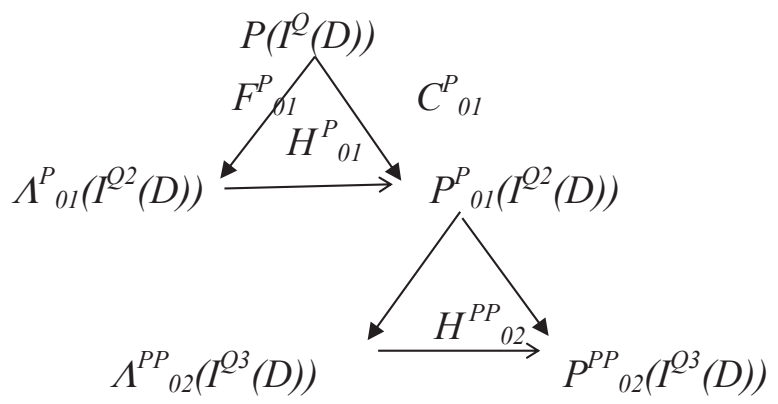

Інтерпретація елементів формули (19.5) є такою:

Другий порядок рекурсивної редукції (середній «поверх» діаграми) «відповідає» за структуру друкованого джерела, в якій виділяються вкладені об'єкти (том, частина, глава, параграф, абзац) - їх специфіковано в елементі $\Lambda_{01}^{P}\left(I^{Q 2}(D)\right)$. У структурному елементі $P_{01}^{P}\left(I^{Q 2}(D)\right)$ подаються тексти фрагментів, специфікованих елементами $\Lambda_{01}^{P P}\left(I^{Q 2}(D)\right)$.

Третій порядок рекурсивної редукції (нижній «поверх» діаграми) «відповідає» за лінгвістичну структуру тексту. Елементи $3 \Lambda_{02}^{P P}\left(I^{Q 3}(D)\right)$ підтримують формальний опис лінгвістичної системи тексту і параметризують синтаксичну структуру речень, певних словосполучень (типу фразеологізмів, ідіом, еквівалентів слова), а також систему граматичних значень на рівні лексичної системи. В елементі $P_{02}^{P P}\left(I^{Q 3}(D)\right)$ представлено текстові відповідники, параметризовані елементами з $\Lambda_{02}^{P P}\left(I^{Q 3}(D)\right)$. Отже, структура E-LIB індукується за допомогою рекурсивної редукції третього порядку.

Після проведеної системної декомпозиції схема ЛК набуває вигляду, наведеного на рис. 19.9.

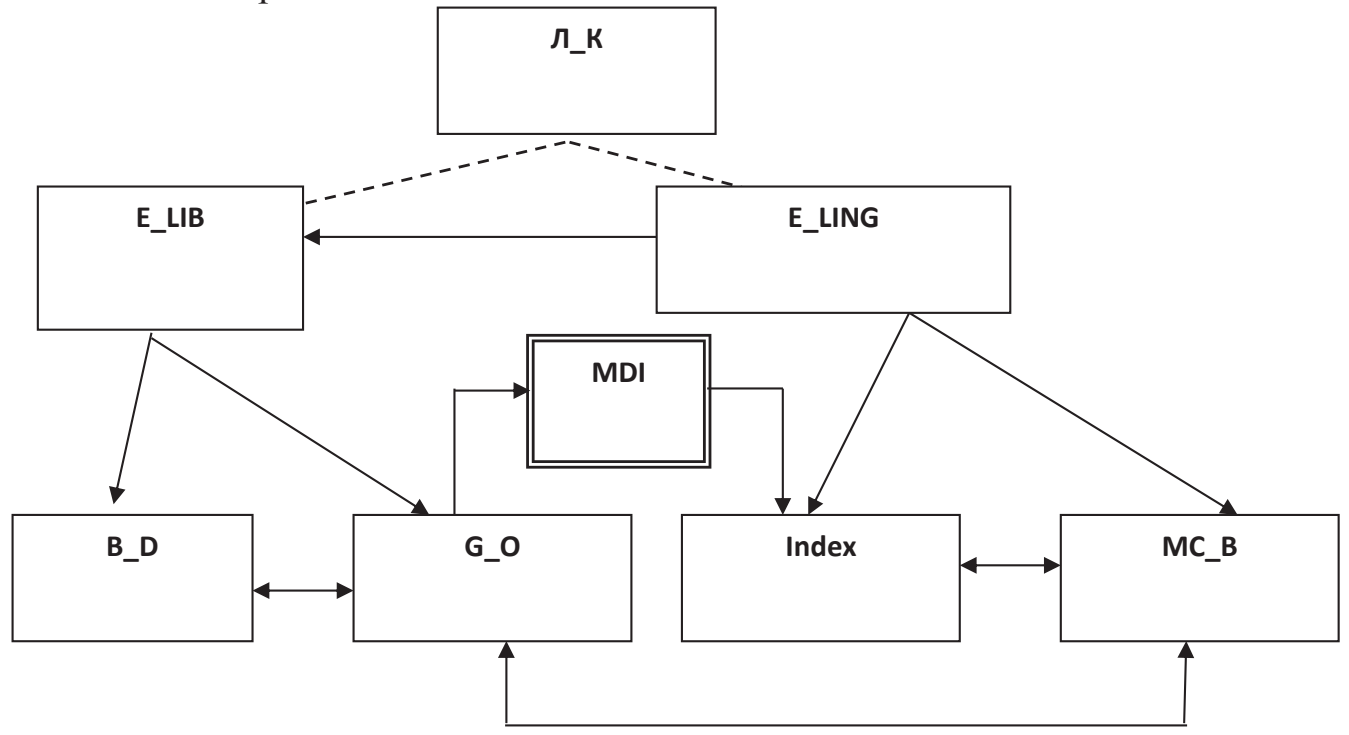

Рис. 19.9. Структурна схема УНЛК 
У цій схемі зміст використаних позначень є таким:

E_LING - лінгвістична підсистема;

MDI - підсистема побудови багатовимірного індексу; інкорпорує алгоритмічно-програмні реалізації операторів $F, C, H$;

Index - база багатовимірного індексу; представляє БД результатів роботи MDI;

MC_B - база мікроконтекстів; породжується динамічно при запиті користувача.

Викладена схема побудови УНЛК як Л-системи допускає очевидні узагальнення, а також розвиток у вимірах, специфікованих окремими елементами Л-системи.

\subsection{2 Архітектура та компоненти програмного забезпечення УНЛК}

Принципи організації програмного комплексу УНЛК, за задумом розробників, повинні надавати можливість створення вхідних потоків лінгвістичної інформації для різноманітних дослідницьких систем, а також забезпечувати інтеграцію 3 ними різнопланових програмних засобів. Iз зазначеного випливають вимоги розподіленості та багаторівневості.

У загальному розумінні розподіленою вважається система, в якій опрацювання інформації відбувається на декількох комп'ютерах. Одним зі стандартних прийомів керування складністю у розподілених системах $\epsilon$ розділення коду на частини за функціональним призначенням. Цей прийом можна використовувати на різних рівнях системи, виділяючи в більш агрегованих структурах рівня менші (наприклад, у компонентах - класи, у класах - процедури, в процедурах - коди). Програмні системи з розподіленими архітектурами, крім того, що мають значні переваги над звичайними, у багатьох випадках взагалі можуть бути здійснені тільки у такий спосіб. Фактично основні категорії розподілених архітектур різняться ступенем відповідальності, покладеної на окремі модулі, та засобами взаємодії останніх.

Найбільш ранньою та фундаментальною із розподілених архітектур є так звана архітектура «клієнт-сервер». У загальних рисах ця архітектура передбачає, що «клієнт» робить запити на обслуговування до «сервера». Клієнтський процес відповідає за рівень представлення даних. На цьому рівні виконується перевірка введених користувачем даних, запити до сервера та певні бізнес-правила. Сервер діє як механізм реалізації клієнтських запитів шляхом виконання прикладних програм та взаємодії з такими ресурсами, як бази даних та файлові системи. Таку архітектуру ще називають «дворівневою». Програмні системи 3 дворівневою архітектурою відносно легко реалізовуються, але вони мають проблеми 3 масштабованістю. Якщо цей критерій є важливим (або навіть - вирішальним) у 
розроблюваній системі, використовують три- або багаторівневу архітектуру. При проектуванні УНЛК за основу було взято трирівневу (рис. 19.10).

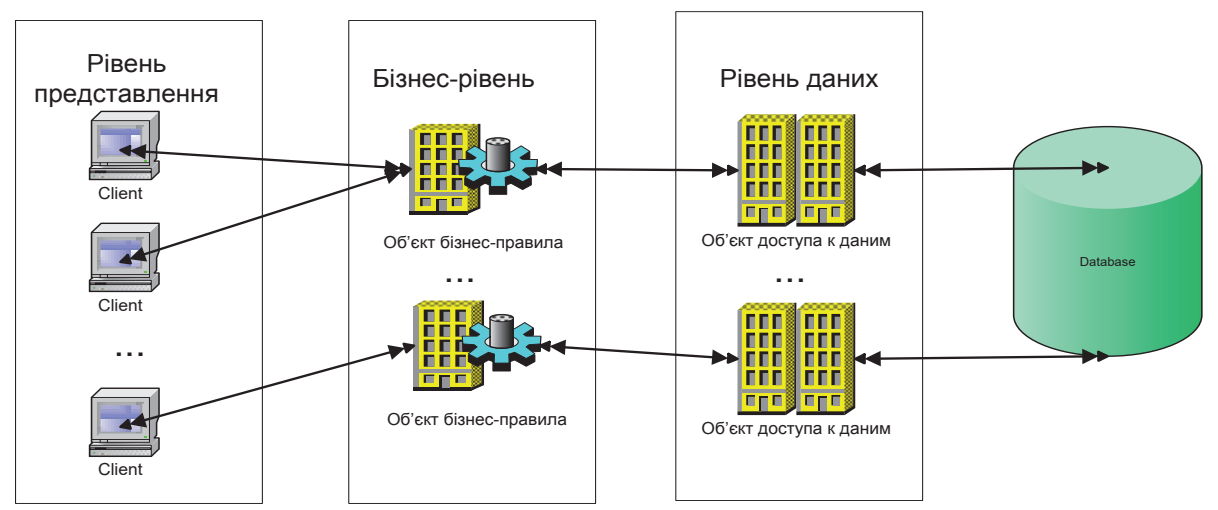

Рис. 19.10. Трирівнева архітектура лінгвістичного корпусу

Для реалізації підсистеми збереження даних в УНЛК використано SQL92сумісну систему Microsoft SQL Server ${ }^{93}$. Вагомими аргументами на користь зазначеної системи стали іiі модульна архітектура; здатність підтримувати велику кількість типів даних (в т.ч. власного розроблення); доступність інтерфейсів програмування для таких платформ, як .NET та Java, мов C, C\#.

Розроблення клієнтської частини (рівня представлення) та бізнес-рівня об'єктів електронної бібліотеки та лінгвістичної підсистеми, що включає алгоритми контролю та опрацювання даних, структурного маркування тексту, морфологічного аналізу, транскрибування та наголошення слів, індексування, пошуку та виділення контекстів, представлення сервісних функцій користувачеві, проводилось на платформі .NET з використанням мови програмування С\#.

Як зазначалось, УНЛК, як будь-який інший лінгвістичний корпус, структурно складається 3 двох підсистем - електронної бібліотеки та лінгвістичної підсистеми, інтегрованих у клієнтське ПЗ УНЛК, стартову сторінку якого наведено на рис. 19.11.

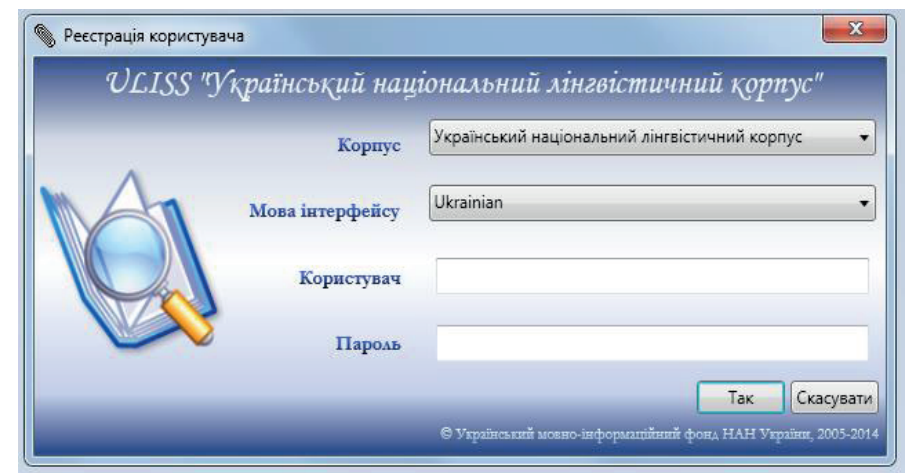

Рис. 19.11. Стартова сторінка УНЛК

${ }^{93}$ Microsoft SQL Server. URL: https://www.microsoft.com/en-us/sql-server/. 


\subsubsection{1. Організація збереження метаданих}

Ефективна робота електронної бібліотеки можлива лише за умови використання чіткої та прозорої схеми представлення метаданих об'єктів зберігання. Питання стандартизації опису даних розглядається як в межах кожної установи, так і на державному та міжнародному рівнях. Це питання є складним адже сучасні розвинені стандарти бібліографічного опису налічують тисячі полів. Їхня семантика не завжди однозначна, що може спричинити колізії при інтеграції ресурсів навіть за умови дотримання розробниками встановлених стандартів, таких, як міжнародний формат обміну бібліографічними даними ISO-2709 та формат бібліографічного опису UNIMARC. Як показує практика, при створенні колекцій об'єктів різнорідної природи для різних масивів об'єктів використовуються різні підмножини відповідного стандарту, що складають формат опису бібліографічних даних конкретної цифрової бібліотеки.

Пояснимо зазначене на прикладі. В електронній бібліотеці Фонду зберігаються тексти різних стилів - художнього, наукового, офіційно-ділового. Для бібліографічного опису художніх та наукових текстів використовуються такі поля, як 'жанр', 'стиль', 'УДК', 'автор', 'видавництво', 'місце видання', 'ISBN', 'рік видання' та ін. А ось бібліографічний опис нормативно-правових актів має інші поля: 'реєстраційний номер документа', 'орган державної влади', ‘дата прийняття', ‘чинність'. Тобто навіть однакові за природою інформаційні ресурси (в розглянутих випадках - природномовні тексти), можуть мати різний формат опису метаданих.

Розглянемо це питання 3 позиції системотехніки організації електронної бібліотеки. Якщо внутрішня структура зберігання метаданих «прив'язується» до якогось певного формату опису даних, при будь-якій зміні формату (навіть незначній) виникає проблема масштабованості системи. Зміна формату викликає лавиноподібну зміну всього програмного комплексу, що, у свою чергу, призводить до необхідності розроблення спеціальних програмних систем для різних колекцій, що робить процес розроблення та супроводження програмної системи фактично безперервним та нескінченним. Одним з підходів до вирішення зазначеної проблеми є перекладання забезпечення відповідності даних сутностям 3 рівня логіки роботи $з$ даними на рівень бізнес-логіки (рис. 19.12), завдяки чому структура спроектованої БД не залежить від формату опису об'єктів зберігання, що робить їі універсальним сховищем метаданих різної природи (формату). 


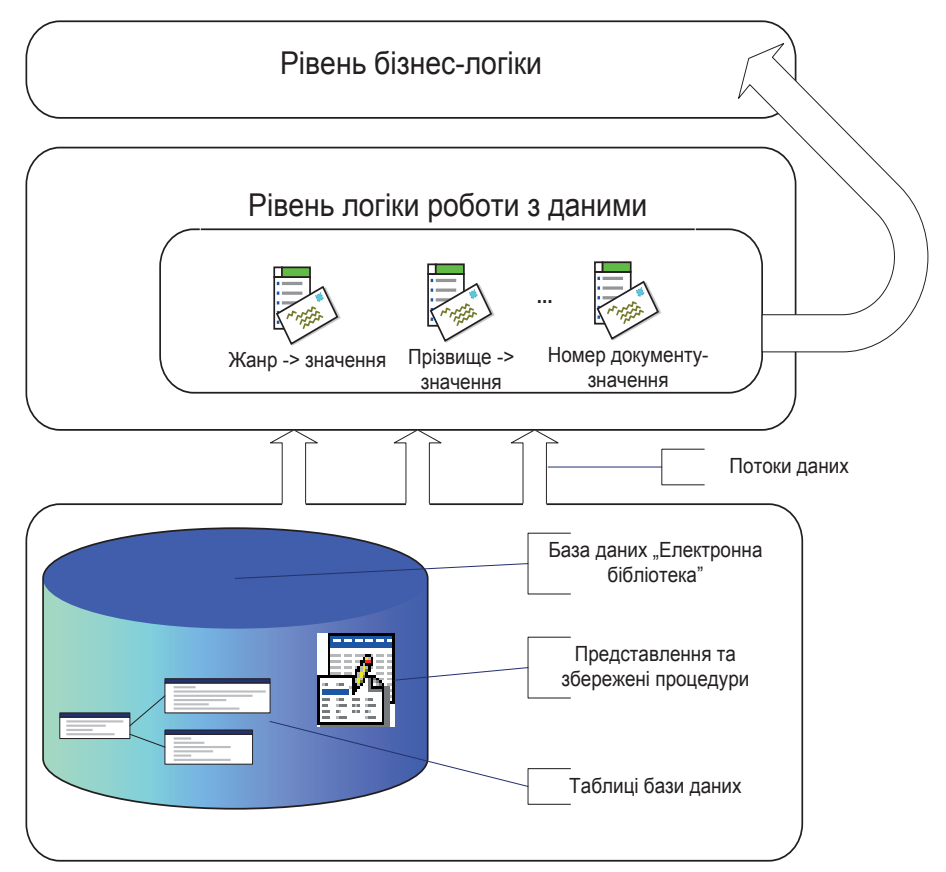

Рис. 19.12. Зміна підходу до збереження метаданих

Для подальшого розгляду структури БД електронної бібліотеки узгодимо деякі поняття:

Об'єкт зберігання - електронний ресурс, внесений до електронної бібліотеки як цілісна одиниця.

Характеристика - одиниця опису об'єкту зберігання, що забезпечує можливість його ідентифікації в пошукових та інших цілях.

Профіль - множина характеристик, якими описуються об'єкти зберігання спорідненої природи.

\subsubsection{2. Структура БД електронної бібліотеки}

На рис. 19.13 наведено загальну структуру БД електронної бібліотеки УНЛК із розширеними лінгвістичними функціями. 


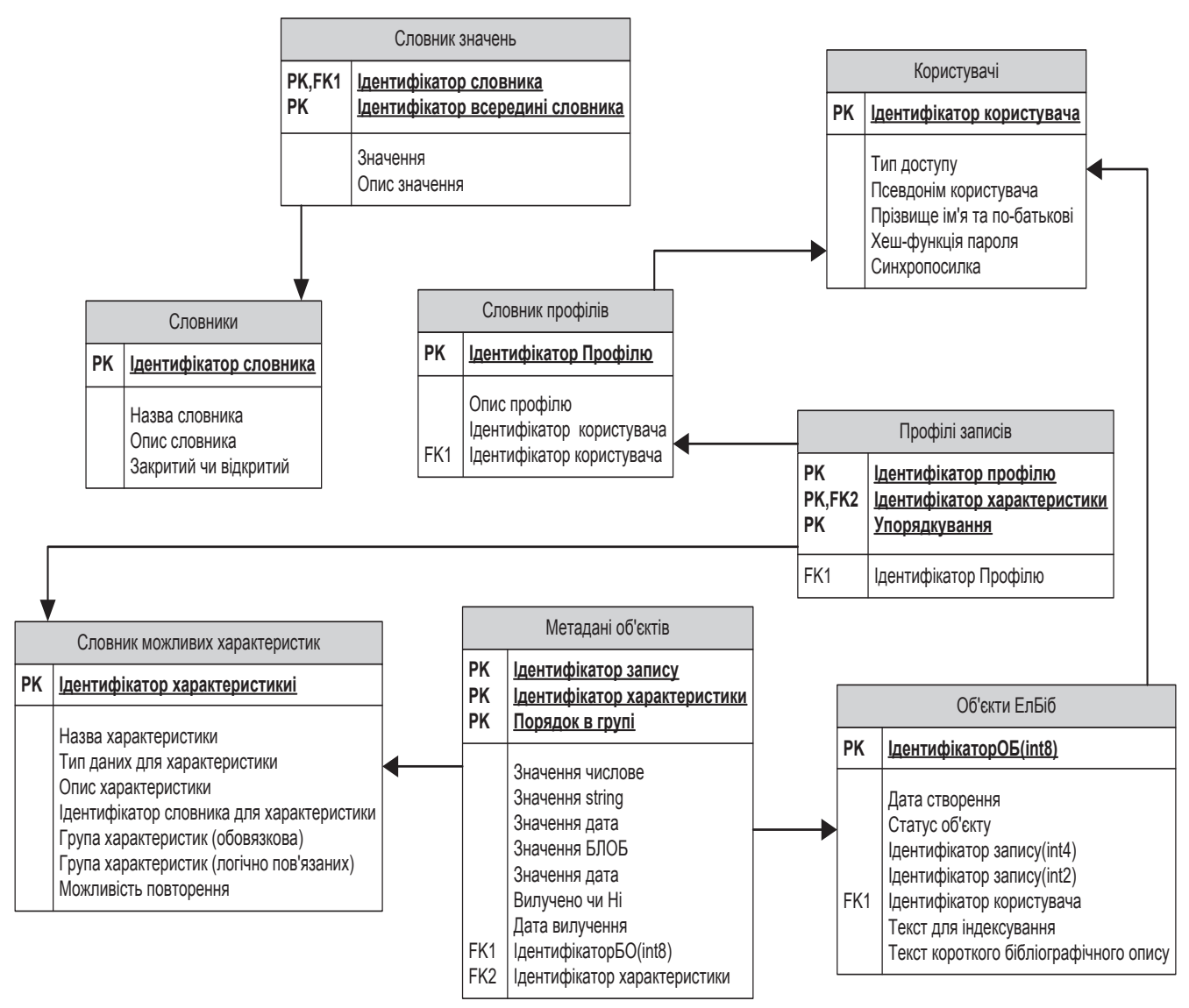

Рис. 19.13. Структура БД електронної бібліотеки УНЛК

Розглянемо структуру кожної з таблиць та взаємозв’язки між таблицями.

Поля таблиці:

\section{Таблиця «Словники»}

Назва поля

Bмicm

Ідентифікатор Унікальний в межах системи код.

\section{словника}

Назва

Унікальна в межах системи назва.

\section{словника}

Опис

\section{словника}

Закритий / відкритий

Додаткова інформація про словник (обсяг, призначення, джерело даних та ін.)

Відмітка про можливість зміни наповнення (множини значень) словника: 'true' - множина значень може бути зміненою користувачем 3 відповідними правами доступу; 'false' - множина значень не може бути зміненою, оскільки ініціюється при розробленні системи. 


\section{Таблиця «Словник значень»}

Поля таблиц̧і:

Назва поля

Bмicm

Ідентифікатор Зовнішній ключ, що реалізує зв’язок з таблицею «Словники». словника

Ідентифікатор Унікальний ідентифікатор кожного 3 елементів множини всередині значень словника.

словника

Значення Елемент множини значень словника.

Опис Додаткова інформація до значення зі словника.

значення

\section{Таблиця «Словник характеристик»}

Поля таблиці:

Назва поля

Ідентифікатор характеристики

Назва характеристики

Тип даних

Опис

характеристики

Ідентифікатор

словника для

характеристики

Можливість

повторення

Група

характеристик

(обов'язкова)
Унікальна назва харатеристики в межах системи.

Зазначається один 3 п'яти типів даних для характеристики: 'числовий', 'символьний', 'дата та час', 'шлях до файлу', 'BLOB'.

Додаткова інформація про характеристику, що пояснює специфіку іï використання та містить посилання на певний стандарт.

Позначка у цьому полі позначає, що внесена до словника характеристика може приймати значення лише зі словника.

Одне 3 булівських значень: 'true' - заборона повторення характеристики для одиниці зберігання; 'false' - кількість повторень не обмежується.

Одне й те ж значення для декількох характеристик визначає неможливість використання однієї 3 цих характеристик окремо. Наприклад, об’єкт «художній текст» може бути описаний з використанням таких двох характеристик: мова видання і тип мови видання, які об'єднані в одну групу. Це означає, що при внесенні до метаданих значення однієї 3 характеристик вимагає зазначення і другої характеристики. Аналогічно, при вилученні 3 опису однієї 3 характеристик групи призводить до вилучення всіх інших значень характеристик цієї групи.

Група Дозволяє об'єднати декілька характеристик в логічні групи. характеристик На відміну від обов'язкових, характеристики, об'єднані в (логічна) логічні групи, можуть існувати окремо одна від одної. Та 
якщо при описі об'єкту, використовуються декілька характеристик з однієї логічної групи, їхня послідовність повинна бути чітко визначеною.

\title{
Таблиця «Користувачі»
}

Поля таблииі:

Назва поля

Ідентифікатор користувача

ПІБ

Псевдонів

Тип доступу

Хеш-функція

паролю

Синхропосилка Значення синхропосилки для автентифікації користувача.

Унікальний код користувача в межах системи.

Прізвище ім'я та по-батькові користувача системи.

Ім'я користувача, яке використовується для доступу в комп'ютерну систему (login).

Ідентифікатор рівня доступу, що визначає привілеї користувачє Закодований пароль користувача.

Поля таблиці:

Назва поля

Ідентифікатор профілю

Назва профілю Опис профілю

\section{Таблиця «Словник профілів»}

\section{i:}

\section{Унильй код в межах системи \\ Bмicm}

Унікальний код в межах системи.

Унікальна назва профілю в межах системи.

Додаткові відомості про призначення профілю, дату створення тощо.

\section{Таблиця «Профілі»}

Поля таблиці:

Назва поля

Ідентифікатор профілю

Ідентифікатор характеристики

Упорядкування

\begin{abstract}
Bмicm
Зовнішній ключ, що реалізує зв’язок із таблицею «Словник профілів».

Зовнішній ключ, що визначає код характеристики в межах таблиці «Словник характеристик».

Порядок слідування характеристик в профілі.
\end{abstract}

\section{Таблиця «Метадані об'єктів»}

Поля таблиці:

Назва поля

Ідентифікатор запису

Ідентифікатор характеристики

\author{
Bмiсm
}

Зовнішній ключ, що реалізує зв'язок із таблицею «Об'єкти ЕлБіб».

Зовнішній ключ, що реалізує зв’язок із таблицею «Словник характеристик». 
Порядок в групі Порядок слідування метаданих об’єкта зберігання;

Значення Дані типу 'числовий'.

числове

Значення Дані типу 'символьний'.

символьне

Значення дати Дані типу 'дата'.

Значення blob Дані типу 'blob'.

\section{Таблиця «Об'єкти зберігання»}

\section{Поля таблиці:}

Назва поля

Bмicm

Ідентифікатор $\quad$ Унікальний код об’єкта зберігання в межах системи.

об'скта

зберігання

Дата створення Дата створення об'єкта зберігання в межах системи.

Ідентифікатор Зовнішній ключ, що реалізуе зв'язок 3 таблицею користувача «Користувачі» та слугує для збереження інформації про користувача, відповідального за створений об'єкт.

Статус об'скта Одне 3 трьох значень ідентифікатора поточного стану об'єкта: 'новий', 'редагується', 'редагування закінчено'.

Короткий Загальні відомості про об’єкт, які формуються на основі бібліографічний метаданих про об'єкт за певними правилами в залежності від опис об'єкта природи об'єкта.

Текст для Iдентифікатор blob-об'єкта, в якому збережено підготовлений індексування для індексування текст.

На рівні логіки роботи з даними реалізовані деякі функції та процедури, що забезпечують коректну роботу 3 даними та слугують для збереження їхньої цілісності. Так, наприклад, при вилученні характеристики 3 таблиці «Словник характеристик» відбувається каскадне вилучення всіх записів 3 таблиць «Профілі» та «Метадані об'єктів», які посилаються на цю характеристику.

\subsubsection{3. Рівень логіки застосунків}

Рівень логіки застосунків є ядром всього програмного комплексу та реалізує основні серверні функції. Як зазначалося, на сьогодні сервер Українського мовноінформаційного фонду функціонує під управлінням операційної системи Microsoft Windows Server 2016.

На рівні логіки застосунків виконуються основні лінгвістичні функції опрацювання тексту, підготовка даних до збереження в БД, моніторинг та адміністрування. 


\subsubsection{4. Рівень представлення даних}

Кожен рівень програмної системи несе своє функціональне навантаження, виконує процедури обміну, опрацювання та збереження даних тощо, але для кінцевого користувача $\epsilon$ відкритим лише рівень представлення даних, що робить питання організації інтерфейсу користувача одним із ключових при розробленні програмної системи.

У режимі адміністрування можливо здійснювати налаштування серверної частини програмного комплексу. Одним 3 етапів налаштування є визначення формату опису об'єктів, що зберігаються в БД. Ця операція полягає в заповнюванні полів спеціально розробленої програмної форми, до якої вноситься: назва характеристики, інформація стосовно додаткових домовленостей, відповідності стандарту, коментарі (пояснення) для користувачів, тип значень, яких може набувати певна характеристика. За результатами автоматично генеруються форми для введення значень, будуються пошукові запити, перевіряється коректність введення інформації, а при опрацюванні даних викликаються необхідні вбудовані функції (рис. 19.14).

Як зазначено в табл. «Словник характеристик», метадані бувають п’яти типів: 'символьний', ‘числовий', ‘дата', ‘шлях до файлу' та 'blob-об'єкт'. Тобто метаданими $є$ не лише текстові й числові дані, але й посилання на документи, що зберігаються в файловій системі сервера або ж будь-які двійкові дані, занесені в базу (фото, аудіо, відео і т.ін.) Деякі характеристики можуть набувати значення 3 лише обмеженої множини значень. Для зручності роботи 3 такими характеристиками в системі передбачена можливість підключення відповідних словників значень. Наприклад, до характеристики «мова видання» під'єднаний словник назв мов.

Іншим параметром характеристики, який адміністратор може змінювати в режимі редагування, є іiї логічна група. Деякі підмножини характеристик пов’язані в логічні групи, що означає обов'язкову наявність всіх характеристик логічної групи в описі об'єкта. Форми для занесення значень елементів групи генеруються окремо для кожної логічної групи.

Останнім параметром характеристики є можливість повторения, що визначає унікальність характеристики в межах опису одного об'єкта. 


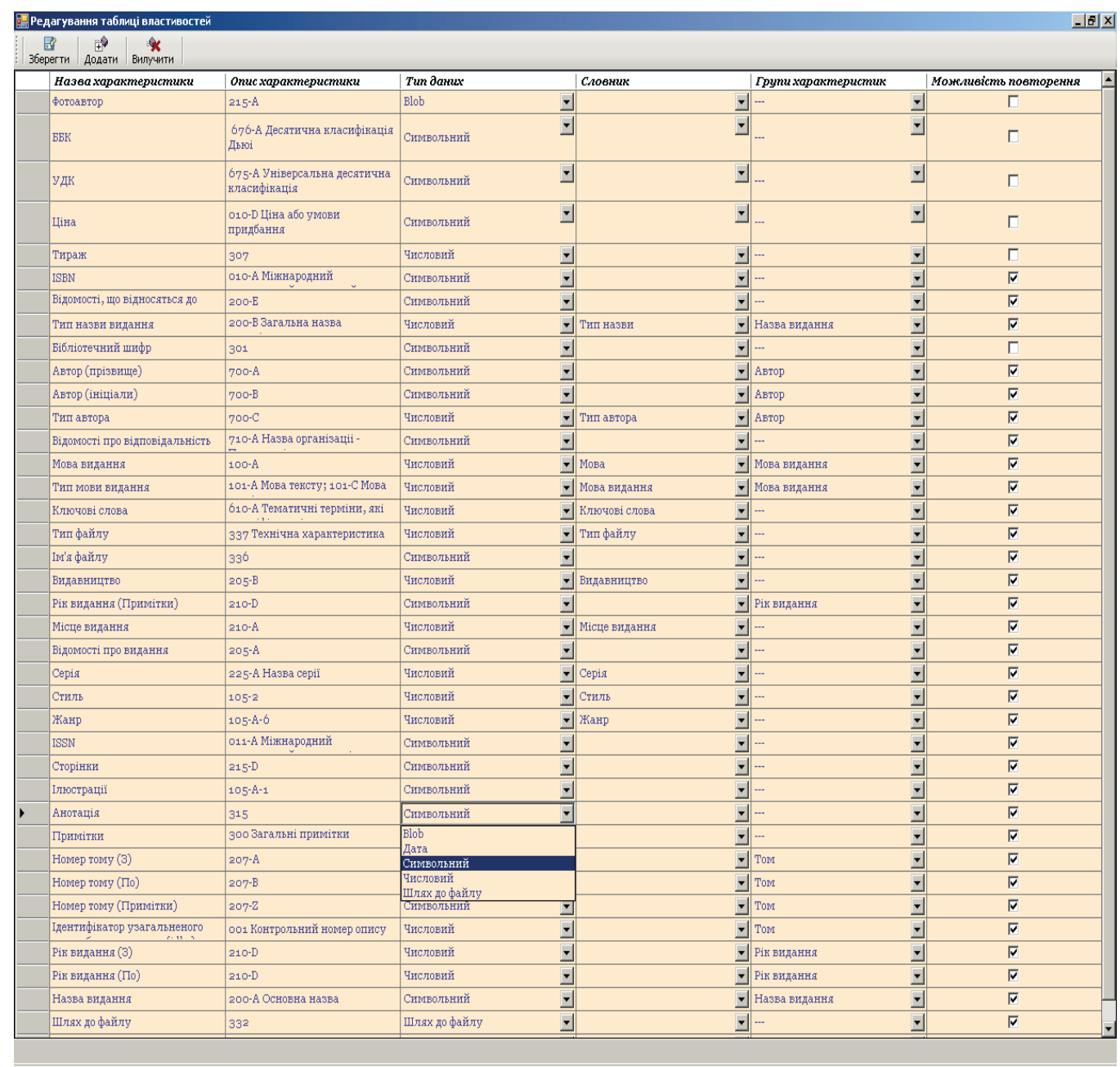

Рис. 19.14. Форма для редагування характеристик опису об'єктів зберігання

Бібліографу доступні для редагування словники лише відкритого типу, тоді як адміністратор системи має повноваження створювати нові або редагувати вже існуючі словники відкритого та закритого типу.

Важливим етапом налаштування системи $\epsilon$ створення профілей характеристик, що полягає в формуванні певних підмножин характеристик iз загальної множини (рис. 19.15). Для користувачів системи передбачена можливість самостійного налаштування пошукового профіля на їхніх комп'ютерах. 


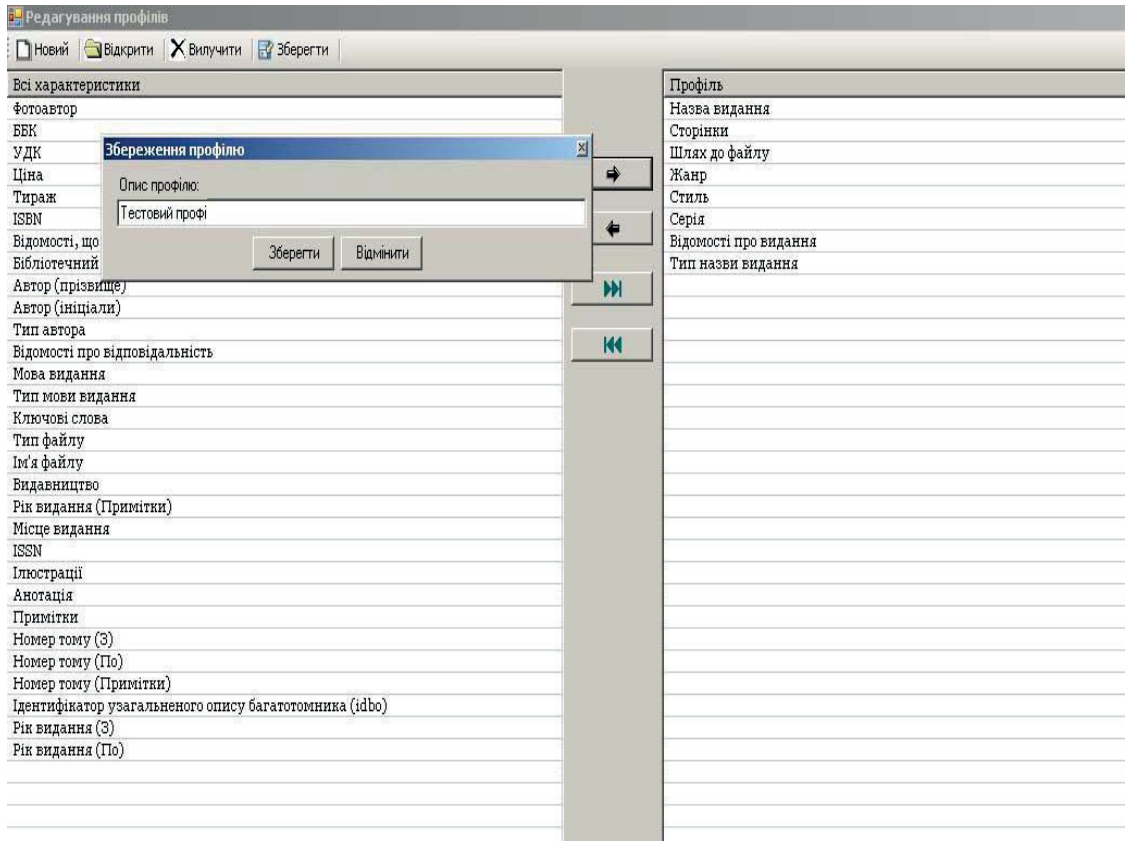

Рис. 19.15. Форма створення та редагування профілів системи

Адміністрування системи також полягає в заведенні інформації про користувачів до системи та визначенні рівня доступу кожного з них (рис. 19.16). Таких рівнів передбачено чотири: «читач»; «бібліограф»; «адміністратор»; «адміністратор системи».

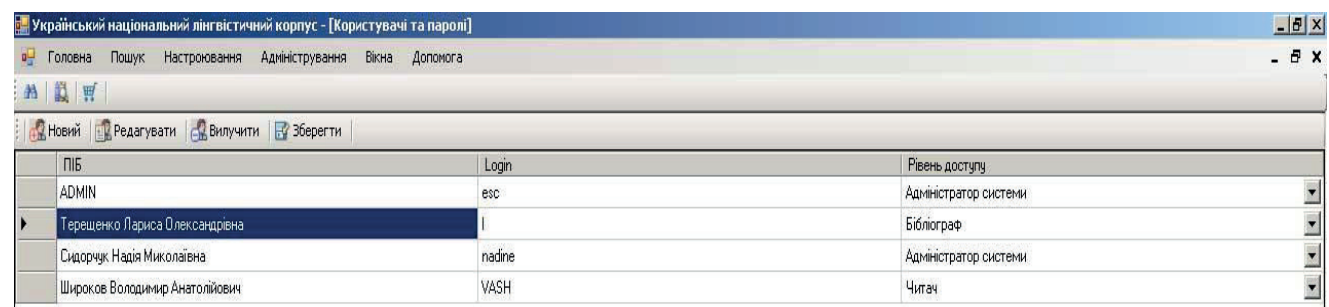

Рис. 19.16. Форма редагування інформації про користувачів УНЛК

Доступ до об’єктів зберігання здійснюється через пошукову підсистему. В УНЛК передбачено два види пошуку: 1) за бібліографічним описом (рис. 19.17); 2) повнотекстовий (за лінгвістичними параметрами).

Пошук за бібліографічним описом здійснюється за метаданими об’єктів зберігання. До них належать: назва видання; прізвище автора (редактора, укладача, колективного автора); стиль; серія; жанр; рік видання (або проміжок часу); анотація; примітки; відомості про видання; місце видання; видавництво; відомості про відповідальність; відомості щодо назви; ISBN чи ISSN. 
Параметри пошуку можуть задаватися в довільному поєднанні без урахування регістру шрифту.

Пошук за бібліографічним описом дозволяє формувати підмасив інформації для подальшого опрацювання. Користувачі будь-якого рівня доступу мають можливість самостійно визначати пошукові поля, а також об'єднувати результати пошуку за кожним критерієм (та / або).

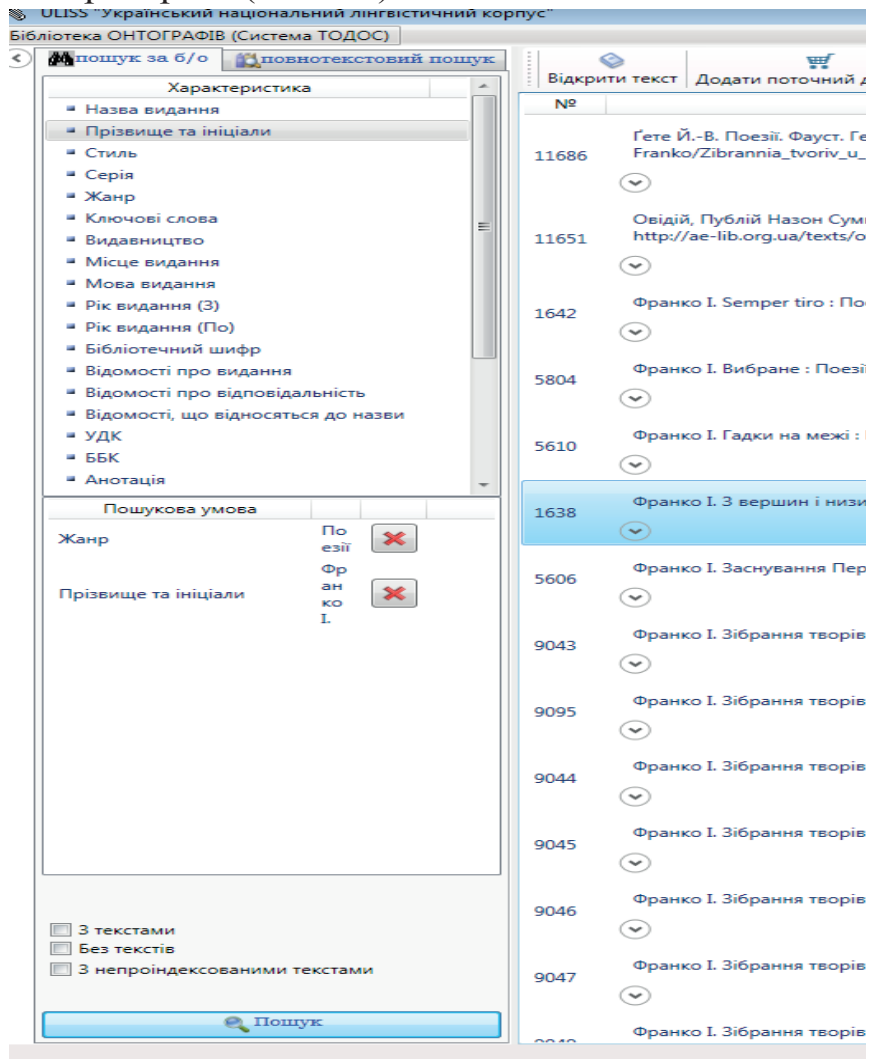

Рис. 19.17. Інтерфейс пошуку за бібліографічним описом

Результати пошуку представляються у вигляді списку бібліографічних описів (рис. 19.18). Користувачам рівня доступу «читач» надається можливість перегляду списку бібліографічних реквізитів для кожного об'єкта та ресурсу (повного тексту), а також можливість зберігання результатів пошуку в окремому файлі. Користувачам рівня доступу «бібліограф» та вищим доступні функції редагування бібліографічного опису та функції роботи з повнотекстовим індексом (створення індексу, вилучення, стиснення). 


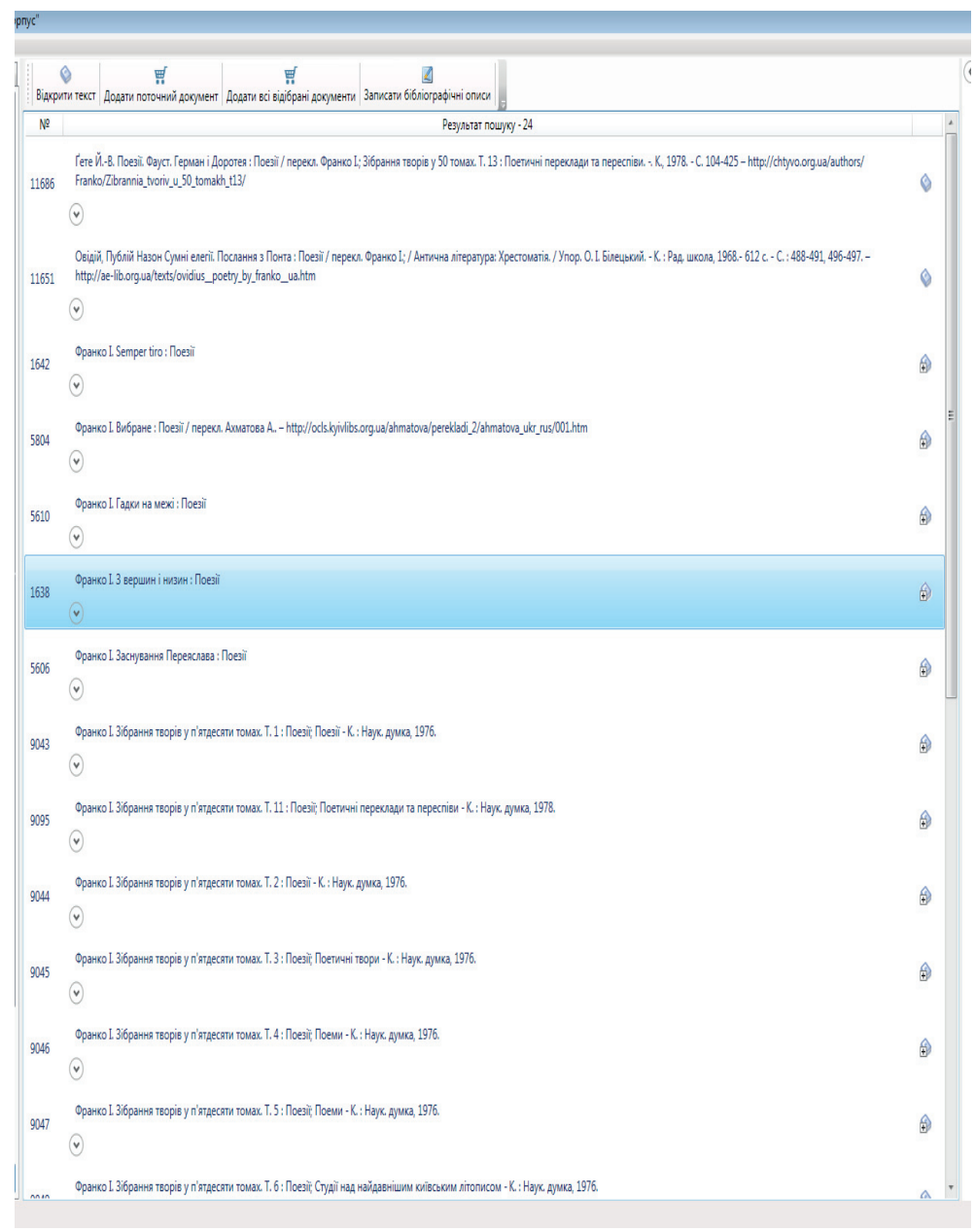

Рис. 19.18. Результати пошуку

Пошук за лінгвістичними параметрами забезпечується повнотекстовим індексом, що уможливлює: врахування порядку слів; пошук у визначеній підмножині документів; лематизацію (пошук по всім відмінкам кожного слова пошукового запиту); врахування синонімічних рядів.

Користувачеві забезпечуються такі можливості:

— перегляд бібліографічних описів об'єктів зберігання;

— доступ до відповідного об'єкта (тексту, архіву та ін.);

— робота з поточними документами (перегляд текстів, імпорт результатів у певні формати даних);

— перегляд бібліографічних реквізитів;

- отримання статистичних даних за результатами пошуку;

- перегляд множини контекстів, що відповідають заданим критеріям;

- прямий перехід до парадигматичного, синонімічного та тлумачного словників; 
- перегляд словозміни обраного слова;

- перегляд синонімічних рядів обраного слова.

Ще одним засобом для створення користувацьких наборів даних у системі $є$ тимчасове сховище - т. зв. «кошик». Користувач може відібрати об'єкти зберігання з різних пошукових запитів і зберегти образ даних для подальшої роботи 3 ними в інших сеансах. Користувачеві, що працює 3 об'єктами, занесеними у кошик, доступні всі базові операції (доступ до тексту, перегляд бібліографічного опису) та деякі додаткові (перегляд статистики, копіювання знайдених повнотекстових документів на визначені ним носії).

В УНЛК реалізовано різні види перевірок коректності складання бібліографічного опису, що забезпечують: виключення дублювання даних; можливість вибору із заданого переліку; відповідність шляху знаходження об’єкта до його опису; узгодженість типів; правильність написання ISBN (ISSN) тощо.

Таблиця 19.8. Відповідність елементів бібліографічного опису УНЛК стандарту UNIMARC (фрагмент)

\begin{tabular}{|l|c|}
\hline \multicolumn{1}{|c|}{ Опис поля } & UNIMARC \\
\hline Мова видання & $101-\mathrm{A}$ \\
\hline Мова оригіналу & $101-\mathrm{C}$ \\
\hline УДК & $675-\mathrm{A}$ \\
\hline Індивідуальний автор (прізвище) & $700-\mathrm{A}$ \\
\hline Індивідуальний автор (ім'я та по батькові) & $700-\mathrm{B}$ \\
\hline Другий автор (прізвище) & $702-\mathrm{A}$ \\
\hline Другий автор (ім'я та по батькові) & $702-\mathrm{B}$ \\
\hline Колективний автор (установа, підприємство) & $702-\mathrm{A}$ \\
\hline Назва книги (основна назва) & $200-\mathrm{A}$ \\
\hline Назва книги (паралельна назва) & $200-\mathrm{D}$ \\
\hline Відомості про видання і вихідні дані & $205-\mathrm{A}$ \\
\hline Перше місце видання & $205-\mathrm{B}$ \\
\hline Видавництво або видавнича організація & $205-\mathrm{B}$ \\
\hline Дата видання & $205-\mathrm{B}$ \\
\hline Кількісна характеристика (розмір в кілобайтах) & $215-\mathrm{D}$ \\
\hline Область серії (основна назва серії) & $225-\mathrm{A}$ \\
\hline ІSВN & $010-\mathrm{A}$ \\
\hline Тематична група томів (назва тематичної групи томів) & $610-\mathrm{A}$ \\
\hline Назва тому (позначка і порядковий номер тому) & $207-\mathrm{A}$ \\
\hline Редактор(и) (прізвище) & $702-\mathrm{A}$ \\
\hline Редактор(и) (ім’я та по батькові) & $702-\mathrm{B}$ \\
\hline Перекладач(і) (прізвище) & $702-\mathrm{A}$ \\
\hline Перекладач(і) (ім’я та по батькові) & $702-\mathrm{B}$ \\
\hline Автор(и) передмови, вступних статей (прізвище) & $702-\mathrm{A}$ \\
\hline Автор(и) передмови, вступних статей (ім’я та по батькові) & $702-\mathrm{B}$ \\
\hline Складач(і) (прізвище) & $702-\mathrm{A}$ \\
\hline Складач(і) (ім’я та по батькові) & $702-\mathrm{B}$ \\
\hline Ілюстратор(и) (прізвище) & $702-\mathrm{A}$ \\
\hline Ілюстратор(и) (ім’я та по батькові) & $702-\mathrm{B}$ \\
\hline Ключові слова & $615-\mathrm{A}$ \\
\hline & \\
\hline & \\
\hline
\end{tabular}




\begin{tabular}{|l|l|}
\hline Службова інформація (агентство) & $801-\mathrm{A}$ \\
\hline Шлях до файлу & $951-\mathrm{A}$ \\
\hline Відомості про відповідальність & $700-\mathrm{A}$ \\
\hline
\end{tabular}

Бібліограф, працюючи над формуванням або модифікуванням бібліографічного опису ЛК, має можливість бачити динамічно створюваний ним бібліографічний опис в тому вигляді, в якому його побачить користувач (рис. 19.19).

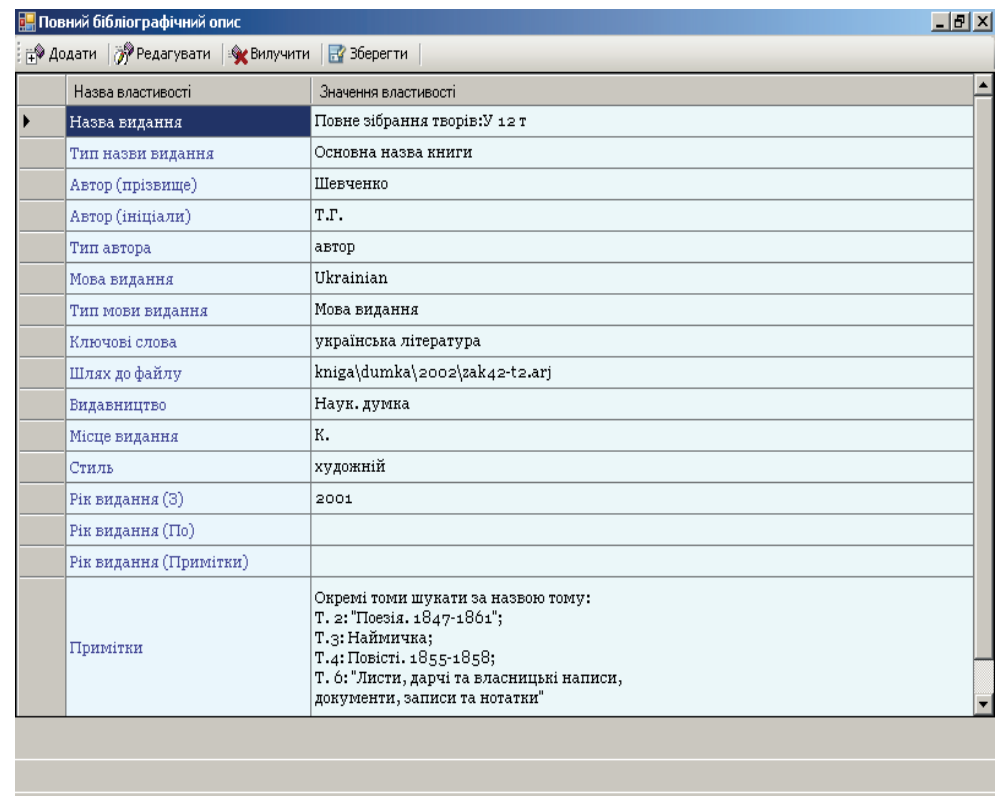

Рис. 19.19. Екранна форма перегляду та редагування бібліографічного опису

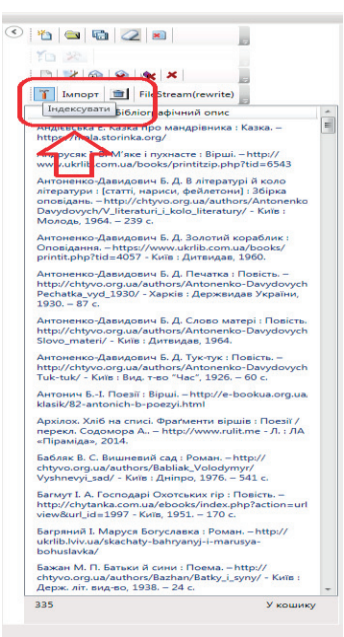

Рис. 19.20. Створення повнотекстового індексу для обраних об’єктів 


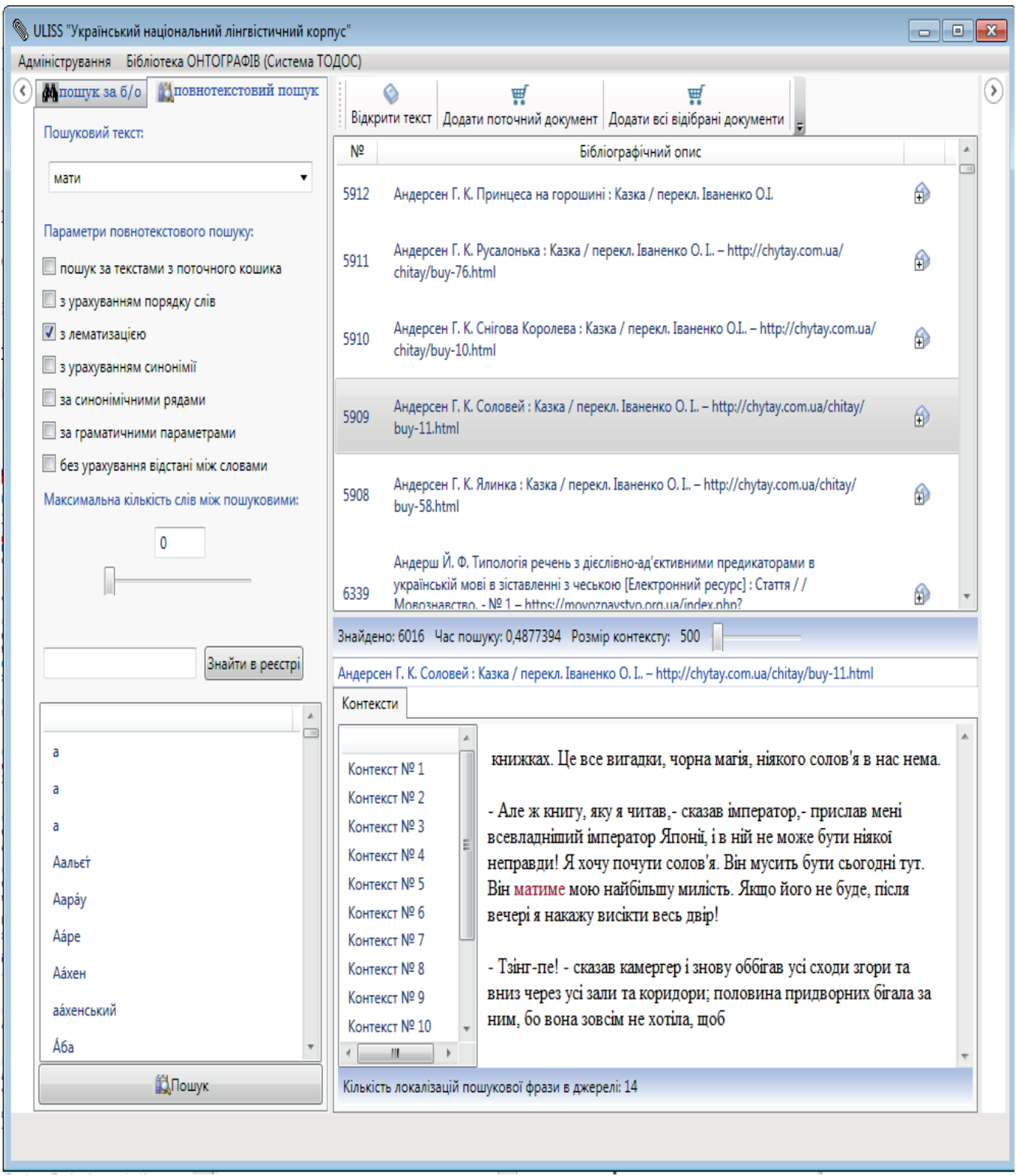

Рис. 19.21. Інтерфейс повнотекстового пошуку 


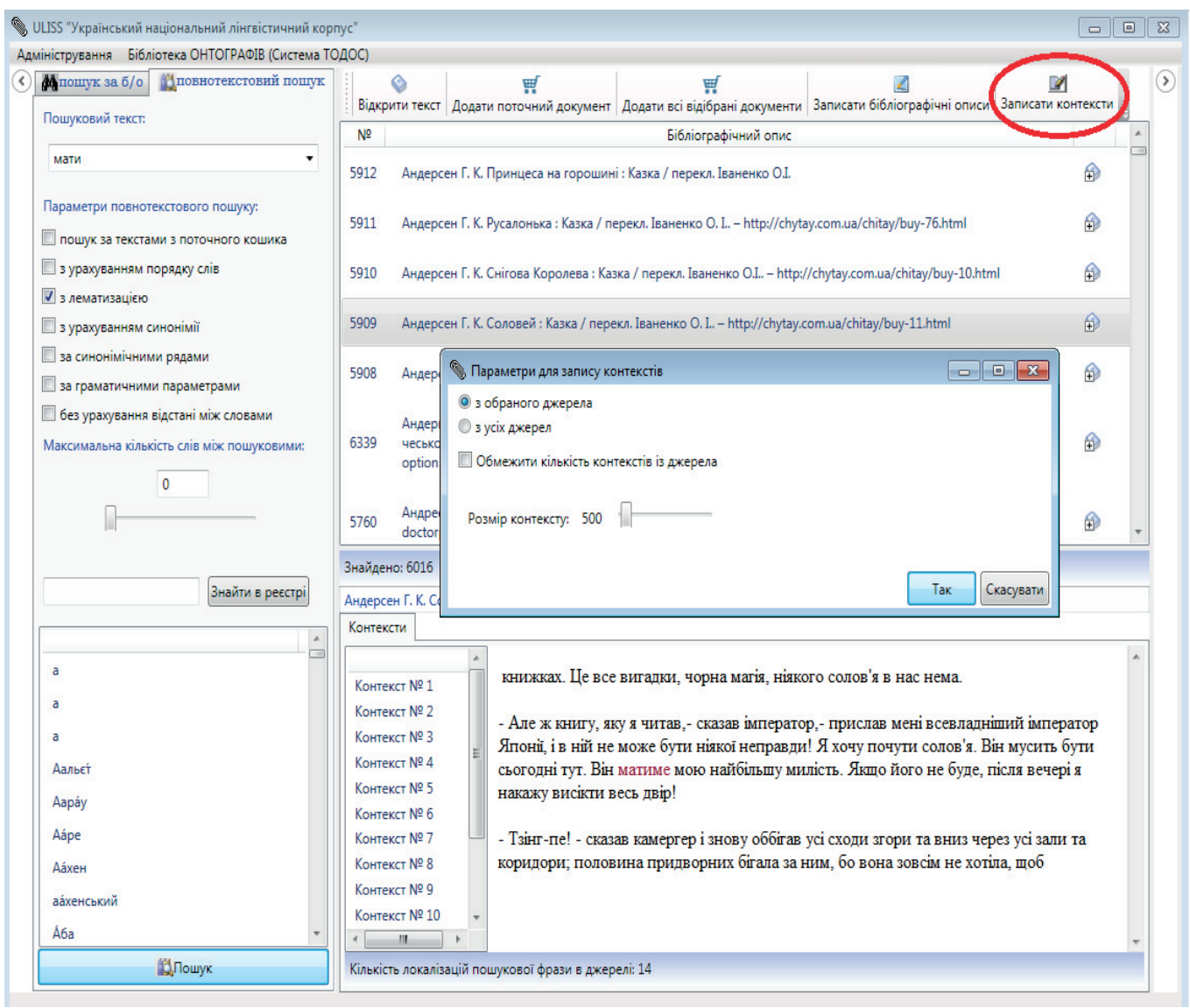

Рис. 19.22. Запис контекстів до файлу

\section{8. Системотехніка структурного маркування УНЛК}

Початковим етапом структурного маркування УНЛК $є$ попередня підготовка текстів, що полягає в виокремленні пробілами графемних слів, цифр, розділових знаків, лапок, дужок усіх видів, математичних знаків та ін.

Структурне маркування УНЛК включає:

1) структурування текстів за наявними елементами (розділ, частина, параграф, заголовок тощо);

2) виділення абзаців;

3) розпізнавання слів, написаних літерами не української абетки;

4) структурування тексту за реченнями з вказівкою початку і кінця речення;

5) виділення слів (фрагментів тексту), записаних з розрідженим інтервалом;

6) ідентифікацію текстових одиниць, які не мають статусу морфологічних i, відповідно, не можуть кодуватися за правилами морфологічного аналізатора;

7) маркування текстових слів 3 особливим алгоритмом присвоєння граматичних кодів при морфологічному маркуванні. 
Алгоритми структурного маркування враховують:

1) графемну структуру текстової одиниці (кількість символів у слові, графіку їхнього написання (кирилиця / латиниця, велика / мала буква, кількість великих букв, позиція великої букви, наявність дефіса), співвідношення голосних / приголосних у слові, наявність апострофа і його позицію, наявність конкретних графем або їхніх сполук у певній позиції);

2) контекстне оточення текстової одиниці (розділові знаки, слова певних графемних структур);

3) позицію текстової одиниці по відношенню до початку речення.

При створенні бібліотеки класів ПЗ автоматичного структурування тексту було розроблено бібліотеку класів, до складу якої входить клас TxtParser, інтерфейс для зовнішнього ПЗ, що виконує аналіз тексту, збереженому в текстовому форматі в стандарті кодування UTF16:

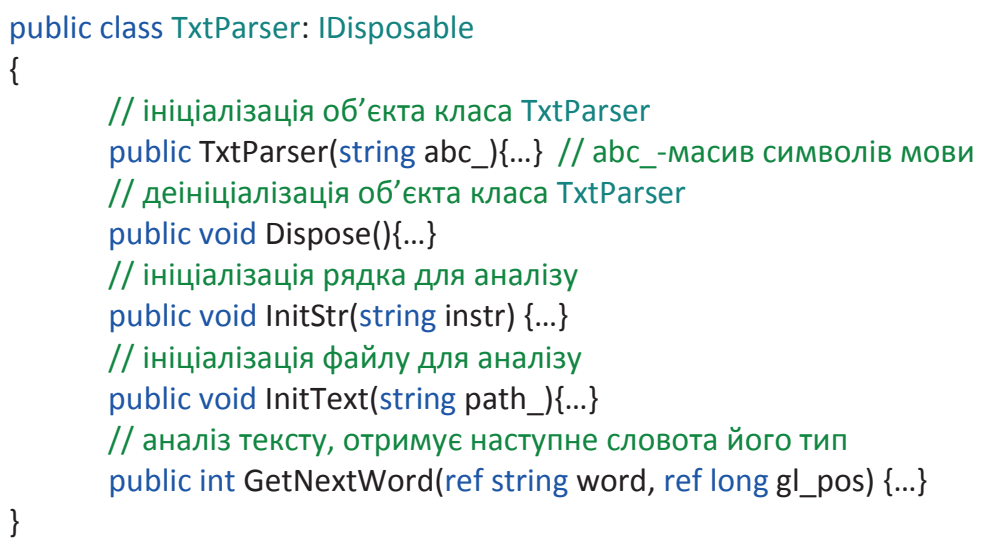

Власне аналіз виконує функція TxtParser.GetNextWord, результатом роботи якої є виокремлене слово з тексту, його тип та позиція в тексті.

У табл. 19.9 наведено типи слів поверненого масиву (return array) 3 TxtParser.GetNextWord, реалізовані в поточній версії структурного аналізатора УНЛК.

Таблиця 19.9

\begin{tabular}{|l|l|}
\hline $\begin{array}{c}\text { Тип } \\
\text { слова }\end{array}$ & \\
\hline 0 & Оброблення завершено \\
\hline 1 & Слово поточної мови \\
\hline 2 & Слово іншої мови \\
\hline 3 & Розділові знаки \\
\hline 4 & Скорочення \\
\hline 5 & Кінець речення \\
\hline 6 & Число \\
\hline 7 & Рубрикатор \\
\hline 8 & Ініціал \\
\hline 10 & Входження до слова символу з діапазону Combining Diacritical Marks \\
\hline 100 & Спецсимвол (\rاn) \\
\hline 101 & Табуляція \\
\hline
\end{tabular}




\begin{tabular}{|l|l|}
\hline 102 & Пробіл \\
\hline 105 & Роздільник \\
\hline 111 & Керуючий символ \\
\hline \multicolumn{1}{|c|}{ Спеціальні типи слів, символи яких не належать до природномовних алфавітів } \\
\hline 11 & Superscript \& Subscript \\
\hline 12 & Currency \\
\hline 13 & Combining Diacr. Marks for Symbols \\
\hline 14 & Letterlike Symbols \\
\hline 15 & Number Forms \\
\hline 16 & Arrows \\
\hline 17 & Mathematical Ops \\
\hline 18 & Miscellaneous Technical \\
\hline 19 & Control Pictures \\
\hline 20 & OCR \\
\hline 21 & Enclosed Alphanumeric \\
\hline 22 & Box Drawing \\
\hline 23 & Block Elements \\
\hline 24 & Geometric Shapes \\
\hline 25 & Miscellaneous Symbols \\
\hline 26 & Miscellaneous Symbols \\
\hline 27 & Dingbats \\
\hline 28 & Braille Patterns \\
\hline 29 & Braille Patterns \\
\hline 30 & СJK Radical Supplements \\
\hline 31 & Other CJK \\
\hline 32 & Alphabetic Presentation Forms \\
\hline 33 & Arabic Presentation Forms-A \\
\hline 34 & Combining Half Marks \\
\hline 35 & СJK Compatibility Forms \\
\hline 37 & Small Form Variants \\
\hline 38 & Arabic Presentation Forms-B \\
\hline & Halfwidth \& Fullwidth Forms \\
\hline & Specials \\
\hline
\end{tabular}

\section{9. Системотехніка морфологічного аналізатора}

Як зазначалося, система морфологічного аналізу УНЛК базується на розробленому у Фонді електронному граматичному словнику української мови. Інформація про слова, парадигматичні класи, властиві їм квазіфлексії та ін. зберігається в граматичній базі даних (gram_db). Ця БД складається з кількох зв’язаних між собою таблиць, що наводяться нижче. 


\begin{tabular}{|c|c|c|c|c|c|c|c|c|c|c|}
\hline дนวววย & 0 & 0 & 0 & 0 & 0 & 0 & 0 & 0 & 0 & 0 \\
\hline шuшosk & & & & & & & & & & \\
\hline गIq0.IdSI & 0 & o & 10 & 10 & 0 & 10 & 0 & 0 & 0 & 0 \\
\hline 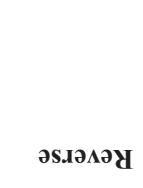 & $\sigma$ & o & $\sigma$ & 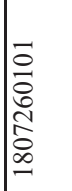 & 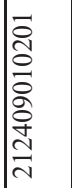 & 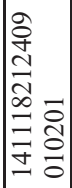 & 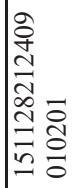 & 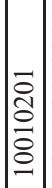 & 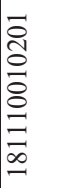 & 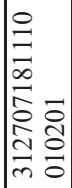 \\
\hline әм!ฺगVSI & 7 & 7 & 7 & 7 & 7 & 7 & 7 & 7 & 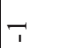 & 7 \\
\hline IPASI & 0 & o & 0 & 0 & 0 & 0 & 0 & 0 & 0 & 0 \\
\hline गॄЕ & 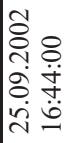 & 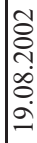 & 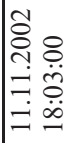 & 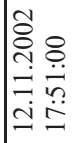 & 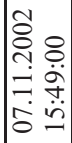 & 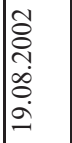 & 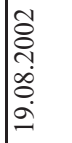 & 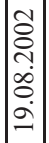 & 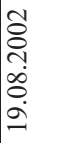 & 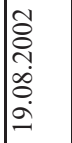 \\
\hline имо & 0 & & 0 & 0 & 0 & & & & & \\
\hline рIо $^{-}$шоч & - & 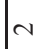 & m & t & in & 6 & $r$ & $\infty$ & $a$ & 0 \\
\hline woN & - & a & $m$ & + & in & 6 & $r$ & $\infty$ & $a$ & $\circ$ \\
\hline 1!ถి! & $\overline{0}$ & $\overline{0}$ & $\overline{0}$ & 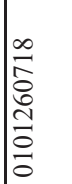 & 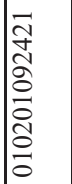 & 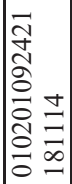 & 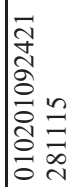 & 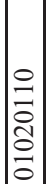 & 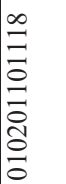 & 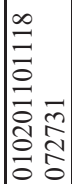 \\
\hline 9рІР! & & & & & & & & & & \\
\hline ऽрIગ!ష & & & & 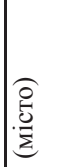 & & & & & 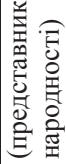 & \\
\hline əd $\mathcal{K}_{\mathfrak{l}}$ & 0 & 0 & 10 & $\frac{a}{6}$ & 8 & 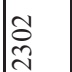 & $\stackrel{0}{\Sigma}$ & 8 & 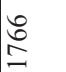 & 움 \\
\hline p.red & 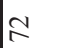 & $\approx$ & $\operatorname{si}$ & $\infty$ & $\infty$ & $=$ & $\infty$ & $\infty$ & r & $n$ \\
\hline 乙рІә! & - & a & $m$ & 10 & 0 & & & & & \\
\hline .џsəวy & $\pi$ & $\pi$ & $\approx$ & 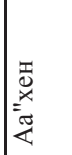 & 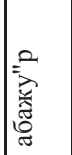 & 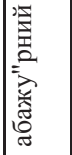 & 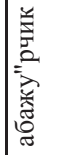 & 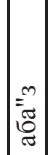 & 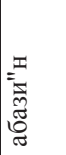 & 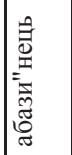 \\
\hline E & - & $\mathrm{a}$ & m & + & in & 6 & $n$ & $\infty$ & $a$ & 0 \\
\hline
\end{tabular}


Таблиця квазіфлексій «flex»

\begin{tabular}{|c|l|c|l|l|c|c|}
\hline ID & \multicolumn{1}{|c|}{ flex } & Field2 & Xmpl & Field4 & type & Part \\
\hline 37564 & і\#ь & 1 & & & 2131 & 1 \\
\hline 37565 & о\#і & 2 & & & 2131 & 1 \\
\hline 37566 & о\#і & 3 & & & 2131 & 1 \\
\hline 37567 & і\#ь & 4 & & & 2131 & 1 \\
\hline 37568 & і\#дю & 5 & & & 2131 & 1 \\
\hline 37569 & о\#і & 6 & & & 2131 & 1 \\
\hline 37570 & о\#е* & 7 & & & 2131 & 1 \\
\hline 37571 & іль & 1 & & & 2132 & 1 \\
\hline 37572 & олі & 2 & & & 2132 & 1 \\
\hline 37573 & олі & 3 & & & 2132 & 1 \\
\hline 37574 & іль & 4 & & & 2132 & 1 \\
\hline 37575 & іллю & 5 & & & 2132 & 1 \\
\hline 37576 & олі & 6 & & & 2132 & 1 \\
\hline 37577 & оле & 7 & & & 2132 & 1 \\
\hline
\end{tabular}

Поля таблиці «flex»:

Назва поля

ID

Унікальний ідентифікатор запису.

flex Квазіфлексія (символ «*» у полі 'flex' є ознакою рідковживаної форми слова; символ «^»- ознакою специфічної форми слова, що враховується при лематизації, але не відображається при формуванні повної парадигми слова).

Field2 Номер граматичної категорії (з таблиці «gr»).

xmpl Приклад слова.

Field4 Зарезервовано

type Номер парадигматичного класу.

part Частина мови (з таблиці gr).

Таблицю проіндексовано за полями: 'ID';'Field2'; 'type'; 'part'.

Таблиця номерів парадигматичних класів «indent»

\begin{tabular}{|c|c|c|c|c|c|c|}
\hline ID & type & indent & Field3 & Field4 & comment & intcomm \\
\hline 2130 & 2130 & 3 & 2 & 1 & & 0 \\
\hline 2131 & 2131 & 3 & 2 & 1 & & 0 \\
\hline 2132 & 2132 & 3 & 0 & 0 & & 0 \\
\hline 2133 & 2133 & 4 & 0 & 0 & & 0 \\
\hline 2134 & 2134 & 1 & 0 & 0 & & 0 \\
\hline 2135 & 2135 & 1 & 0 & 0 & & 0 \\
\hline
\end{tabular}

Поля таблиці «indent»:

Назва поля

Bмicm

ID Унікальний ідентифікатор запису.

type Номер парадигматичного класу. 
indent Відстань у літерах між кінцем слова та квазіосновою (наприклад: «дивовижність», 'tуре' 2130; квазіоснова - «дивовижн», квазіфлексія - «ість»).

Field3 Зарезервовано

Field4 Зарезервовано

comment Граматичний коментар до парадигматичного класу.

intcomm Зарезервовано

Таблицю проіндексовано за полями: 'ID (unique)'; 'type'; 'comment'; 'intcomm'.

Таблиця наголосів «accent»

\begin{tabular}{|c|c|c|l|l|c|c|c|c|}
\hline ID & indent1 & indent2 & indent3 & indent4 & accent_type & part & gram & xmpl \\
\hline 779 & 0 & -2 & & & 37 & & 15 & загнистися \\
\hline 780 & 0 & -2 & & & 37 & & 16 & \\
\hline 781 & 0 & 255 & & & 37 & & 19 & \\
\hline 782 & 0 & -1 & & & 37 & & 20 & \\
\hline 783 & 0 & -1 & & & 37 & & 21 & \\
\hline 784 & 0 & -1 & & & 37 & & 22 & \\
\hline 785 & 0 & 255 & & & 37 & & 26 & \\
\hline
\end{tabular}

Поля таблиці «accent»:

Назва поля

ID Унікальний ідентифікатор запису.

indent1 Кількість позицій, на яку зміщується перший наголос в слові 3 позиції, яку він займає в початковій формі ('0' позначає, що позиція наголосу не змінюється при відмінюванні слова; '255' що наголос зникає).

indent2 Те ж саме для другого наголосу в слові (якщо в початковій формі немає другого наголосу, але він з'являється в деяких словоформах граматичної парадигми, його позиція в такій словоформі відраховується від позиції першого наголосу в початковій формі).

indent3 Те ж саме для третього наголосу (якщо в початковій формі немає третього наголосу, але він 3'являється в деяких словоформах граматичної парадигми, його позиція в цій формі відраховується від позиції другого наголосу в початковій; якщо не було і другого наголосу, то від позиції першого).

indent4 Те саме для четвертого наголосу.

accent_type Номер класу наголосу.

part Частина мови.

gram xmpl Номер граматичної категорії (з таблиці «gr»). Приклад слова.

Таблицю проіндексовано за полями: 'accent_type'; 'gram'. 
Таблиця граматичних категорій «gr»

\begin{tabular}{|c|c|c|c|c|}
\hline $\begin{array}{c}\text { Num } \\
\text { of } \\
\text { table }\end{array}$ & Part of speech & Field4 & Field5 & Field6 \\
\hline 1 & іменник & $\mathrm{H} \mathrm{s}$ & $\mathrm{P}_{\mathrm{S}}$ & Д $\mathrm{s}$ \\
\hline 2 & прізвище & $\mathrm{H} \mathrm{s} \mathrm{m}$ & $\mathrm{Ps} \mathrm{m}$ & Д $\mathrm{s} \mathrm{m}$ \\
\hline 3 & прикметник & $\mathrm{H} \mathrm{s} \mathrm{m}$ & $\mathrm{Ps} \mathrm{m}$ & Д $\mathrm{s} \mathrm{m}$ \\
\hline 4 & займенник & $\mathrm{Hs}$ & $\mathrm{Ps}_{\mathrm{s}}$ & Д $\mathrm{s}$ \\
\hline 5 & займенник прикметниковий & $\mathrm{H} \mathrm{s} \mathrm{m}$ & P s m & Д $\mathrm{s} \mathrm{m}$ \\
\hline 6 & дієслово недоконаного виду & inf & $\begin{array}{l}\text { imp 2ps } \\
\text { sing }\end{array}$ & $\begin{array}{l}\text { imp 1ps } \\
\text { plur }\end{array}$ \\
\hline 7 & дієприкметник & $\mathrm{H} \mathrm{s} \mathrm{m}$ & $\mathrm{Ps} \mathrm{m}$ & Д s m \\
\hline 8 & дієслово доконаного виду & inf & $\begin{array}{l}\text { imp 2ps } \\
\text { sing }\end{array}$ & $\begin{array}{l}\text { imp 1ps } \\
\text { plur }\end{array}$ \\
\hline 9 & числівник кількісний & $\mathrm{H}$ & $\mathrm{P}$ & Д \\
\hline 10 & числівник порядковий & $\mathrm{H} \mathrm{s} \mathrm{m}$ & $\mathrm{Ps} \mathrm{m}$ & Д s m \\
\hline 11 & числівник типу "один" & $\mathrm{H} \mathrm{s} \mathrm{m}$ & P s m & Д $\mathrm{s} \mathrm{m}$ \\
\hline 12 & числівник типу "два" & $\mathrm{H} \mathrm{m}$ & $\mathrm{P} \mathrm{m}$ & Д $\mathrm{m}$ \\
\hline 13 & дієслово недоконаного та доконаного виду (2v) & inf & $\begin{array}{l}\text { imp 2ps } \\
\text { sing }\end{array}$ & $\begin{array}{l}\text { imp 1ps } \\
\text { plur }\end{array}$ \\
\hline 14 & прізвище типу 1 & $\mathrm{Hs}$ & $\mathrm{P}_{\mathrm{S}}$ & Д $\mathrm{s}$ \\
\hline 15 & прізвище типу 2 & $\mathrm{H} \mathrm{s} \mathrm{m}$ & $\mathrm{Ps} \mathrm{m}$ & Д s m \\
\hline 16 & іменник з прикметником & $\mathrm{Hs}$ & P s & Д $\mathrm{s}$ \\
\hline
\end{tabular}

Поля таблиці «gr»:

Назва поля

Number of table

Part of speech

FieldX

Код частини мови.

Назва частини мови.

Назва граматичної категорії.

Bмicm

Таблиця частин мови «parts» (фрагмент)

\begin{tabular}{|l|l|c|}
\hline ID & \multicolumn{1}{|c|}{ com } & Ac \\
\hline 5 & іменник жіночого роду & \\
\hline 6 & іменник жіночого роду, істота & \\
\hline 7 & іменник чоловічого роду, істота & \\
\hline 8 & іменник чоловічого роду & \\
\hline 9 & числівник кількісний & \\
\hline$\ldots$ & $\ldots$ & \\
\hline
\end{tabular}

Поля таблиці «parts»:

\section{Назва поля}

ID

part

com

ac

\section{Bмicm}

Унікальний код частини мови.

Скорочена назва частини мови.

Повна назва частини мови.

Додатковий коментар. 
Таблицю проіндексовано за полями: 'ID (unique)', 'com' .

До граматичної ЛБД також входить таблиця «TYP_REFL», що складається 3 одного поля 'tуре' і фактично $є$ переліком рефлексивних дієслівних парадигматичних класів.

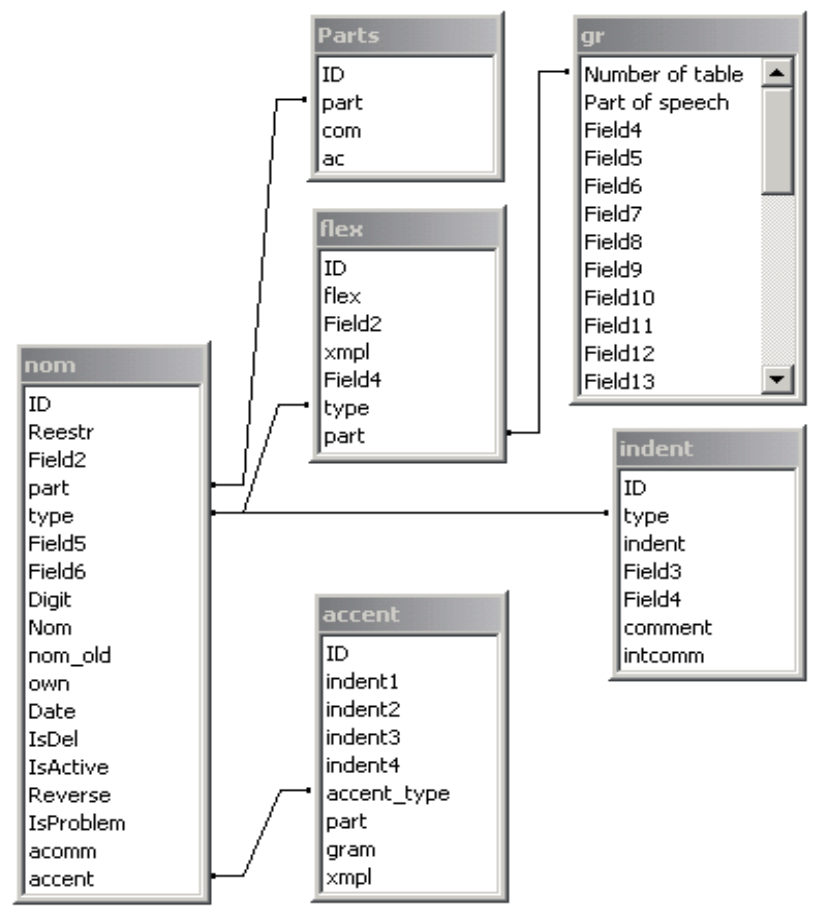

Рис. 19.23. Схема зв'язків між таблицями граматичного словника (спрощена)

Для роботи з граматичною ЛБД було створено клієнтську програму редагування граматичної ЛБД. Ця програма підтримує такі функції:

- перегляд реєстру граматичного словника, повної парадигми та транскрипції кожного слова;

- перехід до російського граматичного словника;

- сортування в прямому або інверсному режимі;

- фільтрування реєстру: за частинами мови, за парадигматичними класами, за омонімами, за власними назвами, за складеними словами, за активними / неактивними, вилученими / невилученими реєстровими одиницями;

— створення файлів БД морфологічного аналізу тексту;

- пошук слів у реєстрі;

- збереження в окремому файлі результатів пошуку;

- додавання, вилучення та редагування реєстрових слів; 
— додавання, вилучення та редагування парадигматичних класів та флексій в парадигматичних класах;

- перевірка наголосів;

- інші види перевірок та редагування.

Головне вікно програми наведено на рис. 19.24.

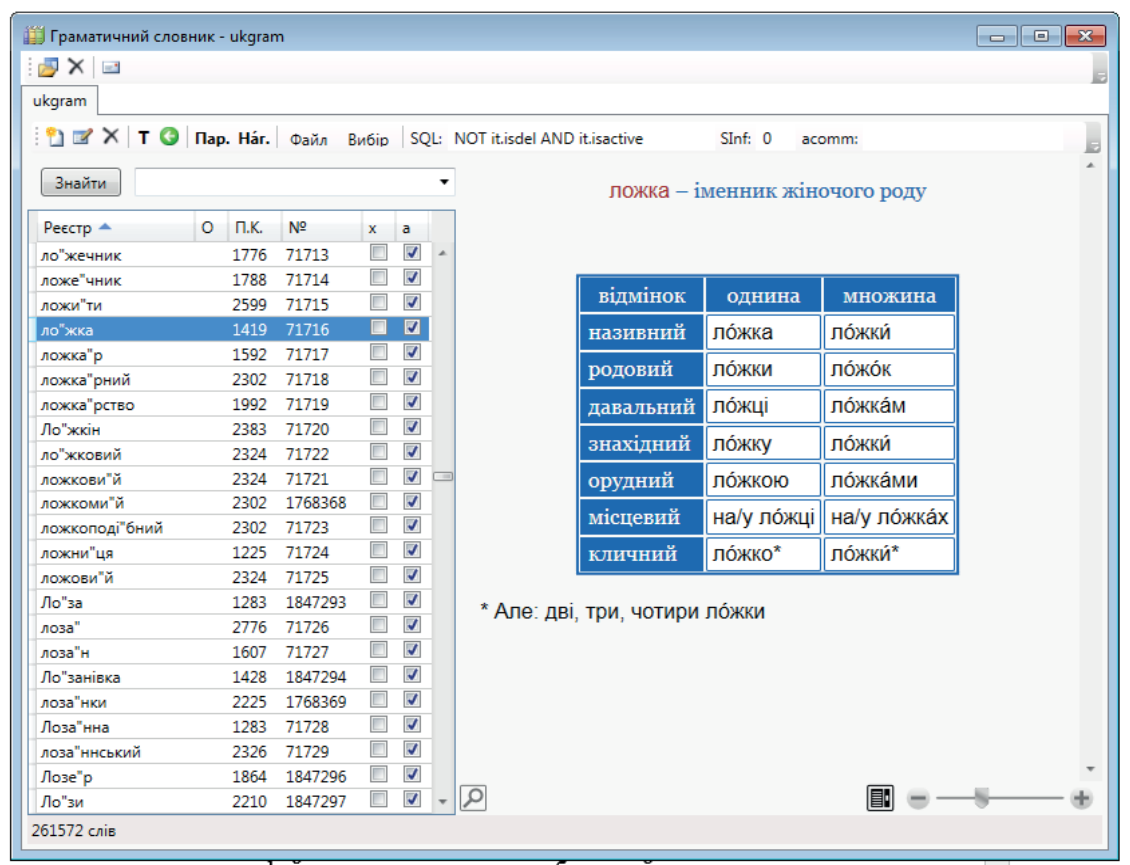

Рис. 19.24. Головне вікно ЕГС

Описана структура граматичної ЛБД є досить зручною для формування та редагування БД, але вона не є оптимальною для автоматичного опрацювання великих масивів морфологічної інформації, тому було розроблено оптимізовану структуру представлення морфологічної ЛБД, ПЗ для конвертації даних 3 реляційної СУБД у формат системи морфологічного аналізу, акцентуації та транскрибування, а також відповідну бібліотеку класів ПЗ. Інтерфейсом розробленої бібліотеки класів для роботи із зовнішнім ПЗ є клас Tmorph, що виконує морфологічний аналіз, та клас CUAccent, що виконує функції акцентуації та транскрибування:

public class TMorph: IDisposable \{

// ініціалізація об'єкта класа морфологічного аналізу public TMorph(...) \{...\}

// деініціалізація об'єкта класа морфологічного аналізу public void Dispose() $\{\ldots\}$

// пошук всіх словоформ та їхніх параметрів, які збігаються 


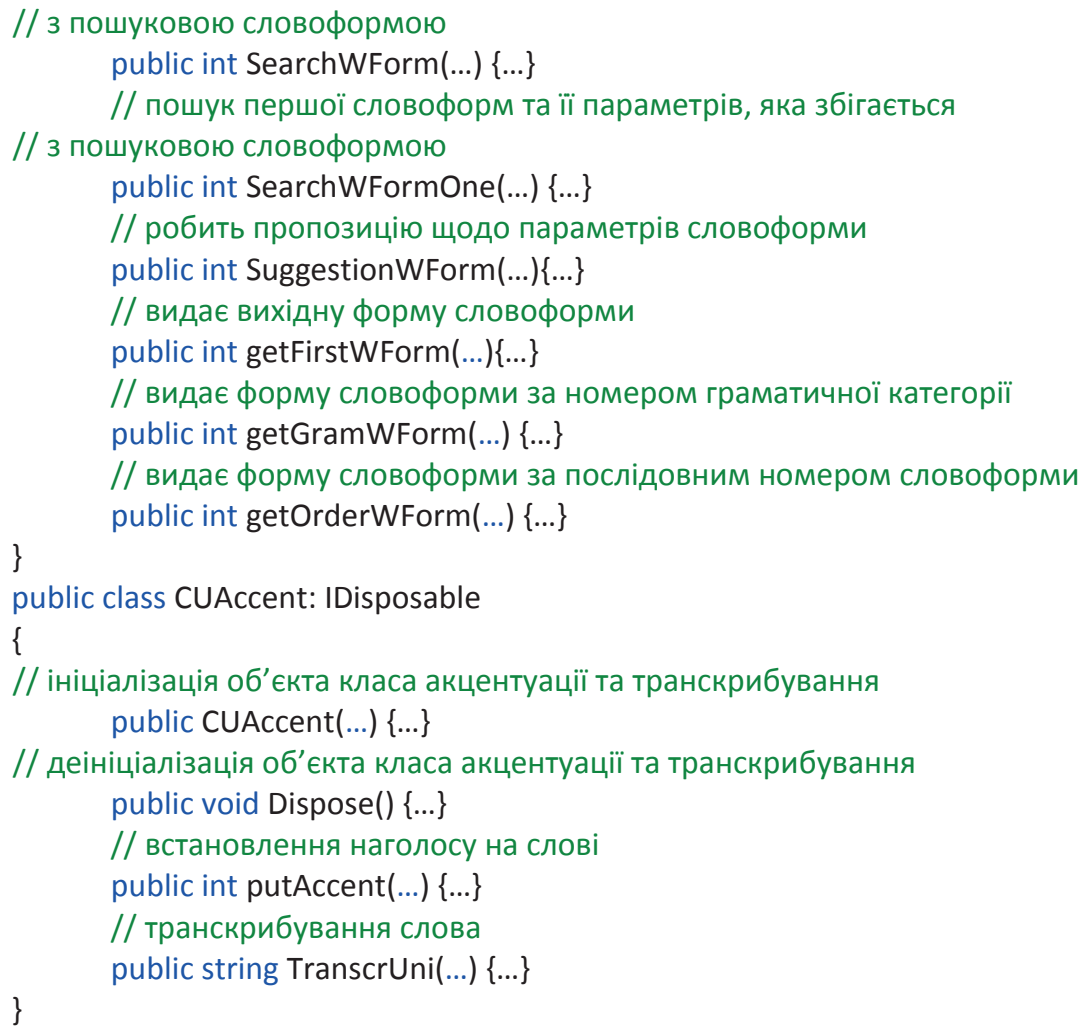

\subsection{0. Системотехніка семантичного аналізатора}

Семантичне маркування ЛК в автоматичному режимі на сьогодні є одним 3 нерозв'язаних завдань, що постали перед прикладною та корпусною лінгвістикою. Проте дуже складним завданням у технічному відношенні $є$ також створення інструменту для здійснення семантичного маркування ЛК і в режимі автоматизованому. Для цього необхідно мати репрезентативний комп'ютерний, добре структурований тлумачний словник, в якому було би виокремлено основні семантичні елементи, а також розробити засоби для його інтегрування до лінгвістичної підсистеми ЛК. Розроблена в Фонді ВЛЛ_СУМ $є$ науковопрактичним досягненням в зазначеному напрямку (див. Том 3 , Книга 1).

Вище йшлося про певну формалізовану схему, реалізація якої може надати універсальний інструмент семантичного маркування мовних одиниць тексту. Фактично, до таких одиниць варто віднести мовні одиниці будь-якого рівня, що мають властивість «мати значення». Зазначену властивість (точніше, відношення «форма-зміст», носієм якого є будь-який мовний знак), покладено в основу формалізації лексикографічних систем (до яких належать й лінгвістичні корпуси) та більш агрегованих структур (лексикографічних середовищ, числень тощо). 
Проте для здійснення семантичного маркування необхідно мати джерело необхідних семантичних структур - базову лінгвістичну систему.

Семантичне маркування може бути поширеним на різні значення мовних одиниць: фонетичні, морфологічні, лексичні, фразеологічні, синтаксичні тощо. Очевидно, що реалізація такого підходу надасть надзвичайно важливу інформацію щодо семантики тексту, процесів розуміння, співвідношення тексту та знання тощо. Тому розроблення інструментарію, спроможного забезпечити проведення навіть експериментальних досліджень у галузі маркування семантичних структур, насамперед лексичного рівня, $\epsilon$ науково та практично значимим завданням.

3 цією метою у Фонді використовується лексикографічна БД Л-системи тлумачного Словника української мови. Фахівець, що працює над семантичним маркуванням УНЛК, за допомогою спеціальної програми вибирає з будь-якого мікроконтексту значення (словникову дефініцію) певного слова, яке воно має саме в цьому мікроконтексті, і зберігає цей зв'язок у БД. Текст, отриманий після того, як всі його слова пройшли описану процедуру, стає семантично маркованим і може використовуватись як основа алгоритмів смислового пошуку.

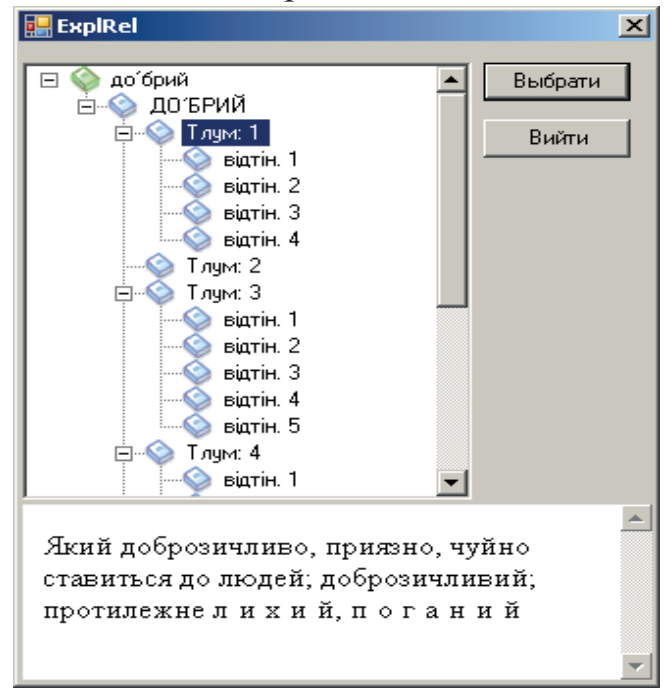

Рис. 19.25. Інтерфейс семантичного маркування тексту 


\section{РОздІЛ 20}

\section{КОРПУСНІ ТА СТАТИСТИЧНІ МЕТОДИ ДОСЛІДЖЕННЯ ТЕКСТІВ}

\section{1. Корпусні методи дослідження текстів}

\subsection{1. Дослідження граматичної омонімії на морфологічно анотованому корпусі текстів}

Завдання автоматичного морфологічного аналізу природномовних масивів, поставлене ще в минулому столітті ${ }^{94}$, особливої гостроти набуло на сучасному етапі розвитку корпусної лінгвістики.

Кінцевим результатом морфологічного аналізу $є$ морфологічно марковані тексти; чинником, на зменшення впливу якого на результат автоматичного морфологічного аналізу спрямовані основні дослідницькі зусилля, $є$ морфологічна омонімія (неоднозначність). Для морфологічного маркування ЛК розробляються різноманітні методи зняття морфологічної неоднозначності та визначаються підходи для їх реалізації. Наприклад, метод статистико-дистрибутивного аналізу ${ }^{95}$ вимагає наявності двох ЛК: корпусу із знятою вручну омонімією та корпусу з потенційною омонімією ${ }^{96}$.

Розроблення алгоритмів автоматичного знятя морфологічної неоднозначності потребує накопичення максимально повної інформації про потенційні можливості словникового складу мови стосовно прояву омонімії та мовленнєву характеристику цього явища. ${ }^{97}$ Такий підхід до опису омонімії передбачає врахування специфіки мови як абстрактної знакової системи та

${ }^{94}$ Пиотровский Р. Г. Инженерная лингвистика и проблемы искусственного интеллекта. Лингвистические проблемы искусственного интеллекта. Москва, 1980. С. 157-189; Белокриницкая С. С. Различные типы омонимии и способы их различия при машинном переводе. Вопросы языкознания. № 2, 1960. С. 97-102.

95 Федоров Е. Б. Омонимия и ИПС с автоматическим индексированием. Информационные прочессы и системыл. НТИ. Сер. 2. № 7. 1973. С. 19-25; Морфологический анализ научного текста на ЭВМ. Київ: Наукова думка, 1989. 264 с.; Кисилев А. Н. Предварительное разрешение омографии как основа реализации соответствия между частями речи и членами предложения в системе АМП. Омосемия и омография в естественных и машинных языках. Сб. научн. трудов. Дальневосточный научный центр АН СССР, 1986. С. 150-159.

96 Ляшевская О. Н., Плунгян В. А., Сичинава Д. В. О морфологическом стандарте Корпуса современного русского языка. Научно-техническая информация. Сер. 2. Информационные процессы и системы. № 6, 2005. С. 2-9.

${ }^{97}$ Наприклад, для російської мови на базі граматичного словника А. А. Залізняка було створено Словарь омонимичных словоформ русского языка. Москва, 2001. URL: http://cfrl.ruslang.ru/homoforms/index.htm. 
мовлення як конкретної реалізації цієї системи, тобто власне мовно-мовленнєве співвідношення розглядається як опозиція потенції та іiі реалізації. Мовним аспектом явища морфологічної омонімії $є$ система потенційно можливих типів морфологічних омонімів, встановлених на основі граматичного словника. Мовленнєвий аспект морфологічної омонімії в українській мови може бути дослідженим лише 3 позиції реалізації іiі можливостей у текстах реальної складності.

Зважаючи на масштабність завдань, постає нагальна потреба у побудові ЛБД, яка би представляла явище морфологічної омонімії в мові та мовленні на достатньо репрезентативному мовному матеріалі. ЛБД у такому випадку повинна забезпечувати:

- представлення реєстру морфологічно неоднозначних словоформ в сучасній українській мові;

- типізацію та моделювання морфологічних омонімів;

- надання статистичних відомостей щодо омонімів у стилістично диференційованих текстах корпусу;

- відповідність кожній із моделей морфологічних омонімів контекстів їхньої реалізації.

У Фонді реалізація такої ЛБД стала можливою завдяки розробленню та впровадженню системи автоматичного морфологічного аналізу; словника словоформ, створеного на основі ЕГС української мови та стилістично диференційованого корпусу текстів. Останній виступає і як інструмент для створення УНЛК, і як результат лінгвістичних досліджень 3 використанням УНЛК.

\subsection{2. Визначення потенційних типів морфологічних омонімів в українській мові}

Потенційні типи морфологічних омонімів української мови, що задаються іiї граматичною системою, кількісні та структурні характеристики цих типів визначалися на матеріалі словника словоформ, сформованого на основі розробленого у Фонді ЕГС. Повнота опису словозмінної системи української мови в ЕГС надає підстави стверджувати, що побудований словник словоформ (CC) достатньо точно репрезентує систему морфологічної омонімії української мови.

Формування списку омографів здійснювалося за допомогою розробленої у Фонді програми автоматичного морфологічного аналізу тексту (АМА). У системі АMА для подання граматичної інформації про належність неомонімічної словоформи до певного лексико-граматичного класу та конкретизації іiі граматичного значення в тексті використовуються двосимвольні 
коди. Перший символ коду вказує на частиномовну характеристику словоформи, другий - на ії граматичне значення.

Для омонімічних одиниць тексту система АMА будує ланцюжок двосимвольних кодів, що відповідають усім потенційно можливим граматичним значенням словоформи, які можуть реалізуватися нею в мовленні. Наприклад, словоформі вчений відповідає такий ланцюжок <АНЈН>, що означає: $\mathrm{AH}-$ ад'єктив, називний відмінок, чоловічий рід, однина, ЈH - іменник, чоловічий рід,

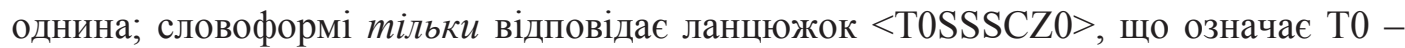
прислівник, SS - підрядний сполучник, SC - сурядний сполучник, Z0 - частка ${ }^{98}$. Кожен такий ланцюжок $є$ послідовністю пар символів, причому кожна така пара ${ }^{99}$ $€$ кодом «елементарного» граматичного значення. Перестановка цих двосимвольних кодів всередині ланцюжка не міняє його значення, отже надалі будемо вважати, що ланцюжок задається 3 точністю до перестановки двосимвольних кодів. У такий спосіб, наприклад, ланцюжки <АAМА $>$ та $<$ МААА $>$ вважаються тотожними.

Завдання Фонду полягало в проведенні обчислювального експерименту, за результатами якого визначались ланцюжки кодів, що реально реалізуються в лексичній системі української мови.

Експеримент здійснювався у такий спосіб. Реєстр ЕГС обсягом 171620 лексем (без урахування власних назв) за допомогою програми синтезу словозмінних парадигм ${ }^{100}$ було розгорнуто в список словоформ обсягом 3094174 одиниць. За результатами автоматичного морфологічного маркування 1554372 словоформам з 3094174 було однозначно поставлено у відповідність омонімічні коди за сформульованими вище правилами.

Дослідження морфологічної омонімії в українській мові спиралося на поняття: омонімічний ряд (ОР), модель морфологічних омонімів (ММО); тип морфологічних омонімів (ТМО).

Основним структурним елементом омонімічної системи мови визначено омонімічний ряд як «сукупність слів або словоформ однієї мови в той самий період iii існування, що тотожні в плані вираження, але істотно різняться між

98 Див. про це докладно в роботі Шипнівська О. О. Формування реєстру омографів сучасної української мови. Мовні та концептуальні картини світу: зб. наук. праць. - Вип. 14. Книга 2. Київ: Видавничий дім Дмитра Бураго, 2004. С. 255-259.

${ }^{99} \mathrm{У}$ межах розділу, незважаючи на прийняту систему кодування, при розгляді типів морфологічних омонімів дієслова доконаного та недоконаного виду позначаємо символом Д, всі іменники символом I, прикметники та дієприкметники об'єднуємо в один лексикограматичний клас - ад’єктив.

${ }^{100}$ Шевченко I. Автоматична парадигматизація лексичних одиниць у правописній системі української мови. Тези наукової конференції з проблем сучасного українського правопису i термінології (3 нагоди 70-ліття першої Всеукраїнської правописної конференції у Харкові 1927 р.). Київ, 1997. С. 99-100.; Шевченко І. В. Алгоритмічна словозмінна класифікація української лексики. Мовознавство. № 4-5, 1996. С. 40-44. 
собою в плані змісту» ${ }^{101}$. При описуванні системи морфологічних омонімів тотожність у плані вираження розумілась як однаковий графемний склад морфологічних омонімів, а різниця в плані змісту - як відмінності в їхньому граматичному значенні. Отже, омонімічний ряд являє собою сукупність морфологічно неоднозначних, графічно тотожних одиниць, об’єднаних однією формою.

Реєстр омонімічних рядів - 610612 одиниць, представлених у словнику словоформ, було сформовано шляхом зведення в одержаному списку графічно тотожних словоформ. У дослідженні представленням омонімічного ряду $\epsilon$ словоформа $з$ приписаним їй омонімічним кодом. Зрозуміло, що довжина такого коду більше 2. Так, ОР <теорії> \{mеорії - ім., ж. р., Н. в., мн. (FH), mеорії - ім., ж. р., Д. в., одн. (FC), теорії-ім., ж. р., М. в., одн. (FF), теорії-ім., ж. р., Р. в., одн. (FB), теорї - ім., жін. р., 3. в., мн. (FK), теорії - ім. жін. р. К. в., мн. (FN)\} у списку омонімічних рядів поданий як теорії $<$ FHFCFFFBFKFN $>$, аналогічно ОР $<$ спверх > \{поверх - ім., чол. р., 3. в., одн. (MD), поверх - ім., чол. р., Н. в., одн. (MА), поверх - присл., (Т0), поверх - прийменник (РВ)\} у списку подається як поверх $<$ MDMAT0РB $>$.

Список моделей морфологічних омонімів, представлених у словнику словоформ, формувався за списком попередньо виділених омонімічних рядів шляхом зведення омонімічних рядів 3 однаковими омонімічними кодами. У результаті було одержано список з 1486 різних структурних моделей.

Омонімічні коди, поставлені у відповідність омонімічним рядам, $\epsilon$ формальним представленням структурних моделей морфологічних омонімів, тобто модель репрезентує усі морфологічні функції, які можуть реалізувати в мовленні елементи відповідного омонімічного ряду. Наприклад, для словоформи mеорії - модель - <FHFCFFFBFKFN >, для словоформи поверх $-<$ MDMAT0РВ $>3$ відповідними граматичними значеннями.

Поняття типу морфологічних омонімів використовується у дослідженнях Фонду для відділення міжчастиномовних граматичних омонімів від тих, що представляють омонімію форм у парадигмі слова в межах одного граматичного класу. Омонімічний тип у такому випадку відображає збіг граматичних властивостей лише на рівні морфологічних класів, функцію яких може виконувати омонім, без урахування конкретного граматичного значення. Формальною процедурою виділення типів морфологічних омонімів $\epsilon$ перетворення омонімічного коду, що представляє ТМО, з ланцюжка їхніх перших

${ }^{101}$ Малаховский Л. В. Теория лексической и грамматической омонимии. Ленинград: Наука, 1990. 240 с.; Малаховский Л. В. Омонимическая группа как лексическая микросистема. Лингвистические исследования. Вопросы строя индоевропейских языков. Ч. 2. Москва, 1975. C. 184-194. 
символів, які й репрезентують можливості омоніма щодо актуалізації ним в тексті його частиномовних значень.

Так, за словником словоформ дві моделі $-<$ UAMDMASC $>$ (наказ. спосіб, дієсл. недок. в., друга особа одн.; іменн., 3. в., чол. р., одн.; іменн., Н. в., чол.. в., одн.; сполучн.) та <UAFKSCVA> (наказ. спосіб дієсл. док. та недок. в., друга особа одн.; іменн., жін. р., 3. в., множ.; сполучн.), представляють два омонімічні ряди словоформ ніж та мов, що належать до типу морфологічних омонімів дієслово / іменник / сполучник (ДIS).

За результатами аналізу отриманих моделей з позиції представлення ними типів морфологічних омонімів на рівні граматичних класів, встановлено, що міжчастиномовна омонімія описується 820 моделями 31486 . Ці моделі охоплюють 10215 ОР і представляють 81 тип міжчастиномовних морфологічних омонімів $^{102}$. Решта моделей представляє омонімію всередині одного лексикограматичного класу ${ }^{103}$.

Як показав аналіз 81 типу міжчастиномовних морфологічних омонімів, 6 типів із них охоплюють 95 \% усіх омонімічних рядів. До них належать: AI, ДI, АД, ДТ, ІТ, АТ (табл. 20.1). Саме ці типи становлять ядро морфологічної омонімії у словниковому складі української мови. Всі вони представлені повнозначними частинами мови: змінними - іменником, ад'єктивом, дієсловом та незмінною прислівником. Заслуговує на увагу той факт, що при цьому мова використовує усі потенційно можливі комбінації цих класів.

Таблиця 20.1. Типи морфологічних омонімів, що утворюють ядро морфологічної омонімї

\begin{tabular}{|c|c|c|}
\hline Тип & Кількість омографів & Приклад \\
\hline АІ & 5682 & вартові, виборні \\
\hline ДІ & 2406 & коти, лови \\
\hline АД & 588 & бадьорим, білим \\
\hline ДТ & 389 & значимо, мислимо \\
\hline ІТ & 342 & візаві, ажур \\
\hline АТ & 272 & балакуче, захоплююче \\
\hline
\end{tabular}

Решта 75 типів морфологічних омонімів становлять периферію, обіймаючи лише 5 \% морфологічної омонімії у словниковому складі української мови.

Оцінка низькочастотних типів за їх наповнюваністю показала, що частину 3 них представлено обмеженими у вживанні лексемами та словоформами рідковживаними, застарілими, діалектними. До таких типів належать 17 двокомпонентних: AP (сьому, жадним компонент Р з позначкою 'рідко'), TS

102 Див. про це у роботі Шипнівська О. О. Кількісна та якісна характеристика типів морфологічних омонімів сучасної української мови. Актуальні проблеми української лінгвістики: теорія і практика: зб. наук. праць. Київ: видавничо-поліграфічний центр «Київський університет», 2005. С. 36-42. 
(покіль компонент Т у значенні «поки» 3 позначкою 'розмовне'), IН (двійко компонент Н з позначкою 'розмовне'), РТ (щзось компонент Т у значенні «чомусь» з позначкою 'розмовне'), TZ (отуm компонент Т з позначкою 'розмовне' ), IO (мені компонент I на позначення 'риби' 3 позначкою 'діалектне'), IZ (осе компонент Z 3 позначкою 'діалектне'), QД (дінь компонент Q 3 позначкою 'розмовне'), ТР (опроче компонент Р у значенні «крім» 3 позначкою 'діалектне'), QZ (ге компонент Z з позначкою 'розмовне'), IS (коби компонент S у значенні «якби» $з$ позначкою 'діалектне'), PZ (отсе компонент Z з позначкою 'рідко'), RH (ciм компонент R 3 позначкою ‘рідко’), QT (цуоб компонент Т у значенні «праворуч» 3 позначкою ‘розмовне'), ДР (при компонент Д у значенні «поперти» 3 позначкою 'розмовне'), ДR (сій компонент R з позначкою 'рідко'), PS (отим компонент S у значенні «тому» 3 позначкою 'розмовне') містять омографи, які можуть мати значення діалектної або рідковживаної словоформи.

Вісім трикомпонентних типів ITP (округ компонент $\mathrm{T} 3$ позначкою 'розмовне', компонент Р з позначкою 'рідко'), AIT (добряче компоненти I та А 3 позначкою 'розмовне'), IOR ( $y c i$ - компонент I у значенні «вухо» 3 позначкою 'розмовне'), QSZ (ба компонент Q з позначкою 'розмовне'), ДIT (осліп компонент Т у значенні «несвідомо» 3 позначкою 'рідко'), ДТР (подовш компонент Т у значенні «уздовж» з позначкою 'діалектне'; cycniль компонент Д наказовий спосіб дієслова 'суспілити' з позначкою 'рідко'), ДТR (всяк компонент R з позначкою 'розмовне'), ISZ (помісь компоненти S та Z у значенні «неначе» 3 позначкою 'діалектне') мають омоніми, які в словнику подаються з ремаркою діалектної чи рідковживаної лексики. Містить рідковживаний омограф й чотирикомпонентний тип IOTR (того компонент Т з позначкою 'розмовне').

Дванадцять типів 3 тих, що мають лише по одному ОР, також містять обмежену у вживанні лексику: QPZ (на компонент Z з позначкою 'розмовне'), OTRSZ (все компоненти T, S, Z з позначкою 'розмовне'), QIZ (ага компонент Z 3 позначкою 'розмовне'), QISZ (но компонент S з позначкою ‘розмовне'), QIT (цабе компонент I з позначкою 'розмовне'), QAI (гулі компонент I у значенні «щось веселе, з розвагами, танцями» має позначку 'розмовне'), ДS (наколи компонент $\mathrm{S}$ з позначкою 'діалектне'), ДSZ (хоч компонент Д з позначкою 'розмовне'), АТД (ревне компонент Т у значенні «наполегливо» з позначкою 'розмовне'), OTRSZ (усе компонент Т у значенні «завжди, скрізь, досі» 3 позначкою 'розмовне', $\mathrm{S}$ у значенні «все-таки» та компонент Z з позначкою 'розмовне'), IPSZ (помість компоненти S та Z у значенні «неначе» та компонент P nомість у значенні «замість» $з$ позначкою 'діалектне').

Аналіз типів омонімів 3 погляду на їхній кількісний компонентний склад показав, що довжина омонімічних ланцюжків кодів варіюється від двох до шести. Дані щодо розподілу міжчастиномовних омографів наведено в табл. 20.2. 
Таблиця 20.2. Співвідношення довжини омонімічного ланцюжка типів морфологічних омонімів та їхньої абсолютної частоти

\begin{tabular}{|l|l|}
\hline \multicolumn{1}{|c|}{ Довжина омонімічного ланцюжка } & \multicolumn{1}{c|}{ Абсолютна частота } \\
\hline Двосимвольні & 11904 \\
\hline Три символьні & 146 \\
\hline Чотири символьні & 9 \\
\hline п'ятисимвольні & 1 \\
\hline Шести символьні & 1 \\
\hline
\end{tabular}

\subsection{3. Дослідження морфологічної омонімії на матеріалі УНЛК}

Мовленнєвий аспект морфологічної омонімії досліджувався на матеріалі УНЛК як морфологічно анотованого корпусу.

Необхідною передумовою будь-якого лінгвістичного дослідження, що має на меті встановлення кількісних характеристик описуваного явища, $\epsilon$ представлення матеріалу дослідження репрезентативним корпусом. Під репрезентативністю корпусу, зазвичай, розуміють такий тип відображення проблемної області в корпусі, при якому останній відображає всі суттєві властивості аналізованого явища, релевантні для лінгвістичного дослідження, в певній пропорції, яка визначається частотою явища в проблемній області ${ }^{104}$. Принцип репрезентативності при проведенні дослідження забезпечувався: 1) обранням предметом дослідження текстів сучасної української мови трьох функціональних стилів - наукового, публіцистичного та художнього; 2) достатнім обсягом сукупної вибірки - на базі УНЛК було сформовано текстові вибірки обсягом 1000000 словоформ кожна. Як показав попередній аналіз, у вибірці 3000000 словоформ представлено 95,06 \% всіх типів морфологічних омонімів української мови.

У жанрово-тематичному плані сформований для проведення дослідження субкорпус наукової літератури представляв як суспільні, так і природничі науки: підручники та посібники 3 історії, економіки, історії філософії, культурології, права, соціології, економічної політики, автореферати з медицини, біології, геології, географії, хімії, екології, біофізики, математики. Нижньою хронологічною межею субкорпусу визначено 90-ті роки ХХ ст.

До субкорпусу текстів публіцистичного стилю увійшли публіцистичні матеріали різних жанрів переважно суспільно-політичної тематики з газет «День» та «Україна молода» за період 2001-2004 pp.

${ }^{104}$ Баранов Н. Проблемы репрезентативности корпуса данных (на примере политической метафоры). URL: http://www.dialog-21.ru.; Перебийніс B. І. Статистичні методи для лінгвістів: Навчальний посібник. Вінниця: Нова книга, 2001. С. 15-16.; Шимкова М. Репрезентативность корпуса как лингвистическая проблема. Прикладная лингвистика в поиске новых путей. Мат. междунар. конф. (Украина, Крым, Меганом, 27 июня - 2 июля 2005). С. 55. 
До субкорпусу текстів художнього стилю увійшли твори М. Стельмаха, Ю. Мушкетика, С. Гуцала, В. Шевчука, В. Дрозда, В. Земляка, І. Білика, В. Шкляра, В. Чемериса, В. Малика, які представляють українську літературу другої половини та кінця XX - початку XXI ст.

Встановлення в текстах омонімічних рядів, моделей та типів морфологічних омонімів, так само як аналіз словника словоформ, здійснювалося в програмний спосіб шляхом використання системи АМА. Після вилучення 3 текстів субкорпусів словоформ з кодами абревіатур, скорочень та власних назв, які не входять до граматичного словника та відсутні в словнику словоформ, обсяг вихідних одномільйонних вибірок зменшився: для текстів наукового стилю - до 979297 словоформ, публіцистичного - до 989 086, художнього - до 992558.

За результатами аналізу одержаних вибірок з погляду співвідношення в них однозначних і омонімічних одиниць було визначено, що в текстах наукового стилю морфологічно неоднозначні словоформи становлять 67,01 \% (656303 словоформи) від загальної кількості словоформ вибірки. Для публіцистичного стилю цей показник становить 60,13\% (618 017 словоформ), для художнього $55,11 \%$ (560 632 словоформ).

Розбіжність між відсотковими показниками морфологічних омонімів у досліджуваних стилістично диференційованих текстах визначалася за формулою обчислення коефіцієнту Стьюдента для попарного зіставлення кількісних показників лінгвістичного явища у різних за обсягом вибірках, наведеної в роботі В. І. Перебийніс ${ }^{105}$ :

$$
t=\frac{p_{1}-p_{2}}{\text { Sed }}
$$

де $t$ - коефіцієнт розбіжності, $p_{1}$ - відносна частота лінгвістичного явища (в \%) для першого масиву, $p_{2}$ - відносна частота лінгвістичного явища (в \%) для другого масиву. Sed обчислюється як:

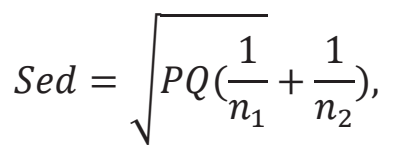

де $n_{1}$ - обсяг першої вибірки, на основі якої обчислювалися проценти, $n_{2}$ - обсяг другої вибірки. Символ $P$ означає середню для двох вибірок відносну частоту (\%), яка обчислюється за формулою:

$$
\begin{gathered}
P=\frac{p_{1} n_{1}+p_{2} n_{2}}{n_{1}+n_{2}}, \\
Q=100-\mathrm{P} .
\end{gathered}
$$

За таблицею критичних значень показника $t$, розбіжність між двома порівнюваними вибірками не визначається значущою при $\mathrm{t} \leq 1,96$.

${ }^{105}$ Перебийніс В. І. Статистичні методи для лінгвістів. Вінниця: Нова книга, 2001. C. $82-84$. 
Усі обчислені коефіцієнти свідчать про істотні розбіжності між показниками частоти вживання морфологічних омографів в науковому, публіцистичному i художньому стилях. Так, $t$ для вибірок наукового та публіцистичного стилів становить 2,00 , наукового та художнього - 1,98 , художнього та публіцистичного - 1,99 .

На наступному етапі аналізу для кожної із вибірок було визначено загальну кількість омонімічних рядів (ОР). Найбільша кількість ОР представлена в текстах публіцистичного стилю - 37774 . У текстах наукового стилю їх 32983 , художнього - 33639 .

Зіставлення одержаних показників за вищенаведеною формулою показало, що, як і в попередньому випадку, за показниками вживання в текстах омонімічних рядів досліджувані функціональні стилі істотно відрізняються. Так, $t$ для вибірок текстів наукового та публіцистичного стилів становить 2,05, наукового та художнього - 2,05, публіцистичного та художнього - 4,30.

За результатами порівняння одержаних показників щодо реалізації в мові омонімічних рядів із відповідними показниками, виведеними за словником словоформ, було встановлено, що тексти наукового стилю реалізують лише 5,4 \% від загальної кількості (610 612) омонімічних рядів, зафіксованих у СС, тексти публіцистичного стилю - 6,2 \%, тексти художнього стилю $-5,5 \%$.

Аналіз сукупностей ОР, виділених в аналізованих вибірках, 3 погляду представлення їх структурними моделями, показав, що найбільшу кількість зі списку визначених потенційних моделей омонімів української мови реалізують художні тексти (981 моделей), найменшу - наукові (752 моделей). Омонімічні ряди в публіцистичних текстах представлено 869 моделями.

\subsection{4. Міжчастиномовні морфологічні омоніми в українських текстах}

Як зазначалося, для розроблення алгоритмів автоматичного зняття морфологічної омонімії ключовою $є$ інформація про реалізовані в текстовому масиві типи міжчастиномовних омонімів та частоту їх вживання. Виділені в текстах типи морфологічних омонімів обумовлюють вибір конкретних текстових ситуацій, а за даними про частоту моделей морфологічних омонімів визначається ієрархія правил, покладених в основу алгоритму їх ідентифікації.

За результатами дослідження встановлено, що міжчастиномовні морфологічні омоніми найбільше представлені в художніх текстах, де їх частка становить 53,23\% (225 746 омонімів) відносно загальної кількості морфологічно неоднозначних словоформ. У публіцистичному стилі їх частка становить 41,21 \% (254 713 омонімів). Найменшу частку встановлено в текстах наукового стилю $34,39 \%(298678)$. 
Коефіцієнти розбіжності між показниками частоти вживання міжчастиномовних морфологічних омонімів, обчислені за наведеною в п. 20.1.2 формулою, виявилися i в цьому випадку істотними. При порівнянні виборок наукового та публіцистичного стилів $t$ дорівнює 1,99 , наукового та художнього 1,97, художнього та публіцистичного - 1,98.

Найбільшу кількість омонімічних рядів, представлених міжчастиномовними омонімами в досліджуваних вибірках, зафіксовано в текстах публіцистичного стилю - 2 355, у художніх текстах їх - 2 150, у наукових - 1880 . Загалом тексти сучасної української мови реалізують 58 \% (5 940 ОР) від загальної кількості ОР міжчастиномовних морфологічних омонімів. Визначені коефіцієнти розбіжності між цими показниками виявилися істотними для вибірок наукового та публіцистичного стилів - 2,23, наукового та художнього - 2,23. Проте розбіжність між цими показниками є незначною для вибірок публіцистичного та художнього стилів, де частка омонімічних рядів становить $0,38 \%$.

На основі отриманих списків ОР за тотожними омонімічними кодами було визначено моделі міжчастиномовних омонімів, що функціонують в українській мові. В аналізованих вибірках найбільший відсоток реалізації ММО від загальної кількості встановлених на момент дослідження в мові 820 моделей зафіксовано в текстах художнього стилю - 70,73 \% (580 моделей). Тексти публіцистичного стилю реалізують $62,07 \%$ міжчастиномовних омонімів (509 моделей), наукового - 52,92 \% (434 моделей).

За результатами порівняння текстів аналізованих стилів за частотою міжчастиномовних омонімів, кількістю ОР та кількістю моделей міжчастиномовних омонімів, встановлено, що найменші показники за частотою i за кількістю моделей має науковий стиль, найбільші - художній. Натомість тексти публіцистичного стилю переважають за кількістю ОР, що свідчить про їхнє лексичне різноманіття.

381 типу міжчастиномовних морфологічних омонімів української мови, виділених у словнику словоформ, у досліджуваних текстах наукового стилю зафіксовано 70 типів, публіцистичного - 75 типів, художнього - 77 типів. Отже, художній стиль реалізує максимальну кількість потенційно заданих мовою морфологічних омонімів, науковий, відповідно, мінімальну.

За результатами дослідження встановлено, що чотири типи міжчастиномовних омонімів не виявлено на вибірці в 3 млн словоформ. До них належать: дієслово / сполучник (ДS), ад'єктив / прислівник / дієслово (АТД), ад'єктив / прислівник / сполучник (ATS), іменник / прийменник / сполучник / частка (IPSZ). Як показує аналіз цих типів 3 позиції їх представлення конкретними омонімічними рядами, до них входять словоформи діалектних та розмовних лексем. Так, в типі ДS компонент $\mathrm{S}$ (сполучник) наколи з позначкою ‘діалектне', у АТД компонент Т (прислівник) ревне у значенні «наполегливо» 3 
позначкою 'розмовне', у AIS компонент S (сполучник) тале у значенні 'але' 'рідко' та кличний відмінок іменника тал у значенні «таловина» 3 позначкою 'рідко, 106 , у IPSZ компоненти S (сполучник) та Z (частка) помість у значенні «неначе» та $\mathrm{P}$ (прийменник) помість у значенні «замість» 3 позначкою 'діалектне'.

Решта 77 міжчастиномовних омонімів функціонують хоча б в одному зі стилів. Зокрема, зафіксовані лише у художньому стилі типи: ДТР (дієслово / прислівник / прийменник), QIT (вигук/ іменник/ прислівник). У кожному з омонімічних рядів цих типів хоча б один із компонентів має позначку 'розмовне', ‘діалектне' або ж 'рідко'. Тип ДТР представлений ОР суспіль, подовщ і здовж. У першому має позначку 'рідко’ дієслівна форма, у другому компоненти P (прийменник) та Т (прислівник) подовщ з позначкою 'діалектне', у другому Т (прислівник) та Р (прийменник) здовж $з$ позначкою 'розмовне'. У типі QIT компонент I (іменник) цабе має позначку 'розмовне'.

П'ять типів 3 омонімічними рядами, один або два компоненти яких представляють обмежену у вживанні лексику - застарілу, рідковживану або 3 розмовним забарвленням, зафіксовано лише в текстах публіцистичного та художнього стилів. Тип RS представлений омонімічними рядами отим та оттим. У першому з них обидва компоненти мають позначку 'розмовне', у другому обидва компоненти мають позначку 'рідко'. У типі QAI гулі компонент I (іменник) у значенні «щось веселе, 3 розвагами, танцями» має позначку 'розмовне', а компонент Q (вигук) також має ту саму позначку. Тип ДТR, представлений омонімічними рядами всяк, усяк, обидва компоненти яких мають позначку 'розмовне'. У типі ITZ гаразд компонент Z (частка) має позначку 'діалектне'. У типі QZ ге, ну компонент Z (частка) має позначку 'розмовне'.

70 типів морфологічних омонімів 3 множини потенційно можливих, зафіксованих в усіх вибірках, можна вважати регулярними, такими, що функціонують в текстах усіх стилів сучасної української мови. До них належать типи: AH, AZ, AI, ДІ, АД, ДТ, IT, AT, OR, АДІ, QI, TP, SZ, IR, IP, AR, ORH, IH, 3T, TZ, IO, IZ, QД, IHP, AIT, OH, TSZ, IOR, QДI, IS, RZ, TR, RH, QS, QT, ДР, TH, ДІТ, ДР, ДZ, ДIS, QP, ITSZ, IOTR, ISZ, ORZ, OTRZ, ORS, QPZ, QTZ, OTRSZ, QIZ, QISZ, OSZ, OZ, TRZ, TPZ, OS, ДІР, ДІтS, ДSZ, ДН, IOTRSZ, OTR, OTRS, ДО, ДOR, ITS, OTH, TS. Перелічені типи повинні обов'язково враховуватися при побудові алгоритмів автоматичного зняття омонімії.

${ }^{106}$ Форма кличного відмінка моделюється як теоретично можлива для всіх іменників в однині та множині. 


\subsection{5. Частота вживання TMO в текстах}

Основними параметрами опису функціонування 77 типів, зафіксованих у досліджуваних текстах, є: частота вживання типів морфологічних омонімів у тексті, представлення типів омонімічними рядами, кількісний компонентний склад ТМО, представлений омонімічним кодом. Подальший аналіз міжчастиномовних омонімів здійснювався на матеріалі об'єднаної вибірки текстів досліджуваних стилів. Через різну довжину вибірок було використано поняття середньої відносної частоти ${ }^{107}$. Середня відносна частота вживання конкретного типу міжчастиномовних омонімів $\left(\mathrm{P}_{\mathrm{c}}\right)$ у текстах кожного зі стилів обраховувалась як відношення суми його абсолютних частот у кожній із підвибірок до загального обсягу об'єднаної вибірки. Одержані в такий спосіб $\left(\mathrm{P}_{\mathrm{c}}\right)$ дані для зафіксованих за результатами дослідження ТМО наведено в табл. 20.3.

Записаний у таблиці ряд ТМО за низхідними показниками їхніх середніх відносних частот емпірично було розбито на три зони: високочастотну, зону середньої частоти та низькочастотну зону. До високочастотної зони увійшли типи, Р $\mathrm{P}_{\mathrm{c}}$ яких знаходяться у межах 1-5\%. До низькочастотної зони потрапили типи 3

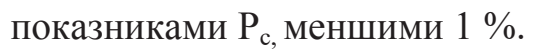

Як видно з таблиці, зону високої частоти утворюють дво- та трикомпонентні типи морфологічних омонімів, компонентами яких $\epsilon$ неповнозначні незмінні лексико-граматичні класи: QSZ (вигук/ сполучник/ частка), SZ (сполучник / частка), QPZ (вигук / прийменник / частка), QP (вигук / прийменник), неповнозначні лексико-граматичні класи 3 повнозначними: IP (іменник/ прийменник), OSZ (займенник-іменник/ сполучник/ частка) та повнозначні лексико-граматичні класи: ДІ (дієслово / іменник), OR (займенник іменник / займенник - прикметник), IO (іменник / займенник - іменник).

107 Перебийніс В. С. Статистичні методи для лінгвістів: навч. посібн. Вінниця: Нова Книга, 2001. С. 45. 
Таблиця 20.3. Середня відносна частота вживання ТМО у текстах

\begin{tabular}{|c|c|}
\hline тип & $\begin{array}{c}\text { Середня } \\
\text { відносна } \\
\text { частота }\end{array}$ \\
\hline QSZ & 13,83 \\
\hline SZ & 7,89 \\
\hline QPZ & 7,39 \\
\hline IP & 7,12 \\
\hline OR & 6,04 \\
\hline QP & 5,75 \\
\hline IO & 5,64 \\
\hline OSZ & 5,19 \\
\hline ДІ & 5,05 \\
\hline AI & 3,84 \\
\hline ORS & 3,64 \\
\hline TTSZ & 3,48 \\
\hline TPZ & 3,07 \\
\hline ORZ & 2,35 \\
\hline IT & 2,28 \\
\hline AT & 1,75 \\
\hline IOTR & 1,28 \\
\hline IOR & 1,19 \\
\hline ДР & 1,04 \\
\hline ТSZ & 1,02 \\
\hline ORH & 0,97 \\
\hline ТР & 0,94 \\
\hline OT & 0,84 \\
\hline ДITS & 0,80 \\
\hline & \\
\hline
\end{tabular}

\begin{tabular}{|c|c|}
\hline TZ & 0,70 \\
\hline OTRSZ & 0,70 \\
\hline Дt & 0,59 \\
\hline OZ & 0,38 \\
\hline АД & 0,37 \\
\hline IR & 0,34 \\
\hline OTRS & 0,35 \\
\hline TRZ & 0,34 \\
\hline ТН & 0,31 \\
\hline TS & 0,29 \\
\hline ДІS & 0,28 \\
\hline AДІ & 0,23 \\
\hline ДSZ & 0,23 \\
\hline ДОR & 0,21 \\
\hline IH & 0,19 \\
\hline QI & 0,18 \\
\hline QZ & 0,18 \\
\hline RН & 0,16 \\
\hline ДО & 0,16 \\
\hline IS & 0,15 \\
\hline ДН & 0,13 \\
\hline IZ & 0,13 \\
\hline OTRSZ & 0,12 \\
\hline OТRZ & 0,11 \\
\hline OS & 0,10 \\
\hline ДZ & 0,09 \\
\hline OTR & 0,08 \\
\hline & \\
\hline
\end{tabular}

\begin{tabular}{|c|c|}
\hline TR & 0,08 \\
\hline OТН & 0,06 \\
\hline ITP & 0,04 \\
\hline RZ & 0,04 \\
\hline AZ & 0,04 \\
\hline ITS & 0,04 \\
\hline ДІР & 0,04 \\
\hline QIZ & 0,03 \\
\hline QTZ & 0,03 \\
\hline ДR & 0,02 \\
\hline IHZ & 0,017 \\
\hline QISZ & 0,016 \\
\hline QT & 0,011 \\
\hline AIT & 0,0096 \\
\hline QДI & 0,0082 \\
\hline QД & 0,0062 \\
\hline ДІТ & 0,0059 \\
\hline ДТR & 0,0049 \\
\hline AR & 0,0027 \\
\hline RS & 0,0027 \\
\hline ISZ & 0,0025 \\
\hline ЗН & 0,0013 \\
\hline QIT & 0,0006 \\
\hline ДТР & 0,0005 \\
\hline QAI & 0,0005 \\
\hline AН & 0,0004 \\
\hline
\end{tabular}


Розподіл типів морфологічних омонімів за частотністю має об'єктивне пояснення. Так, до зони високої частоти увійшов тип морфологічних омонімів ДІ, компонентами якого $\epsilon$ найбільш інформативні частини мови, а тому найчастотніші у текстах - дієслово та іменник (у реєстрі граматичного словника іменники становлять $42 \%$, дієслова - $21 \%$ ). Також до цієї зони потрапили типи QSZ, SZ, QPZ, IP, IO, OR, QP, які, незважаючи на те, що охоплюють невелику кількість омонімічних рядів, представлені високочастотними лексемами або словоформами високочастотних слів, такими як: $i$, але, a (QSZ), $\breve{u}$, адже (SZ), на (QPZ), протягом, иляхом, перед, під, без, верх, кінець (IP), всі, інші, кожні, котрі $(\mathrm{OR}), o, y(\mathrm{QP})$. До цієї зони увійшов також тип IO (іменник / займенник-іменник), представлений IO вона (назва грошової одиниці; займенник-іменник), кому (іменник на позначення хворобливого стану; займенник-іменник), він (іменник жіночого роду на позначення струнного музичного інструменту; займенникіменник).

3-поміж двокомпонентних типів найчастотнішим є тип сполучник / частка (7,89\%), трикомпонентних - вигук/ сполучник/ частка $(13,83 \%)$, чотирикомпонентних - іменник / прислівник / сполучник / частка (3,48 \%).

До зони середньої частоти, крім дво- та трикомпонентних типів, увійшли чотирикомпонентні типи. 3-поміж двокомпонентних сюди потрапили ТМО, компоненти яких мають значення повнозначних частин мови: AI (ад'єктив/ іменник), IT (іменник/ прислівник), АТ (ад’єктив/ прислівник). 3-поміж трикомпонентних типів до цієї зони належать типи: TPZ (прислівник/ прийменник / частка), представлений одним OP за, TSZ (прислівник / сполучник / частка) з ОР тільки, ледве, тільки-но, щзойно. Серед чотирикомпонентних типів: ITSZ (іменник / прислівник / сполучник / частка), з 2 OP так, як, IOTR (іменник / займенник - іменник / прислівник / займенник - прикметник), представлений OP того (кличний відм. іменника тога), тому. Решта чотирикомпонентних типів увійшли до зони низької частоти.

До зони низької частоти увійшли п'ятикомпонентний та шестикомпонентний типи та більшість типів (22), які за словником словоформ мають лише по одному омонімічному ряду: коли (ДITS), все (3TRSZ), собі (OZ), тим (ОТRS), саме (TOZ), хоч (ДSZ), тих (ДОR), їм (ДО), три (ДН), усе (IOTRSZ), усього (OTRZ), чим (OS), всього (OTR), власне (AZ), доки (ITS), край (ДIP), ага (QIZ), гаразд (ITZ), но (QISZ), цуабе (QIT), гулі (QAI).

Сім типів, зафіксованих лише в художніх текстах, також належать до цієї зони: TS, ITZ, ДТR, RS, QIT, ДТР, QAI. 
За результатами дослідження встановлено залежність розподілу відносних частот типів морфологічних омонімів у текстах сучасної української мови від кількості компонентного складу, типів та частиномовної належності компонентів.

\subsection{6. Характеристика $T M O$ за наповнюваністю їхніх ОР}

Описані ТМО було розглянуто з погляду наповнюваності їх омонімічними рядами. Для цього кожному ТМО за показниками наповнюваності їх різними ОР (N) було приписано у низхідному порядку ранг ${ }^{108}$. Аналогічно ТМО було розподілено за рангами відповідно до показників відносної середньої частоти. Отримані дані показують, що частотні ТМО з повнозначними частинами мови мають найвищі ранги за кількістю ОР, проте у ряді ТМО, побудованому за відносною середньою частотою, вони поступаються місцем ТМО 3 неповнозначними незмінними частинами мови. За словником словоформ було встановлено, що шість двокомпонентних типів 3 повнозначними частинами мови - АІ, ДІ, АД, ДТ, ІТ, АТ - становлять $95 \%$ усіх ОР. Проаналізовані тексти засвідчили таку ж тенденцію: ці типи становлять 83,91 \%.

Для об'єктивної оцінки наявності залежності між показниками $P_{c}$ та $N$ на основі рангового розподілу було застосовано кореляційний аналіз. Для порівняння бралися ТМО, відносна середня частота яких є не меншою $1 \%$ (табл. 20.4). Обчислений за наведеною у роботі $\mathrm{B.C.} \mathrm{Перебийніс} \mathrm{схемою}$ коефіцієнт рангової кореляції надає підстави для висновку щодо відсутності кореляції між двома зазначеними параметрами ${ }^{109}$.

Отже, дослідження стилістично диференційованого субкорпусу текстів показало, що у текстах морфологічно неоднозначні словоформи становлять значну частку. Значення обчислених коефіцієнтів розбіжності між одержаними показниками частоти вживання морфологічних омонімів, частоти вживання міжчастиномовних морфологічних омонімів при попарному порівнянні вибірок кожного з функціональних стилів мови виявилися достатніми для розмежування стилів на формальних засадах.

Результати проведеного дослідження вказали на доцільність врахування якісно-кількісних характеристик типів морфологічних омографів при побудові алгоритмів автоматичного зняття морфологічної неоднозначності. Аналіз одержаних статистичних показників щодо кількості реалізації типів міжчастиномовних морфологічних омонімів у кожному субкорпусі переконливо засвідчив доцільність застосування ймовірнісного підходу при автоматичному знятті морфологічної неоднозначності. Статус пріоритетних отримують високочастотні типи. Типи, які зустрічаються лише в одному стилі, або ж типи,

108 Показник N визначався як відношення суми кількості ОР, що представляють ТМО в досліджуваних текстах трьох стилів до суми загальної кількості ОР у цих стилях.

${ }^{109}$ Перебийніс В. С. Статистичні методи для лінгвістів. Вінниця: Нова книга, 2002. 110 с. 
компоненти яких представляють обмежену у вживанні лексику, в алгоритмі контекстного аналізу посідають периферійне місце та потребують додаткової інформації про стилістичну належність тексту.

Таблиця 20.4. Ранговий розподіл частотних ТМО за відносною середньою частотою та наповнюваністю їх ОР

\begin{tabular}{|c|c|c|}
\hline ТМО & $\begin{array}{c}\text { Ранг за } \\
\text { відносною } \\
\text { середьюю } \\
\text { частотою }\end{array}$ & $\begin{array}{c}\text { Ранг за } \\
\text { кількістю } \\
\text { ОР }\end{array}$ \\
\hline QSZ & 1 & 11 \\
\hline SZ & 2 & 6 \\
\hline QPZ & 3 & 16,5 \\
\hline IP & 4 & 7 \\
\hline OR & 5 & 5 \\
\hline QP & 6 & 14,5 \\
\hline IO & 7 & 8 \\
\hline OSZ & 8 & 16,5 \\
\hline ДI & 9 & 1 \\
\hline AI & 10 & 16,5 \\
\hline ORS & 11 & 14,5 \\
\hline ITSZ & 12 & 16,5 \\
\hline TPZ & 13 & 14,5 \\
\hline ORZ & 14 & 3 \\
\hline IT & 15 & 4 \\
\hline AT & 16 & 14,5 \\
\hline OTR & 17 & 10 \\
\hline IOR & 18 & 12 \\
\hline ДP & 19 & 9 \\
\hline TSZ & 20 & \\
\hline & & \\
\hline
\end{tabular}

\subsection{7. Лінгвістична база контекстів морфологічних омонімів}

До бази морфологічних омонімів (МО) сучасної української мови, створеної на основі ЕГС та стилістично диференційованого корпусу текстів, було інтегровано лінгвістичну базу контекстів міжчастиномовних омонімів ${ }^{110}$. Остання у повному обсязі представляє контекстні оточення усіх моделей та типів морфологічних омонімів. Вихідним матеріалом для формування бази контекстів послугував УНЛК як морфологічно маркований корпус текстів різних стилів.

${ }^{110}$ Програмне забезпечення для створення лінгвістичної бази контекстів було розроблено в Українському мовно-інформаційному фонді НАН України С. В. Стариковим. 
Під контекстом омографа розуміємо його лексико-граматичне оточення в межах речення. Довжина контексту визначалася сімома одиницями (з урахуванням структурної розмітки тексту) ліворуч та праворуч. БД контекстів морфологічних омонімів складається 3 двох таблиць: Таблиці лексикограматичних контекстів міжчастиномовних морфологічних омонімів (табл. 20.5) та Таблиці діагностувальних контекстів (табл. 20.6).

Таблицю лексико-граматичних контекстів міжчастиномовних морфологічних омонімів структуровано за полями: «Омограф» (Поле 1), «Модель омографа» (Поле 10), «Лексико-граматичний контекст» (Поле 2). Компоненти граматичного контексту подано в окремих полях таблиці з урахуванням їхнього лінійного розташування щодо омографа. Ліве оточення записано в полях: «Лк_7» (Поле 3), «Лк_6» (Поле 4), «Лк_5» (Поле 5), «Лк_4» (Поле 6), «Лк_3» (Поле 7), «Лк_2» (Поле 8), «Лк_1» (Поле 9); праве -в полях: «Пк_1» (Поле 11), «Пк_2» (Поле 12), «Пк_3» (Поле 13), «Пк_4» (Поле 14), «Пк_5» (Поле 15), «Пк_6» (Поле 16), «Пк_7» (Поле 17). Поля таблиці заповнюються автоматично.

Нижче подано фрагмент таблиці лексико-граматичних контекстів міжчастиномовних морфологічних омонімів для моделі типу дієслово/іменник $<$ UBMHМКMN> (дієсл., недок. виду, наказ. сп., активн. ст., 2 особа одн. / ім., заг., чол. р., Н. в., мн. / ім., заг., чол. р., 3. в. мн. / ім., заг., чол. р., к. в. мн.). 


\begin{tabular}{|c|c|c|c|}
\hline LI әгош & $L^{-}$'М & घdЯdФd & \\
\hline 9I әгоц & $9^{-}$'у & $\forall \cap$ & \\
\hline \$I әгоц & $\varsigma^{-}$Ү्म & нWつW & \\
\hline †I әгоц & $t^{-}$Үу & $\Lambda \mathrm{yS}$ & \\
\hline EI әгоШ & $\varepsilon^{-}$мџ & ‘ & \\
\hline zІ әгоШ & $\tau^{-}$уц & $\mathrm{TW}$ & \\
\hline II әгоШ & I'-ущ & $\int \kappa$ & \\
\hline оI әгоШ & $\begin{array}{c}\text { ефеdıоно } \\
\text { qцәгој }\end{array}$ & NWYWHWЯก & NWXWHWGก \\
\hline 6 әгоџ & ${ }^{-}{ }^{-}$'L & & $\Lambda \mathrm{VSV}$ \\
\hline 8 әгоџ & $z^{-}$'्य & & $0 \mathrm{Ld} V \Lambda \mathrm{V}$ \\
\hline L әгоџ & $\varepsilon^{-}{ }^{-}$ & & $\mathrm{d} \lambda$ \\
\hline 9 әгоџ & $t^{-}{ }^{-}$ & & WW \\
\hline s әгоџ & $\varsigma^{-}{ }_{L}$ & & хуАуวу \\
\hline † әгоџ & $9^{-}$หมू & & VdGdつd \\
\hline ⿷ әгоџ & $L^{-}{ }^{-}{ }_{L}$ & & $0 \mathrm{~L}$ \\
\hline z әгоџ & 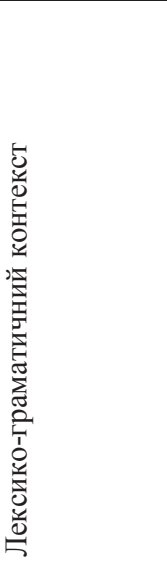 & 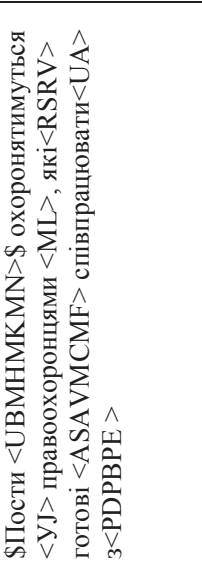 & 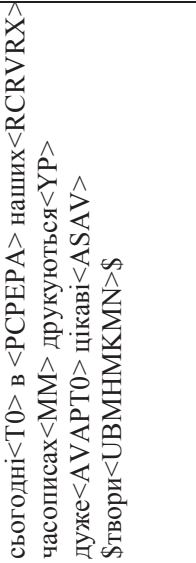 \\
\hline I әгоШ & 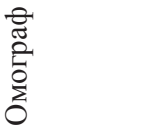 & $\begin{array}{l}\text { ज् } \\
\text { 品 }\end{array}$ & 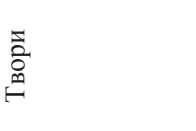 \\
\hline
\end{tabular}


Така форма представлення даних дозволяє за будь-яким параметром, визначеним виділеними полями, або за комбінацією параметрів автоматично формувати потрібні субкорпуси контекстів.

Для розроблення правил побудови алгоритму усунення морфологічної омонімії за результатами опрацювання таблиці лексико-граматичних контекстів міжчастиномовних морфологічних омонімів формувалася таблиця діагностувальних контекстів (ДК). Розмір контексту, достатнього для зняття омонімії, його позиція стосовно омографа (ліворуч, праворуч), конкретне граматичне значення ДК, а також актуальне граматичне значення омографа в цьому контексті визначалися в експертному режимі. Після чого заповнювалася табл. 20.6, яка складається 3 полів: «Модель омографа» (Поле 1), «Діагностувальний контекст» (Поле 2), «Актуальне граматичне значення омографа» (Поле 3), «Довжина ДК ліворуч» (Поле 4), «Довжина ДК «праворуч» (Поле 5), «Частота» (Поле 6). У полі «Діагностувальний контекст» подається граматичний контекст, довжина якого вважається достатньою для зняття омонімії. Довжина контексту у полях «Довжина ДК ліворуч» та «Довжина ДК праворуч» визначається кількістю текстових одиниць у межах ДК омографа $з$ урахуванням лівої та правої позиції. Актуальне граматичне значення, яке реалізується омографом у певному контексті, записується у полі «Актуальне граматичне значення омографа». Відносна частота діагностувального граматичного контексту в межах вибірки наводиться у полі «Частота».

У табл. 20.6 наведено фрагмент таблиці діагностувальних контекстів.

Табл. 20.6. Таблиця діагностувальних контекстів (фрагмент)

\begin{tabular}{|c|c|c|c|c|c|}
\hline Поле 1 & Поле 2 & Поле 3 & Поле 4 & Поле 5 & Поле 6 \\
\hline $\begin{array}{c}\text { Модель } \\
\text { омографа }\end{array}$ & $\begin{array}{c}\text { Діагностувальний } \\
\text { контекст }\end{array}$ & $\begin{array}{c}\text { Актуальне } \\
\text { граматичне } \\
\text { значення } \\
\text { омографа }\end{array}$ & $\begin{array}{c}\text { Довжина } \\
\text { ДК ліворуч }\end{array}$ & $\begin{array}{c}\text { Довжина } \\
\text { ДК } \\
\text { праворуч }\end{array}$ & $\begin{array}{c}\text { Частота } \\
(\%)\end{array}$ \\
\hline UBMHMKMN & $\begin{array}{c}<\text { ASAV }> \\
<\text { UBMHMKMN }>\end{array}$ & Іменник & 1 & 0 & 20,6 \\
\hline UBMHMKMN & $\begin{array}{c}<\mathrm{UA}> \\
<\mathrm{UBMHMKMN}>\end{array}$ & Іменник & 1 & 0 & 0,6 \\
\hline UBMHMKMN & $\begin{array}{c}<\text { UBMHMKMN }> \\
<\text { FHFCFFFBFKFN }>\end{array}$ & Іменник & 0 & 1 & 0,6 \\
\hline
\end{tabular}

За таким принципом будуються субкорпуси діагностувальних контекстів для кожної з моделей. На основі одержаних результатів було розроблено алгоритм контекстного аналізу як компонента програмного комплексу автоматичного морфологічного маркування УНЛК. 


\subsection{8. Дослідження функціонування українських прийменників у тексті на матеріалі УНЛК}

Дослідження прийменників $є$ багатоаспектним та проводиться, щонайменше, на трьох рівнях мови - морфологічному, синтаксичному i семантичному. Метою такого дослідження $\epsilon$ створення лінгвістичного забезпечення автоматичного опрацювання текстів, що враховує знання про функціонування прийменників в українських текстах.

Досягнення поставленої мети передбачає розв'язання низки завдань: 1) уточнення реєстру прийменників в УНЛК; 2) аналіз омонімії прийменника 3 іншими частинами мови; 3) визначення засад усунення омонімії прийменника 3 іншими частинами мови; 4) розроблення алгоритму розмежування складених прийменників від сполучень простого прийменника з повнозначним словом (за допомогою, з метою); 5) встановлення прийменникових зв'язків у тексті як окремого етапу автоматичного синтаксичного аналізу; 6) встановлення семантичних відношень між компонентами зони прийменникових зв'язків у системі автоматичного семантичного аналізу; 7) створення семантичного словника прийменникових конструкцій.

Дослідження функціонування прийменників, як і будь-яких інших одиниць мови, передбачає використання статистичних методів та методу контекстної діагностики. Відповідно, аналіз має проводитися на репрезентативному матеріалі 3 метою забезпечення належного рівня достовірності результатів. Таким матеріалом, власне, і слугував УНЛК.

Програмне забезпечення УНЛК дозволяе створювати спеціалізовані субкорпуси, орієнтовані на розв'язання широкого кола завдань. За допомогою спеціально розробленої у Фонді програми створені субкорпуси переводяться у формати БД з певною структурою, орієнтованою на проведення лінгвістичних досліджень. Лінгвістичні бази даних (ЛБД), які виконують функцію інструмента і матеріалу дослідження мовних фактів, структуровані за таким принципом: текстові сегменти (контексти), що містять конкретну мовну одиницю (прийменник), ставляться у відповідність визначеним наперед диференційним ознакам, за якими здійснюється аналіз. Структурування ЛБД за полями, що відповідають множині параметрів аналізу діагностувальних контекстів, та організація доступу до цих полів дозволяють автоматично класифікувати матеріал за кожним із параметрів та будь-якою їх комбінацією.

Відповідно до зазначених вище завдань у Фонді було створено три прийменникові лінгвістичні бази даних: ЛБД прийменникових сполучень претендентів на роль складеного прийменника (ЛБСП), ЛБД граматичних омографів $з$ прийменниковим компонентом (ЛБОП) та ЛБД зон прийменникових зв'язків (ЛБЗПЗ). 
Перша 3 них (ЛБСП), побудована на субкорпусі УНЛК обсягом 23 млн слововживань, орієнтована на попередньо укладений список прийменникових сполучень - претендентів на роль складеного прийменника (ПСП). ЛБСП представляє собою автоматично відібрані контексти для ПСП зі списку. Довжина контексту визначалася межами речення, в якому знаходиться конкретний ПСП. Структура бази містить поля «Претендент на роль складеного прийменника», «Морфологічно маркований контекст», «Функція прийменника». Обсяг ЛБСП 51025 речень $^{111}$.

Табл. 20.7. ЛБД претендентів на роль складених прийменників

(фрагмент)

\begin{tabular}{|c|c|c|}
\hline ПСП & Морфологічно маркований контекст & $\begin{array}{c}\text { Функція } \\
\text { прийменника }\end{array}$ \\
\hline у разі & $\begin{array}{l}\text { Наведено }<\text { VV }>\text { алгоритм }<\text { MAMD }>\text { та }<\text { SCRG }> \\
\text { повне }<\text { FGAAAD }>\text { описання }<\text { NANBNDNG }>\text { процедур }<\text { FI }> \\
\text { пошуку }<\text { MBMCMGMH }>\text { оптимального }<\text { ABADAN }> \\
\text { рішення }<\text { NANBNDNGNHNKNN }>[[\text { y }<\text { Q0PDPGPB }> \\
\text { разi }<\text { MF }>\text { ]] використання }<\text { NANBNDNG }> \\
\text { методики }<\text { FBFIFKFN }>\text { ігрового }<\text { ABADAN }> \\
\text { розташування }<\text { NANBNDNG }>\text { мережi }<\text { FBFCFFFHFKFN }> \\
\text { постів }<\text { MI }>\text { моніторингу }<\text { MBMCMGMH }> \\
\text { забруднення }<\text { NANBNDNGNHNKNN }>\text { атмосфери }<\text { FB }><\text { e }>\end{array}$ & Так \\
\hline у разі & 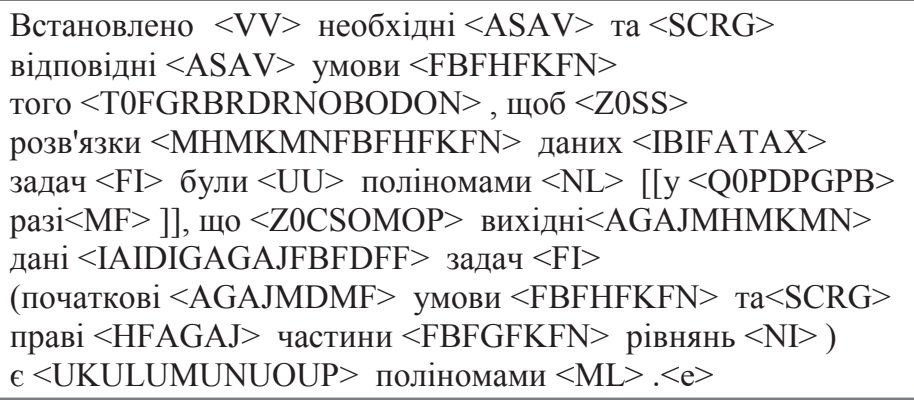 & $\mathrm{Hi}$ \\
\hline $\begin{array}{c}\text { у } \\
\text { випадку }\end{array}$ & $\begin{array}{l}\text { Наявність }<\text { FAFD }>\text { архіву }<\text { JBJC }>\text { дозволяє }<\text { UO }> \\
\text { відновити }<\text { VA }>\text { вихідні }<\text { AGAJMHMKMN }> \\
\text { файли }<\text { MHMKMN }>[[\text { [ }<\text { Q0PDPGPB }> \\
\text { випадку }<\text { MBMCMGMH }>\text { ]] ïx }<\text { OTOV }> \\
\text { пошкодження }<\text { NANBNDNGNHNKNN }>\text { або }<\text { SCZ0 }> \\
\text { втрати }<\text { FBFHFKFN }>\text {. }<>\end{array}$ & Так \\
\hline $\begin{array}{c}\text { у } \\
\text { випадку }\end{array}$ & 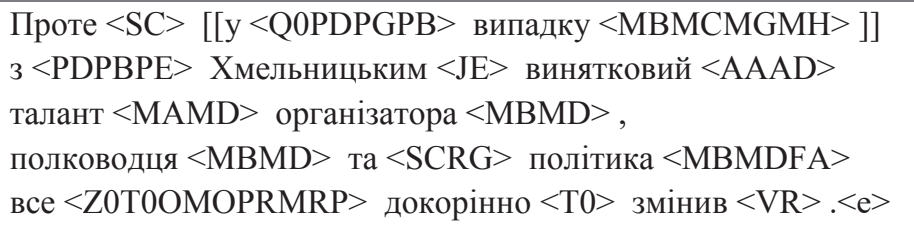 & $\mathrm{Hi}$ \\
\hline
\end{tabular}

${ }^{111}$ Бугаков О. В. Функціонування складених прийменників у тексті. Вісник Львівського університету. Серія філологічна. Львів: ЛНУ ім. І.Франка. 2004. Вип. 34. Ч. 1. С. 335. 
За аналогічним принципом будувалася ЛБОП. Список омографів (169 одиниць) був відібраний із загальної бази граматичних омографів української мови, описаної вище. Вихідними слугували морфологічно розмічені тексти наукового, художнього та публіцистичного стилів, кожний з яких представлений вибіркою в 1 млн слововживань. Структура бази містить поля 'Граматичний омограф', 'Морфологічно маркований контекст', 'Функція прийменника'. Загальний обсяг бази - 200123 контексти, з яких 59748 є реченнями з художніх текстів, 68911 - публіцистичних та 71464 - наукових. Відношення кількості омографів до кількості всіх прийменників у кожному з аналізованих стилів на прикладі аналізованих вибірок становить близько 57 \% (57,30 \% для художнього, $57,72 \%$ для публіцистичного, 57,62 \% для наукового) $)^{112}$.

Таблиця 20.8. Таблиця ЛБД граматичних омонімів з прийменниковим компонентом (фрагмент)

\begin{tabular}{|c|c|c|}
\hline $\begin{array}{c}\text { Граматичний } \\
\text { омограф }\end{array}$ & Морфологічно маркований контекст & $\begin{array}{c}\text { Функція } \\
\text { прийменника }\end{array}$ \\
\hline всередину & $\begin{array}{l}\text { Залежно }<\text { T0 }>\text { від }<\text { PBFI }> \\
\text { мети }<\text { MHMKMNFBFHFKFNUB }> \\
\text { дослідження }<\text { NANBNDNGNHNKNN }>\text { мазь }<\text { FAFD }> \\
\text { вводили }<\text { UU }>[[\text { всередину }<\text { PBT0 }>\text { ]] або }<\text { SCZ0 }> \\
\text { наносили }<\text { VUUU }>\text { місцево }<\text { T0 }>\text { на }<\text { PDPFQ0Z0 }> \\
\text { шкіру }<\text { FDMC }>\text {. }<\text { e }>\end{array}$ & $\mathrm{Hi}$ \\
\hline всередину & $\begin{array}{l}\text { В }<\text { PDPFPB }>\text { цьому }<\text { RCRFRORROOOR }> \\
\text { випадку }<\text { MBMCMGMH }>\text { створюється }<\text { YO }> \\
\text { дифузійний }<\text { AAAD }>\text { бар'єр }<\text { MAMD }>\text { для }<\text { PB }> \\
\text { проникнення }<\text { NANBNDNG }>\text { в }<\text { PDPFPB }> \\
\text { мембрану }<\text { FD }>\text { молекул }<\text { FI }>\text { глюкози }<\text { FB }>\text {, } \\
\text { y }<\text { QPDPGPB }>\text { той }<\text { FIRARDOAOD }>\text { час }<\text { MAMD }> \\
\text { як }<\text { ZOSST0MA }>\text { розчинений }<\text { CACD }>\text { кисень }<\text { MAMD }> \\
\text { має }<\text { UO }>\text { змогу }<\text { FD }>\text { вільно }<\text { T0 }>\text { проходити }<\text { VAUA }> \\
{[[\text { всередину }<\text { РBT0 }>\text { ] мембрани }<\text { FBFHFKFN }>\text {.e }>}\end{array}$ & Так \\
\hline шляхом & $\begin{array}{l}\text { Припинення }<\text { NANBNDNG }>\text { діяльності }<\text { FBFCFF }> \\
\text { Товариства }<\text { NBNHNKNN }>\text { здійснюється }<\text { YO }> \\
\text { [[шляхом }<\text { PBME }>\text { ] ] його }<\text { FGONOPOBODOZ }> \\
\text { реорганізації }<\text { FBFCFEFHFKFN }> \\
\text { (злиття }<\text { NANBNDNG }>\text {, } \\
\text { приєднання }<\text { NANBNDNGNHNKNN }>\text {, поділу }<\text { MBMC }> \\
\text {, виділення }<\text { NANBNDNGNHNKNN }>\text {, } \\
\text { перетворення }<\text { NANBNDNGNHNKNN }>\text { ) або }<\text { SCZ0 }> \\
\text { ліквідації }<\text { FBFCFRFHFKFN }>\text {. }<\text { e }>\end{array}$ & Так \\
\hline
\end{tabular}

${ }^{112}$ Бугаков О. В. Аналіз граматичної омонімії прийменників у мові й у тексті. Мовознавство. 2004. № 5-6. С. 90. 


\begin{tabular}{|c|l|c|}
\hline шляхом & $\begin{array}{l}\text { Встановлено }<\mathrm{VV}>\text {, що }<\text { Z0SSOMOP }> \\
\text { надходження }<\text { NANBNDNGNHNKNN }>\text { ПAP }<2 \mathrm{~A}> \\
\text { перкутанним }<\mathrm{AE}>[[\text { шляхом }<\text { PBME }>]] \text { не }<\text { Z0 }> \\
\text { перевищує }<\mathrm{UO}>1,5 \%<1 \mathrm{~A}>\text { кількості }<\text { FBFCFF }>, \\
\text { нанесеної }<\mathrm{CH}>\text { на }<\text { PDPFQ0Z0 }>\text { шкіру }<\text { FDMC }>\text {. }<>\end{array}$ & \\
\hline
\end{tabular}

Аналіз матеріалу цих ЛБД на основі виділених морфологічних кодів дозволив визначити низку ознак, за якими розроблялися алгоритми усунення омонімії прийменника 3 іншими частинами мови в тексті та розмежування складених прийменників від сполучень простого прийменника 3 повнозначним словом.

Результатом опрацювання ЛБД стало формування списку українських прийменників обсягом 230 одиниць ${ }^{113}$. На ньому було засновано лінгвістичну базу зон прийменникових зв’язків (ЛБЗПЗ), на якій проводилося дослідження функціонування прийменників в українських текстах 3 урахуванням їхніх синтаксичних та семантичних властивостей.

Зона прийменникових зв’язків (ЗПЗ) містить: прийменник (П), головне слово (ГС), яке керує прийменниково-іменниковою синтаксемою, та залежне слово (3С), що підпорядковується головному за допомогою прийменника).

Одержані результати використано при розробленні алгоритмічних правил ідентифікації зони прийменникових зв’язків у синтаксичній структурі речення як окремого модуля автоматичного синтаксичного аналізу (АСА) та алгоритму встановлення семантичних відношень між компонентами зони прийменникових зв’язків.

Вихідним текстовим матеріалом для формування ЛБЗПЗ послугували тексти публіцистичного стилю, відібрані з УНЛК, загальним обсягом 6 млн слововживань. Їхнім джерелом послугували газети «День», «Дзеркало тижня», «Хрещатик», «Україна молода», «Галицькі контракти», «Сучасність», «Київська Старовина» та журнали «Критика», «Світ дитячих бібліотек», «Сва». Вибір стилю зумовлений специфікою публіцистичної періодики охоплювати художню i наукову літературу, а також тим, що саме в текстах цього стилю найбільш широко, на думку спеціалістів 3 корпусної лінгвістики ${ }^{114}$, представлена нова лексика загального вживання.

Для кожного прийменника за допомогою спеціальної програми, розробленої у Фонді, було сформовано конкорданси, де межі контекстів визначалися початком

113 Фонетичні варіанти прийменників типу з/iз/зi/зo, в/y/si/yвi/ввi/во зведені в даному реєстрі до однієї одиниці.

${ }^{114}$ Див., наприклад, про це: Шимкова М. Репрезентативность корпуса как лингвистическая проблема. Прикладная лингвистика в поиске новых nymeŭ MegaLing'2005. Мат. междунар. конф. (Крым, Меганом, 27 июня - 2 июля 2005 г.). Симферополь: ТНУ им. В. И. Вернадского, 2005. С. 55. 
і кінцем речення, в якому зустрівся конкретний прийменник. Для прийменників 3 абсолютною частотою $\geq 50$ у вибірці обсягом 100 тис. слововживань конкорданси створювалися на основі цієї ж вибірки (22 прийменники: без, близько, в (y), від (од), для, до, з (із, зі, зо), за, крім (окрім), між (меж, межи), на, перед (переді, передо), niд (nidi, niдо), niд час, після, по, при, про, проти, серед, через, щүодо). Для прийменників із частотою, меншою 50, було зроблено декілька додаткових вибірок обсягом 1, 2, 3 і 6 млн слововживань. Список прийменників, зафіксованих у цих вибірках, склав 185 одиниць. Решта 45 прийменників у досліджуваних текстах не зустрілися i, відповідно, не були внесені в ЛБД. Аналіз цих прийменників потребує збільшення вибірки в кілька разів. Загальний обсяг одержаної бази - 20768 контекстів.

ЛБЗПЗ структурована за полями, що відповідають множині параметрів, попередньо визначених діагностувальними текстовими ознаками для алгоритмічного встановлення зон прийменникових зв'язків при АСА. Їх разом 3 описом вмісту наведено після табл. 20.9. 


\begin{tabular}{|c|c|c|c|c|c|}
\hline ияdвwәd & & & & & \\
\hline $\begin{array}{c}\text { вн } \\
\text { нәпонг!g }\end{array}$ & $\begin{array}{l}\text { әяоєеф-он } \\
\text { qॉедошพә L }\end{array}$ & әняицяәdи】 & І әняиоdКつ & $\begin{array}{c}\text { ән } \\
\text { яицяКА॰әәП }\end{array}$ & 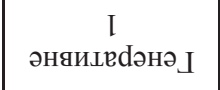 \\
\hline 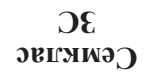 & әэподш & - & - & - & вяонецЈК \\
\hline ગE ТоУ & $<\mathrm{gN}>$ & $<\mathrm{gO}>$ & $<\mathrm{NY}>$ & $<\mathrm{gO}>$ & $<\forall \tau>$ \\
\hline $\mathcal{D E}$ & вннәжҢоден & ОІочн & оломь & әgəว & $\Lambda \mathrm{dH}$ \\
\hline 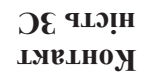 & Yв $_{L}$ & $\mathrm{ME}_{\mathrm{L}}$ & YE $_{L}$ & Yе $_{L}$ & $\mathrm{ME}_{\mathrm{L}}$ \\
\hline 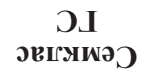 & в!̣ாоШ & $\mathrm{x} K \mathrm{~d}$ & $\mathrm{x} K \mathrm{~d}$ & эәподш & вннеяКوәдәш \\
\hline DI ГоY & $<\mathrm{L} M>$ & $<\mathrm{O} \cap>$ & $<\uparrow \Lambda>$ & $<\mathrm{CH}>$ & $<\mathrm{BH}>$ \\
\hline DI & $\begin{array}{c}\text { во } \\
\text { огиняошия }\end{array}$ & วГЙ (ән) & БОчLКНЈБL & Кяонা!̣ & 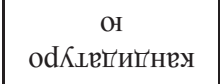 \\
\hline $\begin{array}{c}\text { PJ } \\
\text { qLग!̣LYRL } \\
\text {-ноУ } \\
\end{array}$ & צЕ $_{\mathrm{L}}$ & !H & !H & HE $_{L}$ & !H \\
\hline $\begin{array}{c}\text { ОЈ в!̣ா } \\
\text { ияошь⿻上 }\end{array}$ & !H & $\mathfrak{H E}_{\mathrm{L}}$ & HE $_{L}$ & !H & YE $_{L}$ \\
\hline $\begin{array}{c}\text { вуин } \\
\text { нәшйиdı } \\
\text { в!̣иєош } \\
\text { впाдәШ }\end{array}$ & !H & !H & !H & !H & !H \\
\hline $\begin{array}{c}\text { ЕШध } \\
\text { внижgо }\end{array}$ & $\varsigma$ & t & $\varepsilon$ & $\varepsilon$ & $\varepsilon$ \\
\hline 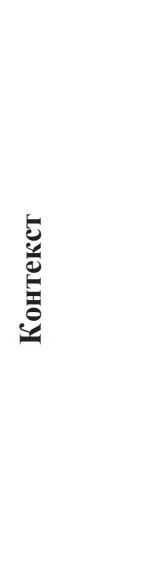 & 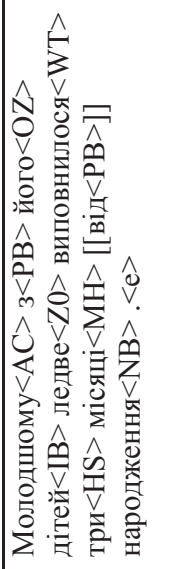 & 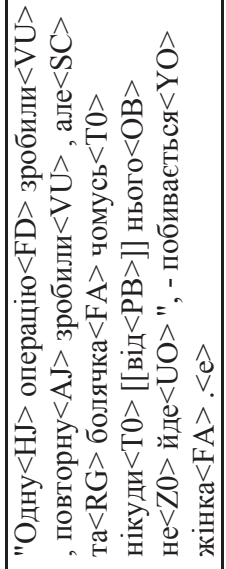 & 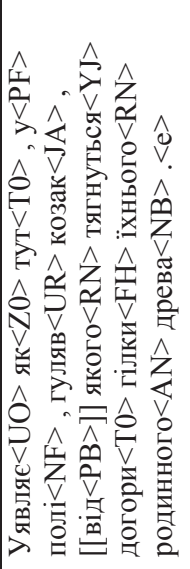 & 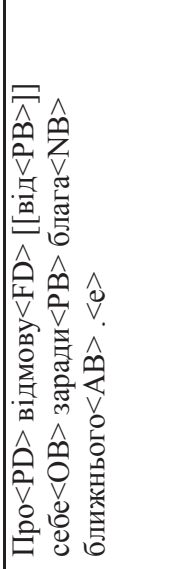 & 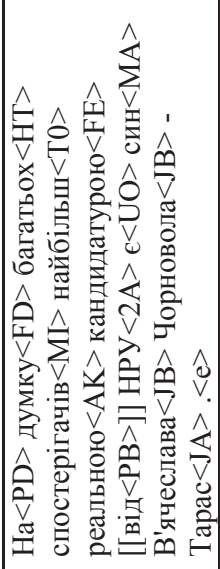 \\
\hline
\end{tabular}


Поля таблищі ЛБД зон прийменникових зв'язків:

\begin{tabular}{|l|l|}
\hline Назва поля & \multicolumn{1}{|c|}{ Вміст } \\
\hline Контекст & $\begin{array}{l}\text { Конкорданс морфологічно розмічених контекстів зі знятою омонімією } \\
\text { (заповнюєтья автоматично). }\end{array}$ \\
\hline Довжина 3П3 & Кількість слів у зоні прийменникових зв’язків у контексті. \\
\hline $\begin{array}{l}\text { Перша позиція } \\
\text { прийенника }\end{array}$ & Позначка «Так»або «Ні». \\
\hline Постпозиція ГС & Позиція головного слова щодо прийменника. \\
\hline Контактність ГC & $\begin{array}{l}\text { Вказівка про розташування головного слова відносно прийменника } \\
\text { (контактне або дистантне). }\end{array}$ \\
\hline ГС & Лексема, що є головним словом. \\
\hline Код ГС & $\begin{array}{l}\text { Граматичні характеристики головного слова у вигляді двосимвольних } \\
\text { кодів. }\end{array}$ \\
\hline Семклас ГС & Номер семантичного класу, до якого належить головне слово. \\
\hline Контактність 3С & $\begin{array}{l}\text { Відомості про контактне / дистантне розташування залежного слова } \\
\text { відносно прийменника }\end{array}$ \\
\hline ЗС & Лексема, що є залежним словом. \\
\hline Семклас 3С & Номер семантичного класу, до якого належить залежне слово. \\
\hline Відношення & $\begin{array}{l}\text { Семантичне відношення, яке виражає прийменник у кожній } \\
\text { досліджуваній зоні. }\end{array}$ \\
\hline Ремарки & $\begin{array}{l}\text { Інформація про однорідність головного чи залежного слів та } \\
\text { відсутність головного слова у зоні прийменникового зв’язку. }\end{array}$ \\
\hline
\end{tabular}

Всі поля таблиці, крім полів 'Контекст' та 'Ремарки' заповнювалися в автоматизованому режимі з використанням редактора таблиць MS Access та SQLзапитів.

Виділення атрибута 'Перша позиція прийменника' в окреме поле зумовлене тим, що ця ознака з великою вірогідністю визначає в реченні претендента на ГС і напрямок його пошуку.

Поле 'Контактність ГС' містить відомості про контактне або дистантне розташування головного слова відносно прийменника. Обидві ознаки $\epsilon$ важливими i враховуються в алгоритмічних правилах встановлення зв'язків прийменника при АCA. У випадку, коли в препозиції до прийменника в контактному розташуванні знаходиться прикметник або дієслово (а також дієприкметник, дієприслівник і форми на -но, -то), це слово однозначно отримує статус головного слова прийменника.

За інформацією поля 'ГС', вмістом якого є лексема - головне слово, встановлювалися регулярні зв'язки прийменника 3 ним. Для кожного прийменника визначалися набори граматичних класів, які можуть виступати у функції його головного слова, а також проводилася статистика щодо пріоритетності їхнього вживання.

Інформація стосовно семантичного класу головного слова у полі 'Семклас ГC' допомагає встановлювати зону прийменникового зв’язку у разі недостатності наявних граматичних і позиційних ознак. 
Поля 9-12 стосуються характеристик залежного слова. У полі 'Граматичні ознаки 3С' подано граматичні характеристики ЗС у вигляді двосимвольних кодів. Для кожного прийменника визначалися граматичні класи 3 вказівкою конкретних граматичних значень (підкласів), які можуть виступати у функції його залежного слова, і проводилася статистика щодо пріоритетності їхнього вживання. Інформація цього типу допомагала при визначенні головного слова.

\subsection{9. Дослідження функціонування прийменників на морфологічному рівні}

Серед проблем морфологічного аналізу та маркування корпусу текстів найбільш складними є проблема граматичної омонімії та проблема ідентифікації складених текстових одиниць - таких, що складаються з графемно різних слів (еквіваленти слова, складені прийменники).

Розроблення формальних засад усунення міжчастиномовної граматичної омонімії прийменників та розмежування складених прийменників та лексичних конструкцій типу прийменник + повнозначне слово потребувало проведення попереднього аналізу функціонування прийменників у тексті на матеріалі створених ЛБД. Використання ЛБД дозволило уточнити лексичний склад прийменників, який постійно поповнюється внаслідок релятивації (переходу повнозначних частин мови в прийменник) та через утворення складених прийменників.

\subsubsection{1. Усунення міжчастиномовної омонімії прийменників}

Як зазначалося вище, ефективність роботи систем автоматичного опрацювання текстів (АОТ) залежить від розв'язання проблеми зняття граматичної омонімії, що виникає при автоматичному морфологічному аналізі (АМА) природномовного тексту як ланцюга окремих словоформ ${ }^{115}$. Насамперед, це стосується систем машинного перекладу і систем індексування текстів. При машинному перекладі неправильно визначений граматичний клас словоформи спричиняє помилки на етапі визначення синтаксичної структури речення, що знижує якість перекладу. Нерозпізнані граматичні омоніми збільшують кількість синтаксичних омонімів (зауважимо, що останні існують у тексті й при однозначному визначенні граматичних характеристик словоформ), тим самим збільшуючи кількість варіантів перекладу. При автоматизованому індексуванні

115 За даними, одержаними в результаті аналізу роботи алгоритму AMA на матеріалі УНЛК, частота вживання омографів у тексті становить близько 70 \% від загальної кількості слововживань у ньому. 
нерозпізнані омографи (омонімічні словоформи) збільшують обсяг «ручної» роботи при постредагуванні.

Розв'язання проблеми міжчастиномовної граматичної омонімії прийменників має велике значення для автоматичного морфологічного аналізу, оскільки граматичні омоніми становлять близько 15 \% від усіх омонімів тексту ${ }^{116}$.

У Фонді на основі українських словників ${ }^{117}$, сучасних українських граматик $^{118}$ та результатів досліджень прийменника ${ }^{119}$ було сформовано список зі 142 омографів, що послугував основою ЛБД граматичних омографів із прийменниковим компонентом.

Через те, що процедура визначення граматичних значень омонімічних словоформ, передбачувана розробленим у Фонді АМА, спирається лише на графемну структуру словоформи, граматична багатозначність відображається як ланцюжок граматичних класів або граматичних значень у межах одного класу. Йдеться про повну омонімію: зверху - прислівник / прийменник; часткову омонімію: повз - прийменник / дієслівна форма та омоформію ${ }^{120}:$ моделі - іменник жіночого роду родового однини / давального однини / місцевого однини / називного множини / знахідного множини) Після зняття граматичної неоднозначності словоформи визначається те граматичне значення, яке вона має в конкретній мовленнєвій ситуації.

У розробленій в Фонді системі АМА інструментом усунення граматичної омонімії обрано контекстний аналіз ${ }^{121}$. Діагностувальні контексти виводилися 3

${ }^{116}$ Бугаков О. В. Аналіз граматичної омонімії прийменників у мові й у тексті. Мовознавство. 2004. № 5-6. С. 87-98.

${ }^{117}$ Словник української мови в 11 томах. Київ: Наукова думка, 1970-1980; Словник синонімів української мови в 2 томах. Київ: Наукова думка, 2001; Демська О. М., Кульчицький І. М. Словник омонімів української мови. Львів: Фенікс, 1996. 224 с.

${ }^{118}$ Сучасна українська літературна мова: Морфологія / за заг. ред. І. К. Білодіда. Київ: Наукова думка, 1969. 584 с.; Сучасна українська літературна мова: Синтаксис / за заг. ред. І. К. Білодіда. Київ: Наукова думка, 1972. 516 с.; Сучасна українська літературна мова / за ред. М. Я. Плющ. Київ: Вища школа, 2001. 432 с.

119 Див., наприклад: Вихованець І. Р. Прийменникова система української мови. Київ: Наукова думка, 1980. 286 с.; Загнитко А. П. Предлог в морфологическом пространстве украинского языка (синхронно-контрастивные наблюдения). Вестник московского университета. Сер. 9. Филология. № 3, 2003. С. 92-106; Іваненко 3. І. Система прийменникових конструкцій адвербіального значення. Київ - Одеса: Вища школа, 1981. 143 с.; Колодяжний А. С. Прийменник: Матеріали до лекцій з курсу сучасної української літературної мови. Харків: Вид-во Харків. ун-ту, 1960. 165 с.; Кучеренко І. К. Лексичне значення прийменника. Мовознавство. № 3, 1973. С. 12-23.

${ }^{120}$ Виноградов В. В. Об омонимии и смежных явлениях. Исследования по русской грамматике. Москва: Наука, 1975. С. 295-312.

${ }^{121}$ Колшанский Г. В. Контекстная семантика. Москва: Наука, 1980. 150 с.; Кочерган М. П. Слово і контекст: Лексична сполучуваність і значення слова. Львів: Вища школа, 1980. 184 с.; Маслов Ю. С. Омонимы в словарях и омонимия в языке (к постановке вопроса). Bonpocbl теории и истории языка. Ленинград: Изд-во Ленингр. ун-та, 1963. С. 198-202; Потебня А. А. Из записок по русской грамматике. Т. 1-2. Москва: Учпедгиз, 1958. 
лінійних ланцюжків, що оточують омонімічний прийменник в реченні. Контекстний аналіз експлікує зв'язок граматичних і семантичних параметрів лексичних одиниць та систем синтагматичних та парадигматичних відношень.

Система АМА розроблялася з урахуванням відомої тези 3. С. Харріса про те, що будь-які два елементи, які мають різні значення, так чи інакше відрізняються і стосовно дистрибуції ${ }^{122}$, тобто зустрічаються в двох різних наборах контекстів. Отже, діагностувальними вважаються синтагматичні контексти, які повторюються для одного елемента омонімічного ряду, але в яких ніколи не фігурують інші елементи цього омонімічного ряду. Ці контексти $\epsilon$ відображенням позиційної, граматичної i, в окремих випадках, лексичної сполучуваності конкретного граматичного класу певного омографа.

Крім того, дослідження функціонування прийменникових омографів 3 урахуванням актуалізації їхніх конкретних граматичних значень у текстах різних стилів сучасної української літературної мови показало, що при автоматичному морфологічному аналізі стиль аналізованого тексту виступає диференційною ознакою при усуненні омонімії.

Встановлення граматичних діагностувальних контекстів базувалося на результатах морфологічного маркування (тобто, в кодах граматичних класів i підкласів) словоформ аналізованого текстового масиву. Також за результатами дослідження функціонування омографів було встановлено, що розділові знаки мають таку саму діагностувальну здатність для розмежування багатозначності, як і слова. Тому при індексуванні речення розділовим знакам також приписується порядковий номер у реченні.

Алгоритм зняття омонімії являє собою ієрархію правил, в яких формально зафіксовано засади (текстові умови) визначення граматичного значення омонімічної словоформи. Правила об’єднуються в ситуації відповідно до граматичного статусу омографа та презентують дистрибутивні властивості граматичних класів - компонентів омонімічного ланцюжка щодо їхньої синтагматичної сполучуваності у лінійній послідовності словоформ в українському реченні. Основними типами інформації, яка при цьому використовується, $\epsilon$ : 1) морфологічна (морфологічні характеристики аналізованого слова, а також слів 3 його лівого та/або правого контекстів); 2) синтаксична (валентні особливості слів із оточення прийменника); 3) структурно-синтаксична (позиційні характеристики слова-омографа); 4) лексична (будь-яка інша інформація стосовно омоніма або його контекстного оточення).

Перевірка починається з більш загальних правил - граматичних, причому спочатку перевіряється лівий контекст, потім - правий. Зона перевірки контексту

${ }^{122}$ Хэррис 3. С. Метод в структуральной лингвистике // Звегинцев В. А. История языкознания XIX-XX веков в очерках и извлечениях. Ч. 2. Москва: Просвещение, 1965. С. 209-227. 
дорівнює дев'яти словоформам - три ліворуч і п’ять праворуч.

Діагностувальні контексти можуть бути спільними для всіх омографів, або такими, що визначаються диференційовано, лише для омографів певного типу. Наприклад, до всіх омографів застосовується правило щодо неможливості вживання двох прийменників поспіль в правильно побудованому тексті. Тобто, у випадку, коли у пре- або постпозиції до досліджуваного омографа зустрічається прийменник, програма вилучає з омонімічного ланцюжка код прийменника.

Для всіх омографів (за винятком омографа ради та групи омографів «прийменник, який керує залежною формою у давальному відмінку / прислівник» - вслід / услід; навздогін / наздогін, навперейми; назустріч / навстріч, наперекір, напереріз), спільним є правило, за яким з омонімічного ланцюжка вилучається код прийменника в разі наявності в правому діагностувальному контексті омографа розділових знаків - крапки, двокрапки, крапки 3 комою, дефісу, знаків питання та оклику. Такі омографи вимагають додаткової перевірки лівого контексту на наявність у ньому іменної форми в родовому відмінку (для ради) або в давальному (для вслід/ услід, навздогін/ наздогін, навперейми, назустріч / навстріч, наперекір, напереріз).

Продемонструємо роботу алгоритму розпізнавання, орієнтованого на конкретні групи, на прикладі групи омографів «прийменник, який керує залежною формою у родовому відмінку / прислівник», до складу якої належать 67 омографів, що становлять $56,8 \%$ від загального списку омографів 3 прийменниковим компонентом. Зона перевірки контексту (оточення) для зазначених омографів охоплювала п'ять елементів контексту - сам омограф, одне слово ліворуч (перед) і три слова праворуч (після).

Крім вищенаведених загальних правил, які вимагають перевірки як лівого, так і правого контекстів, є правила, що передбачають перевірку лише правого контексту (у т.ч. правила, пов'язані зі вживанням в постпозиції до прийменника залежної іменної форми в родовому відмінку):

1. Дієслово (в тому числі дієприслівник), а також іменник, займенник, прикметник, дієприкметник або числівник у будь-якому відмінку, крім родового, переводять омограф у прислівник;

2. Іменник, займенник, прикметник, дієприкметник або числівник у родовому відмінку, а також абревіатури і скорочення переводять омограф у прийменник;

3. Цифра (арабська чи римська) або сполучення символів $\{\$+-\}$ з наступною цифрою переводять досліджуваний омограф у прийменник;

4. Прислівник / частка із наступним пунктуаційним знаком або дієсловом, прислівником, сполучником переводить омограф у прислівник;

5. Прислівник із наступним прийменником, займенником, іменником, a також прикметником або дієприкметником у будь-якому відмінку, крім родового, переводить омограф у прислівник; 
6. Прислівник із наступним прикметником або дієприкметником, числівником у родовому відмінку і цифрою переводять омограф у прийменник;

7. Прислівник із наступною часткою, після якої стоїть прикметник у родовому відмінку, переводить омограф у прийменник;

8. Прислівник із наступною часткою, після якої стоїть будь-яка інша частина мови, переводить омограф у прислівник;

9. Частка із наступним іменником, займенником, прикметником, дієприкметником або числівником у будь-якому відмінку, крім родового, переводить омограф у прислівник;

10. Частка із наступним іменником, займенником, прикметником, дієприкметником або числівником у родовому відмінку, а також цифрою переводить омограф у прийменник.

Наступні правила стосуються випадку, коли в постпозиції до омографа знаходиться кома або сурядний сполучник.

11. Кома передбачає перевірку наступного слова. Якщо наступне слово (словосполучення) не є вставним, аналізатор переводить омограф у прислівник. У випадку ідентифікації слова (словосполучення) як вставного і вживання коми після нього аналізується наступне слово. Якщо це іменник, займенник, прикметник, дієприкметник або числівник у родовому відмінку, омограф переводиться в прийменник, в усіх інших випадках - у прислівник.

12. Сполучник сурядності з наступним прийменником переводять омограф у прийменник. Будь-яка інша частина мови після сполучника переводить омограф у прислівник.

Останню групу утворюють правила, за якими перевіряється лексичний контекст:

1. Числівник один / одне + одного в контактній позиції в правому контексті переводить омограф у прийменник;

2. Частка ні/ ані/ ma займенники нікого/нічого/ніякого в контактній позиції в правому контексті переводять омограф у прислівник.

Розроблений у Фонді АМА було протестовано на текстах публіцистичного стилю, що не ввійшли до ЛБД, на якій визначалися діагностувальні контексти. Аналіз результатів показав достатню діагностувальну здатність запропонованого методу розмежування граматичної омонімії ${ }^{123}$.

${ }^{123}$ Бугаков О. В. Усунення граматичної омонімії прийменників в українському тексті. Мовні і концептуальні картини світу: зб.наук. пр. Вип. 11. Кн. 1. Київ: Видавничий Дім Дмитра Бураго, 2004. С. 50-53. 


\subsubsection{2. Ідентиффікування складених прийменників у тексті}

Прийнятий в УНЛК ієрархічний порядок маркування текстів, коли кожен наступний етап маркування спирається на теги попереднього, зумовив необхідність ідентифікування на морфологічному рівні складених лексичних одиниць. Йдеться про зведення кількох графемно різних слів до одного лексичного слова - так званого еквівалента слова, що являє собою «зв'язану сполуку, яка характеризуються стійкістю, єдністю значення, переважно постійною, незмінною формою» ${ }^{124}$ (у разі коли, не в міру, лише б). Кількість компонентів у таких сполученнях може коливатися від 2 до 5: згідно з; з огляду на mе, щзо. Значення еквівалента слова формується інакше, ніж у слова: не власне в процесі членування навколишньої дійсності, а на підгрунті вже утворених у результаті пізнавальної діяльності мовних структур. Тому воно відрізняється від семантики слова більшим ступенем абстрактності та складності ${ }^{125}$.

Дослідження зазначених конструкцій зумовлене практичними потребами. При послівному морфологічному маркуванні корпусу кожен з компонентів таких конструкцій отримує свій власний код, що на синтаксичному і семантичному етапах аналізу тексту призводить до неправильної інтерпретації відношень між членами речення. Тому дослідники виділяють ідентифікування еквівалентів слова в окремий етап морфологічного аналізу ${ }^{126}$, що дозволяє усувати синтаксичну неоднозначність. ${ }^{127}$ Функціональна синтаксична і лексична єдність складених прийменників (СП) робить їх однією синтаксичною одиницею, що бере участь у керуванні залежною іменною формою. Відмінок залежного слова визначається

${ }^{124}$ Рогожникова Р. П. Словарь эквивалентов слова: наречные, служебные, модальные единства. Москва: Русский язык, 1991. С. 4.

125 Лучик А. А. Російсько-український та українсько-російський словник еквівалентів слова. Київ: Довіра, 2003. С. 19.

126 Див. про це: Ляшевская О. Н., Плунгян В. А., Сичинаева Д. В. О морфологическом стандарте Корпуса современного русского языка // НТИ. Сер. 2. № 6, 2005. С. 2-9; Копотев М. В. Неоднозначность и пути ее разрешения в хельсинском аннотированном корпусе «ХАНКО». «Корпусная лингвистика - 2004». Тр. междунар. конф. С.-Петербург: Изд-во С.Петерб. ун-та, 2004. С. 165-175; Мустайоки А., Копотев М. В. К вопросу о статусе эквивалентов слова типа потому что, в зависимости от, к сожалению/ Вопросы языкознания. № 3, 2004. С. 88-107.

127 Див. про це: Иорданская Л. Н. Автоматический синтаксический анализ. Т. 2. Межсегментный синтаксический анализ. Новосибирск: Наука, 1967. 290 с.; Копотев М. В. Неоднозначность и пути ее разрешения в хельсинском аннотированном корпусе «ХАНКО». Тр. междунар. конф. «Корпусная лингвистика - 2004». С.-Петербург: изд-во С.-Петерб. ун-та, 2004. С. 165-175; Мельчук И. А. Автоматический синтаксический анализ. Т. 1. Общие принципы. Внутрисегментный синтаксический анализ. Новосибирск: ред.-издат. отдел Сибир. отделения АН СССР, 1964. 356 с.; Синтаксический анализ научного текста на ЭВМ / под ред. Т. А. Грязнухиной. Киев: Наукова думка, 1999. 272 с. 
всією аналітичною конструкцією, а не валентностями iii прийменникового компонента. $^{128}$

Ідентифікування складених прийменників уточнює результат етапу АМА щодо зняття омонімії в ланцюжку іменних форм у постпозиції до складеного прийменника. Продемонструємо це на прикладі аналізу фрагмента речення: ...здійснено $<\mathrm{VV}>\quad$ з $<<\mathrm{PE}>\quad$ допомогою $<\mathrm{FE}>\quad$ модел $i<\mathrm{FBFCFFFHFKFN}>$... (результат роботи першого етапу АMA). Після другого етапу АМА (етапу зняття омоніміі) одержуємо: здійснено $<\mathrm{VV}>\quad$ о $a<\mathrm{PE}>\quad$ допомогою $<\mathrm{FE}>$ моделі $<\mathrm{FBFCFK}>$. Надання сполученню за допомогою статусу складеного прийменника автоматично викреслює 3 омонімічного ланцюжка словоформи моделі всі коди, крім одного - <FB $>$ (родовий відмінок однини), оскільки прийменник за допомогою передбачає саме його.

Ідентифікування еквівалентів слова при морфологічному аналізі відбувається аналогічно ідентифікуванню граматичних омографів.

Еквіваленти слова поділяють на класи залежно від того, функцію якої частини мови вони виконують: еквіваленти прислівників, простих і складених прийменників, сполучників, часток, вигуків, займенників, категорій стану (предикатів) ${ }^{129}$. Подальший виклад стосується лише складених прийменників (СП).

У прийменникових сполученнях, що одержують статус прийменника, повнозначні слова змінюють своє категоріальне значення внаслідок розвитку незвичних смислових і синтаксичних зв'язків 3 іншими словами в реченні ${ }^{130}$.

На етапах синтаксичного і семантичного маркування усім прийменникам приписується семантичне відношення, виразником якого є конкретний СП. Так, прийменникове сполучення за допомогою у функції прийменника вимагає в постпозиції іменної форми в родовому відмінку і в тексті виражає медіативні відношення. Тобто із потенційних можливостей прийменника за брати участь у керуванні знахідним, родовим, орудним відмінками вибирається родовий відмінок залежної форми, а серед переліку типів відношень, які цей прийменник можуть виражати в тексті (просторові, часові, причинні, способу дії, мети, кількісні, об'єктні), - медіативне відношення, що входить до обставинних способу дії.

За даними попереднього дослідження, проведеного на текстах обсягом 100 тис. слововживань, частота вживання складених прийменників серед усіх прийменникових вживань становить $3,2 \%{ }^{131}$.

${ }^{128}$ Бугаков О. В. Функціонування складених прийменників у тексті. Вісник Львівського університету. Серія філологічна. Вип. 34. Ч. 1. Львів: ЛНУ ім. І. Франка, 2004. С. 333-339.

${ }^{129}$ Мустайоки А., Копотев М. В. К вопросу о статусе эквивалентов слова типа потому что, в зависимости от, к сожалению. Вопросы языкознания. № 3, 2004. С. 89.

${ }^{130}$ Черкасова Е. Т. Переход полнозначных слов в предлоги. Москва: Наука, 1967. С. 19.

${ }^{131}$ Бугаков О. В. Функціонування складених прийменників у тексті. Вісник Львівського університету. Серія філологічна. Вип. 34. Ч. 1. Львів: ЛНУ ім. І. Франка, 2004. С. 333-339. 
Об’єктом аналізу виступили 144 прийменникових сполучення, визнані складеними прийменниками в сучасних українських граматиках та наукових дослідженнях, представлених у працях I. Р. Вихованця ${ }^{132}$, А. С. Колодяжного ${ }^{133}$ та А. А. Лучик ${ }^{134}$ (без урахування варіантів в / у межах, в / у напрямі / напрямку та ін.).

За компонентним складом складені прийменники зводяться до чотирьох типів: 1) простий прийменник + іменник у непрямому відмінку (PrepN: з метою, за допомогою); 2) простий прийменник + іменник у непрямому відмінку + простий

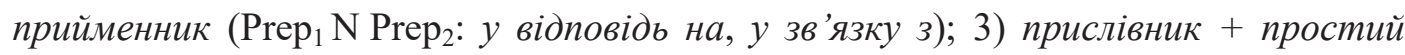
прийменник (AdvPrep: разом з, залежно від); 4) складені прийменники (незважаючи на; відповідно до; за винятком; згідно з).

Конструкції, що не відповідають наведеним структурним формулам, до списку прийменникових сполучень - претендентів на роль складених прийменників не увійшли. Тобто поза межами нашого дослідження лишилися сполучення: частка + прийменник (аж до, не без), прийменник + займенник (через те (це), при всьому (всій, всіх)), частка + дісприслівник (не враховуючи), частка + дієприслівник + прийменник (не кажучи про), зафіксовані у словнику еквівалентів слова $^{135}$.

Визначення ознак, за якими в тексті розрізняються складені прийменники від сполучень слів, здійснювалося на основі згаданої ЛБД прийменникових сполучень - претендентів на роль складених прийменників. Одержані конкорданси було розглянуто 3 погляду функціонального навантаження потенційних складених прийменників у синтаксичній структурі речення щодо виконання ними функцій прийменника. Аналіз здійснювався за диференційними ознаками, визначеними українськими й зарубіжними мовознавцями (I. Р. Вихованець ${ }^{136}$ ， М. В. Леонова ${ }^{137}, \quad$ А. А. Лучик ${ }^{138}$, Н. I. Астаф'єва ${ }^{139}$,

${ }^{132}$ Вихованець I. Р. Прийменникова система української мови. Київ: Наукова думка, 1980. $286 \mathrm{c}$.

${ }^{133}$ Колодяжний А. С. Прийменник: матеріали до лекцій з курсу сучасної української літературної мови. Харків: Вид-во Харків. ун-ту, 1960. 165 с.

134 Лучик А. А. Російсько-український та українсько-російський словник еквівалентів слова. Київ: Довіра, 2003. 496 с.

135 Там само.

136 Вихованець I. Р. Прийменникова система української мови. Київ: Наукова думка, 1980. $286 \mathrm{c}$.

137 Леонова М. В. Сучасна українська літературна мова: Морфологія. Київ: Вища школа, 1983. $264 \mathrm{c}$.

138 Лучик А. А. Російсько-український та українсько-російський словник еквівалентів слова. Київ: Довіра, 2003. 496 с.

${ }^{139}$ Астафьева Н. И., К Киселев И. А., Кравченко 3. Ф. Современный русский язык: Служебные части речи. Модальные слова. Междометия. Минск: Вышэйшая школа, 1971. 80 с. 
В. С. Бондаренко ${ }^{140}$, Є. Т. Черкасова ${ }^{141}$, Г. Боума, Б. Вілляда ${ }^{142}$, С. Олівейра ${ }^{143}$ та ін.), а також встановленими за результатами власних досліджень.

Ознаками складених прийменників є:

1. Контактність компонентів.

Ця ознака є обов'язковою - ii врахування передбачалося вже на етапі формування ЛБД. Програму було орієнтовано на вибір контекстів лише прийменникових сполучень, що задовольняли цій умові. Тобто в ЛБД не включалися речення, в яких сполучення типу Prep N (з метою, за допомогою) зустрічалися 3 препозиційними означеннями до іменної частини. Порівн.: 3 метою порятунку - з реальною / цією/ чітко визначеною метою.

2. Наявність в постпозиції від ПСП (прийменникового сполучення претендента на роль складеного прийменника) іменної форми у визначеному відмінку.

Відсутність цієї ознаки, так само, як і ознаки компактності компонентів, вважається достатньою умовою для надання відповідному прийменниковому сполученню статусу синтаксичної прийменникової конструкції. Порівн.:

На базі (синтаксична конструкція) була розгалужена сітка залізничних колій та асфальтових доріг - відсутня залежна форма.

Індуїзм як давньоіндійська релігія склався на базі (СП) давнього брахманізму - $є$ залежна форма у родовому відмінку (брахманізму).

3. Набуття прийменниковим сполученням нового значення, яке не є сумою значень його компонентів.

Утворюючи з прийменником стале сполучення, повнозначне слово в певних текстових ситуаціях змінює своє категоріальне значення і набуває значення релятивності. Так, іменники у сполуках у межах, у разі, у випадку, з нагоди втрачають свої первинні значення і отримують інше семантичне навантаження, але вже не окреме, а у зв'язку з прийменником: у межах (чого) - лімітивне відношення; у разі (чого) / у випадку (чого) - відношення умови; з нагоди (чого) причинне відношення.

У разі несвоєчасного надіслання такої інформації пільги не надаються.

Розвиток значення релятивності призводить не тільки до зміни значення повнозначного слова, але й до зміни його синтаксичної функції. Воно перестає

${ }^{140}$ Бондаренко В. С. Предлоги в современном русском языке. Москва: Госучпедиздат, 1961.76 c.

141 Черкасова Е. Т. Переход полнозначных слов в предлоги. Москва: Наука, 1967. С. 19.

142 Bouma G., Villada B. Corpus-based Acquisition of Collocational Prepositional Phrases. Language and Computers, 2001.

${ }^{143}$ Oliveira C., Garrão M., Amaral L. A. Recognising Complex Prepositions Prep+N+Prep as Negative Patterns in Automatic Term Extraction from Texts. URL: http://citeseerx.ist.psu.edu/viewdoc/download?doi=10.1.1.473.5377\&rep=rep1\&type=pdf. 
бути окремим членом речення і разом 3 прийменником виступає формальним засобом вираження синтаксичних зв'язків у реченні.

4. Можливість заміни складеного прийменника простим без зміни значення.

За результатами досліджень встановлено, що ця ознака є релевантною для більшості українських прийменників типу Prep N: в ім'я (чого) $\leftrightarrow$ заради, 3 метою $($ чого) $\leftrightarrow$ для, під час $($ чого) $\leftrightarrow$ протягом, за винятком (чого) $\leftrightarrow$ крім, тощо:

За умов значного похолодання північні регіони Украӥни були майже не заселеними, за винятком (= крім) деяких стоянок на Дніпрі та Дністрі.

Зазначимо, що ця ознака складеного прийменника також застосовується для ідентифікування складених прийменників у португальській мові ${ }^{144}$.

За результатами аналізу граматичної та семантичної стійкості складених прийменників за описаними ознаками список прийменникових сполучень скоротився до 75. Ці сполучення було розглянуто з позиції переважання їх вживання в тексті в ролі прийменника. Для цього за контекстами з ЛБД складених прийменників визначалося співвідношення кількості вживань прийменникових сполучень у функції прийменника та як синтаксичної конструкції, представленої сполученням простого прийменника і повнозначного слова. Одержані показники були використані також для оцінки ступеня граматичної і семантичної стійкості досліджуваних сполучень. За емпірично встановленим порогом 50 \% зі списку були вилучені сполучення в (у) плані, в (у) силу, на чолі, на шляху, по лінї, у порядку, вважаючи на як такі, що мають низький ступінь стійкості.

До остаточного списку складених прийменників увійшли 69 прийменників, 44 яких належать до групи Prep N, 16 - до Adv Prep, 6 - до Prep N Prep $_{2}, 3$ - до V Prep.

До складених прийменників, на відміну від простих, висувається однозначна вимога щодо відмінка залежної іменної групи (родового, давального, знахідного або орудного). Відповідно до цього всі складені прийменники розподіляються на чотири групи: 1) СПД - складені прийменники, що беруть участь у керуванні залежною іменною формою в давальному відмінку: на зміну, на противагу (таких встановлено 2); 2) СП3 - беруть участь у керуванні залежною формою в знахідному відмінку: зважаючи на, невважаючи на, незважаючи на, 3 огляду на, у відповідь на (встановлено 5); 3) СПО - беруть участь у керуванні залежною формою в орудному відмінку: в / у порівнянні з, вслід / услід за, згідно з, нарівні з, одночасно з, паралельно з, порівняно з, поруч з, поряд з, разом з, спільно 3, слідом / слідком за, у зв'язку з (встановлено 13); 4) СПР - беруть участь у

${ }^{144}$ Oliveira C., Garrão M., Amaral L. A. Recognising Complex Prepositions Prep+N+Prep as Negative Patterns in Automatic Term Extraction from Texts. URL: http://citeseerx.ist.psu.edu/viewdoc/download?doi=10.1.1.473.5377\&rep=rep1\&type=pdf. 
керуванні залежною формою в родовому відмінку: відповідно до, на адресу, $y$ справі тощо (встановлено 49).

За даними ЛБД, частота вживання прийменникових сполучень претендентів на роль складених прийменників - у функції прийменника становить близько 93 \% від загальної кількості вживань у текстах усіх 69 встановлених нами складених прийменників. Серед них 19 сполучень актуалізують тільки функцію прийменника. Ці прийменникові сполучення було занесено в окремі списки відповідно до відмінка залежних іменних груп: залежно від, за рахунок, 3 урахуванням, на відміну від, під час, подібно до, стосовно до (СПР), незважаючи на, у відповідь на (СПЗ), в/у порівнянні з, вслід/услід за, згідно з, нарівні з, паралельно 3, порівняно 3, слідом/слідком за (СПО). При знаходженні таких сполучень у тексті розроблений в Фонді алгоритм передбачає об’єднання їх у складені прийменники й визначення відмінка залежної іменної форми, за яким буде уточнюватися граматичний код першої іменної словоформи в постпозиції від складеного прийменника. Запропоновано наступну схему граматичного маркування складених прийменників: у двокомпонентних складених прийменниках перший компонент втрачає свою частиномовну належність, другому приписується код прийменника 3 відповідним відмінком залежної іменної форми; у трикомпонентних складених прийменниках частиномовну належність втрачають і перший, і другий компоненти, а третьому приписується код прийменника. Між усіма компонентами складеного прийменника ставиться символ «_» (без пробілу):

У_випадку $<\mathrm{PB}>$ можливого $<\mathrm{AB}>$ конфлікту $<\mathrm{MB}>$ iз $<\mathrm{PE}>$ Тайванем $<\mathrm{JE}>$, авіаносець $<\mathrm{MA}>$ буде $<\mathrm{UI}>$ міменню $<\mathrm{FE}>$, $a<\mathrm{SC}>$ не $<\mathrm{Z0}>$ перевагою $<\mathrm{FE}>$. $<\mathrm{e}>$

В_залежності_від $<\mathrm{PB}>$ потреби $<\mathrm{FB}>\quad i<S C>$ ситуації $<\mathrm{FB}>$ можна $<\mathrm{X} 0>$ виступати $<\mathrm{UA}>\quad$ тим $<\mathrm{RE}>\quad$ чи $<\mathrm{SC}>\quad$ тим $<\mathrm{RE}>\quad$ «длангом $<\mathrm{ME}>$ », виставляти $<\mathrm{UA}>$ тих $<\mathrm{RT}>$ чи $<\mathrm{SC}>$ тих $<\mathrm{RT}>$ лідерів $<\mathrm{MI}>$. $<\mathrm{e}>$

Для решти 50 прийменникових сполучень, які в текстах аналізованої вибірки актуалізують функції як прийменника, так і сполучника, встановлювалися правила розмежування цих функцій за контекстними умовами.

Потреба у формальних правилах ідентифікації складених прийменників у тексті (тобто розмежування синтаксичних конструкцій типу «прийменник + повнозначне слово (+ прийменник)», «повнозначне слово + прийменник» від тих, де відповідні конструкції виступають у функції прийменників і вимагають вживання залежної іменної форми в певному відмінку) зумовлена тим, що в результаті першого етапу АМА тексту, що здійснюється в межах графемного ланцюжка між пробілами, компоненти складеного прийменника i компоненти сполучення простого прийменника із залежною іменною формою мають однакові 
морфологічні коди i, отже, не можуть бути ідентифікованими в програмний спосіб. Порівняємо:

Сергій $<\mathrm{JA}>\boldsymbol{н а} \_$знак $<\mathrm{PB}>$ (складений прийменник) згоди $<\mathrm{FB}>$ хитнув $<\mathrm{VR}>$ головою $<\mathrm{FE}>$.

Ібрагім $<\mathrm{JA}>$ підвів $<\mathrm{VR}>\quad$ очі $<\mathrm{NH}>\quad \boldsymbol{\mu} \boldsymbol{a}<\mathrm{PD}>\quad$ знак $<\mathrm{MD}>\quad$ (синтаксична конструкція), щзо $<\mathrm{SS}>$ знаходився $<\mathrm{YR}>$ ліворуч $<\mathrm{T} 0>$.

Нерозрізнення складеного прийменника i конструкції прийменник + залежна форма на подальших етапах автоматичного опрацювання тексту, зокрема, при машинному перекладі, призводитиме до некоректних варіантів перекладу, оскільки пошук перекладних еквівалентів для складних прийменників здійснюється за іншими принципами, ніж для сполучень прийменник + залежна відмінкова форма. Наприклад, речення Сергій на знак згоди хитнув головою буде перекладено російською як Сергей на знак согласия кивнул горловой (правильно: ... в знак согласия).

В алгоритмі ідентифікації складених прийменників інформація про відмінок залежної іменної групи є відправною і може задаватися різними способами. У наведеному прикладі вона задається через номер списку, до якого належить конкретний складений прийменник. Пошук залежної групи в тексті здійснюється за правилами опрацювання простих прийменників. Порівняємо:

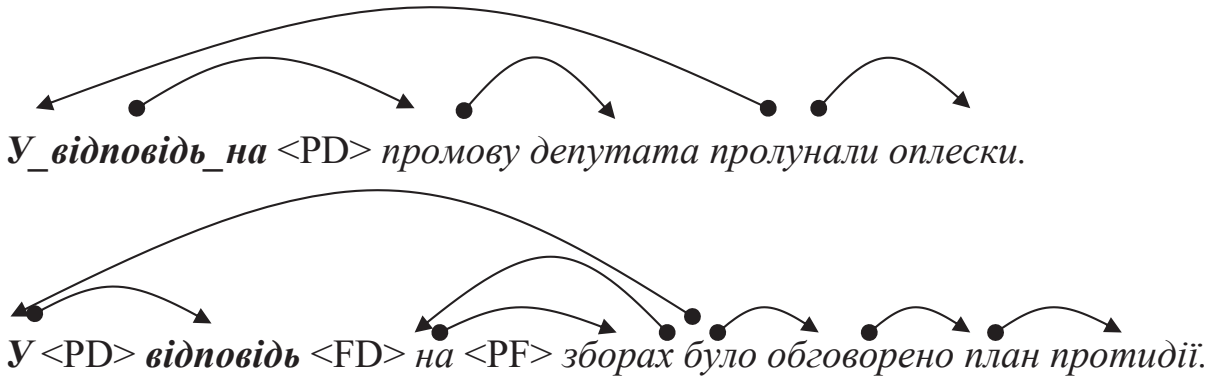

При визначенні діагностувальних контекстів, за якими ідентифікуються прийменникові сполучення - претенденти на роль складених прийменників (ПСП), в окрему групу виділено ті контексти, в яких вимагається давальний відмінок залежної іменної групи. Пор. «Головацький вийшов на зміну» «Головацький вийшов йому на_зміну».

Для решти ПСП пошук залежної форми здійснюється в правому контексті. Претенденти у складені прийменники не переводяться в складені прийменники за наявністю таких контекстуальних ознак:

1. Контактного розташування в постпозиції від ПСП розділових знаків \{. ; ! ? ... [ ] ( ) -\}: «I не кожному иче на_користь.»; 
2. Розташування в постпозиції від ПСП (контактно або через вставні слова) дієслова, присудкового слова, прийменника, прислівника, сполучника, частки, коми, двокрапки: «Студент, радий з_нагоди агітувати когось, охоче пояснював.»;

3. Правим контекстом претендента на роль СП $є$ кома 3 наступним сполучником підрядності: «Руйнації він піддається тільки у_разі, коли иъьому сприяють погодні умови»;

4. Перший справа від претендента на роль СП іменник, прикметник, дієприкметник, займенник або числівник має відмінкову форму, що не збігається 3 тією, яку вимагає відповідний СП: «Лише так можна пояснити азарт, з яким чечениі розправлялись із спійманими на базі блатними».

Для першої групи претендентів на роль СП наведені вище контекстуальні ознаки можуть розглядатися як достатні для ідентифікування функції прийменника за умови відсутності в постпозиції до нього іменної форми в давальному відмінку.

До необхідних контекстуальних ознак, що діагностують СП для всіх ПСП, належить контактне (постпозиційне - для другої групи і постпозиційне або препозиційне - для першої) розташування іменної форми у відмінку, «закріпленому» за відповідним СП. Як показав аналіз фактичного матеріалу, ця ознака для окремих ПСП не може вважатися достатньою при визначенні їхнього функціонального навантаження (в / у зв 'язку з; в / у залежності від; в / у світлі; в / y справі; на базі; на адресу; на зміну; на знак). Для таких ПСП необхідно аналізувати лексичне оточення. Так, у разі знаходження в препозиції до ПСП в/ у зв'язку з і в / y залежності від дієслів семантичного класу «існування» (перебувати, стояти, бути, опинятися, опинитися, залишатися, залишитися та ін.), ці ПСП не переводяться в СП: «Республіка опинилася в залежності від князя».

Для розпізнавання складених прийменників також використовується лексико-семантична інформація, наприклад, щодо семантичного класу слів у діагностувальних контекстах. Так, ПСП в / у справі не переходить до СП у разі знаходження в постпозиції до нього іменника з ознакою істота. Порівн.:

«У справі Андрія Бабицького виявлено нові обставини, які стосуються його участі в незаконних збройних формуваннях» (сполучення $У$ справі не отримує код прийменника).

«Прочедурні питання дедалі виразніше виступають на перший план у справі імплементації» (сполучення у справі отримує код прийменника ${ }^{145}$ ).

${ }^{145}$ Бугаков О. В. Автоматична ідентифікація складених прийменників в українському тексті. Актуальні проблеми украӥнської лінгвістики: теорія і практика: зб. наук. праць. Вип. 11. Київ: ВПЦ «Київський університет», 2005. С. 42-48. 
Окремо слід зазначити можливість входження прийменників в більші за складом конструкції - еквіваленти прислівників (на ходу; не в міру; на спад), еквіваленти сполучників (незважаючи на те, щзо; у міру того, як) та еквіваленти слова у функції вставного слова (на жаль; до речі; на нашу думку), що також задаються списками. У разі входження в одну з таких конструкцій, прийменник втрачає свої властивості і набуває властивостей цієї конструкції. Це зумовлює потребу в розробленні алгоритмів ідентифікування еквівалентів прислівника та еквівалентів сполучника на етапі АМА.

Застосування в системі АМА розроблених алгоритмів сприяє усуненню синтаксичної і семантичної неоднозначності, що значно покращує результати автоматичного лексичного маркування українського тексту.

\subsubsection{0. Дослідження функціонування прийменників на синтаксичному рівні}

Прийняте у Фонді поетапне синтаксичне маркування базується на методі фракційного синтаксичного аналізу, суть якого полягає в побудові синтаксичної структури речення з окремих фракцій - синтаксичних конструкцій певного типу, a саме: ланцюжків слів, об’єднаних предикативним зв’язком, іменних безприйменникових конструкцій, прикметниково-іменникових конструкцій, прийменникових конструкцій (зон прийменникових зв'язків). Шляхом об'єднання синтаксичних конструкцій можливо одержати повне представлення синтаксичної структури речення. Звідси й назва - фракційний синтаксичний аналіз.

Зона прийменникових зв'язків містить прийменник, головне слово, яке керує прийменниково-іменниковою синтаксемою, та залежне слово, яке підпорядковується головному за допомогою прийменника.

За результатами дослідження частоти вживання прийменників в українському тексті встановлено, що вони охоплюють 11,12\% тексту ${ }^{146}$, тобто належать до частотних синтаксичних явищ.

Внаслідок об'єктивного факту розгортання на лінійній структурі речення багатовимірної синтаксичної структури, що відображає зв'язки підпорядкування, при встановленні у тексті зон прийменникових зв’язків (ЗПЗ) виникають проблеми у разі:

1) дистантних зв’язків прийменника з головним та залежним словом;

2) недетермінованого пре- чи постпозитивного розташування ГС та ЗС стосовно прийменника, зумовленого вільним порядком слів у реченні, притаманним українській мові. Детальне дослідження контактного/ дистантного пре-/ постпозитивного розташування головного i залежного слова стосовно

${ }^{146}$ Бугаков О. В. Аналіз граматичної омонімії прийменників у мові й у тексті. Мовознавство, 2004. № 5-6. С. 87-98. 
прийменника допоможе визначити переваги позиційних властивостей кожного прийменника, що значно спростить алгоритм встановлення прийменникових зв'язків;

3) слабкого прийменникового керування, при якому вживання прийменника здебільшого зумовлене змістом, а не валентністю головного слова, що призводить до поширеного в українських текстах випадку наявності кількох потенційних головних слів прийменника. У такому випадку визначення справжнього головного слова можливе на основі ранжування потенційних головних слів або за умови використання семантичної інформації, що дуже ускладнює алгоритм встановлення прийменникових зв'язків;

4) ідентифікування зв’язків прийменника з головним та залежним словом в еліптичних конструкціях;

5) наявності однорідних головних і залежних слів.

При виборі параметрів опису ЗПЗ ми виходили з формально встановлюваної 3 тексту лінгвістичної інформації щодо: 1) морфологічних характеристик словоформ; 2) сполучувальних властивостей граматичних класів слів у межах певних синтаксичних конструкцій; 3) засобів пунктуації в реченні; 4) позиційних умов реалізації певних типів синтаксичних зв'язків; 5) лексико-статистичних та 6) лексико-семантичних параметрів ${ }^{147}$.

Перші з чотирьох зазначених типів інформації стосуються граматичного рівня і є основними при визначенні поверхневої синтаксичної структури речення. Морфологічна інформація отримується 3 кодів класів і підкласів слів, які приписуються всім словоформам після опрацювання тексту алгоритмами автоматичного морфологічного i контекстного аналізів. У модулі аналізу прийменникових зв'язків позиційні і пунктуаційні характеристики враховуються при визначенні інтервалів і меж пошуку головного та залежних слів у реченні, напрямку цього пошуку - в лівому чи правому оточенні прийменника, а також при встановленні факту наявності однорідних головних і залежних слів.

Необхідність звернення до лексико-статистичної та лексико-семантичної інформації випливає з умотивованості синтаксичних явищ семантикою. Лексична та семантична інформація використовується при визначенні головного слова прийменника, коли на основі лише граматичних ознак це не вдається зробити.

Інформаційною базою для визначення як граматичних і позиційних, так i семантичних ознак компонентів ЗПЗ послугувала ЛБД зон прийменникових зв’язків. Виведені на їі основі якісні та кількісні характеристики прийменникових зв’язків в українському тексті ${ }^{148}$ покладено в основу алгоритму встановлення зон

${ }^{147}$ Грязнухина Т. А. Анализ предложных связей в научном тексте. Киев: Наукова думка, 1985. 148 с.; Синтаксический анализ научного текста на ЭВМ / под ред. Т. А. Грязнухиной. Киев: Наукова думка, 1999. С. 31-32.

${ }^{148}$ Бугаков О. В. Зони прийменникових зв'язків у синтаксичній структурі українського речення. Мовознавство, 2005. № 5. С. 75-87. 
прийменникових зв'язків як окремого модуля АСА. Також передбачено їх використання для ідентифікації прийменникових конструкцій на етапі синтаксичного маркування УНЛК.

Розроблення лінгвістичних алгоритмічних процедур в АСА відбувається відповідно до принципів ${ }^{149}$ :

- доцільності (наприклад, для прийменників 3 переважанням постпозиційного розташування головного слова, пошук головного слова слід починати саме з цієї позиції);

- найбільшого виграшу (спочатку розглядаються зв'язки 3 найбільшою діагностувальною силою: наприклад, наявність контактного головного слова дієслова - зумовлює початок перевірки саме з цієї позиції);

— частоти вживання (спочатку розробляються алгоритми для найбільш частотних прийменників);

— раціональності (поступове ускладнення процедури перевірок).

Згідно з принципом доцільності, а також через можливість встановлення головного слова на основі залежного, алгоритм встановлення ЗПЗ у тексті повинен починатися 3 визначення залежного слова. По-перше, для залежного слова характерні обмежені синтагматичні контакти 3 прийменником, оскільки воно чіткіше визначене з погляду своєї позиції (переважно постпозиція стосовно прийменника) та граматичних характеристик (число класів, які можуть виконувати роль ЗС, обмежене), а отже, немає потреби залучати семантичну інформацію. По-друге, і це головне - на результати цього етапу АСА спираються наступні, на яких, зокрема, для пошуку головного слова використовуються семантичні характеристики залежного. Крім того, граматичні ознаки залежного слова можуть передбачати напрямок пошуку головного і встановлювати порядок перевірки лівого і правого оточення прийменника.

При визначенні залежного слова додатково вирішується завдання заміни омонімічних кодів (якщо такі залишились після АМА) на однозначні у будь-якого з учасників прийменникового керування, а також слів, що знаходяться в інтервалі «прийменник - залежне слово».

Попередній аналіз зон прийменникових зв’язків показав, що між прийменником і залежним словом ніколи не знаходиться жоден із компонентів предикативної пари. Крім того, прийменник i залежне слово не можуть знаходитися в різних предикативних частинах (ПЧ) складного речення.

Визначення залежного слова починається 3 перевірки правого контексту прийменника на наявність у ньому іменника, займенника-іменника або

${ }^{149}$ Аполлонская Т. А., Марашлец Е. Ф., Попескул А. Н. Устранение омонимии при АПТ. Инженерная лингвистика и оптимизация преподавания иностранных языков в вузе. Ленинград: ЛГПИ, 1983. С. 92-102. 
числівника, які виконують функцію залежного слова в 95,9\% від усіх зафіксованих випадків у ЛБД:

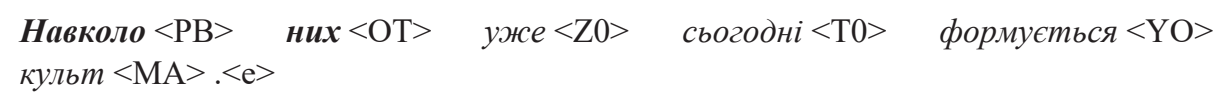

У разі наявності одного 3 цих класів передбачається перевірка відмінка словоформи, якій він приписаний, з інформацією про відмінок (відмінки), яким(и) може керувати конкретний прийменник (вони міститься у морфологічному коді прийменника). Якщо немає узгодженості, перевіряється правий контекст на наявність у ньому цифри, абревіатури або скорочення:
Під_час $<\mathrm{PB}>\quad$ виступу $<\mathrm{MB}>\quad$ в $<\mathrm{PF}>\quad$ альма-матер $<\mathrm{FF}>\quad$ Клінтон $<\mathrm{JA}>$ наголосив $<\mathrm{VR}>$ на $<\mathrm{PF}>$ необхіності $<\mathrm{FF}>$ продовження $<\mathrm{NB}>$ роботи $<\mathrm{FB}>$

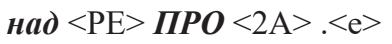

Праворуч від прийменника можуть знаходитись прислівник або частка, а також іменник, займенник-іменник, займенник-прикметник, прикметник, дієприкметник та числівник у невідповідному прийменнику відмінку, зв'язки яких згідно з принципами проективності структури українського речення не виходять за межі пошуку:

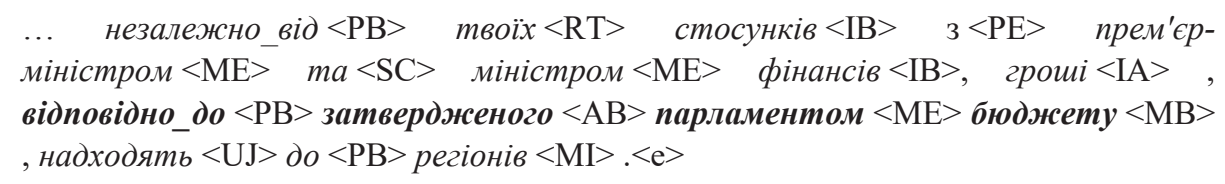

У цьому випадку перевіряються словоформи праворуч від зазначених класів, поки не буде знайдене 3С.

Прикметник, дієприкметник і займенник-прикметник в ролі залежного слова можуть виступати тільки у випадку еліпсиса, формальними ознаками якого є розташування праворуч від них крапки, крапки 3 комою, двокрапки, тире, прийменника або дієслова.

«Енергокомпанії $<\mathrm{FH}>$ мають $<\mathrm{UP}>$ можливість $<\mathrm{FD}>$ забезпечувати $<\mathrm{UA}>$ лише $<\mathrm{Z0}>100<1 \mathrm{~A}>$ млн. $<3 \mathrm{~A}>$, щзо $<\mathrm{OP}>$ становить $<\mathrm{UO}>17 \%<1 \mathrm{~A}>$ ві $<\mathrm{PB}>$ необхідного $<\mathrm{AN}>$. $\langle e>$ ».

Для прийменників вслід/услід, навздогін / наздогін, навперейми, назустріч / навстріч, наперекір, напереріз, на змін, на противагу, ради, заради після перевірки правого контексту перевіряється лівий на наявність у ньому контактно розташованих іменника та займенника-іменника у родовому (для ради, заради) або давальному (для інших прийменників) відмінках:

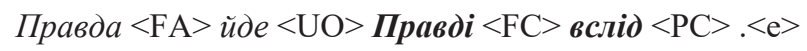


Справедливості $<\mathrm{FB}>\quad$ заради $<\mathrm{PB}>\quad$ відзначимо $<\mathrm{VF}>, \quad$ що $<\mathrm{SS}>\quad{ }_{3}<\mathrm{PE}>$ квітами $<\mathrm{IE}>$ на $<\mathrm{PF}>$ закритому $<\mathrm{AF}>$ кониерті $<\mathrm{MF}>$ було $<\mathrm{UT}>$ все $<\mathrm{OM}>$ гаразд $<\mathrm{T} 0>$. $<\mathrm{e}>$

Після завершення роботи алгоритму пошуку залежного слова до алгоритму пошуку головного передається інформація щодо позиції прийменника і залежного слова в реченні та граматичні характеристики останнього.

Наступним етапом роботи алгоритму є встановлення головного слова. Межами інтервалу його пошуку при перевірці препозитивного контексту є: слово в початковій позиції речення або предикативної частини, початок звороту (дієприкметникового або дієприслівникового), член предикативної пари, сполучення цифри з дужкою, яка вживається при переліку пунктів, підрядний або сурядний сполучник 3 попередньою комою. При пошуку головного слова в число об'єктів, які перевіряються на роль головного слова, включаються межі. Межею постпозитивного пошуку є: присудок (оскільки для аналізу подається текст 3 установленим предикативним центром), останнє слово речення або предикативної частини; для вставних конструкцій у дужках - дужка. При визначенні меж опускаються вставні конструкцій у дужках в лівому і правому контекстах і відокремлені звороти - у лівому.

Пошук головного слова починається з перевірки позиції прийменника. Якщо він знаходиться на початку речення або предикативної частини, головним словом визнається присудок (переважно виражений дієсловом, присудковим словом чи прикметником):

Незважсаюч_на $<\mathrm{PD}>\quad$ дві $<\mathrm{HV}>\quad$ поразки $<\mathrm{FK}>, \quad$ ми $<\mathrm{OS}>\quad$ не $<\mathrm{ZO}>$ втратили $<\overline{\mathrm{VU}}>\quad$ шансів $<\mathrm{MI}>\quad$ знову $<\mathrm{T} 0>\quad$ вийти $<\mathrm{VA}>\quad y<\mathrm{PD}>$ чвертьфінал $<\mathrm{MD}>$.<е $>$ - ГС у ЗПЗ прийменника незважаючи на виражене дієсловом втратили.

У випадку розташування прийменника не в першій позиції, при виборі напрямку пошуку ГС враховуються дані про співвідношення ліво- та правобічних зв'язків конкретних прийменників. Як показав попередній аналіз, обидва способи розташування властиві майже всім прийменникам (крім усправах; вглиб, на засадах, осторонь, у напрямі, усередину, для яких було зафіксовано виключно лівобічне розташування ГС), тому правила аналізу повинні враховувати як лівий, так і правий контексти, а проблема вибору напрямку пошуку зводиться до питання про порядок правил, за якими аналізуються відповідні контексти. Для прийменників 3 переважанням лівобічних зв'язків правила пошуку головного слова в правому контексті повинні працювати в останню чергу, а для наведених вище прийменників алгоритм повинен передбачати звернення до правого контексту як допоміжного, оскільки існує можливість постановки головного слова в постпозиції до прийменника. Для прийменників із переважанням 
правобічних зв'язків (згідно, незважаючи на, пріч, згідно з, на відміну від, попри) пошук головного слова, роль якого переважно виконують дієслово, присудкове слово, прикметник чи дієприкметник, розпочинається з правого контексту:

Примітно $<\mathrm{T0}>$, щуо $<\mathrm{SS}>$ згідно_з $<\mathrm{PE}>$ латвійським $<\mathrm{AE}>$ законом $<\mathrm{ME}>$ про $<\mathrm{PD}>$ приватизацію $<\mathrm{FD}>, \quad y<\mathrm{PF}>\quad$ крайні $<F F>$ не $<\mathrm{Z0}>$ існує $<\mathrm{UO}>$

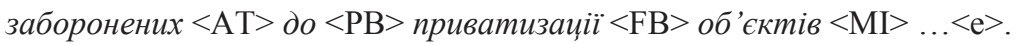

Для інших прийменників пошук головного слова починається 3 лівого контексту. Як показав аналіз зон прийменникових зв'язків, при розташуванні дієслова, присудкового слова, прикметника чи дієприкметника в контактній позиції до прийменника в 99,9 \% випадків вони виконують роль головного слова:

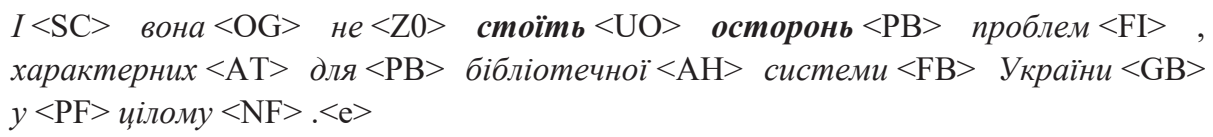

Для прийменників відповідно; довкруги; з-за, з-понад; з-поперед; обіруч; осторонь; між; мимо; на зразок; осторонь; просто; у справах, у контактній позиції до яких слова вищезазначених граматичних класів мають високу частоту вживання (більше 70 \%), ця перевірка проводиться в першу чергу.

При лівобічному розташуванні головного слова важливою $є$ інформація про переважання типу керування в прийменників - дієслівного чи іменного.

Для прийменників 3 переважанням дієслівного керування (до таких належить переважна їх більшість), алгоритм АСА передбачає пошук дієслова або присудкового слова у дистантній позиції стосовно прийменника, але в межах інтервалу пошуку, оскільки, як показали дослідження, прийменники, що мають частку дієслівного керування більшу, ніж іменного, в тексті надають перевагу віддаленим зв'язкам 3 дієсловом (або його формами), ніж близьким зв'язкам 3 віддієслівними іменниками (на відміну від прийменників, у яких переважає іменне керування):

Канівські $<\mathrm{AS}>\quad$ суддi $<\mathrm{MH}>\quad$ дійшли $<\mathrm{VU}>\quad$ висновку $<\mathrm{MB}>, \quad$ щзо $<\mathrm{SS}>$ Володимир $<\mathrm{JA}>$ скоїв $<\mathrm{VR}>$ убивство $<\mathrm{ND}>$ y $<\mathrm{PF}>$ стані $<\mathrm{MF}>$ афекту $<\mathrm{MB}>$, $i<\mathrm{SC}>$ звільнили $<\mathrm{VU}>$ його $<\mathrm{OB}>$ з-під $<\mathrm{PB}>$ варти $<\mathrm{FB}>$, де $<\mathrm{T} 0>$ він $<\mathrm{OA}>$ перебував $<\mathrm{UR}>$ під_час $<\mathrm{PB}>\quad$ слідства $<\mathrm{NB}>$ протягом $<\mathrm{PB}>10<1 \mathrm{~A}>$ місяиів $<\mathrm{MI}>$. $<\mathrm{e}>$

Головним словом у зоні прийменникового зв'язку прийменника протягом $\epsilon$ не контактно розташований іменник слідство, а дієслово перебувати, оскільки цей прийменник «віддає перевагу» дієслівному керуванню $(84,2 \%$ вживання в ЛБЗПЗ).

Для прийменників, у яких частка іменної залежності більше, ніж дієслівної (у справах; у галузі; з боку; на зразок; щүодо; між; у справі тощо), спочатку 
відбувається перевірка на пошук іменника 3 процесуальним значенням (розташованого як контактно, так і дистантно стосовно прийменника) у межах інтервалу пошуку:

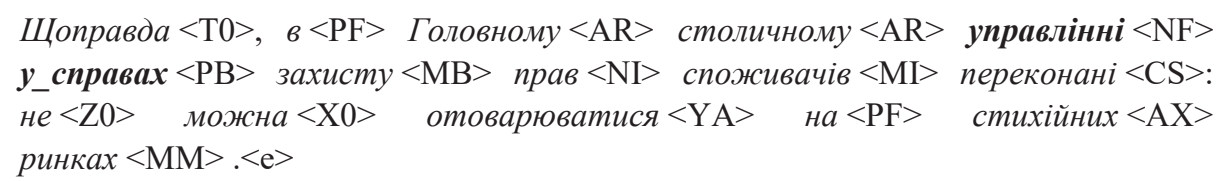

Виходячи 3 властивості проективності речень української мови, виключається можливість іменного керування прийменником при «вклинюванні» між ним та головним словом присудка, вираженого дієсловом, присудковим словом, прикметником чи дієприкметником. Відповідно, якщо головне слово прийменника - іменник, то він може знаходитись тільки в інтервалі між присудком та прийменником. Якщо в ланцюжку слів ліворуч від прийменника не знайдено іменника, який задовольняє ознаки ГС-імені, а в інтервалі знайдене слово, що належить до будь-якого 3 трьох граматичних класів (дієслово, прикметник, дієприкметник), то воно буде визначене головним словом прийменника.

Описаний вище принцип застосування правил пошуку головного та залежного слова $\epsilon$ спільним для всіх прийменників. До загальних правил відноситься також використання семантико-граматичної інформації, зокрема, перевірка словоформ, розташованих в препозиції до прийменника, на входження до класів icmoma і дія. Перший формально може бути виведений за номером парадигматичного класу, що визначається для кожної словоформи на етапі попереднього АМА. За результатами проведеного дослідження визначено прийменники, у яких функцію ГС може виконувати іменник-істота (без; в/y; від; для; до; з; за, на, під; по; біля; з боку; над; поза; понад; протягом; у галузі; внаслідок; з погляду; з-за; з-під; з-поміж; поміж; у ролі; у справах; на зразок; у випадку; у порівнянні з; посеред):

Новим $<\mathrm{AE}>$ авангардом $<\mathrm{ME}>$ революиії $<\mathrm{FB}>$ мали $<\mathrm{UU}>$ стати $<\mathrm{VA}>i<\mathrm{SC}>$ стали $<\mathrm{VU}>\quad$ студенти $<\mathrm{MH}>, \quad$ інтелектуали $<\mathrm{MH}>, \quad$ аутсайдери $<\mathrm{MH}>$ 3_погляду $<\mathrm{PB}>$ успішних $<\mathrm{AT}>$ буржуа $<\mathrm{MI}>$, mi $<\mathrm{OT}>$, хто $<\mathrm{OA}>$ щее $<\mathrm{T} 0>$ зберегли $<\mathrm{VU}>$ здатність $<\mathrm{FD}>$ до $<\mathrm{PB}>$ справд $i<\mathrm{T0}>$ революиійних $<\mathrm{AT}>$ diŭ $<\mathrm{FI}>$. $<e>$

При визначенні класу дія семантичні ознаки виводилися 3 граматичних ознак слова, заданих його граматичною семантикою. Клас формувався за списком квазіфлексій віддієслівних іменників, що містить кінцеві буквосполучення слів та їхніх словоформ, за якими в межах граматичних класів іменників можуть визначатися слова на позначення дії (-ання, -яння, -ення, -єння, -іння, -ація, -яџія, - 
иття, -яття, -уття, -ництво, -ство, -ність, -илля, -овка, -обка, -анню, -янню i т. д.):

Судова $<\mathrm{AG}>\quad$ реформа $<\mathrm{FA}>\quad \ldots \quad$ потребує $<\mathrm{UO}>\quad$ безперервного $<\mathrm{AN}>$ вдосконалення $<\mathrm{NB}>$ 3_метою $<\mathrm{PB}>$ утвердження $<\mathrm{NB}>$ незалежності $<\mathrm{FB}>$ судів $<\mathrm{MI}>i<\mathrm{SC}>$ судової $<\mathrm{AH}>$ влади $<\mathrm{FB}>\ldots<e>$

Але оскільки ці квазіфлексії можуть мати слова 3 іншою семантикою (населення, інформація, поняття), після перевірки за списком квазіфлексій відбувається порівняння словоформ зі списком заборон. Якщо ланцюжок початкових букв аналізованого слова не збігається з квазіосновами списку, воно може бути віднесене до віддієслівних іменників.

Визначення семантичних класів слів при формуванні поля 'Семантичні ознаки ГС' розглянемо на прикладі найчастотнішого прийменника української мови в /y в зонах з іменниковим керуванням. У ЛБ ПЗЗ для цього прийменника таких зон 619. Серед цієї кількості 37 словам за інформацією, одержаною в результаті АМА, приписувалася ознака icmoma. У 232 випадках для головного слова визначався клас дія на основі квазіфлексій віддієслівних іменників: -ення (101), -ання (59), -ність (29), -ація (27), -яття (4), -ництво (3), -іння, -иття, -овка (по 2), -яння, -илля, -обка (по 1):

Міністр $<\mathrm{MA}>\quad$ зазначив $<\mathrm{VR}>, \quad$ щзо $<\mathrm{SS}>\quad$ йдеться $<Y O>\quad$ ро $<\mathrm{PD}>$ інтеграцію $<\mathrm{FD}>\quad$ Югославї $<\mathrm{FB}>\quad$ в $<\mathrm{PF}>$ майбутньому $<\mathrm{AR}>\quad$ в $<\mathrm{PD}>$ Свропейський $<\mathrm{AD}>$ Союз $<\mathrm{MD}>$.<e $>$

Використання блоку правил для конкретних прийменників орієнтоване на неоднозначні ситуації, які репрезентують переважно прийменникове керування при дистантному розташуванні головного слова. Сюди ж потрапляють правила, що враховують лексико-статистичні характеристики прийменників, а також лексико-семантичні, які передбачають перевірку іменників на входження до семантичних класів (СК) - груп слів зі спільною семою в їхніх лексичних значеннях.

Семантичні класи задаються списками квазіоснов. Такий спосіб уможливлює представлення семантичних ознак різних граматичних класів i різних форм у межах одного класу. Наприклад, форми дієслів згуртувати; згуртуватися; згуртовувати; згуртовуватися (17/20/24/30 відповідно) ${ }^{150}$, дієприкметника згуртований (26), іменників згуртування; згуртовування та згуртованість (8/8/7 відповідно) можна представити у вигляді квазіоснови (початкового буквосполучення) згурm-, що значно скорочує списки слів, якими в

${ }^{150}$ Подано кількість можливих форм 3 урахуванням фонетичних $\mathrm{i}$ морфологічних варіантів. 
алгоритмі задаються семантичні класи ${ }^{151}$. Так, для прийменника в / $y$ ГС-іменники, що не увійшли до класів істота і дія (350 одиниць), було розподілено за 28 семантичними класами. Найбільшими 3 них є класи процес (переговори, побудова, рибальство), подія (арешт, вибух, виступ), рух (виїзд, експорт, перехід), захід (виставка, нарада, турнір), ставлення/ оцінка (невіра, недоцінка). При ідентифікації претендента на роль головного слова 3 квазіосновою зі списку, він отримує мітку головного слова в зоні прийменникового зв'язку:

Нині $<\mathrm{TO}>$ другий $<\mathrm{AA}>\quad$ симптом $<\mathrm{MA}>\quad$ совковості $<\mathrm{FB}>\quad$ химерно $<\mathrm{T} 0>$ поєднує $<\mathrm{UO}>$ невіру $<\mathrm{FD}>\quad$ в $<\mathrm{PD}>\quad$ спроможність $<\mathrm{FD}>\quad$ влади $<\mathrm{FB}>$ зробити $<\mathrm{VA}>$ щз-небудь $<\mathrm{OP}>$ корисне $<\mathrm{AP}>$ для $<\mathrm{PB}>$ краӥни $<\mathrm{FB}>$ з $<\mathrm{PE}>$ упевненістю $<\mathrm{FE}>$, що $<\mathrm{SS}>$ держава $<\mathrm{FA}>$ зобов'язана $<\mathrm{AG}>$ вирішити $<\mathrm{VA}>$ всі $<\mathrm{RV}>$ проблеми $<\mathrm{FK}>$ громадян $<\mathrm{MI}>$. $<\mathrm{e}>$

Алгоритми цього блоку включають правила, засновані на тих самих процедурах, і відрізняються один від одного числом процедур, їхніх комбінацій і списками, які використовуються для перевірки претендентів за семантичними ознаками. Порядок застосування правил установлюється за загальним принципом: спочатку відбувається перевірка за правилами, які описують граматичну або семантико-граматичну сполучуваність ГС i 3C, потім - за правилами, що визначають ГС на основі семантичних ознак слів, незалежно від граматичних характеристик, і тільки після цього здійснюється перевірка за правилами, які враховують семантико-граматичні і граматичні ознаки слів, що входять в інтервал пошуку. Порядок роботи правил для кожного блоку встановлюється на основі даних про кількість випадків ідентифікації ГС за кожним 3 цих правил (за матеріалами ЛБЗПЗ). Крім того, алгоритм передбачає звернення до семантичного словника прийменникових конструкцій, структура i функціональність якого описана вище.

Встановлення зон прийменникового зв'язку дозволяє розв'язувати проблеми синтаксичної неоднозначності, а також сприяє усуненню граматичної омонімії, яка залишилась після АМА.

\subsubsection{1. Дослідження функціонування прийменників на семантичному рівні}

Семантичне маркування ЛК передбачає приписування словам визначеної для них належності до певних семантичних класів та встановлення відношень між синтаксично зв'язаними словами. Через те що семантичні відношення визначають сполучуваність понять, а не словоформ, встановлення відношень у тексті має здійснюватися через аналіз семантичних контекстів синтаксично зв'язаних слів.

${ }^{151}$ Квазіоснова може дорівнювати словоформі. 
При семантичному аналізі цих контекстів вирішується проблема лексичної неоднозначності.

Значення ознаки, яке приписується відповідному імені у тлумачному словнику, відбиває найбільш стандартну поведінку, типові властивості цього об'єкта, але контекст може спричинити зміну лексикографічно фіксованого значення ознаки на контекстно-обумовлене значення ${ }^{152}$. Визначаючись високим ступенем узагальненості, значення прийменника - конкретне в кожному випадку - розкривається в контексті, у сполученні з іншими словами ${ }^{153}$. Аналіз семантики службових слів (у т.ч. прийменників) у складі словосполучень і речень дозволяє виявити множину аспектів їх використання, які не завжди очевидні при дослідженні семантики ізольованих слів ${ }^{154}$. Кожне значення багатозначного слова реалізується в певному семантичному контексті і переважно зв'язане з однією або кількома синтаксичними конструкціями ${ }^{155}$.

Семантичне маркування корпусу текстів, прийняте в Фонді, так само, як синтаксичне, базується на принципі часткового (фрагментарного) маркування (див. п. 20.2.5).

На вхід семантичного аналізатора надходить текст, в якому здійснено фрагментарне синтаксичне маркування, тобто розпізнаними $є$ синтаксичні конструкції певного типу (в наведеному нижче прикладі - прийменникові). Наприклад, у морфологічно промаркованому реченні зі знятою омонімією:

$\begin{array}{llrr}\text { У }<\mathrm{PF}>\quad \text { референдумі }<\mathrm{MF}> & \text { планується }<\mathrm{YO}> & \text { участь }<\mathrm{FA}>\quad i<\mathrm{SC}> \\ \text { палестинців }<\mathrm{MI}>, \quad \text { які }<\mathrm{OS}> & \text { мешкають }<\mathrm{UP}> & \text { за }<\mathrm{PE}>\quad \text { межами }<\mathrm{FL}> \\ \text { автономії }<\mathrm{FB}>\text {. }<\mathrm{e}> & & & \end{array}$

для зони зв'язків прийменника за синтаксичне маркування матиме такий вигляд: мешкають $<\mathrm{UP}><10 \mathrm{PR}>\quad$ $><\mathrm{PE}><11 \mathrm{PR}>$ межами $<\mathrm{FL}><12 \mathrm{PR}>$, де поруч 3 морфологічною інформацією приписується номер залежного слова у реченні і тип синтаксичного зв'язку - сурядний (SR), підрядний (керування (PR), узгодження (AR), прилягання (HR)) або зв'язок координації (KR).

Джерелом інформації про семантичні класи головних і залежних слів зони прийменникових зв'язків є семантичний словник прийменникових конструкцій, про який ітиметься далі. 3 нього береться також інформація про семантичне відношення, маркером якого виступає прийменник. Тому при семантичному маркуванні код відношення пропонується подавати саме біля прийменника 3 вказівкою номерів слів, які входять у зону прийменникових зв’язків:

152 Филипенко М. В. Проблемы описания предлогов в современных лингвистических теориях (обзор). Исследования по семантике предлогов. Москва: Русские словари, 2000. С. 12-54.

${ }_{153}^{153}$ Кучеренко І. К. Лексичне значення прийменника. Мовознавство, 1973. № 3. С. 22.

${ }^{154}$ Крейдлин Г. Е. Служебные слова в русском языке (семантические и синтаксические аспекты их изучения). Автореф. ... дис. канд. филол. наук. Москва: Изд-во Моск. ун-та, 1979. С. 9.

${ }^{155}$ Кустова Г. И., Ляшевская О. Н., Падучева Е. В., Рахилина Е. В. Национальный корпус русского языка как инструмент семантико-грамматического исследования лексики. НТИ. Сер. 2. № 6, 2005. С. 15. 
мешкають $<\mathrm{UP}><10 \mathrm{PR}><4>3 a<\mathrm{PE}><11 \mathrm{PR}><10,12, \mathrm{R} 72>$

межами $<\mathrm{FL}><12 \mathrm{PR}><16>$,

де поруч із синтаксичною інформацією для головного і залежного слів наводиться номер семантичного класу (згідно зі списком в окремому файлі), а для прийменника зазначаються порядкові номери головного і залежного слова в реченні та номер семантичного відношення, яке він виражає (семантичні відношення також задаються списком в окремому файлі).

Під семантичним відношенням розуміємо виражене мовними засобами відношення між предметами об'єктивної дійсності, позначуваними синтаксично зв'язаними словами.

Практика укладання формальних описів значень прийменників для потреб АОТ показала, що при перекладі зручно представляти контекстуальні значення прийменника як самостійні, не зв'язані одне з одним, і протиставляти кожному такому значенню контекстуальні умови, в яких воно реалізується ${ }^{156}$. У багатозначних прийменників не існує контекстно-незалежних значень: кожне 3 них реалізується в певному типі контексту і в цьому смислі пов'язано з ним. При визначенні умов реалізації того чи іншого значення прийменника необхідно встановлення семантичних ознак контексту ${ }^{157}$, роль яких виконують семантичні класи зв'язаних із прийменником слів, тобто головного і залежного слів.

Згідно $з$ теорією семантичних станів мовних одиниць, будь-яке слово (мовна одиниця) у контексті або в мовному потоці перебуває у певному семантичному стані, який для одиниць лексичного рівня $\epsilon$ сумою ознак граматичної і лексичної семантики.

Множину часткових семантичних станів, які відповідають власному значенню релятивності $f_{p}$ (клас прийменників), позначимо символом $G\left(f_{p}\right)$ :

$$
G\left(f_{p}\right):=\left\{g: F \cdot g=f_{p} \cdot g_{p}\right\}
$$

Проведення дослідження 3 метою виявлення множини часткових семантичних станів класу прийменників $G\left(f_{p}\right) \in$ необхідною передумовою створення семантичного словника прийменникових конструкцій.

Семантичний стан прийменника $X$ визначаємо як конкретне контекстуально зумовлене семантичне відношення (з вказівкою на відмінок залежного слова), яке виражає прийменник між синтаксично зв'язаними 3 ним словами, тобто 3 головним і залежним словами, і визначаємо як $g_{p}(X)$. Так, семантичним станом прийменника nid час є «відношення дії до проміжку часу, протягом якого вона відбувається» (темпорально-дименсивне 3 род.в.): звучати під час зустрічі.

${ }^{156}$ Никитина С. Е. О семантическом эллипсисе в предложных сочетаниях: к постановке вопроса. Проблемы лингвистического анализа: Фонология, грамматика, лексикология. Москва: Наука, 1966. С. 140-147.

157 Там само. 
Множину семантичних станів багатозначного прийменника $X$ визначаємо як $\left\{g_{p}(X)\right\}$.

Окремої уваги заслуговує синонімія прийменників. Відповідно до викладених вище формальних засад опису цього відношення, вважаємо, що лексеми $x$ та $y$ перебувають у відношенні синонімії $\boldsymbol{S}$ - цей факт позначаємо таким записом: $\boldsymbol{x} \boldsymbol{S} \boldsymbol{y}$, якщо існують семантичні стани, а саме, стани лексичної семантики - $\mathrm{c}(\mathrm{x})$ та $\mathrm{c}(\mathrm{y})$, що відповідають певним лексичним значенням розглядуваних лексем, які є близькими для всіх граматичних значень цих лексем: $\mathrm{c}(\mathrm{x}) \approx \mathrm{c}(\mathrm{y})$. Це означає, що:

$$
|c(x)-c(y)|<\varepsilon
$$

де $\varepsilon-$ певна достатньо мала величина.

Розглядаються тільки такі синонімічні ряди (синсети) S X, в яких якщо $X=\left\{x_{1}, x_{2}, \ldots, x_{n}\right\}$ - множина лексем, що становлять певний синсет $\mathrm{S} \mathrm{X}$, то $\mathrm{x}_{\mathrm{i}} \mathrm{S} \mathrm{x}_{\mathrm{j}}$ для всіх $\mathrm{i}, \mathrm{j}=1,2, \ldots, \mathrm{n}$. Це надає можливість позначити множину значень синсета $\mathrm{S} \mathrm{Хчерез} \mathrm{C}(\mathrm{SX})$. Отже, для будь-яких $\mathrm{c}(x) \in \mathrm{C}(\mathrm{S} \mathrm{X})$ та $\quad \mathrm{c}(y) \in$ $\mathrm{C}(\mathrm{S} X), \quad|c(x)-c(y)|<\varepsilon$.

При застосуванні описаного формального апарату до класу прийменників $P$ формуються синсети $\mathrm{S} P\left(\mathrm{P}=\left\{\mathrm{p}_{1}, \mathrm{p}_{2}, \ldots, \mathrm{p}_{\mathrm{n}}\right.\right.$, при $\mathrm{p}_{\mathrm{i}} \mathrm{S} \mathrm{p}_{\mathrm{j}}$ для всіх $i, j=1,2, \ldots, n$, для яких множина значень синсета S P позначається через C (S P).

Так, прийменники насеред, посеред, посередині об'єднуються в один синсет $\mathrm{S} \mathrm{P}_{i}$ на основі спільного для них відношення $\mathrm{C}\left(\mathrm{S} \mathrm{P}_{i}\right)$, яке вони виражають, а саме: «відношення дії до чого-небудь, в середині або в центрі якого вона відбувається» (локативне 5 з род.в.).

Вибір об’єктом дослідження семантики прийменника тріади «головне слово - прийменник - залежне слово», в якій прийменник виконує роль зв'язкового засобу між головним і залежним словами тріади, зумовлений тим, що значення зв'язкового засобу виражається іменем елементарного смислового відношення між двома текстовими одиницями $R(\mathrm{x}, \mathrm{y})$, де в позиції $\boldsymbol{x}$ і $\boldsymbol{y}$ знаходяться лексичні одиниці. Формула $R(\mathrm{x}, \mathrm{y})$ має певну передбачувальну силу: семантика слів, які виражають відношення, обмежує семантичні класи $\boldsymbol{x}$ i $\boldsymbol{y}$, i навпаки; а часто вистачає знання семантичних ознак двох або навіть одного члена тріади, щоб передбачити семантику інших ${ }^{158}$. При цьому важливими $\epsilon$ не тільки характеристики ізольованих лексем, а й відображення зв’язків між ними.

У досліджуваних конструкціях вирізняються такі смислові складники:

1) дескрипція А $(x)$, яка відповідає семантиці головного слова;

2) дескрипція В $(y)$, яка відповідає семантиці залежного слова;

158 Леонтьева Н. Н. Роль связей в семантической разметке корпуса текстов // Труды международной конференции «Корпусная лингвистика - 2004». СПб.: Изд-во С.-Петерб. ун-та, 2004. C. 201. 
3) відношення $\boldsymbol{R}, \quad$ встановлюване між сутностями, вказаними референційними $\boldsymbol{x}$ та $\boldsymbol{y}$, маркером якого виступає прийменник.

Відповідно, отримуємо таку логічну схему інтерпретації ${ }^{159}$ :

$$
A(y) \& \mathrm{~B}(x) \& \mathrm{R}(\mathrm{x}, \mathrm{y})
$$

де символом $\boldsymbol{\&}$ позначено кон'юнкцію.

Семантична характеристика прийменника визначається ланцюжками диференційних семантичних ознак, множина яких має вигляд тезауруса, що використовується як інструмент формалізації семантики прийменників ${ }^{160}$. Пошук одиниць тезауруса семантичних відношень прийменникових конструкцій відбувався шляхом використання мінімальних синтагматичних опозицій прийменникових контекстів (тобто зон прийменникових зв'язків). Проведене дослідження було зорієнтовано на створення саме такого тезауруса з метою подальшого його використання при укладанні семантичного словника прийменникових конструкцій.

Інформаційною базою для дослідження семантики прийменників послугувала створена у Фонді лінгвістична база зон прийменникових зв'язків (ЛБЗПЗ), описана вище.

За результатами проведеного на основі ЛБЗПЗ аналізу було виявлено 37 семантичних відношень, які при подальшій деталізації поділяються на 146 семантичних станів (конкретних семантичних відношень). Найбільш поширеними типами відношень є локативні ${ }^{161}$ (сидіти на східияях; побудувати поблизу заводу), директивні (рухатись на Захід; іти від джерела), об'єктні (стукати у двері; хапати за штани) і темпоральні (побачити об одинадиятій; статися усередині вересня), що підтвердилось і при аналізі прийменникових статей в 11-томному тлумачному «Словнику української мови» ${ }^{162}$. Типи семантичних відношень розглянемо на прикладі деліберативних відношень. Цей тип містить три семантичних стани (конкретні семантичні відношення): власне деліберативне, деліберативно-каузативне та деліберативно-сурсивне. Деліберативне відношення (відношення дії до особи, предмета або явища, яких стосується ця дія) можуть виражати 14 прийменників (відносно; до; довкола; з, 3 приводу; об; про; стосовно; стосовно до; у справах; у справі; щзодо): суперечка довкола постатей; торг з приводу призначення; задуматися над тим; мовчати об

${ }^{159}$ Рубашкин В. Ш. Словарная поддержка процедур семантической интерпретации предложных связей. Компьютерная лингвистика и интеллектуальные технологии: Труды междун. конф. «Диалог 2005» (Звенигород, 1 - 6 июня 2005 г.) / под ред. И. М. Кобозевой, А. С. Нариньяни, В.П. Селегея. Москва: Наука, 2005. С. 430-435.

${ }_{160}$ Аникина Н. В., Горбунов Ю. И. Формализация семантики предлогов с помощью тезауруса. Автоматическая переработка текста методами прикладной лингвистики. Кишинев: Кишиневский политехн. ин-т, 1977. С. 57.

${ }^{161}$ У роботі використано термінологію Г. О. Золотової: Золотова Г. А. Синтаксический словарь: Репертуар элементарных единиц русского синтаксиса. Москва: Наука, 1988. 440 с.

${ }^{162}$ Словник української мови в 11 томах. Київ: Наукова думка, 1970-1980. 
тім; писати про політику). Деліберативно-каузативне відношення (відношення дії до нагоди привітання) можуть виражати лише два прийменника (з; з нагоди); привітати з нагоди свята; привітати зі святом. I, нарешті, деліберативносурсивне відношення (відношення оцінки кого-, чого-небудь стосовно їі джерела) також виражають два прийменники (з; з погляду): нестабільний з економічної точки зору; непотрібний з погляду історії.

Одержану систему семантичних відношень прийменників покладено в основу ЕГС прийменникових конструкцій. При його створенні інтерпретація прийменникових сполучень виводилась шляхом зіставлення лексичної та семантичної інформації стосовно головного та залежного слів та потенційних можливостей прийменника передавати певні семантичні відношення.

На думку В. Ш. Рубашкіна, в реєстровій частині словника повинна подаватися інформація про семантичні класи головного та залежного слів («батька» (F) та «сина» $(\mathrm{S}))$. Можливі способи інтерпретації прийменникових зв'язків визначаються парою $<S C\left(D^{i}\left(W_{S}\right)\right), \mathrm{SC}\left(D^{j}\left(W_{F}\right)\right)>$, де $D^{i}(W)-i$-й лексичний варіант слова $W$, $S C$ - семантичний клас лексичного варіанта вказаного слова - «семантичний контекст інтерпретації прийменникового зв'язку» ${ }^{163}$. Вхід у такий словник відбувається або через прийменник, або через семантичні класи ГС та ЗС.

Завдяки структуруванню словникових статей розроблений у Фонді словник отримав, крім зазначених, додаткову точку доступу - через лексичну інформацію про головне та залежне слово (конкретні леми).

Структура словникової статті $V(x)$ семантичного словника прийменникових конструкцій як лексикографічної системи представляється в стандартному вигляді відповідно до теорії лексикографічних систем:

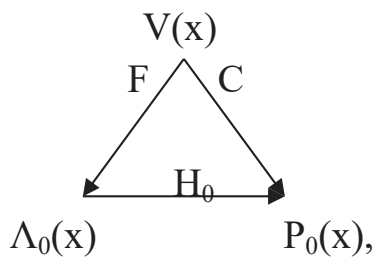

де $\mathbf{x}$ - реєстрове слово словника; F і C - оператори, що виділяють у тексті формальну і змістову частини опису реєстрової одиниці $\mathbf{x}-\Lambda_{0}(x)$ та $P_{0}(x), H_{0}-$ оператор, який забезпечує відповідність між $\Lambda_{0}(x)$ та $P_{0}(x)$; елемент $\Lambda_{0}(x)$ відіграє роль лівої (реєстрової), а $P_{0}(x)$ - правої (інтерпретаційної) частини словникової статті $V(x)$. Кожна з виділених частин, у свою чергу, поділяються на ліву та праву частину, тобто відбувається рекурсивна редукція другого порядку. Структура лівої частини набуває вигляду:

${ }^{163}$ Рубашкин В. Ш. Словарная поддержка процедур семантической интерпретации предложных связей. Компьютерная лингвистика и интеллектуальные технологии: Тр. междун. конф. «Диалог-2005» (Звенигород, 1-6 июня 2005 г.) / под ред. И. М. Кобозевой, А. С. Нариньяни, В. П. Селегея. Москва: Наука, 2005. С. 430-435. 


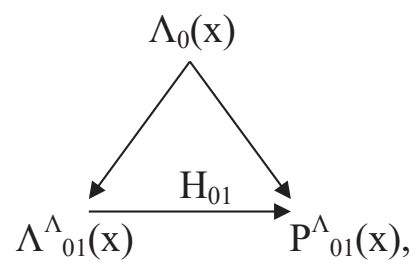

де $\Lambda_{01}^{\Lambda}(x)$ містить реєстрове слово (прийменник) та інформацію про його граматичну семантику, а $P_{01}^{\Lambda}(x)$ - головне та залежне слова та інформацію про їхню граматичну семантику. При подальшому поділі кожен із компонентів лівої частини виділяється в окремі блоки.

Структура правої частини набуває такого вигляду:

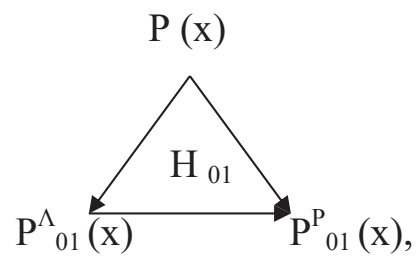

де в $P_{01}^{\Lambda}(x)$ фіксуються семантичні класи головного та залежного слів, а в $P_{01}^{p}(x)-$ семантичне відношення, яке виражає прийменник у конкретній прийменниковій конструкції.

Відповідно до цього, схема словникової статті семантичного словника має вигляд (табл. 20.10):

Табл. 20.10. Схема словникової статті семантичного словника

\begin{tabular}{|c|c|c|}
\hline ПРИЙМЕННИК $3 . . .8$. & ГС ч.м., ЗС ч.м. у ...в. & $\begin{array}{l}\Gamma C K-(\text { семантичний клас } Г C) \text {; } \\
3 C K-(\text { семантичний клас } 3 C) ; \\
\text { семант. віднош. }\end{array}$ \\
\hline
\end{tabular}

Для прикладу наведемо чотири словникові статті, розроблені для прийменника на (табл. 20.10).

Табл. 20.10. Приклади статей семантичного словника прийменника на

\begin{tabular}{|c|c|c|}
\hline НА з знах. $і$ міси. 6. & $\begin{array}{l}\text { ПРИХО\#ДИТИ } \\
\text { (ПРИЙТИ\#) дієсл., БАЗА\#Р } \\
\text { iм. у знах. в. }\end{array}$ & $\begin{array}{l}\text { ГСК - рух; ЗСК - місце; семант. } \\
\text { віднош. - директивне } 1 .\end{array}$ \\
\hline НА з знах. $і$ міси. в. & $\begin{array}{l}\text { ПРОВЕ\#ДЕНИЙ дієприкм., } \\
\text { ПРОХА\#ННЯ ім. у знах. в. }\end{array}$ & $\begin{array}{l}\text { ГСК- процес; ЗСК - процес; } \\
\text { семант. віднош. - каузативно- } \\
\text { спонукальне. }\end{array}$ \\
\hline НА з знах. $i$ міси. в. & 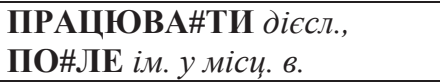 & $\begin{array}{l}\text { ГСК - процес; ЗСК - місце; } \\
\text { семант. віднош. - локативне } 1 .\end{array}$ \\
\hline НА з знах. $i$ міси. в. & $\begin{array}{l}\text { ПІДТВЕ\#РДЖУВАТИ } \\
\text { (ПІДТВЕ\#РДИТИ) дієсл., } \\
\text { СУД ім. у міси.. } . .\end{array}$ & $\begin{array}{l}\text { ГСК - мовленнєва діяльність; } \\
\text { ЗСК - установа; семант. віднош. } \\
\text { - об'єктно-лімітивне. }\end{array}$ \\
\hline
\end{tabular}


Семантичний словник є відкритою системою, інструментом автоматичного семантико-синтаксичного аналізу, що має результатом синтаксичне та семантичне маркування ЛК.

Розглянемо, як використовується семантичний словник у роботі синтаксичного та семантичного аналізаторів. На вхід аналізаторів поступає лематизований морфологічно розмічений текст (передбачається, що на окремому етапі АМА прийменник отримує однозначний код внаслідок усунення міжчастиномовної омонімії та визначення відмінка залежного слова).

На етапі синтаксичного аналізу звернення до словника відбувається у випадку, коли граматичних, позиційних та семантичних ознак недостатньо для однозначного визначення головного слова в ЗПЗ через наявність кількох формальних претендентів на цю роль. Наприклад, у реченні:

«Але $<\mathrm{SC}>$ проходження $<\mathrm{NA}>$ програми $<\mathrm{FB}>$ дій $<\mathrm{FI}>$ уряду $<\mathrm{MB}>$ иерез $<\mathrm{PD}>$ парламент $<\mathrm{MD}>$ показало $<\mathrm{VT}>$, що $<\mathrm{SS}>$ про $<\mathrm{PD}>$ взаєморозуміння $<\mathrm{ND}>$ та $<\mathrm{SC}>$ взаємопідтримку $<\mathrm{FD}>$ не $<\mathrm{Z0}>$ йдеться $<\mathrm{YO}>$. $<e>$ »

у прийменника через є кілька претендентів на роль ГС - іменники у препозиції проходження, програми, дій уряду та дієслово-присудок у постпозиції показало, які входять у межі інтервалу пошуку ГС. Ідентифікація претендента проходження 3 конструкцією у словнику вказує на те, що саме ця словоформа є головним словом у зоні зв'язків прийменника через.

На вхід семантичного аналізатора поступає інформація про ГС та ЗС (вони розмічені спеціальними мітками), в якому відбувається їх зіставлення із ГС та ЗС у семантичному словнику. При ідентифікації для синтаксичної конструкції визначається семантичне відношення. Наприклад, у реченні

«3a $<P E>$ погодженням $<N E>$ заиікавлених $<A T>$ сторін $<F I>$ було $<U T>$ оформлено $\langle V V>$ документ $\langle M D>$ про $\langle P D>$ списання $<$ ND $>$ боргів $<M I>$ енергоспоживачів $<$ II $>$ через $\langle$ PD $>$ взаємозалік $<M D>$. $\langle$ e $>$ »

у ЗПЗ списання $<\mathrm{ND}>$ через $<\mathrm{PD}>$ взаємозалік $<\mathrm{MD}>$ після звернення до словника головному та залежному словам приписуються номери їхніх семантичних класів, а прийменнику - номер семантичного відношення (медіативне) з вказівкою на номери позицій ГС та ЗС у реченні:

списання $<\mathrm{ND}><10 \mathrm{PR} ; 12 \mathrm{PR}><$ № CK $>$ через $<\mathrm{PD}><13 \mathrm{PR}><9,13, \mathrm{R} 97>$ взаємозалік $<\mathrm{MD}><-><$ № CK $>$

Якщо лексеми у словнику відсутні, передбачається можливість встановлення семантичного відношення за інформацією про семантичні класи головного та залежного слова. 
Іншим шляхом використання створених ЛБД та словника може бути формування семантичних класів головного та залежного слова. Зокрема, в окремі семантичні класи потраплятимуть ті залежні та головні слова, у яких збігається семантичне відношення конструкції. Інформація про семантичний клас використовується для семантичного маркування тексту - після звернення до словника ЗС та ГС отримуватимуть мітки конкретних семантичних класів.

Розроблені алгоритми та семантичний словник передбачається використати у роботі морфологічного та синтактико-семантичного аналізаторів як сервісних програм маркування УНЛК. У перспективі передбачається використання створених ЛБД та семантичного словника в системі машинного перекладу. Завдяки інформації, одержаної з ЛБД та словника, при перекладі з української на будь-яку іншу мову для слів зон прийменникових зв'язків буде зменшуватися або зводитися до одного кількість варіантів перекладних еквівалентів.

Як свідчить попередній аналіз багатозначних дієслів у тлумачному Словнику української мови ${ }^{164}$, в багатьох випадках формальним показником реалізованого в тексті конкретного значення (з кількох можливих) може слугувати входження дієслова в конкретну зону прийменникового зв'язку. Порівняймо переклад лексеми всувати / усувати російською та англійською мовами в залежності від входження цього слова в різні 3ПЗ:

- Пес то ховався, то знов голову всував у двері - Пес то прятался, то вновь всовывал голову в дверь - The dog was sometimes hiding, sometimes putting his head into the door.

- Контроль за виконанням завдань дозволяє своєчасно усувати недоліки в роботі - Контроль за выполнением заданий позволяет своевременно устранять недостатки в работе - A control of implementating the assignments allows to remove defects in work in time.

- Він усував із своїх творів іншомовні слова... - Он устранял из своих произведений иностраннье слова...- He eliminated foreign terms from his works...

При перекладі дієслова усувати без урахування ознаки «схема управління» система повинна запропонувати переклади: на російську мову -1 . всовывать +8 + вин.n.; 2. устранять + в + предл.n.; 3. устранять + из + род.n.; на англійську мову - 1. to put in (to); 2. to remove; 3. to eliminate. Враховуючи цю ознаку, система в усіх випадках зведе переклад до однозначних еквівалентів: в першому реченні всовывать / to put in(to), в другому - устранять / to remove, в третьому устранять / to eliminate.

Розроблені ЛБД $є$ інструментом та метою подальших семантичних досліджень.

${ }^{164}$ Словник української мови в 11 томах. Київ: Наукова думка, 1970-1980. 


\section{РОздІЛ 21}

\section{ДОСЛІДЖЕННЯ СТАТИСТИЧНИХ ПАРАМЕТРІВ УКРАЇНСЬКОЇ МОВИ}

\section{1. Постановка проблеми, мета та завдання статистичного дослідження мови. Історичний огляд досліджень зі статистики мови}

Дослідження статистичних параметрів природної мови набуває великого теоретичного і практичного значення, оскільки висвітлює найбільш глибинні іiі закономірності, пізнання яких надає можливість оптимізувати людино-машинні інтерфейси, що оперують 3 мовою. На виключне значення статистичних досліджень вказував ще видатний вітчизняний математик-статистик, учень Огюстена Коші $\quad$ В. Я. Буняковський $\quad(1804-1889)^{165}$. Ідеї статистичного дослідження мовних об'єктів відіграли велику роль у відкритті одного 3 найфундаментальніших типів випадкових процесів - ланцюгів Маркова ${ }^{166}$. Зазначені дослідження велися для багатьох мов світу. Для англійської, наприклад, у 1951 р. Клод Шеннон ${ }^{167}$ обчислив значення величини $\mathrm{H}_{0}=\log _{2} \mathrm{~N}$ (де $N$ кількість літер алфавіту), а також значення величин ентропії сукупності літер алфавіту $\left(\mathrm{H}_{1}\right)$; ентропії сукупності всіх пар літер, утворених 3 алфавіту $\left(H_{2}\right)$; ентропії сукупності трійок літер, утворених з алфавіту $\left(H_{3}\right)$ та також наближення для ентропії мови загалом $H$, яку Шеннон розглядав як границю умовних ентропій $F_{n}$ при $n \rightarrow \infty$. За Шенноном, ентропія мови - це статистичний параметр, який дорівнює середній кількості інформації, що припадає на одну літеру мови. Якщо вихідну мову перевести у двійкову форму найефективнішим способом, то ентропія $H$ дорівнює середньому числу двійкових знаків, які припадають на одну літеру вихідної мови: $F_{0}=H_{0}, \mathrm{~F}_{1}=\mathrm{H}_{1}, \mathrm{~F}_{2}=\mathrm{H}_{2}-\mathrm{H}_{1}, \mathrm{~F}_{3}=\mathrm{H}_{3}-\mathrm{H}_{2}, \ldots$ Отже, $\mathrm{F}_{2}$ являє собою умовну ентропію пар літер, якщо відомі перші дві літери кожної трійки.

Зрозуміло, що останні твердження у світлі досягнень в галузі теорії інформації від часів К. Шеннона, слід інтерпретувати із урахуванням обмежень, що накладаються на елементарні складники інформаційного процесу та зумовлюються його сутністю. Тобто, якщо за обчисленнями виявиться, що в літері «і» міститься інформації менше, ніж, скажімо, в літері «о», то цей результат

165 Яглом А. М., Яглом И. М. Вероятность и информация. Москва: Наука, 1973, С. 68-128, 236-273, 441-483.

${ }^{166}$ Романовский В. И. Статистические задачи, связанные с цепями Маркова. Ташкент: издтво УЗФАН, 1940.

${ }^{167}$ Шеннон К. Работы по теории информации и кибернетике. Москва: изд-во иностранной литературы, 1963. 
не слід екстраполювати за межі властивостей знакової системи мови i приписувати йому глибший лінгвістичний або навіть когнітивний смисл.

Завдяки зусиллям Р.Г. Піотровського та його колег ще в 50-60-ті роки минулого сторіччя одержано багато фактів про інформаційно-статистичні властивості російської та багатьох інших мов колишнього СРСР ${ }^{168}$.

Чимало досліджень зі статистики української мови було проведено в Інституті мовознавства ім. О. О. Потебні ${ }^{169}$. Проте, за браком відповідної експериментальної бази зазначені дослідження мали в основному констатаційний характер, і навіть тепер ми не можемо стверджувати, які з одержаних результатів репрезентують внутрішні властивості українського тексту, а які - ні. Наприклад, серед типових досліджень були такі, як вивчення середньої довжини речень у О. Гончара і П. Панча, причому робився обгрунтований висновок, що ця величина для творів О.Гончара дещо більша ${ }^{170}$. Хоча зазначені величини $i \quad \epsilon$ характеристиками стилю, але для того, щоб робити з них висновки, які мали б значення для мови загалом, очевидно, необхідно було проводити дослідження на набагато ширшому текстовому матеріалі. Такий матеріал в адаптованому для комп'ютерного опрацювання вигляді, а також відповідна технологічна база були недосяжними для наших попередників, отже завдання дослідження інформаційностатистичних характеристик українського тексту ab initio досі $\epsilon$ актуальним. Причому доцільно почати 3 надійного встановлення найбільш загальних фактів, які можна одержати шляхом комп’ютерного аналізу українських текстів.

Можливість для проведення таких досліджень надає УНЛК, у бібліотеці якого зібрані тексти української літератури загальним обсягом близько 200 млн слововживань ( 2 гігабайти). Зауважимо, що обсяг українських текстів, який було піддано статистичному опрацюванню у попередні періоди, не перевищував кількох мегабайт.

На сучасному етапі розвитку науки метою автоматичного опрацювання природної мови є виявлення, пояснення та характеристика багатоманітності лінгвістичних спостережень в мовленні, на письмі та в інших сферах вживання мови. Ця мета має декілька аспектів: вивчення того, як люди оволодівають мовою, говорять та розуміють мову; розуміння співвідношення «лінгвістичне висловлювання - світ»; розуміння лінгвістичних структур, за допомогою яких мова стає засобом комунікації (процеси «думка - мова»; «зміст - текст» та ін.).

${ }^{168}$ Пиотровский Р. Г. Информационные измерения языка. Ленинград: Наука, 1968; Статистика речи. Сб. научн. ст. / отв. ред. Р. Г. Пиотровский. Ленинград: Наука, 1968; Статистика речи и автоматический анализ текста. Сб. научн. ст. / отв. ред. Р. Г. Пиотровский. Ленинград: Наука, 1980.

1966.

${ }^{169}$ Перебийніс В. С. Статистичні та структурні лінгвістичні моделі. Київ: Наукова думка, ${ }^{170}$ Перебийніс В. С. Статистичні параметри стилів. Київ: Наукова думка, 1967. 
Зауважимо, що розробники лінгвістичних процесорів, зазвичай, не занадто заглиблюються в відношення мисленнєвих аспектів мови та ії представлення в письмовій формі.

У 1960-1985 pр. дослідники в галузях лінгвістики, психології, штучного інтелекту та опрацювання природної мови поділяли раціоналістичний підхід, який характеризується постулюванням ідеї генетичного успадкування знань. У лінгвістиці раціоналістична позиція стала домінуючою завдяки аргументам Н. Хомського про природжене володіння мовою. Щодо штучного інтелекту, то тут ідеї раціоналістів проявляються в намаганні створити системи розуміння за допомогою «ручного» закладання в них великої кількості початкових знань та мисленнєвого механізму для того, щоб скопіювати те, з чого починається людський розум. Н. Хомський обстоює необхідність цієї вродженої структури через те, що він бачить проблему «бідності стимулів». Він натякає, що важко простежити, як діти можуть вивчити таку складну річ, якою $є$ природна мова, 3 обмеженої вхідної інформації (різної якості та складності), котру вони сприймають протягом ранніх років. Раціоналістичний підхід намагається обійти цю складну проблему за допомогою постулювання того, що ключові моменти мови успадковуються - вони «вшиті» у мозок вже при народженні як частина людського генетичного спадку. Слід, однак, визнати, що в генетичному апараті людини таких спадкових «мовних» генів досі не виявлено.

Емпіричний підхід також починається 3 постулювання деяких когнітивних здатностей, наявних у людському мозку. Отже різниця між обома підходами не $\epsilon$ абсолютною, а полягає лише в ступені. Треба визначити як певну константу наявність деякої початкової структури в мозку, що мотивує його вибирати певні способи організації та узагальнення від почуттєвих входів до інших, оскільки навчання неможливе із цілком порожнього стану. Але опірною точкою емпіричних підходів є припущення того, що розум не починається з деталізованих множин принципів та процедур, специфічних для різних компонентів мови, та інших когнітивних наслідків (наприклад, теорій морфологічної структури, граматичного маркування тощо). Припускається, що розум немовляти починається із загальних операцій асоціації, розпізнавання образів та узагальнення, і це може бути застосовано до багатого почуттєвого сприйняття, доступного дитині для вивчення деталізованої структури природної мови. Емпіризм домінував у лінгвістичній науці періоду 1920-1960 pp., i, складається враження, що зараз знову починає відроджуватися. Емпіричний підхід до опрацювання природної мови передбачає, що ми можемо вивчати складну та велику структуру мови, визначаючи відповідну загальну модель мови, а потім включаючи значення параметрів, застосовуючи методи статистики, розпізнавання образів та інші на великому масиві природномовної інформації. 
Статистичні дослідження мають сенс на великих вибірках. У мовознавстві такими вибірками $є$ ЛК, що розглядаються як певні «замінники» мови. Приймаючи цей підхід, який базується на корпусах, дослідники посилалися на більш ранню підтримку ідей емпіриків британським лінгвістом, засновником Лондонської лінгвістичної школи Дж. Р. Фертом (John Rupert Firth), який висунув слоган: «Упізнайте слово за його оточенням!». Але емпіричний підхід, базований на корпусі, ймовірно, можна побачити більш ясно у роботі американських структуралістів («post-Bloomfieldians»), особливо у 3. Xаppica (Zellig Sabbettai Harris). Наприклад, 3. Харріс намагався винайти процедури експлікації структури мови. Незважаючи на те, що ця робота не була розрахована на застосування комп'ютерів (вона, ймовірно, є досить простою з погляду обчислень), але там висловлено думку, що докладний та якісний граматичний опис забезпечує компактну репрезентацію корпусу текстів.

Зупинімося ще на кількох відмінностях між емпіричним та раціоналістичним підходами. Раціоналісти та емпірики намагаються описати різні речі. Послідовники Н. Хомського (так звані «генеративні лінгвісти») намагаються описати мовний модуль людської свідомості (І-мова), для якого такі дані, як тексти (Е-мова) забезпечують лише непряме свідчення, яке може бути доповнено інтуїцією носія мови. Для емпіриків цікаво описати Е-мову, ніби вона справді існує. Н. Хомський у такий спосіб робить критичне розрізнення між лінгвістичною компетенцією, яка відображає знання мовної структури, що передбачається закладеним у свідомості носія мови, та лінгвістичним представленням у світі, що піддається впливу багатьох факторів, таких як обмеженість пам'яті та різних відволікаючих шумів у оточенні. Генеративна лінгвістика наводить аргументи того, що можна ізолювати лінгвістичні здібності та описати їх ізольовано, у той час як емпіричні підходи взагалі відхиляють це зауваження і прагнуть описати реальне використання мови.

Ця різниця лежить в основі сучасного відродження інтересу до техніки емпіриків для обчислювальної роботи. Під час другого етапу роботи над штучним інтелектом (приблизно 1970-1989 рр.) дослідники займалися наукою свідомості і кращий спосіб практичному застосуванню цієї науки побачили у побудові маленьких систем, які намагалися поводити себе, як розумні. Цей підхід виявив багато інших ключових проблем та підходів, які є досі актуальними, але ця робота може бути покритикована на грунті того, що вона має справу тільки з дуже малими проблемами та не забезпечує реального визначення загальної ефективності використаних методів. Останнім часом дослідники приділяють більшу увагу прикладним практичним рішенням, шукають методи, які можуть працювати на «сирому» тексті, в такому вигляді, в якому він існує в реальному світі, та об’єктивні порівняльні оцінки того, наскільки добре різні методи працюють. Цей новий наголос часом відображений у назві галузі «Мовна 
технологія» або «Мовне конструювання» замість ОПМ (Опрацювання Природної Мови - Natural Language Processing (NLP)). Нові напрямки зумовили появу продуктивних підходів у статистичних методах ОПМ завдяки зручності для автоматичного вивчення (індукція знань), зняття неоднозначностей, а також тому, що вони відіграють певну роль у лінгвістиці як науці.

Підхід Фонду до статистичного опрацювання природної мови подібний до шеннонівського, який пов'язує лінгвістичні події з імовірностями. На основі частотності мовної одиниці можна стверджувати, яка одиниця мови (фонема, морфема, лексема, речення ....) є «звичайною», а яка - ні. Водночас, якщо послідовники Н. Хомського концентруються на типах речень, що рідко зустрічаються у мові (тобто не розглядають мову як неперервну), практики статистичної ОПМ орієнтуються на закономірності, зв'язки мовних фактів та мову цілком в усіх її проявах.

Інтерес до статистичних методів підігрівається дослідниками, що вбачають перспективу статистичних методів у їхньому реальному практичному застосуванні до вирішення реальних проблем, які не підлягають вирішенню іншими методами ОПМ. Але якщо б статистичні методи були лише практичним інженерним підходом, наближенням до складних проблем мови, які наука ще не здатна виявити, тоді зацікавленість дослідників у цих методах, напевне, була би досить обмеженою.

Аргументом на користь імовірнісного підходу до пізнання є те, що ми живемо у світі, наповненому невизначеностями та неповною інформацією. Для того, щоб успішно взаємодіяти зі світом, потрібно вміти поводитися з такого типу інформацією. Когнітивні процеси краще формалізуються як імовірнісні процеси або $з$ використанням певної кількісної міри, яка враховує невизначеність або неповноту інформації. Отже, мова, яка є відображенням свідомості, піддається моделюванню та опрацюванню статистичними методами.

\subsubsection{Anapam статистичного дослідження мови. ЛК як експериментальна база дослідження}

Метою статистичного дослідження природної мови $є$ опис мовних фактів, явищ та зв'язків між ними, а також розв'язання певних лінгвістичних проблем методами теорії ймовірностей та математичної статистики.

Насамперед постає завдання визначити коло мовних явищ та фактів, що можуть бути дослідженими статистичними методами. Це завдання, можливо, є одним із найскладніших, оскільки від правильного вибору об'єктів дослідження залежить подальший результат роботи. Статистичні дослідження мови базуються на природномовних текстах як найбільш доступному і зручному матеріалі. Було виділено декілька рівнів об’єктів мови: знаковий, фонетичний та лексичний. 
Дослідження мови на знаковому рівні має на меті обчислення ймовірності появи певного знаку або послідовності знаків у тексті, виявлення «заборонених» сполучень знаків, наявність яких у тексті $\epsilon$ помилковою (така інформація $є$ важливою для побудови орфокоректорів) або, навпаки, виявлення типових для мови буквосполучень, підрахунку кількості інформації, що припадає на один або кілька знаків, моделювання мови на знаковому рівні та ін.

За статистикою фонетичної системи можливо встановити рівень відповідності фонетичної системи мови орфографічній; статистичні дані щодо фонетики мови є ключовими для синтезу мови.

Найбільш складними та різноманітними $є$ статистичні дослідження лексичної системи мови, що дають можливість згруповувати слова за частотами, укладати частотні словники мов, досліджувати сполучуваність лексичних одиниць та граматичних форм, виділяти фразеологізми 3 текстів, здійснювати автоматичний синтаксичний аналіз та автоматичне зняття омонімії.

Статистичні дослідження проводяться на корпусі текстів різних жанрів, вимогою до яких є абсолютна «чистота» - відсутність помилок і пропусків та повна відповідність оригіналу. Тексти корпусу підлягають спеціальному попередньому маркуванню відповідно до мети дослідження, в якому їх будуть використовувати.

Введемо поняття статистичного портрету тексту як множини його формальних статистичних ознак, отриманих шляхом статистичного опрацювання за певними принципами. Множина ознак складається з підмножин: статистика знакової системи (в тому числі для фонетичного (транскрибованого) варіанта тексту); статистика лексичної та граматичної системи; статистика синтаксичної системи.

Нехай маємо будь-який текст $T$, для нього визначимо систему відображень $\alpha_{a}: \mathrm{T} \rightarrow T_{a}$, де $\mathrm{T}_{\alpha}=\cup \mathrm{T}_{\alpha}^{\mathrm{i}}$, де $\alpha-$ властивість, $i-$ умовний номер властивості, за якою будується відображення.

Визначення. Пара $\left(\sigma_{a}, \mathrm{~T}_{a}\right)$ визначає статистичний портрет тексту $T$.

\subsection{2. Статистика знакової системи}

Підкреслимо, що всі подані нижче статистичні результати отримано науковцями Фонду на текстах УНЛК.

Позначимо через $A(U)$ узагальнену абетку української мови $U$, тобто скінченну множину всіх символів, які зустрічаються при графічному (писемному) зображенні текстів цієї мови. Вона $є$ ширшою від звичайної абетки української мови завдяки включенню до іiї складу знаків пунктуації, апострофа, спеціальних символів (включно із символами чисел) та пробілу. Отже $A(U)$ має таку структуру: 


$$
A(U)=F(U) \cup P(U) \cup S(U) \cup \pi,
$$

де $F(U)$ є звичайна українська абетка, записана у ії стандартному порядку:

$F(U)=\left\{f_{1}=A, f_{2}=5, f_{3}=B, f_{4}=\Gamma, f_{5}=\Gamma, f_{6}=Д, f_{7}=E, f_{8}=C\right.$,

$\mathrm{f}_{9}=Ж, \mathrm{f}_{10}=3, \mathrm{f}_{11}=\mathrm{I}, \mathrm{f}_{12}=\ddot{\mathrm{I}}, \mathrm{f}_{13}=\mathrm{h}, \mathrm{f}_{14}=\mathrm{h}, \mathrm{f}_{15}=\mathrm{K}, \mathrm{f}_{16}=Л, \mathrm{f}_{17}=\mathrm{M}$,

$\mathrm{f}_{18}=\mathrm{H}, \mathrm{f}_{19}=\mathrm{O}, \mathrm{f}_{20}=\Pi, \mathrm{f}_{21}=\mathrm{P}, \mathrm{f}_{22}=\mathrm{C}, \mathrm{f}_{23}=\mathrm{T}, \mathrm{f}_{24}=\mathrm{Y}, \mathrm{f}_{25}=\Phi, \mathrm{f}_{26}=\mathrm{X}$,

$\mathrm{f}_{27}=Ц, \mathrm{f}_{28}=$ Ч, $\mathrm{f}_{29}=\amalg, \mathrm{f}_{30}=Щ, \mathrm{f}_{31}=\mathrm{b}, \mathrm{f}_{32}=Ю, \mathrm{f}_{33}=$ Я, $\left.\mathrm{f}_{34}={ }^{\prime}\right\}$;

$P(U) €$ множиною знаків пунктуації:

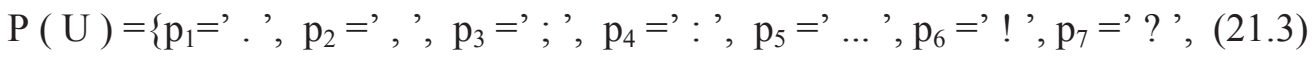
$\left.\mathrm{p}_{8}={ }^{\prime}-\mathrm{p}_{9}=\mathrm{p}^{\prime}, \mathrm{p}_{10}={ }^{\prime}\right)^{\prime}, \mathrm{p}_{11}={ }^{\prime}\left({ }^{\prime}\right\}$;

через $\pi$ позначено пробіл.

Об'єднання $F(U)$ та $\alpha$ позначимо через $Q(U)$ :

$$
\mathrm{Q}(\mathrm{U})=\mathrm{F}(\mathrm{U}) \cup\{-\}
$$

Подамо $F(U)$ у вигляді об'єднання:

$$
\mathrm{F}(\mathrm{U})=\mathrm{V}(\mathrm{U}) \cup \mathrm{C}(\mathrm{U}) \cup\{\mathbf{b}\} \cup\{\},
$$

де через $V(U)$ позначено голосні літери разом із літерою й, через $C(U)-$ приголосні літери. Множину (21.2) вважаємо повністю впорядкованою так, що на $F(U)$ відтворюється стандартний порядок слідування літер української абетки називатимемо цей порядок лексикографічним.

Назвемо узагальненим словом мови $U$ будь-яку скінченну послідовність елементів з множини $Q(U)$. Отже, якщо:

$$
Q(U)=\left\{q_{1}, q_{2}, \ldots, q_{n}\right\},
$$

то узагальнене слово $c^{n}$ довжини $n €$ :

$$
c^{n}=q_{i 1}, q_{i 2}, \ldots, q_{i n},
$$

де $q_{i k}$ належить до $Q(U), k=1,2, \ldots, \mathrm{n}$.

Оскільки вивчаються інформаційно-статистичні закони саме друкованої української мови, а не довільного тексту, в якому наявні українські вкраплення, то знаки (літери) інших мов, а також спецсимволи (математичні, хімічні формули, цифри, нотні знаки тощо) не враховуються при нашому аналізі. Тобто розгляд йде за множиною $\mathrm{Q}^{\prime}(\mathrm{U})=\mathrm{Q}(\mathrm{U}) \cup\{$ пробіл $\}$.

$$
\begin{aligned}
& \sigma_{\mathrm{zn}}: \mathrm{T} \rightarrow\left\{\left(\mathrm{q}_{1}, \mathrm{q}_{2}, \ldots \mathrm{q}_{\mathrm{k}}\right) ; \mathrm{P}\left(\mathrm{q}_{1}, \mathrm{q}_{2}, \ldots \mathrm{q}_{\mathrm{k}}\right)\right\}=\mathrm{T}_{\mathrm{zn}}, \mathrm{q}_{\mathrm{i}} \in \mathrm{Q}^{\prime}(\mathrm{U}), \mathrm{k}=1, \ldots, 10 \\
& \mathrm{~T}_{\mathrm{zn}}{ }^{1}=\{(\mathrm{q}) ; \mathrm{P}(\mathrm{q})\} \\
& \mathrm{T}_{\mathrm{zn}}{ }^{2}=\left\{\left(\mathrm{q}_{1}, \mathrm{q}_{2}\right) ; \mathrm{P}\left(\mathrm{q}_{1}, \mathrm{q}_{2}\right)\right\}
\end{aligned}
$$




\section{... \\ $\mathrm{T}_{\mathrm{zn}}{ }^{10}=\left\{\left(\mathrm{q}_{1}, \mathrm{q}_{2}, \ldots \mathrm{q}_{10}\right) ; \mathrm{P}\left(\mathrm{q}_{1}, \mathrm{q}_{2}, \ldots \mathrm{q}_{10}\right)\right\}$}

Маємо: $T_{z n}-$ знакова складова статистичного портрету тексту. Для отримання статистики фонетичної системи текст $T$ транскрибується, тобто під дією оператора транскрибування $\operatorname{tr}$ переводиться до вигляду $T^{t r}$, далі цей текст аналізується так само, як і звичайний, за тією відмінністю, що фонетична абетка

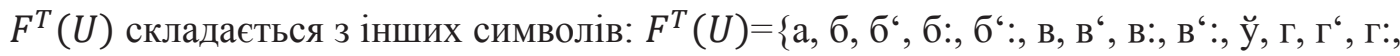

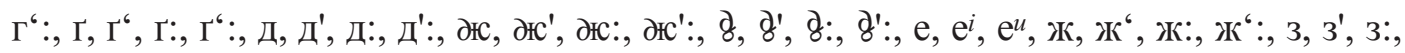

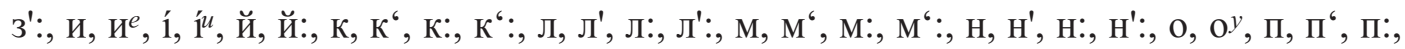

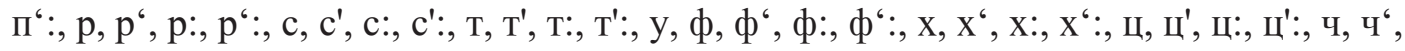
ч:, ч':, ш, ш', ш:, ш':\}. Через відсутність наголосів у словах однозначна ідентифікація граматичних омонімів, що в текстах відрізняються тільки позицією наголосу, неможлива.

Наявність потужної комп'ютерної техніки та достатньої кількості текстів дозволяють провести дослідження для знакової системи української мови, які К. Шеннон робив для англійської, і отримати більш точний результат, не докладаючи значних зусиль. В табл. 21.1 наведено розподіл літер української мови.

Аналогічні таблиці розподілів було отримано для комбінацій від двох до десяти літер, але наводити їх через великий обсяг не будемо. Помилки в текстах вибірок мають наслідком помилки в таблицях розподілу кількалітерних комбінацій, причому одна помилка в тексті дає десять не властивих мові десятилітерних комбінацій. Тому для дослідження доцільно обирати літеросполучення 3 абсолютною частотою більше 1 (чим більше літер у літеросполученні, тим менше серед них тих, що мають абсолютну частоту більше 1).

Таблиця 21.1. Залежність між довжиною літеросполучень та кількістю серед них тих, що мають абсолютну частоту більше 1

\begin{tabular}{|c|c|c|c|c|c|c|c|c|c|}
\hline \multicolumn{1}{|c|}{ Ранг літеросполучення } \\
\hline 1 & 2 & 3 & 4 & 5 & 6 & 7 & 8 & 9 & 10 \\
\hline 100 & $94,1 \%$ & $84,4 \%$ & $79 \%$ & $69,6 \%$ & $55,6 \%$ & $41,4 \%$ & $30 \%$ & $21,8 \%$ & $15,7 \%$ \\
\hline
\end{tabular}

Дволітерні сполучення, які зустрічаються в тексті один раз, не є характерними для української мови i, ймовірно, є помилковими: цй лш жг чг щю щї жй цч хж х’ шх хц тї мй їб яе ьж фя фз лф мї уь фц іь ег кь шз шг ги гї цг цї ю’ уи юе зє єі 'с єщ щп жє жх фч бф сй чж 'к їф їе ', иь щр єо фф ьу 'г ь' яь яф г' гє 'ж. Вибірку обсягом 170 Мб, на якій проводився статистичний експеримент, вважаємо репрезентативною для обчислення розподілу дволітерних буквосполучень. Для визначення властивих українській мові комбінацій літер на тексті граматичного словника української мови обсягом близько 3,3 млн 
словоформ був виконаний статистичний аналіз. 3 ЕГС української мови була отримана еталонна база літеросполучень, за допомогою якої можна ідентифікувати будь-яке літеросполучення як властиве чи невластиве українській мові. Недоліком еталонної бази $є$ те, що за нею можна ідентифікувати літеросполучення лише в межах слова, оскільки текст граматичного словника не $\epsilon$ змістовним та зв'язним, а являє собою впорядкований за абеткою список словоформ.

Моделлю тексту було обрано ланцюг Маркова 3 дискретним часом. Послідовність дискретних випадкових величин $X_{0}, \mathrm{X}_{1}, \ldots, \mathrm{X}_{n} 3$ множиною значень $M=\left\{m_{i}\right\}$ будемо називати однозв'язним ланцюгом Маркова 3 дискретним часом, якщо $\mathrm{P}\left(\mathrm{X}_{\mathrm{i}+1}=\mathrm{m}_{\mathrm{i}+1} \mid \mathrm{X}_{\mathrm{i}}=\mathrm{m}_{\mathrm{i}}, \mathrm{X}_{\mathrm{i}-1}=\mathrm{m}_{\mathrm{i}-1}, \ldots, \mathrm{X}_{0}=\mathrm{m}_{0}\right)=\mathrm{P}\left(\mathrm{X}_{\mathrm{i}+1}=\mathrm{m}_{\mathrm{i}+1} \mid \mathrm{X}_{\mathrm{i}}=\mathrm{m}_{\mathrm{i}}\right)$, тобто якщо наступне значення послідовності залежить лише від поточного, але не залежить від попередніх. Якщо наступне значення послідовності залежне від теперішнього та $\mathrm{n}$ попередніх, ланцюг Маркова $є$ n-зв'язним $\mathrm{P}\left(\mathrm{X}_{\mathrm{i}+1}=\mathrm{m}_{\mathrm{i}+1} \mid \mathrm{X}_{\mathrm{i}}=\mathrm{m}_{\mathrm{i}}, \mathrm{X}_{\mathrm{i}-1}=\mathrm{m}_{\mathrm{i}-1}, \ldots\right.$, $\left.\mathrm{X}_{0}=\mathrm{m}_{0}\right)=\mathrm{P}\left(\mathrm{X}_{\mathrm{i}+1}=\mathrm{m}_{\mathrm{i}+1} \mid \mathrm{X}_{\mathrm{i}}=\mathrm{m}_{\mathrm{i}}, \mathrm{X}_{\mathrm{i}-1}=\mathrm{m}_{\mathrm{i}-1}, \ldots, \mathrm{X}_{\mathrm{i}-(\mathrm{n}-1)}=\mathrm{m}_{\mathrm{i}-(\mathrm{n}-1)}\right)$. Якщо покласти $M=A(U)$, маючи розподіли літер та буквосполучень, неважко підрахувати ймовірності переходу $\mathrm{P}\left(\mathrm{X}_{\mathrm{i}+1}=\mathrm{m}_{\mathrm{i}+1} \mid \mathrm{X}_{\mathrm{i}}=\mathrm{m}_{\mathrm{i}}, \mathrm{X}_{\mathrm{i}-1}=\mathrm{m}_{\mathrm{i}-1}, \ldots, \mathrm{X}_{\mathrm{i}-(\mathrm{n}-1)}=\mathrm{m}_{\mathrm{i}-(\mathrm{n}-1)}\right)$, які покладено в принцип роботи генератора текстів.

За модель роботи генератора взято спочатку однозв'язний ланцюг Маркова (ймовірність переходу залежить лише від одного попереднього стану), який характеризується певними ймовірностями переходу (див. Додаток Б). Формується масив $A$ розмірності $36 \times 36$, в якому кожен елемент $A[i, j]$ являє собою ймовірність переходу на будь-якому кроці 3 символа 3 номером і у символ 3 номером $j$ у впорядкованій множині символів тексту. Ймовірності переходу заокруглюються до четвертого знака після коми в такий спосіб, щоби $\mathrm{A}[\mathrm{i}, 1]+\mathrm{A}[\mathrm{i}, 2]+\ldots+\mathrm{A}[\mathrm{i}, 36]=1 \quad \forall \mathrm{i}=1 . .36$. Потім на кожному кроці формується масив $B$ з 10000 символів за таким принципом: кожен із 36 символів входить у нього $10000 * A\left[i_{k}, j\right]$, де $i_{k}-$ номер поточного символа генерованого тексту на k-тому кроці (поточним вважається той символ, який було записано до генерованого тексту останнім), $j$ пробігає від 1 до 36.3 цього масиву за допомогою генератора випадкових чисел обирається символ, який записується у генерований текст; на наступному кроці все повторюється аналогічно $3 i_{k+1}$.

Так само можна побудувати генератор тексту, який працює на основі моделі ланцюга Маркова будь-якої зв'язності (відмінність буде лише у розмірності матриці). Наприклад, для роботи двозв'язного ланцюга Маркова (ймовірність переходу залежить від двох попередніх станів) розмірність матриці буде 1296 х 26 . Число 1296 - кількість всіх теоретично можливих дволітерних комбінацій; через те, що не всі теоретично можливі комбінації літер реалізуються на практиці, деякі рядки матриці будуть нульовими, тобто не підлягають врахуванню. 
На основі підрахунку ентропії писемних українських текстів одержано такі значення:

$$
\begin{aligned}
& \mathrm{H} 0=\mathrm{F} 0=\log 236=5,169: \mathrm{H} 1=4,487 ; \quad \mathrm{F} 1=\mathrm{H} 1=4,487 ; \\
& \mathrm{H} 2=8,085 ; \quad \mathrm{F} 2=\mathrm{H} 2-\mathrm{H} 1=3,598 ; \mathrm{H} 3=11,182 ; \quad \mathrm{F} 3=\mathrm{H} 3-\mathrm{H} 2=3,097 ; \\
& \mathrm{H} 4=13,767 ; \quad \mathrm{F} 4=\mathrm{H} 4-\mathrm{H} 3=2,585 ; \mathrm{H} 5=15,965 ; \mathrm{F} 5=\mathrm{H} 5-\mathrm{H} 4=2,198 ;
\end{aligned}
$$

\begin{tabular}{|l|c|c|c|c|c|}
\hline Модель генератора текстів & $\begin{array}{l}\text { Загальна } \\
\text { кількість } \\
\text { слів }\end{array}$ & $\begin{array}{l}\text { Середня } \\
\text { довжина } \\
\text { узагальне } \\
\text {-ного } \\
\text { слова }\end{array}$ & $\begin{array}{l}\text { Середня } \\
\text { довжина } \\
\text { слів у } \\
\text { словнику }\end{array}$ & $\begin{array}{l}\text { Кількість } \\
\text { українсь- } \\
\text { ких слів, } \\
\text { наявних у } \\
\text { словнику; }\end{array}$ & $\begin{array}{l}\text { Відсоток } \\
\text { слів, } \\
\text { наявних у } \\
\text { словнику }\end{array}$ \\
\hline $\begin{array}{l}\text { Дискретний стаціонарний } \\
\text { випадковий процес 3 } \\
\text { незалежними значеннями і } \\
\text { рівноймовірними станами }\end{array}$ & $\mathbf{2 5 3}$ & $\mathbf{1 5 , 8 3}$ & $\mathbf{0}$ & $\mathbf{0}$ & $\mathbf{0}$ \\
\hline $\begin{array}{l}\text { Дискретний стаціонарний } \\
\text { випадковий процес 3 } \\
\text { незалежними значеннями, } \\
\text { у якого розподіл станів } \\
\text { збігається з розподілом } \\
\text { символів тексту }\end{array}$ & $\mathbf{5 0 3}$ & $\mathbf{7 , 9 5}$ & $\mathbf{2 , 1}$ & $\mathbf{1 0}$ & $\mathbf{1 , 9 9}$ \\
\hline $\begin{array}{l}\text { Однорідний однозв'язний } \\
\text { ланцюг Маркова }\end{array}$ & $\mathbf{5 5 3}$ & $\mathbf{7 , 2 3}$ & $\mathbf{2 , 5 8}$ & $\mathbf{4 2}$ & $\mathbf{7 , 8 8}$ \\
\hline $\begin{array}{l}\text { Однорідний двозв'язний } \\
\text { ланцюг Маркова }\end{array}$ & $\mathbf{5 2 2}$ & $\mathbf{7 , 6 6}$ & $\mathbf{3 , 0 4}$ & $\mathbf{9 5}$ & $\mathbf{1 8 , 2}$ \\
\hline $\begin{array}{l}\text { Однорідний тризв'язний } \\
\text { ланцюг Маркова }\end{array}$ & $\mathbf{5 1 1}$ & $\mathbf{7 , 8 2}$ & $\mathbf{3 , 4 2}$ & $\mathbf{2 2 5}$ & $\mathbf{4 4 , 0 3}$ \\
\hline
\end{tabular}

\subsection{3. Транскрибована форма УНЛК та дослідження відповідності українського правопису фонетичному принципу}

Відповідність системи писемної мови іiі звуковій формі часто стає предметом жвавих дискусій. Для української мови ця проблема залишається актуальною в світлі обговорення обгрунтованості різних аспектів українського правопису, правомірності внесення тих чи інших змін у його сучасний варіант.

Українську писемність було засновано на засадах відповідності «звук літера», тобто основним (хоч, звісно, не єдиним) принципом українського або протоукраїнського письма був фонетичний. Але в процесі еволюції мови відбувалися відхилення від фонетичного принципу, через це зараз він витримується далеко не завжди. Сам характер писемності з погляду фонетичного і фонематичного принципів досі залишається предметом оцінних суджень. Між тим, наявність у Фонді репрезентативного списку українських слів, а також розроблена тут автоматична система парадигматизації української лексики, що 
дозволяє отримати в явному вигляді всі непочаткові форми слів ${ }^{171}$, робить цілком можливим кількісний аналіз відповідності написання українських слів їхньому звуковому вираженню. 3 огляду на значний обсяг української лексики, який на реєстрі близько в 200 тис. одиниць унаслідок розвиненості словозмінної системи української мови сягає 4 млн словоформ ${ }^{172}$, таке дослідження неминуче набуває статистичного характеру.

Вихідними міркуваннями дослідження $є$ такі. Якщо знак фонетичної транскрипції відповідає написанню слова за правописними правилами, написання цього слова $\epsilon$ фонетично адекватним. Якщо має місце лише часткова відповідність, ступінь фонетичності написання слова оцінюється шляхом обчислення відносної частки символів, які передаються аналогічними знаками фонетичної транскрипції.

Знаки письма вважаються відповідними знакам транскрипції у разі однакового позначення на письмі. Із 33 літер українського алфавіту 27 мають відповідники у фонетичній транскрипції (а, б, в, г, г, д, ж, з, к, л, м, н, п, р, с, т, у, ф, х, ц, ч, ш), 6 - не мають (с, ї, ю, я, ь, щ). До останніх також відносять апостроф, що не має відповідника у фонетичній транскрипщії. Тобто, в українській мові написання алфавітних літер переважно збігається з транскрипційними знаками. Якщо приголосні пом'якшені, за транскрипційним знаком, що позначає літеру, ставиться знак, яким позначається відповідний ступінь пом'якшення. Літера в у кінці складів передається як $\breve{\mathbf{y}}$; літери е, и, о мають по два транскрипційних відповідники: е та $\mathbf{e}^{\mathbf{u}}, \mathbf{и}$ та $\mathbf{u}^{\mathbf{e}}, \mathbf{0}$ та о $\mathbf{0}^{\mathbf{y}}$ відповідно; знаком й у транскрипції позначається як літера й, так і перша частина йотованих голосних; літера щ транскрипційно позначається двома літерами шч; африкати дж і дз позначають

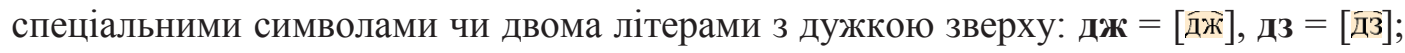
м'який знак позначається вертикальною рисочкою: «'». У транскрипції також відображаються основні та другорядні наголоси. 3 правилами транскрибування слів української мови, які було взято за основу роботи програми транскрибування, можна ознайомитися в орфоепічному Словнику української мови $(\text { ОСУМ })^{173}$.

Рівень фонетичності письма $F x$ визначатимемо як відношення кількості символів у тексті, які позначаються фонетичними відповідниками $L_{c}$ до загальної кількості символів (букв) у фонетичній транскрипції $L_{w}$. Зважаючи на те, що довжини слова і транскрипції є різними, доцільно використати таку формулу для підрахунку відсотка відповідності (ступеня фонетичності):

$$
F x=\frac{2 \sum L_{c}}{\sum L_{W}+\sum L_{T}} * 100 \%
$$

${ }^{171}$ Шевченко I. В. Алгоритмічна словозмінна класифікація української лексики. Мовознавство. 1996. № 4-5. С. 40-44; Шевченко I. В. Моделі та алгоритмічно-програмне забезпечення лексикографічних систем : Автореф. дис. ... канд. техн. наук. Київ, 2000. 19 с.

172 Інтегрована лексикографічна система «Словники України» / В. А. Широков та ін. Київ, 2004.

173 Орфоепічний словник української мови: В 2 т. / за ред. М. М. Пещак, В. М. Русанівського. Київ, 2001. 
Для проведення підрахунків застосовується певний корпус текстів або повний перелік зафіксованих словоформ. У першому випадку враховується частотність уживання тих чи інших слів і, відповідно, комбінацій тих чи інших літер (але при цьому певні графемні комбінації можуть не потрапити до вибірки). У другому випадку частоти вживання слів не враховуються, але подається повна картина словоформ та морфемних комбінацій в існуючих словоформах. Для проведення дослідження науковцями Фонду було обрано інший шлях. Предметом вивчення став масив українських словоформ, який для змінюваних лексем виводиться автоматично за допомогою процедури парадигматизації на основі словозмінної класифікації та ЕГС української мови, лексеми в якому проіндексовано за словозмінними класами. Експериментальний масив словоформ було сформовано з ЕГС української мови, що нараховував на той час понад 186 тис. лексем та близько 3,7 млн словоформ. Наголоси в вихідних словоформах було розставлено за українським Орфографічним словником (УОС) ${ }^{174}$, у похідних - відповідно до акцентуаційної класифікації української мови ${ }^{175}$. Кожну із словоформ було також автоматично протранскрибовано за допомогою спеціальної комп'ютерної програми, розробленої за правилами української фонетичної транскрипції, поданої в ОСУМ, й отримано пари «словоформа фонетична транскрипція».

Таблиця 21.2. Транскрибування словоформ

\begin{tabular}{|c|c|}
\hline Мова & {$[$ мо́ва] } \\
\hline Мови & {$[$ мо́ви $]$} \\
\hline Мові & {$[$ мо́в'і $]$} \\
\hline Мову & {$[$ мо́ву $]$} \\
\hline Мовою & {$[$ мо́войу $]$} \\
\hline
\end{tabular}

Тотожність знаків письма i транскрипції визначалася за повною відповідністю або за відповідністю знаків 3 наголосами звичайним ненаголошеним буквам українського письма. Так, у першому рядку знак о́ 3 правої колонки вважається тотожним букві о лівої колонки. Таке спрощення прийнято через послідовну відсутність знаків наголосу в українських текстах (крім деяких спеціальних: книжки для молодших школярів, навчальна література для іноземців тощо).

У результаті проведених обчислень для кожної пари «слово-транскрипція» отримано числову характеристику, яка дорівнює кількості символів, що збігаються.

Таблиця 21.3. Аналіз збігу символів у словоформі

174 Український орфографічний словник. Вид. 4 / за ред. В. М. Русанівського. Київ, 2005.

175 Шевченко I. В. Автоматизована дистрибуція наголосів у словозмінній парадигмі українського дієслова. Мовознавство, 2001. № 5. С. 26-30. 


\begin{tabular}{|c|c|c|c|c|}
\hline Слово & Транскрипція & $\begin{array}{c}\text { Кількість } \\
\text { символів у слові } \\
L_{W}\end{array}$ & $\begin{array}{c}\text { Кількість } \\
\text { символів у } \\
\text { транскрипції } \\
\text { L }_{\mathrm{T}}\end{array}$ & $\begin{array}{c}\text { Кількість } \\
\text { символів, що } \\
\text { збігаються } \\
\text { L }_{C}\end{array}$ \\
\hline степ & [степ] & 4 & 4 & 4 \\
\hline хліб & [хл'іб] & 4 & 5 & 4 \\
\hline дзеркало & [д̇е́ркало] & 8 & 7 & 6 \\
\hline починається & 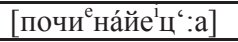 & 11 & 12 & 5 \\
\hline будь-хто & [буд’хтј] & 8 & 7 & 6 \\
\hline
\end{tabular}

Для кожного слова ступінь фонетичності обчислюється за такою формулою, яка $є$ простим наслідком формули (21.9):

$$
F x=\frac{2 L_{c}}{L_{W}+L_{T}} * 100 \% .
$$

Цей показник становить для першого рядка табл. $21.3 F x=\frac{2 * 4}{4+4} * 100=100 \%$, оскільки наголошене о́ транскрипції (права колонка) ототожнюється зі звичайним о (результати для інших рядків табл. 21.1 див. у табл. 21.4):

Таблиця 21.4. Обчислення ступеня фонетичності

\begin{tabular}{||l|c|c|c|c|c||}
\hline № & Слово & $\boldsymbol{L}_{\boldsymbol{c}}$ & $\boldsymbol{L}_{\boldsymbol{w}}$ & $\boldsymbol{L}_{\boldsymbol{T}}$ & $\boldsymbol{F \boldsymbol { x } ( \mathbf { \% } )}$ \\
\hline 1 & мова & 4 & 4 & 4 & 100 \\
\hline 2 & мови & 3 & 4 & 4 & 75,0 \\
\hline 3 & мові & 4 & 4 & 5 & 88,9 \\
\hline 4 & мову & 4 & 4 & 4 & 100 \\
\hline 5 & мовою & 4 & 5 & 6 & 72,7 \\
\hline \hline
\end{tabular}

Очевидно, що невідповідність між стандартним написанням і фонетичною транскрипцією для колонки $\boldsymbol{L}_{\boldsymbol{c}}$ табл. 21.4 виникає через передачу літери и через знак $\mathbf{u}^{\mathrm{e}}$, для колонки $\boldsymbol{L}_{\boldsymbol{w}}-$ через наявність у фонетичному варіанті написання знака пом'якшення, відсутнього у стандартному письмі, в колонці $\boldsymbol{L}_{\boldsymbol{T}}$ буква ю передається через два знаки фонетичного письма й та $\mathbf{~}$

Розглядаючи наведений набір 3 п'яти словоформ як певну вибірку із загального масиву, обрахуємо рівень фонетичності для цієї вибірки:

$2 \sum L_{c}$ дорівнює $2 *(4+3+4+4+4)=38$,

$$
\sum L_{W}=4+4+4+4+5=21 \text {, а } \sum L_{T}=4+4+5+4+6=23 \text {. }
$$

Тоді відповідно до формули (21.10):

$$
F x=\frac{2 \sum L_{c}}{\sum L_{W}+\sum L_{T}} * 100 \text { становить } \frac{38}{21+23} * 100 \approx 86,4 \% \text {. }
$$

Аналогічні підрахунки з формулою (21.10) було проведено на всьому масиві з 3,7 млн словоформ. За результатами підрахунків встановлено, що українські тексти, розглядувані як послідовність слів, на 76,7\% збігаються зі своєю транскрипцією.

Таблиця 21.5. Рівень фонетичності символів у масиві українських словоформ 


\begin{tabular}{|c|c|c|c|}
\hline Символ & Кількість у масиві & $\begin{array}{c}\text { Кількість } \\
\text { відповідностей у } \\
\text { масиві транскрипцій }\end{array}$ & Рівень фонетичності $\mathrm{F}_{\mathrm{x}}$ \\
\hline 1 & 48015 & 0 & 0 \\
\hline- & 68634 & 0 & 0 \\
\hline $\mathrm{a}$ & 2760049 & 2757090 & 99,9 \\
\hline 6 & 514549 & 508305 & 98,8 \\
\hline B & 1913692 & 1460382 & 76,3 \\
\hline$\Gamma$ & 567803 & 563357 & 99,2 \\
\hline I & 7469 & 7412 & 99,2 \\
\hline д & 856574 & 734626 & 85,8 \\
\hline $\mathrm{e}$ & 1744011 & 356509 & 20,4 \\
\hline$\epsilon$ & 199814 & 0 & 0 \\
\hline ж & 217677 & 164120 & 75,4 \\
\hline 3 & 712748 & 663714 & 93,1 \\
\hline и & 2245339 & 557877 & 24,8 \\
\hline i & 1737610 & 1735282 & 99,9 \\
\hline$\ddot{i}$ & 105560 & 0 & 0 \\
\hline й & 458373 & 458196 & 99,9 \\
\hline К & 1239151 & 1230113 & 99,3 \\
\hline л & 1382647 & 1374111 & 99,4 \\
\hline $\mathrm{M}$ & 1584210 & 1577046 & 99,5 \\
\hline $\mathrm{H}$ & 2401237 & 2254700 & 94,0 \\
\hline o & 3500959 & 3257258 & 93,0 \\
\hline$\Pi$ & 1181773 & 1174116 & 99,3 \\
\hline $\mathrm{p}$ & 1875913 & 1871017 & 99,7 \\
\hline $\mathrm{c}$ & 1507714 & 1428001 & 94,7 \\
\hline $\mathrm{T}$ & 1710612 & 1629247 & 95,2 \\
\hline $\mathrm{y}$ & 1441999 & 1426272 & 98,9 \\
\hline$\phi$ & 151271 & 148976 & 98,5 \\
\hline $\mathrm{x}$ & 388302 & 387357 & 99,8 \\
\hline ц & 227980 & 226601 & 99,4 \\
\hline ч & 459448 & 452804 & 98,5 \\
\hline Ш & 385905 & 369918 & 95,9 \\
\hline щ & 81401 & 0 & 0 \\
\hline b & 686208 & 0 & 0 \\
\hline$ю$ & 426560 & 0 & 0 \\
\hline я & 628415 & 0 & 0 \\
\hline
\end{tabular}

Що стосується рівня фонетичності символів у масиві українських словоформ, то нерівномірність розподілу літер за їхнею відповідністю у транскрипції пояснюється особливістю української правописної системи

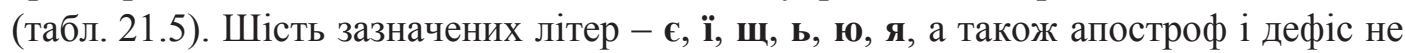
мають графічних відповідників у фонетичній транскрипції, хоча знак пом'якшення однозначно відповідає знаку вертикальної риски у транскрипції. Зрозуміло, що всі ці символи мають нулі у відповідних колонках табл. 21.5. 
Цікавим є факт досить низьких рівнів фонетичності для літер в $(76,3 \%)$, д $(85,7 \%)$, ж $(75,4 \%)$ і особливо е $(20,4 \%)$ та и $(24,8 \%)$. Це пояснюється регулярним вживанням цих літер на позначення різних звуків. Зокрема, буква в у нашій мові уживається для передавання щілинного приголосного [в] та напівголосного [y̆]. Широке розповсюдження цього останнього звука, зокрема в дієслівних формах чоловічого роду минулого часу, зумовлює високий відсоток невідповідності букви в іiі фонетичному вираженні у масиві українських словоформ. Низький рівень фонетичності літер д та ж зумовлений уживанням сполучення цих букв для позначення африкати [де]. Нарешті, напрочуд низький рівень $F_{X}$ для високочастотних голосних е та и пояснюється регулярним уживанням транскрипційних символів $\left[\mathrm{e}^{u}\right]$ та $\left[\mathrm{h}^{e}\right]$ відповідно на позначення специфічних голосних звуків у ненаголошеній позиції.

За результатами дослідження встановлено зв'язок фонетичності графічного образу словоформи та іiі частиномовної належності (табл. 21.6). Порівняно високий відсоток розбіжності транскрипції 3 правописною формою слова встановлено для дієслів та числівників. Цей факт неважко пояснити: для дієслів наявністю в словозмінній парадигмі форм на «-ться», для числівників - на «дцять», для яких вимова віддалено відповідає написанню, отже, графічній транскрипції ([ц':а] та [ц':ат'] відповідно).

Таблиця 21.6. Збіг із транскрипцією для словоформ різних частин мови

\begin{tabular}{||l|l|l||}
\hline \multicolumn{1}{|c|}{ Частина мови } & \multicolumn{1}{|c||}{$\begin{array}{c}\text { Загальна } \\
\text { кількість } \\
\text { словоформ }\end{array}$} & $\begin{array}{c}\text { Збіг із } \\
\text { транскрипціє } \\
\text { ю } \mathrm{F}_{\mathrm{x}}\end{array}$ \\
\hline Іменник & 922707 & 79,3 \\
\hline Прикметник & 959898 & 80,5 \\
\hline Дісслово & 1015115 & 73,6 \\
\hline Прислівник & 8712 & 81,3 \\
\hline Дієприслівник & 186 & 72,9 \\
\hline Дієприкметник & 330338 & 81,6 \\
\hline Числівник & 1738 & 72,1 \\
\hline Прийменник & 149 & 82,0 \\
\hline Частка & 124 & 84,7 \\
\hline Сполучник & 118 & 82,3 \\
\hline Займенник & 2945 & 74,1 \\
\hline Вигук & 492 & 78,7 \\
\hline Присудкове слово & 173 & 82,8 \\
\hline Вставне слово & 31 & 82,0 \\
\hline
\end{tabular}

Однак, стає зрозумілим, що еволюція української правописної системи не зруйнувала iї фонетичності. Вплив інших чинників на системи українського письма та вимови потребує окремих грунтовних досліджень. 


\section{РОЗдІЛ 22}

\section{КОРПУСНІ ТЕХНОЛОГІї В ЛІНГВОЕКСПЕРТНІЙ ДІЯЛЬНОСТІ}

\section{1. Лінгвістична експертиза: логіка проблеми}

Лінгвістичні корпуси надають інструментарій для проведення прикладних досліджень у нових, не зовсім традиційних для мовознавства галузях. Однією 3 таких галузей $є$ юридична лінгвістика - ділянка, що перебуває на межі право- та мовознавства, де останнім часом спостерігається значне підвищення активності.

Усталення демократії та поширення арбітражних (не авторитарних) методів розв'язання конфліктів, зокрема формально-судових, супроводжується розширенням сфери застосування лінгвістичного аналізу та експертизи текстів. Нерідко саме лінгвістичні методи відіграють вирішальну роль у розв'язанні тих чи інших конфліктів, насамперед - політичних. Не заглиблюючись аж надто у сферу лінгвістичного маніпулювання, на якому базуються виборчі кампанії, зауважимо, що їхні масштаби у новітній політичній історії України ще чекають всебічної оцінки лінгвістичної, юридичної, політологічної, морально-етичної та ін.

Активізація досліджень 3 лінгвістично-правової експертизи необхідна передусім для юриспруденції, оскільки чимало аспектів використання мови все ще не регламентовані правом. Ідеться про відсутність необхідного закону або статті закону, внаслідок чого не мають кваліфікації кримінальних такі діяння, як, наприклад, маніпулювання масовою свідомістю, певні різновиди сугестивної технології реклами, піару, передвиборчих кампаній, громадських акцій тощо. 3 іншого боку, застосування низки законів утруднене саме через відсутність лінгвістичної регламентації та коректної інтерпретації відповідних мовних ситуацій і феноменів. Зараз в Україні, на нашу думку, ще не розроблено науково коректних постановок завдань 3 юрислінгвістики як окремої галузі досліджень (хоча чимало публікацій на ці теми вже $\epsilon^{176}$ ), а відтак не розроблено відповідних навчальних програм і не налагоджено підготовку фахівців у цій галузі.

176 Див., наприклад: Копиленко О. Мовні проблеми в українській політичній думці та законодавстві 1917-1920рр. Право України. 1998. № 9. С. 44-48; Кравченко С. П. До питання про мову юридичного закону та іiі вплив на правову культуру суспільства. Актуальні проблеми держави і права. Зб. наук. праць. Одеса, 1998. С. 56-94; Прадід Ю. Ф. Юридична лінгвістика як окрема галузь знань // Вісн. Луганського ін-ту внутр. справ. 2001. № 3, С. 246-255; Прадід Ю. Ф. Зв’язок юридичної лінгвістики 3 іншими правознавчими дисциплінами // Матеріали III звітної наук.-практ. конференції проф.-викл. та курсант. складу Крим. ф-ту Нац. ун-ту внутр. справ. Сімферополь, 2001. Ч. 2. С. 137-143; Прадід Ю. Ф. Юридична лінгвістика - нова наукова спеціальність // Вісн. Львів. ін-ту внутр. справ. 2001. 
3 утвердженням громадянського суспільства в Україні лінгвістична експертиза набуде нових рис i, зрештою, неодмінно інституціоналізується, як це вже відбулося у багатьох країнах, де осередки лінгвоекспертної діяльності створюються та успішно функціонують при університетах, а на ниві лінгвістичної експертизи активно працюють сотні ліцензованих лінгвістів-експертів представників окремих фахових корпоративних угруповань.

\section{2. Лінгвістична експертиза: історія}

Лінгвістична експертиза віддавна входить до переліку інструментів дослідження в юридичній практиці, оскільки застосування закону передбачає проведення семантичного аналізу текстів (як самих законодавчих актів, так i текстів, авторами яких виступають суб'єкти правовідносин).

Багатовікова судова та адміністративна історія знає безліч випадків розгляду різних суперечок і непорозумінь, пов'язаних із текстами та їхнім тлумаченням, зокрема 3 нечітко сформульованими, неоднозначними фразами, неточним чи помилковим добором мовних одиниць, невдало вжитими зворотами в написаному (сказаному), що впливає на розуміння тексту - як друкованого (опублікованого), так і усного (проголошеного).

Потреба в лінгвістичній експертизі у зв'язку з судовим процесом виникала 3 античних часів. Так, за переказом академіка Я. К. Грота, один багатий римлянин заповів, щоби після його смерті була відлита його золота статуя зі стрілою в руці («поставити статую, що золоту стрілу несе»). Заповідач залишив для цього необхідну кількість дорогоцінного металу. Старший же син - головний виконавець заповіту батька - виконав наказ досить оригінально: він виготовив статую з каменю, в руці якої була золота стріла. Молодші брати висунули вимогу поділити залишки золота між усіма спадкоємцями. У відповідь старший брат послався на заповіт, витлумачивши його у такий спосіб: «Поставити статую, що золоту стрілу несе», - мовляв, батько й залишив золота лише на стрілу. Латина уможливлювала подібну фразу в заповіті, оскільки i statua (статуя), i sagitta (стріла) - жіночого роду, а застосована в оригіналі форма дієприкметникового звороту може бути віднесена до обох іменників.

Відомі сюжети із світової літератури, які також можна вважати лінгвістичними експертизами de facto. Яскравою ілюстрацією у цьому плані $є$ уривок з комедії П. Бомарше «Безумний день, або Весілля Фігаро» ${ }^{177}$ :

№ 2. С. 120-128; Кравченко С. П. Мова як фактор нормоутворення та правоутворення. Автореф. дис....канд. юр. наук. Одеса, 2000. 20 с.

${ }^{177}$ Бомарше П. Безумний день, або Весілля Фігаро. Комедія на 5 дій / Пер. 3 франц. С. Тобілевич; за ред. І. Кочерги. Київ: Мистецтво, 1951. С. 96-99. 
Дубль-Мен. ....Підійдіть, докторе, і прочитайте боргове зобов’язання.

Бартоло (читає): «Я, нижчепідписаний, свідчу, що отримав від панни і т. д. Марселіни де Верт Аллюр, в замку д’Агуас-Фреска, суму в дві тисячі піастрів, яку суму я зобов'язуюсь їй повернути, на першу іiі вимогу, в цьому замку та одружитись $з$ нею на доказ вдячності і т. д.» Підписано: «Фігаро». На мою думку, боржник повинен повернути борг і виконати зобов'язання, сплативши всі витрати. (Виголошує обвинувальну промову). Панове! Ніколи ще більш цікава справа не була поставлена на розгляд нашого суду. 3 часів Олександра Великого, який обіцяв одруження прекрасній Телестріс...

Граф (перебиває). Але перше ніж піти далі, пане повірений, треба переконатись, чи визнає обвинувачений законність цього документа.

Брідуазон (до Фігаро). Що ж ви мо-можете сказати про те, що тут прочитали?

Фігаро. А те, що з лукавства, через помилку або неувагу документ цей було прочитано неправильно, бо в документі не сказано, що: «яку суму я зобов'язуюсь їй повернути та одружитись 3 нею», а: «яку суму я зобов'язуюсь їй повернути або одружитись 3 нею», - а це зовсім інше.

Граф. Як там стоїть в умові — «та» чи «або»?

Бартоло. Тут написано «та».

Фігаро. Там написано «або».

Брідуазон. Дубль-Мен, прочитайте самі!

Дубль-Мен (бере nanip). Це буде певніше, бо часто позивники перекручують, читаючи. (Читає). Е-е-е... Панна е-е-е де Верт Аллюр... е-е-с... А! «...яку суму я зобов'язуюсь їй повернути, на першу її вимогу, в цьому замку... та... де... або... та... або...» Слово погано написано... та тут все ще й чорнильна пляма...

Брідуазон. П-п-пляма? Розумію!

Бартоло. Я стверджую, що тут $є$ сполучник «та», який зв’язує дві рівносильні частини речення: «я заплачу пані та одружусь 3 нею».

Фігаро (так само). Я стверджую, що це $\epsilon$ сполучник розділовий — «або», який розділяє вищесказані частини: «я заплачу пані або одружусь 3 нею». Коли він буквоїд, то я ще більший. Коли він хитрий, то я ще хитріший, — я його зажену на слизьке.

Граф. Як же судить у подібному випадку?

Бартоло. Щоб розв'язати питання, не варто сваритись із-за одного слова; нехай це буде «або».

Фігаро. Я прошу записати це в протокол.

Бартоло. Ми на це згодні. Такий хитрий підхід не врятує винуватця, який повинен буде і сплатити борг, і одружитись 3 позовницею згідно внутрішнього змісту документа.

Фігаро. Нічого подібного! Пан Бартоло думає, що я забув синтаксис i правила граматики. Зміст документа ясний: або я заплачу їй гроші, кома, або одружусь 3 нею...

Бартоло (ивидко). Коми немає.

Фігаро (швидко). Вона там є. Кома, або одружитись 3 нею.

Бартоло (дивиться на документ, ивидко). Коми немає, панове!

Фігаро (щвидко). Вона там була, панове. Крім того, де це ви бачили, щоб чоловік, який одружується, ще й платив борг своїй жінці!

Відзначимо кваліфіковане використання лінгвістичних фактів фігурантами цього епізоду. Вони із знанням справи тлумачать функції сполучників - чи то $€$ 
«сполучник “ma”, який зв’язує дві рівносильні частини речення», чи, навпаки, «сполучник розділовий “або”, який розділяє вищесказані частини»; посилаються на синтаксис і граматику.

Хрестоматійними в юридичній практиці стали випадки розгляду з приводу слів і виразів, сприйнятих адресатами тексту як інвектива - образа особи адресата або наклеп на неї. Наприклад, згадаймо хоча б філологічно-юридичний казус, описаний М.В.Гоголем в повісті «миргородського» циклу «Про те, як посварилися Іван Іванович з Іваном Никифоровичем»:

«Відомий усьому світові своїми богосупротивними вчинками дворянин Іван, Никифорів син, Довгочхун, - писав Іван Іванович Перерепенко до суду, сього 1810 року, іюля 7 дня учинив мені смертельну обиду... Оний дворянин... назвав мене публічно обидним та поносним для честі моєї йменням, саме: гусаком, тоді коли відомо всьому Миргородському повіту, що сею гнусною тварюкою я ніколи аж ніяк не іменувався і наперед іменуватися не збираюсь».

Із введенням у Росії в 1864 р. суду присяжних беруть свій початок і так звані «лінгвістичні» вироки. Один з них був винесений 1865 р. за словесну образу i опублікований у тогочасних газетах:

«Московский окружной суд признал доктора медицины Ельцинского виновным в оскорблении частного пристава Врубеля неприличным словом “безобразия”. На основании ст. 104, 110 Уложения о наказаниях Ельцинский подвергнут денежному взысканию трех рублей серебром».

Численні приклади лінгвістичних експертиз із сучасної судової практики Росії, наведені у книзі «Цена слова» ${ }^{178}$, переконують у їхній високій «запитаності». Зрозуміло, що подібних казусів і судово-лінгвістичних колізій, які потребують застосування юридично-лінгвістичних методів, не бракує і в Україні. Хоч процеси, описані у зазначеній книзі, ще не набули в нас значного розвитку.

Показовою в цьому плані є діяльність створеної у 2000 р. російської Гільдії лінгвістів-експертів $з$ документаційних та інформаційних суперечок (ГЛЕДІС), головна мета якої - сприяння через експертну діяльність професійних російських лінгвістів збереженню та розвитку російської мови у 3МI та в сучасному російському суспільстві, посилення лінгвістичної безпеки Росії, оскільки мова $є$ найважливішою складовою частиною інформаційного середовища та культури.

У статуті цієї організації відзначено, що члени Гільдії присвятили себе служінню науці та закону в ім'я повноцінного розвитку в Росії громадянського суспільства. Одним із своїх пріоритетних завдань Гільдія вважає допомогу співробітникам редакцій 3МI, працівникам правоохоронних органів, адвокатам, позивачам та відповідачам цивільних i кримінальних справ, учасникам

${ }^{178}$ Цена слова: Из практики лингвистических экспертиз текстов СМИ в судебных процессах по искам о защите чести, достоинства и деловой репутации / Под ред. М. В. Горбаневского. Москва: Галерия, 2001. 184 с. 
арбітражних спорів у проведенні експертизи лексичних одиниць і текстів; формування у регіонах Росії кваліфікованого корпусу експертів-лінгвістів, котрі діють за підтримки ГЛЕДІС на основі єдиної наукової бази і сучасних методик аналізу текстів; захист культури мови та поліпшення корпоративної репутації російських 3МI; участь у комплектуванні бібліотек навчальних i наукових установ, редакцій 3МI, правоохоронних органів методичними та довідковими виданнями з лінгвістичних експертиз; розроблення основ спеціальних навчальних курсів з лінгвістичної експертизи та лінгвістичної безпеки для студентів відділень i факультетів філології, журналістики та права; організацію науково-практичних конференцій, нарад і семінарів з питань теорії і практики експертиз та проблем лінгвістичної безпеки. Як бачимо, мовні питання та проблеми лінгвістичної експертизи останнім часом виходять далеко за межі юридичної казуїстики, набуваючи глобальних вимірів, пов'язаних 3 історичними долями соціальних спільнот, етносів і держав.

Зазначимо, що поняття мовної безпеки як різновиду інформаційної безпеки було запропоноване В. А. Широковим ще в 1995 році при розробленні досі не затвердженої Концепції інформаційної безпеки України. У цьому зв’язку зробимо кілька зауважень загального характеру, пов'язаних із питаннями функціонування мови в сучасному українському суспільстві. Українська мова - національне надбання, у якому не тільки яскраво відображаються наші чесноти, а й вади. Українська мова в сучасному суспільстві, на жаль, перетворюється на інструмент свідомих (а тому й аморальних), а також і несвідомих (хоч від цього й не легше) порушень етичних норм і традицій українського етносу, цивільного та карного законодавства, закріплених (бодай частково) навіть у статтях відповідних кодексів. Дехто пояснює, що якщо хворіють суспільство й держава, то хворіє i мова. Безперечно, це так, але ми хотіли б відзначити дещо інший аспект сучасної мовно-суспільної ситуації, а саме - намагання використати механізми мови для досягнення певних цілей (у тому числі - політичних). На наше переконання, така практика повинна одержати правову оцінку та законодавчу регламентацію, оскільки застосування зазначених механізмів без обмежень може призвести до фатальних для народу та держави наслідків. Безконтрольна й безкарна експлуатація індивідуальної та колективної мовної свідомості й підсвідомості громадян малює невтішну перспективу не лише для громадянського, а й, будучи втіленою у високоефективні технології, - людського суспільства взагалі. На зміну чи на додаток до ядерної, екологічної та інших загроз може прийти загроза лінгвістична, а 3 нею й новий різновид зброї масового знищення етносів лінгвістична зброя. 


\subsection{1. Лінгвістична та судова лінгвістична експертизи: подібності та відмінності}

Судова лінгвістична експертиза $є$ різновидом загальної лінгвістичної експертизи, отже вони мають багато спільних рис. Проте, між ними є й суттєві відмінності, що унаочнено у наведеній нижче таблиці.

\begin{tabular}{|c|c|}
\hline Судова лінгвістична експертиза & Лінгвістична експертиза \\
\hline $\begin{array}{l}\text { Завжди пов’язана з юриспруденцією } \\
\text { (право- і судочинством). }\end{array}$ & $\begin{array}{l}\text { За висновком лінгвістичної експертизи не } \\
\text { завжди передбачається судовий розгляд } \\
\text { (наприклад, лінгвістичні експертизи } \\
\text { історичних писемних або літературних } \\
\text { джерел). }\end{array}$ \\
\hline $\begin{array}{l}€ \text { процесуально регламентованим } \\
\text { науковим лінгвістичним дослідженням } \\
\text { усного і письмового тексту на предмет } \\
\text { установлення фактів, які є предметом } \\
\text { юридичного розгляду. }\end{array}$ & $\begin{array}{l}\text { Є науковим дослідженням } \\
\text { природномовних текстів на предмет } \\
\text { встановлення фактів щодо їхньої якості, } \\
\text { змісту, обставин створення та } \\
\text { особливостей функціонування тощо. }\end{array}$ \\
\hline \multicolumn{2}{|c|}{ Об’єкт лінгвоекспертного дослідження } \\
\hline $\begin{array}{l}\text { Текст - носій фактів, що мають значення } \\
\text { для юридичного розгляду. }\end{array}$ & Будь-який природномовний текст або об’єкт. \\
\hline \multicolumn{2}{|c|}{ Предмет лінгвоекспертного дослідження } \\
\hline \multicolumn{2}{|c|}{$\begin{array}{l}\text { Факти, пов’язані з обставинами створення та функціонування об’єкта лінгвоекспертно-го } \\
\text { дослідження. }\end{array}$} \\
\hline \multicolumn{2}{|c|}{ Нормативно-правова база } \\
\hline 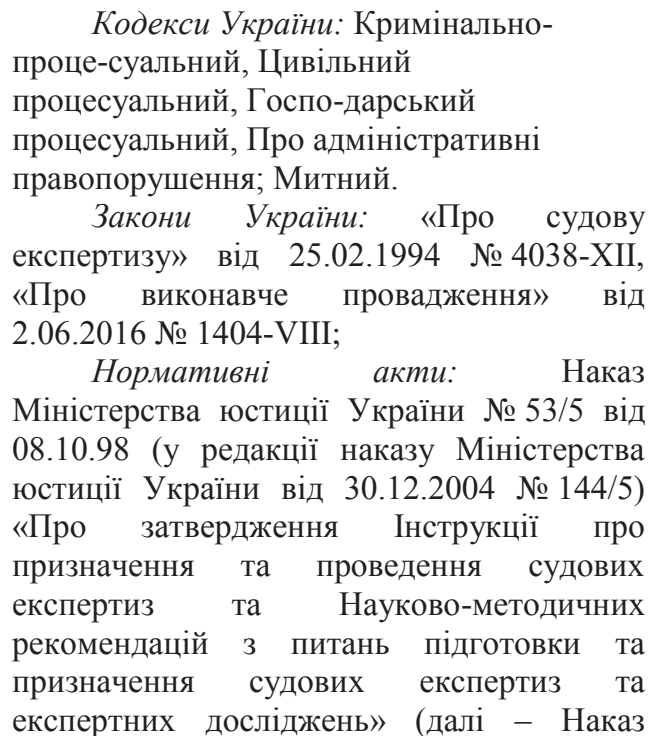 & $\begin{array}{l}\text { В Україні досі не розроблено спеціальної } \\
\text { нормативно-правової бази, яка б } \\
\text { регламентувала процеси } \\
\text { лінгвістичної експертизи. }\end{array}$ \\
\hline
\end{tabular}


№ 53/5).

\section{Ініціатори (замовники)}

Учасники судових процесів (судові та слідчі органи, адвокатура і т. ін.).

Будь-які зацікавлені фізичні або юридичні особи, в т.ч. учасники судових процесів.

\section{Класифікаційний статус}

Офіційна.

Ініціативна (офіційна та неофіційна).

\section{Виконавці лінгвістичних експертиз}

Науково-дослідні підрозділи судових експертиз Міністерства юстиції України, наукові підрозділи НАНУ, НАПНУ, НАПрНУ, МОНУ.
Державні та приватні експертні заклади, наукові установи, суспільні організації, інші об'єднання, приватні експерти.

\begin{tabular}{|c|c|}
\hline \multicolumn{2}{|c|}{ Експерти } \\
\hline $\begin{array}{l}\text { Фахівці з кваліфікацією судового експерта } \\
\text { зі спеціальності «Дослідження писемного } \\
\text { мовлення», внесені до Державного реєст-ру } \\
\text { атестованих судових експертів (пп. } 1.8 \\
\text { Науково-методичних рекомендацій, зат- } \\
\text { верджених Наказом № 53/5). }\end{array}$ & $\begin{array}{l}\text { Експерти повинні бути } \text { фахівцями } 3 \\
\text { відповідних галузей знань. }\end{array}$ \\
\hline \multicolumn{2}{|c|}{ Права, обов'язки та відповідальність експертів } \\
\hline \multicolumn{2}{|c|}{$\begin{array}{l}\text { Експерти мають усі права, обов’язки та гарантії, а також несуть відповідальність нарівні } 3 \\
\text { атестованими судовими експертами. }\end{array}$} \\
\hline \multicolumn{2}{|c|}{ Порядок призначення } \\
\hline $\begin{array}{l}\text { На основі процесуального акту - поста- } \\
\text { нови слідчого, судді чи за рішенням суду. }\end{array}$ & $\begin{array}{l}\text { У разі залучення до процесуальних дій - } \\
\text { постановою слідчого, рішенням суду. В } \\
\text { несудових експертизах порядок призначення } \\
\text { експертизи не регламентовано. }\end{array}$ \\
\hline \multicolumn{2}{|c|}{ Термін проведення } \\
\hline $\begin{array}{l}\text { Встановлюється залежно від складності } \\
\text { дослідження з урахуванням експертного } \\
\text { на-вантаження фахівців експертної } \\
\text { установи: } \\
10 \text { календарних днів - щодо матеріалів із } \\
\text { невеликою кількістю об’єктів та вирішува- } \\
\text { них питань і простих за характером дослід- } \\
\text { жень; } \\
30 \text { календарних днів - щодо матеріалів із } \\
\text { середньюю кількістю об’єктів та вирішува- } \\
\text { них питань або середньої складності за ха- } \\
\text { рактером досліджень; }\end{array}$ & $\begin{array}{l}\text { Необхідний для проведення об’єктивного та } \\
\text { грунтовного експертного дослідження. }\end{array}$ \\
\hline
\end{tabular}


60 календарних днів - щодо матеріалів із великою кількістю об'єктів та вирішуваних питань;

понад 60 календарних днів - щодо особливо складних за характером досліджень; понад 90 календарних днів - у разі комплексної експертизи із залученням фахів-ців з інших установ;

Більший розумний строк установлюється за письмовою домовленістю з органом (особою), що призначи(в)ла експертизу.

(п. 1.13. Науково-методичних рекомендацій, затверджених Наказом № 53/5).

\section{Основні види}

1) почеркознавча; 2) авторознавча; 3) технічна (пп. 1.2.1 Науково-методичних рекомендацій, затверджених Наказом № 53/5).

\section{Оформлення результатів експертизи}

Висновок експерта - оформлений у відповід-ності до встановленого зразка докладний опис проведених досліджень, зроблених ви-сновків та обгрунтованих відповідей на сформульовані ініціатором проведення пи-тання (Ст. 66 Цивільноправового кодексу України; Ст. 98 Господарсько-процесуаль-ного кодексу України, п. 4 Науково-методич-них рекомендацій, затверджених Наказом № 53/5).
Висновок експертизи - аргументована письмова відповідь на винесені на експертний розгляд питання 3 поясненнями щодо ходу дослідження.

Висновок експертизи (експерта) як джерело доказів у судочинстві

Є одним з основних.

Може визнаватися правомірним доказом лише за рішенням компетентних органів.

\section{Значимість}

Звернення до експертів дозволяє скласти уявлення про перспективність справи в суді.

Висновок лінгвістичної експертизи є дієвим інструментом формування правової позиції у судовому спорі.

\section{Оріснтовний перелік вирішуваних лінгвістичною експертизою питань}

- Чи є певна особа автором наданого на дослідження тексту?

- Чи є певна особа автором декількох різних текстів?

- Чи є автор та виконавець тексту однією або різними особами?

- Чи складений наданий на дослідження текст кількома авторами?

- Які риси соціально-демографічного портрету автора (місце формування мовленнєвих навичок, рідна мова, освіта, стать, вік тощо), можна встановити за наданим на дослідження текстом? 
- Які риси психологічного портрету автора проявлені в тексті?

- Чи спостерігаються в наданому на дослідження тексті ознаки, які можуть свідчити про незвичний психофізіологічний стан автора?

- Чи створений текст під диктовку або шляхом переписування?

- Чи створений текст із навмисним перекручуванням писемного мовлення?

- Чи містять висловлювання автора негативну або позитивну оцінку конкретної особи та іiі діяльності?

- Які значення мають слова, словосполучення, фрази у тексті?

та інші питання (п. 21 Науково-методичних рекомендацій, затверджених Наказом № 53/5).

\section{Методи дослідження}

Загальні: спостереження, експеримент, гіпотеза, аналіз, синтез, індуктивний, дедуктивний, компаративний та ін.

Cпеціальні (визначаються вирішуваними завданнями): структурний, функціональний, контекстний, прагматичний, конструктивний, семантичний, статистичний, дискурсивний, когнітивний та інші види аналізу; ідеалізація, формалізація, моделювання.

\section{Обмеження на проведення (підстава для відмови в проведенні)}

\begin{tabular}{l|l|}
\hline 1) Текст одержаний 3 порушенням & Не визначені \\
встановленого законом порядку. & \\
2) Для авторознавчої судової лінгвістич-ної & \\
експертизи: & \\
- вільні зразки писемного мовлення на & \\
дослідження надано в обсязі, меншому, ніж & \\
25 стандартних сторінок; & \\
- вільні та експериментальні зразки & \\
виконані іншою мовою, ніж досліджуваний & \\
текст через істотну різницю синтаксичних, & \\
лексико-фразеологічних, & стилістичних \\
елементів і структур в різних мовах; \\
- особа, що підлягає ідентифікації та від \\
якої мають відбиратися експеримен-тальні \\
зразки, недосяжна; \\
- якщо обсяг окремого експеримента- \\
льного зразка є меншим мінімально вста- \\
новленого в 500 слів, а загальний обсяг \\
експериментальних зразків - меншим ніж \\
25 сторінок без можливості його збільшен- \\
ня (п. 19; п. 21 Науково-методичних реко- \\
мендацій, затверджених Наказом № 53/5).
\end{tabular}

\section{3. Сучасний стан розвитку галузі лінгвістичних експертиз}

Світова та вітчизняна практика лінгвістичних експертиз неухильно зростає, що вимагає систематичного моніторингу досягнень цієї галузі 3 метою узагальнення застосованих методів та методик, моделювання предмета дослідження для його ідентифікації комп’ютерними засобами. 


\subsection{1. Психолінгвістична судова експертиза}

Психолінгвістична судова експертиза $є$ комплексним дослідженням, що грунтується на об'єктивно встановленому факті відображення в тексті психічного та / або психофізіологічного стану його автора. Цей різновид лінгвістичної експертизи призначається за рішенням суду або слідчими органами. Ї̈ї об'єктом є тексти, створені за юридично значимих обставин чи створення яких ці обставини за собою тягне. Предметом є риси особистості, психічний, психофізіологічний, емоційний стан автора тексту, призначеного на експертний розгляд.

Одним із різновидів текстів, з якими працюють експерти-психолінгвісти, $\epsilon$ записки самогубців (за приблизними оцінками, останні комунікативні акти фіксують від 15 до 40 \% осіб). На основі аналізу тем, адресатів та висловлених емоцій тисяч передсмертних листів експерти-суїцидологи встановили типові мотиви самогубств: 1) уникнення провини, покарання, страждань; 2) протест (помста); 3) самопокарання; 4) примус; 5) раціональна відмова; 6) волання про допомогу. Ці знання мають велике значення для розкриття кримінальних злочинів, що маскують вбивство під самогубство та для вирішення проблеми попередження самогубств.

Методика проведення психолінгвістичних експертиз на широкий загал не виноситься, на відміну від експертних висновків у резонансних справах. Так, завдяки спільним зусиллям експертів балістиків та психолінгвістів Всеросійського НДІ судових експертиз Міністерства юстиції РФ у грудні 1991 р. було поставлено крапку в розслідуванні кримінальної справи № $02-29.1930$ p. «Про самогубство Володимира Володимировича Маяковського», розпочатої 14 квітня 1930 р. Експерти-психолінгвісти, за результатами аналізу передсмертного листа В. В. Маяковського, датованого 12 квітня 1930 р. (за дві доби до фатального пострілу), дійшли висновку, що автором цього листа був сам поет, який створив його у стані сильного нервового збудження від усвідомлення того, що вирішив здійснити. ${ }^{179}$

Очевидно, що для підвищення достовірності висновків психолінгвістична судова експертиза має спиратись на результати відповідних наукових досліджень. Приклад такого роду досліджень наведено в журналі «Де-юре. SMART-ЖУРНАЛ для юристов и про юристов» у публікації від 6 червня 2018 р. під назвою «Депрессия «говорит» на своем языке» ${ }^{180}$.

У вказаній публікації йдеться про лінгвістичні технології діагностування депресії - небезпечного психологічного стану, від якого потерпають сотні

${ }^{179}$ Цит. за публікацією проф. судової медицини судмедексперта О. Маслова «Маяковский. Тайна смерти: точка над і поставлена» Novaya Gazeta.RU. № 68 от 16 сентября 2002 г.

1803 посиланням на публікацію «People with depression use language differently - here's how to spot it» у журналі Clinical Psychological Science за авторством Mohammed Al-Mosaiwi, PhD, Candidate in Psychology (University of Reading). 
мільйонів людей в усьому світі. Депресія має наслідком погіршення здоров'я, психічні розлади, зниження якості життя, а в важких випадках спричиняє суїцидальну ідеацію (нав'язливі думки про самогубство).

Для з'ясування особливостей мовленнєвої поведінки осіб, що перебувають у депресивному стані, дослідниками було зібрано базу постів (записів) на онлайнфорумах суїцидальної тематики та застосовано для iï опрацювання спеціально розроблені в рамках цього дослідження програмні інструменти. За інформацією дослідників, загалом опрацьовано записи 6400 осіб на 64 веб-ресурсах.

У результаті було встановлено клас слів, наявність яких у текстах із прийнятною точністю дозволяє діагностувати депресивний стан. Так, з'ясувалося, що особи, які перебувають в депресивному стані, вживають відносно багато прикметників та прислівників, що позначають негативні емоції (одинокий, нещзасний, сумно, важкк), а їхнє мовлення характеризується збільшеною кількістю «слів-абсолютів» (завжди, ніколи, нікуди, повністю) та особових та присвійних займенників (я, мені, мене, мій,..), що свідчить про зосередженість цих осіб на відповідних проблемах.

Результати досліджень використано для розроблення алгоритмів програм, здатних до самонавчання. На думку дослідників, точність кваліфікації стану психічного здоров'я на основі зразків тексту, виконана комп'ютером, подекуди навіть перевищує точність висновків кваліфікованих психотерапевтів, а зі збільшенням обсягу бази даних та вдосконаленням алгоритмів, комп'ютер може стати інструментом діагностування й інших психологічних проблем (перфекціонізм, низька самооцінка, соціофобія та ін.).

\subsection{2. Лінгвістична судова експертиза в репутаційних справах}

Зазначений різновид лінгвістичної експертизи призначається судом або може бути ініційований учасниками судового процесу (позивачами, відповідачами, третіми особами, прокурорами та ін.) у зв'язку із розглядом справ про захист честі, гідності та ділової репутації.

Основним методом зазначеної експертизи $\epsilon$ семантичний аналіз, інструментами - академічні тлумачні словники та словники субстандартної лексики.

Експертиза в репутаційних справах полягає у встановленні в аналізованому тексті мовленнєвих маркерів наміру, що свідчать про навмисний характер образи, а також іiі діагностувальних ознак - лексичних та фразеологічних конструкцій, що мають або набувають в контекстах образливого, принизливого характеру по відношенню до певної особи. До них належать: слова, що позначають соціально засуджувані поведінку, діяльність або дії; слова з негативною семантикою, що позначають суспільно неприйнятні переконання; зоосемантичні метафори; слова, що 
виражають негативну оцінку вчинків особи, іiі особистості; евфемізми; табуйована лексика (лайка) $)^{181}$, а також фальшиві негативні відомості про особу та ін.

Крім цього, лінгвісти-експерти мають визначити: комунікативний статус висловлювання (порушення мовленнєвого етикету чи образа), віднесеність негативних тверджень до конкретної особи; використані стилістичні засоби (гіпербола, алегорія, сатира, іронія, протиставлення, алюзія та ін.), характер (форму подання) негативних відомостей (фактологічний або оцінний); за можливості - характер їхнього розповсюдження (публічний або приватний); порушення яких саме законів чи моральних норм приписано особі; комунікативні наміри автора та ін.

\subsection{3. Семантична лінгвістична експертиза}

Цей різновид лінгвістичної експертизи є одним з найбільш запитаним. До експертів звертаються із запитами щодо тлумачення не лише окремого слова або висловлювання, а й положень ділових документів (угод, контрактів, постанов, ...), нормативних актів (стандартів, правил, норм, положень, інструкцій, рекомендацій, переліків тощо).

Експертиза на предмет тлумачення смислу (або змісту) може виступати окремим дослідженням або етапом більшої за масштабами лінгвістичної експертизи - наприклад, такої, що призначається в репутаційних справах.

Інструментом зазначеного різновиду лінгвістичної експертизи є академічні та інші авторитетні тлумачні словники.

Відзначимо внесок у розвиток теорії та практики семантичних експертиз Українського бюро лінгвістичних експертиз НАН України, матеріали експертного дослідження якого використано в цьому інформаційному блоці.

30 серпня 2018 р. на офіційному сайті фракції партії «Блок Петра Порошенка» (URL: http://solydarnist.org/?p=188230) було оприлюднено заяву 3 приводу призначення нового керівництва телеканалу NewsOne, в якій спрямованість цього телеканалу називалась «антидержавною», а призначення його керуючим А. В. Портнова - колишнього радника президента України В. Ф. Януковича та заступника глави президентської адміністрації, на думку депутатів фракції - авторів заяви, є остаточним доказом перетворення телеканалу «на частину пропагандистської машини Кремля»: «Передача українського телеканалу в руки втікача, соратника Януковича, який підозрюється у причетності до злочинів проти учасників Революції Гідності, окупації Криму та у державній

${ }^{181}$ Цена слова: Из практики лингвистических экспертиз текстов СМИ в судебных процессах по искам о защите чести, достоинства и деловой репутации / Под ред. М. В. Горбаневского. Москва: Галерия, 2001. 184 с. 
зраді - ставить під загрозу національну безпеку України, невід'ємною частиною якої є інформаційна безпека».

У відповідь А. В. Портнов подав судовий позов проти партії «Блок Петра Порошенка» на предмет визнання недостовірною заяви про підозру в його причетності до злочинів, що кваліфікуються як державна зрада, й публічного іiі спростування.

Відповідач замовив у ДП «Українське бюро лінгвістичних експертиз НАН України» експертизу, що мала відповісти на питання: «Чи надає текст заяви фракції партії «Блок Петра Порошенка» лінгвістичні підстави стверджувати, що інформація, представлена у висловлюванні «який підозрюється у причетності до злочинів проти учасників Революції Гідності, окупації Криму та у державній зраді», стосується А. В. Портнова?». Відповідь експерта - д. філол. н. Б. М. Ажнюка була однозначною - зміст підрядного означального речення «який підозрюється у причетності до злочинів проти учасників Революції Гідності, окупації Криму та у державній зраді» актуалізує зв'язок цього текстового сегмента саме 3 прізвищем «Янукович». А, відтак, підстав стверджувати, що це висловлювання стосується Андрія Портнова, немає. Цей експертний висновок послугував основою заперечень, наданих суду партією «Блок Петра Порошенка» 182

\subsection{4. Лінгвістична експертиза в справах щодо введення в оману}

Об'єктом цього різновиду лінгвістичної експертизи є рекламні тексти, написи на етикетках, листівках, інструкції до промислових товарів, медичних препаратів, технічні регламенти та ін. Предметом - спосіб викладення та формулювання, що уможливлюють замовчування, подання неправдивих, неточних та неповних відомостей (Ст. 15-1 Закону України «Про захист від недобросовісної конкуренції» від 7.06.1996 № 236/96-ВР).

Введення в оману, що має метою одержання неправомірної переваги в конкуренції, є поширеним прийомом не лише недоброчесних виробників чи реалізаторів, а й політичних маніпуляторів, які через дискредитацію своїх опонентів (конкурентів) впливають на електоральну поведінку громадян, у такий спосіб усуваючи опонентів із політичної арени або послабляючи їхній вплив на політичні процеси. Негативна інформація в політичному протистоянні не може подаватись у непристойній формі або мати дифамаційний характер - за це законодавством передбачена відповідальність, тому в такого роду текстах інформація подається непрямо, імпліцитно, завуальовано, пов'язується з певною особою дистантно, через контекстуальні, інтертекстуальні, конотаційні зв'язки. Розгляд у судових інстанціях справ щодо введення в оману із застосуванням

${ }^{182}$ URL: https://zib.com.ua/files/zaperechennia bpp portnov.pdf. 
лінгвістичних засобів та прийомів базується на висновках експертів-лінгвістів. Ураховуючи масштаби рекламних кампаній та хитромудрі «макіавеллівські» методи їх ведення, цей різновид лінгвістичної експертизи у вітчизняних реаліях ще довго не втратить своєї актуальності та значимості.

\subsection{5. Логіко-лінгвістична експертиза}

Метою логіко-лінгвістичної експертизи є перевірка тексту на мовну, змістову та логічну коректність. Цей різновид лінгвістичної експертизи, що передбачає визначення відповідності аналізованого тексту літературним нормам, стилістичним вимогам та законам логіки, може виступати окремим дослідженням або етапом більшої за масштабами експертизи (наприклад, психолінгвістичної чи авторознавчої, якщо вимагається оцінити рівень (розвиненість) мовленнєвих навичок автора або ступінь професійного редакторського втручання в аналізований текст). Вплив редактора на авторську індивідуальність, взагалі, є об'єктивним і загальновідомим фактом. Проте оцінити міру втручання редактора в текст без верифікованих зразків інших текстів цього ж автора, або визначити, чи спричиняє редагування спотворення логіки викладу оригінального тексту можливо лише за непрямими ознаками, що індивідуалізують манеру письма (до таких належать, зокрема, помилки писемної комунікації або специфічні мовні конструкції).

\subsection{6. Лінгвістична експертиза законопроєктів}

Лінгвістична експертиза законопроєктів - це визначення відповідності тексту законопроєктів правописним та стилістичним нормам літературної української мови, канонам офіційно-ділового стилю (вимогам щодо структури, побудови та оформлення), вимогам логічної коректності (уніфікованість терміносистеми, відсутність логічних конфліктів тощо).

У межах лінгвістичної експертизи законопроєктів також передбачається надання рекомендацій 3 усунення виявлених недоліків та помилок (орфографічних, синтаксичних, стилістичних, логічних, технічних, термінологічних та ін.).

Лінгвістична експертиза кожного законопроєкту ініціюється відповідним суб'єктом законотворчого процесу. Основна робота лінгвістів-експертів відбувається перед другим читанням, після чого текст законопроєкту підлягає лише редакційному опрацюванню.

У 2007 р. Український мовно-інформаційний фонд НАН України на замовлення Міністерства фінансів України проводив лінгвістичні експертизи трьох редакцій проєкту Податкового кодексу України (попередньої, першої та другої). 
За результатами лінгвістичної експертизи текст попередньої редакції Податкового кодексу України було визнано мовно некоректним та логічно неузгодженим. Разом із вичерпним описом виявлених помилок писемної комунікації (загалом їх було встановлено близько тисячі) науковцями Фонду було надано аргументовані рекомендації розробнику з їх усунення та запропоновано стилістично коректні варіанти формулювань.

Лінгвістична експертиза другої редакції Податкового кодексу полягала в більш глибокому опрацюванні втіленого в мовній формі змісту. Третьої - в узагальненні результатів першої та другої редакції.

\subsection{7. Авторознавча експертиза}

Метою авторознавчої (інша назва - атрибуційна, від лат. attributionis приписування) експертизи є ідентифікація автора тексту. Прикладну значимість авторознавчих експертиз важко недооцінити: через них вдавалося викривати не лише недоброчесних авторів, а й розкривати кримінальні злочини та навіть загадки історії.

Атрибуційна експертиза вважається завершеною тоді, коли іiі висновки вказують на конкретну особу як на найбільш імовірного автора тексту або на причини, через які атрибування неможливе.

На вибір методів атрибуційного дослідження впливають вихідні умови, 3 яких мають виходити експерти - наявність / відсутність гіпотези щодо авторства та зразків тексту гаданого автора.

Поширені питання лінгвістичної авторознавчої експертизи: Чи є певна особа (наприклад, титульний, зазначений на обкладинці автор) фактичним автором аналізованого тексту (або текстів)? Чи є аналізований текст одноосібним? Чи має місце в аналізованому тексті імітація (стилізація) мовлення іншої особи? Який авторський внесок кожної особи, що брала участь у створенні тексту? Яка міра редакторської роботи над аналізованим текстом? Та інші.

Основними інструментами авторознавчих експертиз $є$ синтаксичний, семантичний та статистичний аналізи. Будь-які інші інструменти є деякою їхньою модифікацією або комбінацією. Синтаксичний аналіз дозволяє порівнювати еталонний та аналізований тексти за синтаксичною складністю (наприклад, середньою довжиною речень, абзаців), семантичний - оцінювати семантичну подібність, статистичний - порівнювати тексти за формальними характеристиками (наприклад, обсягом словника, кількістю та співвідношенням частин мови, повнозначних та службових слів та ін). Вважається, що індивідуальність стилю визначається унікальним набором значень формальних характеристик, які, відповідно до стохастичної моделі породження мовлення, $\epsilon$ стійкими (стабільно повторюваними) у текстах статистично значущої довжини. 
Як зазначалось, ключовою передумовою авторознавчих експертиз $\epsilon$ сформульована на екстралінгвістичних засадах гіпотеза щодо авторства. У разі іiі відсутності та відсутності еталонних зразків тексту гаданого автора, робота експертів істотно ускладнюється, а результат експертизи може бути неочевидним (спірним).

Декілька ілюстрацій на підтвердження значущості гіпотези щодо авторства в авторознавчих експертизах.

1) Влітку 2018 р. газета «Нью-Йорк Таймс» оприлюднила анонімну статтю особи, що назвала себе «високопосадовцем адміністрації президента США», в якій ішлося про рух спротиву всередині адміністрації, зусиллями учасників якого стримувались найбільш небезпечні та імпульсивні вчинки Д. Трампа. Стаття викликала широкий резонанс, а авторознавча експертиза, як вид дослідження, що мав би задовольнити суспільний інтерес 3 приводу особи анонімного автора в науковий спосіб, раптово опинилась у фокусі уваги мас-медіа. Але експерти пояснили, що зусилля, яких треба докласти для «сенсаційного» викриття, не варті результату: для ідентифікації аноніма необхідно мати в розпорядженні зразки текстів усіх можливих підозрюваних (на думку політологів, це приблизно 50 осіб, й не факт, що серед них $є$ розшукуваний автор), причому того ж жанру, що й анонімний лист.

2) У 1995 р. до редакції декількох періодичних видань США надійшов анонімний текст, озаглавлений як «Маніфест «Індустріальне суспільство та його майбутнє»», з якого випливало, що його автором $є$ терорист-одинак. Після публікації «Маніфесту» в газеті «Нью-Йорк Таймс» до ФБР звернувся якийсь Девід Качинський $з$ підозрою, що автором цього маніфесту може бути його психічно нездоровий молодший брат Теодор. Порівняльний аналіз тексту «Маніфесту» 3 наданими Д. Качинським листами його брата тривав чотири місяці та мав однозначну відповідь - автором «Маніфесту» та листів є та сама особа. Обшук помешкання підозрюваного підтвердив висновки експертизи співробітники ФБР знайшли оригінал «Маніфесту» та компоненти саморобних бомб.

3) У 2013 р. неофіційне джерело повідомило, що фактичним автором книги Р. Гелбрейта «Зов зозулі» (The Cuckoo's Calling) є Д. Роулінг, авторка серії книг про Гаррі Поттера. Для перевірки цієї інформації був залучений фахівець у галузі інформатики та лінгвістики П. Юола 3 Duquense University (США), який у програмний спосіб виконав порівняння спірного тексту та декількох романів письменниці. Результати підтвердили авторство Д. Роулінг, що вона, до речі, одразу визнала після оприлюднення результатів дослідження.

4) У 2017 р. до Українського мовно-інформаційного фонду НАН України звернувся Департамент спеціальних розслідувань Генеральної прокуратури України із запитом на проведення авторознавчого дослідження рукопису, 
перекладеного англійською. Експертне дослідження пропонувалось проводити за умов неповноти інформації, оскільки верифікованих зразків писемного мовлення репрезентативного обсягу особи, одноосібне авторство якої мали довести або спростувати науковці Фонду, не було навіть у розпорядженні Генеральної прокуратури України, а текст рукопису піддавався подвійному літературному редагуванню - російською мовою та при перекладі - англійською. В практиці авторознавчих експертиз таке завдання вважається завданням найвищої складності. ${ }^{183}$ Безпрецедентне за масштабами та кількістю виконаних досліджень авторознавче дослідження тривало майже рік. Результати дослідження захищені таємницею слідства, що триває досі, тому зазначимо, що відповідь на поставлене перед експертами питання грунтується на результатах формально-змістовного, джерельного, компаративного, логіко-лінгвістичного, тематичного, стилістичного, семантичного, дискурсивного, контекстного, хронологічного, фактологічного та статистичного аналізів. Обсяг висновку за результатами проведеного авторознавчого дослідження (241 стор.) зіставний 3 обсягом аналізованого тексту (210 стор.), а сумарний обсяг 11 Додатків (1656 стор.) перевищив обсяг аналізованого тексту майже в вісім разів.

\subsection{8. Лінгвістична експертиза на ознаки недоброчесного запозичення (плагіату)}

Недоброчесне запозичення або плагіат - це відтворення опублікованих текстів інших авторів без відповідного посилання (Ст. 69 Закону України «Про вищу освіту» від 01.07.2014 №1556-VII). Але через міжгалузеву омонімію (в галузі захисту авторських прав поняття «плагіат» пов'язується 3 незаконним використанням об'єктів права інтелектуальної власності, що порушує авторські права, у тому числі й майнові), науковці Фонду намагаються його уникати в висновках.

Розвиток інформаційно-комунікаційних технологій загострив проблему недоброчесних запозичень з вебу, а розвиток технологій онлайн-перекладу зробив веб майже неосяжним полем діяльності компіляторів. Зауважимо, що від «випадкового» (ненавмисного) запозичення кількох речень не «застрахований» жоден автор через ефект «споріднення 3 думкою іншого», тоді як обсяг навмисного запозичення може сягати сотень сторінок (у монографіях, дисертаціях, звітах про науково-дослідні роботи тощо). Завдання експертів розмежувати й кількісно оцінити обсяги власне авторського та запозиченого тексту.

${ }^{183}$ Баранов А. Н. Лингвистическая экспертиза текста: теория и практика: учеб. пос. / А. Н. Баранов. 2-е изд. Москва: Флинта: Наука. 2009. 
У 2017 р. до Українського мовно-інформаційного фонду НАН України звернувся представник Всеукраїнської громадської організації «Українська федерація вчених» член-кореспондент НАН України професор В. Л. Мазур із запитом на проведення лінгвістичної експертизи дисертаційної роботи на здобуття наукового ступеня доктора педагогічних наук К. М. Кириленко «Теоретичні і методичні основи формування інноваційної культури майбутніх культурологів у вищому навчальному закладі», захищеної 15 жовтня 2015 р. на засіданні спеціалізованої вченої ради Д 26.004.18 Національного університету біоресурсів і природокористування України зі спеціальності 13.00 .04 - теорія і методика професійної освіти.

На експертний розгляд було винесено питання: 1) щодо відповідності мовного та стилістичного оформлення наданої на дослідження дисертації вимогам, встановленим Міністерством освіти та науки України до дисертацій на здобуття наукового звання доктора наук; 2) щодо запозичення в тексті дисертації матеріалів інших авторів без посилання на джерела (у разі стверджувальної відповіді, від експертів (науковиів Фонду) вимагалося зазначити відсоток (частку) запозиченого тексту).

Експертиза дисертації К. М. Кириленко включала логіко-лінгвістичну експертизу як етап. За іiі результатами експерти встановили надмір російських лексичних та синтаксичних кальок (т. зв. росіянізмів), тому пошук джерел запозичень проводився також i в російськомовному вебі. Для цього кожне речення основного тексту аналізованої дисертації було перекладено російською та надіслано на пошукові системи.

Частка запозиченого тексту обчислювалась як відношення кількості речень, визначених запозиченими, до загальної кількості речень основного тексту дисертації.

За результатами проведеної лінгвістичної експертизи тексту дисертації К. М. Кириленко встановлено, що:

— загальний рівень літературного опрацювання тексту є низьким;

- текст дисертації не відповідає вимогам стислості, точності, логічності викладу, аргументованості; насичений бездоказовими та беззмістовними твердженнями;

- посилання та список використаних джерел не утворюють систему через високий вміст некоректних та сфальсифікованих посилань (загалом таких встановлено 313 з 474 згідно зі списком літератури);

- щонайменше 30 \% тексту є скопійованим матеріалом інших авторів без посилання на джерела (тобто недоброчесним запозиченням).

За сукупністю ознак, зокрема 30 \% від основного тексту недоброчесних запозичень із праць інших авторів та 3 урахуванням низького рівня мовного та стилістичного оформлення, дисертацію К. М. Кириленко було визнано такою, що 
не відповідає вимогам Міністерства освіти та науки України до дисертацій на здобуття наукового звання доктора наук. ${ }^{184}$

\subsection{9. Лінгвістична експертиза на предмет пропагування наркотиків}

У 2011 р. до Українського мовно-інформаційного фонду НАН України звернулась Національна експертна комісія України з питань захисту суспільної моралі 3 запитом на проведення лінгвістичної експертизи на предмет пропагування наркотиків. Об'єктом експертизи виступила назва розважального закладу «COCAINE» (м. Київ).

На експертний розгляд було винесено питання стосовно значення, в якому вжито слово «кокаїн» у назві розважального закладу.

За результатами проведеного дослідження встановлено, що слово «кокаїн» у назві розважального закладу не асоціюється з наркотиком або чимось злочинним. «Завдяки» мас-медіа слово «кокаїн» 3 табуйованого перетворилось на синонім життєвого успіху та шикарного («зіркового») життя. Саме в такому значенні вжито слово «кокаїн» в аналізованій назві. Очевидно, що власник в такий спосіб розраховував підвищити популярність закладу, не маючи на меті пропагування наркотику. Проте науковці Фонду рекомендували прибрати назву наркотику 3 назви розважального закладу, що, наскільки нам відомо, було враховано.

Зазначимо, що для забезпечення належної об’єктивності висновку, науковцями Фонду, крім аналізу всіх значень (прямого, непрямих, фразеологічних, контекстних) слова «кокаїн», було переглянуто до сотні тисяч веб-сторінок з різномовних секторів Інтернету, що містили це слово як власну назву або як іiі складник, з метою визначення рівню толерантності мовленнєвої

${ }^{184}$ Про це див. публікації:

Доктор Плагиат. Академическая экспертиза докторской диссертации жены вице-премьера показала: плагиат и множество ошибок. Зеркало недели. 2017. 7 квітня. URL: http://gazeta.zn.ua/science/doktor-plagiat-244861 .html;

Эксперты: Докторская диссертация жены вице-премьера Кириленко - плагиат. Інформаційна агениія «Bicmi». 2017. 8 квітня. URL: http://vesti-ukr.com/strana/233698-ekspertydoktorskaja-dissertatsija-zheny-vitse-premera-kirilenko-plahiat;

Докторская диссертация Екатерины Кириленко на 30 \% состоит из плагиата, - экспертное заключение. Інформачійна агенція «Украӥнські новини». 2017. 8 квітня. URL: http://ukranews.com/news/490667-doktorskaya-dyssertacyya-ekateryny-kyrylenko-na-30-sostoyt-yzplagyata-ehkspertnoe-zaklyuchenye;

Научная диссертация жены министра Кириленко на 30 \% - плагиат. Інформаційна агенція ua1. 2017. 9 квітня. URL: om.ua/rus/politics/nauchnaja-dissertatsija-zheny-ministra kirilenko-na-30--plagiat-29512.html;

26 \% диссертации жены Кириленко являются плагиатом, а текст не соответствует уровню докторских работ, - экспертиза. Видання Цензор.HET. 2017. 8 квітня. URL: https//cenor.net.ua; та інші. 
спільноти до теми наркотиків у назвах публічних закладів, товарах масового вжитку, мистецтві, рекламі тощо.

\subsubsection{0. Лінгвістична експертиза на предмет ознак богохульства}

Свобода віросповідання в Україні $є$ конституційно закріпленим правом людини та громадянина (Стаття 35 Конституції України). Предметом зазначеної експертизи $є$ мовна демонстрація зневаги, презирства по відношенню до релігійних святинь, символів, артефактів, обрядів тощо (богохульство), що $є$ неповагою до почуттів віруючих та може призвести до розпалювання релігійної ворожнечі.

У країнах 3 континентальним (романо-германським) типом правової системи, до якої належить i Україна, богохульство розцінюється як адміністративне правопорушення (за винятком особливо цинічних випадків), що карається штрафом, громадськими роботами та обмеженням на обіймання деяких посад. Проте у країнах з правовою системою шаріату богохульство визнається тяжким злочином, який передбачає навіть вищу міру покарання.

Завдання лінгвістів-експертів, що проводять експертизу на предмет ознак богохульства, полягає у встановленні предмета мовлення, міри публічності та навмисності, наявності обсценної, жаргонної та оцінної лексики та фразеології, засобів реалізування іронії, мовленнєвої агресії (знущання, наклеп, образа, аналогія), мовленнєвої маніпуляції та облуди.

\subsubsection{1. Лінгвістична експертиза на предмет прихованих мотивів}

Текст є джерелом інформації не лише про особистість автора, а також про його явні та приховані мотиви (комунікативні наміри, цільове орієнтування), спрямовані на досягнення бажаного авторові стану речей через вплив на реципієнта (читача).

Поширені питання лінгвістичної експертизи на предмет прихованих мотивів: Чи містяться в аналізованому тексті:

- елементи пропаганди (війни, насильства, сепаратизму, масових заворушень, наркотиків, ворожнечі)?

— погрози або заклики до деструктивних дій?

- вислови, спрямовані на розпалювання національної, расової, релігійної ворожнечі та ненависті?

- наклеп, наруга, приниження честі та гідності кого-небудь?

Якими є можливі мотиви складання аналізованого тексту, крім тих, що декларуються? Чи має аналізований текст маніпулятивні властивості? (наприклад, приховану рекламу) та ін. 
Інструментами цього різновиду лінгвістичної експертизи є тлумачні словники; бази даних прецедентів; спеціалізована науково-методична література.

Лінгвістична експертиза на предмет прихованих мотивів набула виключного значення в світі, що здригається від терористичних загроз. Так, наприкінці січня 2019 р. Росією прокотилась хвиля евакуацій, спричинена анонімними листами, розісланими на електронні адреси шкіл, лікарняних закладів, торгівельних центрів, державних установ міст Челябінська, Магнітогорська, Омська, Уфи, в яких попереджалося про можливе замінування цих об’єктів. За результатами дослідження експерти дійшли висновку, що ймовірним автором та розповсюджувачем цих листів $є$ група підлітків, які вирішили «розважитися» у такий спосіб. Висновок було зроблено на підставі численних правописних помилок, властивих підліткам, наборів кліше, відсутності конкретних загроз, вимог. Експерти визначили, що автори не являють реальної загрози, що знизило напруженість у відповідних регіонах. Наразі пошук пранкерів триває. ${ }^{185}$

Лінгвістична експертиза на предмет прихованих мотивів може проводитись як етап авторознавчої або експертизи на предмет образи. У наведеному прикладі приховані мотиви визначалися на основі соціологічного портрету автора. В Українському мовно-інформаційному фонді НАН України розроблено методику визначення прихованих мотивів на основі розподілу ключових слів. Мережа зв'язків ключових слів та в певний спосіб організовані текстові структури (асоціації, «перегукування», порівняння, повтори) формують лейтмотив твору його головну тему. Отже, надвербальні (приховані) смисли та мотиви завжди $є$ співвідносними з окремими лексичними конструкціями, стилістичними засобами та прийомами, формальний опис яких на сьогодні $є$ достатньо розвиненим для здійснення руху від тексту до автора та його мотивів.

Про це та інше більш детально йтиметься в наступному підрозділі.

Наведений короткий огляд, звісно, не охоплює всіх аспектів лінгвоекспертної діяльності. Але його достатньо для розуміння того, що будьякий предмет лінгвістичної експертизи, зафіксований в мові, має мовну «оболонку». Тому лінгвістичні експертизи базуються на знаннях теоретичної лінгвістики, а їхні об’єкти мають досліджуватися інструментами лінгвістики прикладної.

${ }^{185}$ Цит. за публікацією «Похоже на подростков, которые хотели поиграть: разбираем письма «террористов» с лингвистом». 161.RU. Ростов-на-Дону онлайн. 2019. 31 січня. URL: https://161.ru/text/incidents/65901351? 


\section{4. Практичне застосування лінгвістичних корпусів як інструменту лінгвоекспертної діяльності}

Об’єктами сучасної лінгвоекспертної діяльності є не лише окремі слова або висловлювання, а й істотно більші за обсягом тексти (монографії, дисертації, підручники, літературні твори) та навіть текстові масиви (тематичні колекції, бібліотеки). Це орієнтує розвиток галузі лінгвістичних експертиз у двох взаємопов'язаних напрямках: 1) розроблення засад формального опису природномовних феноменів (ефектів, об'єктів, відношень, фактів тощо), що $є$ предметом лінгвоекспертного дослідження; 2) розроблення або адаптування існуючого інструментарію опрацювання великих текстових масивів для вирішення завдань, що постають перед експертами.

Наукові досягнення в першому напрямку дозволяють підвищувати об’єктивність результатів лінгвістичних експертиз через їхню відтворюваність, що можливо лише за умови розроблення та використання достатньо формалізованих процедур лінгвістичного аналізу.

Наукові досягнення в другому напрямку пов’язуються сьогодні, насамперед, iз корпусними технологіями - способами представлення природномовного тексту практично необмеженого обсягу, що уможливлює багатопараметричний пошук та опрацювання значущої для експертизи інформації. Багатопараметричність означає можливість оперування лінгвістичною інформацією у розрізі різних граматичних, синтаксичних, семантичних параметрів та їхніх комбінацій, а також формалізованих параметрів (зокрема, статистичних), що пов’язуються з різними аспектами організації тексту.

Крім потужного пошукового сервісу, застосування корпусних технологій дозволяє автоматизувати окремі ділянки людської мовленнєвої компетенції, зменшити трудомісткість роботи експертів, підвищити оперативність експертного дослідження та коректність вибору й повноту охоплення досліджуваних у рамках лінгвоекспертної діяльності феноменів (як продемонстровано вище, вони $\epsilon$ різними для кожного різновиду лінгвістичної експертизи), що має вирішальний вплив на результати експертизи. Крім того, робота в спільному інформаційному середовищі, застосування єдиної технології опрацювання й представлення даних, забезпечення централізованого зберігання та захисту даних, віртуалізація процесів доступу та взаємодії уможливлює спільну роботу територіально віддалених лінгвістів-експертів.

Для проведення лінгвістичної експертизи аналізований текст разом із текстами, необхідними для дослідження, завантажується до електронної бібліотеки, що структурно входить до лінгвістичного корпусу. Після цього відбувається маркування - приписування текстам та їхнім елементам спеціальних міток різних типів: зовнішнього (складники бібліографічного опису); 
внутрішнього, що експлікують структуру тексту (наприклад, позиція речення в тексті), лінгвістичного (лексикографічні, граматичні, синтаксичні, семантичні та ін.). Завдяки маркуванню користувач набуває можливість прямого доступу до будь-якого контексту.

Які завдання лінгвістичних експертиз наразі вирішуються за допомогою лінгвістичних корпусів? Як саме корпусні технології втілюються в інструментальні комп'ютерні системи підтримки лінгвістичних експертиз? Ці та інші питання є предметом подальшого викладу.

\subsection{1. Корпусні технології в логіко-лінгвістичних експертизах}

В Українському мовно-інформаційному фонді на основі корпусних технологій розроблено інструмент маркування помилок писемної комунікації (ППК), встановлення яких передбачає цей різновид лінгвістичної експертизи. До його основи покладено Рубрикатор - неорієнтований дерев'яний граф, вершинами якого є рубрики - класифікаційні родові узагальнення. У межах кожної рубрики визначено підрубрики - видові узагальнення. Маркування ППК в аналізованому тексті здійснюється виділенням у тексті лексичних або синтаксичних одиниць, що $\epsilon$ «носіями» ППК та присвоєнні їм значень відповідних рубрик/ підрубрик.

Особливість розробленого інструменту маркування ППК полягає в можливості багаторівневого розмічання. Наприклад, слово 3 друкарською чи орфографічною помилкою не підходить за значенням, є частиною некоректної синтаксичної конструкції, що входить до помилково продубльованого фрагменту. Контекст, який містить зазначені помилки, маркується, відповідно, чотирма підрубриками.

Додавання нових об’єктів (рубрик та підрубрик) не потребує перебудови структури Рубрикатора. Відсутність обмежень на кількість рівнів уможливлює детальну класифікацію ППК. Експерт робить запис (коментар) по суті ППК у відповідному полі екранної форми: у такий спосіб відбувається ведення бази даних ППК. Коментар до наступних ППК з тієї самої підрубрики може бути експортованим із БД.

Основний ряд Рубрикатора:

\section{I ТЕХНІЧНІ ПОМИЛКИ}

1.1. Помилкові дублювання

1.2. Пропущене слово

1.3. Помилкове слово

\section{ІІ ФОРМАЛЬНО-ЗМІСТОВІ ПОМИЛКИ}

2.1. Невідповідність заголовка та контенту

2.2. Помилкове посилання

2.3. Неуніфіковане позначення величин, одиниць виміру, часових інтервалів 
2.4. Помилка в маркуванні та позначенні (нумерації) вкладених об’єктів (таблиці, рисунки) або структурних одиниць тексту (глави, параграфи, розділи, статті)

2.5. Помилка цитування

2.5.1. Не зазначене джерело цитати

2.5.2. Підміна конкретного джерела абстрактним

2.5.3. Цитування з вторинного джерела

2.5.4. Відсутній зв'язок цитати з контекстом

2.5.5. Скорочення (усічення) цитати

2.5.6. Інші

2.6. Порушення вимоги пропорційності структурних одиниць

\section{III ПРАВОПИСНІ ПОМИЛКИ}

3.1. Порушення норм евфонії (милозвучності)

3.1.1. Порушення правил чергування у-в

3.1.2. Порушення правил чергування із-3-зо

3.1.3. Порушення правил чергування й $-\mathrm{Ta}-\mathrm{i}$

3.2. Орфографічні помилки

3.2.1. Неправильне закінчення іменників ч.р. род. відм.

3.2.2. Некоректне скорочення

3.2.3. Інші

3.3. Пунктуаційні помилки

3.3.1. Пропущений розділовий знак

3.3.2. Зайвий розділовий знак

3.3.3. Інший розділовий знак

3.3.4. Порушення правил постановки дужок

\section{IV ЛЕКСИЧНІ ПОМИЛКИ}

4.1. Помилка у вживанні службових частин мови

4.2. Росіянізм

4.3. Слово, відсутнє в лексиці

4.4. Слово-паразит

\section{V ТЕРМІНОЛОГІЧНІ ПОМИЛКИ}

5.1. Помилка в терміні

5.1.1. Некоректний термін

5.1.2. Неуніфікований термін

5.1.3.Інші

5.2. Помилка в дефініції

5.2.1. Некоректна дефініція

5.2.2. Відсутність дефініції

5.2.3. Визначення поняття через обсяг

5.2.4. Коло в дефініції

5.2.5. Наведення дефініції не при першому наведенні терміну

5.2.6. Дефініція в дефініції

5.2.7.Інші 


\section{VI СИНТАКСИЧНІ ПОМИЛКИ}

6.1. Порушення відмінкового керування

6.2. Порушений порядок слів (інверсія)

6.3.Порушення дієслівного керування

6.4. Неузгодження в числі частин складного речення

6.5. Російська синтаксична калька

6.6. Неправильна форма іменника в конструкції «числівник + іменник»

6.7. Неузгодження в часі частин складного присудка

6.8. Синтаксична неоднозначність

6.9. Інші

\section{VII СЕМАНТИЧНІ ПОМИЛКИ}

7.1. Вживання слів без урахування значення та контексту (помилки слововживання)

7.2. Поєднання конкретного та абстрактного

7.3. Підміна конкретного невизначеним

7.4. Порушення семантичної сполучуваності

7.5. Семантично непов'язані частини речення

7.6. Тавтологія

7.7. Плеоназм

7.8. Хибна / часткова синонімія

7.9. Негативна семантика

7.10. Порушення семантичної однорідності

7.11. Інші

\section{VIII. СТИЛІСТИЧНІ ПОМИЛКИ}

8.1. Невдала образність

8.2. Помилка фразеології

8.3. Контактне положення однакових слів

8.4. Стяжіння

8.5. Помилка в розгортанні теми

8.5.1. Еліпсис

8.5.2. Раптова зміна теми

8.5.3. Включення елементів іншого стилю

\section{IХ ФАКТИЧНІ ПОМИЛКИ}

9.1. Помилка в записі власного імені (назви)

9.2. Помилка при посиланні на нормативно-правові акти

9.3. Помилка в цифрах

9.4. Помилка в даті

9.5. Зазначене видається за дійсне

9.6. Зсув смислового плану

9.7. Застарілі відомості

\section{Х ЛОГІЧНІ ПОМИЛКИ}

10.1. Порушення логіки викладу

10.1.1. Відсутній смисловий зв'язок між частинами речення

10.1.2. Відсутній зв'язок між відповідями та питаннями 
10.1.3. Відсутній зв'язок між реченнями одного блоку думки

10.2. Хибний висновок

10.3. Недостатня підстава для висновку

10.4. Суперечність

10.5. Неузгодженість

10.6. Подвійне заперечення

10.7. Порушення закону тотожності

10.8. Підміна поняття

10.9. Логічний стрибок

10.10. Абсурдність

\section{ХІ ВНУТРІШНЯ НЕУЗГОДЖЕНІСТЬ}

\subsection{2. Корпусні технології в авторознавчих експертизах}

У застосуванні корпусних технологій в авторознавчих експертизах заслуговує уваги досвід колег з Інституту російської мови імені В. В. Виноградова PAН (А. М. Баранов, О. М. Грунченко, Ю. К. Пирогова, Е. І. Почтар та ін.), що розробили метод атрибуції за умов «множинної невизначеності», коли від експертів вимагається встановити кількість авторів, що працювали над текстом та визначити авторський внесок кожного з них.

Такого роду дослідження російських колег базуються на лінгвостатистичному аналізі неповнозначної лексики (часток, сполучників, прийменників, модальних слів, ввідних та вставних конструкцій тощо) та експериментально встановленій відносній сталості їі частотних параметрів у текстах обсягом від 1000 до 2000 слововживань (що становить приблизно від 4 до 9 стандартних сторінок, надрукованих кеглем 14 пунктів із міжрядковим інтервалом 1,5).

Розроблений метод передбачає утворення двох лінгвістичних корпусів: 1) корпусу аналізованих текстів; 2) корпусу еталонних, що презентують індивідуальний стиль імовірних авторів.

Подальші дослідницькі дії спрямовуються на 1) укладання словників корпусу аналізованого тексту та корпусу еталонних із зазначенням абсолютної та відносної частоти вживань у відповідному корпусі; 2) окреслення предмета дослідження шляхом видалення повнозначних лексем з укладених словників; 3) зіставлення словників неповнозначної лексики для виявлення одиниць із близьким значенням частоти (поріг близькості встановлюється окремо для кожного випадку за спеціальною методикою); 4) формування кластерів «авторських» лексем, до яких входять пари неповнозначних лексем із порівнюваних корпусів із близькою за значенням частотністю.

Науковцями Інституту російської мови експериментальним шляхом встановлено, що одноосібні тексти публіцистичного стилю містять від 60 до 90 
спільних неповнозначних лексем, тоді як скомпільовані з текстів різних авторів від 20 до $35 .^{186}$

В Українському мовно-інформаційному фонді НАН України також розроблено методику проведення лінгвістичних експертиз за умов «множинної невизначеності», але, на відміну від російських колег, науковці Фонду спиралися на статистичні показники повнозначної лексики. В основу методики покладено міркування щодо унікальності суб'єктивного лексикону та правил оперування ним. Хоча суб’єктивний лексикон перебуває в стані постійного розширення, в ньому обов'язково є зона індивідуальних лексичних домінант. Опис будь-якого предмета думки автор здійснює, використовуючи, насамперед, лексику цієї зони. Звідси важливе для атрибуційного дослідження припущення: змістово непов'язані тексти 3 високим відсотком спільних слів більш імовірно належать одному автору, ніж декільком.

Методику розроблено та використано в ході атрибуційного дослідження рукопису, проведеного на запит Департаменту спеціальних розслідувань Генеральної прокуратури України (про це див. у п. 22.3.7), тому обмежимось їі викладенням у загальних рисах.

Для дослідження був наданий рукопис, що структурно складається 316 глав. Необхідно було підтвердити чи спростувати заявлене в рукопису одноосібне авторство.

У тексті встановлено два блоки глав (блок 1-3 глави; блок 2-4 глави) 3 експліцитним (явним) змістовим зв'язком - глави в межах кожного блоку утворюють хронологічно послідовну розповідь, тобто є змістово пов'язаними. Також встановлено, що передмова та висновок утворюють кільцеву композицію. Змістові зв’язки решти глав між собою та з главами, віднесеними до блоків 1 та 2, оцінено як відсутні або недостатньо виражені.

Для підрахунку частки спільних повнозначних слів із тексту глав рукопису було вилучено фрагменти, визначені як запозичені, цитати, власні назви (географічні та геополітичні назви, імена людей, назви офіційних та нормативних документів, закладів, установ, об’єднань, партій тощо), складені слова, назви подій, числа, проміжки часу, абревіатури та інші скорочення.

Після чого до тексту кожної глави в автоматизованому режимі було побудовано два словники. Реєстрову частину першого склали словоформи, впорядковані за кількістю входжень, другого - впорядковані за абеткою леми. Далі словники лем було завантажено до корпусу для визначення частки спільних одиниць лексики. Результатом обчислення стала матриця розміром 16х16, де

${ }^{186}$ Баранов А. Н. Лингвистическая экспертиза текста: теория и практика: учеб. пос. / А. Н. Баранов. 2-е изд. Москва: Флинта: Наука. 2009. 
числа на перетині стовпчиків та рядків позначають відсоток спільних лем від сумарної кількості лем відповідних глав рукопису.

Аналіз результатів обчислень та змістової близькості глав не підтвердив одноосібного авторства - в рукопису встановлено главу 3 явним змістовим зв'язком 3 іншими главами в межах одного з блоків, але низьким лексичним (спільним $\epsilon$, щонайменше, кожне восьме слово, тобто лексична близькість перебуває на рівні семантичного ядра мови), тоді як між іншими главами кожного блоку лексичний зв'язок є високим - кожне п'яте або четверте повнозначне слово. Незалежна інформація, отримана в ході слідчих дій, підтвердила висновки експертів.

Ще одним науковим та технологічним результатом Українського мовноінформаційного фонду НАН України є методика ідентифікації запозичень корпусними засобами, заснована на понятті слабкої синонімії текстів.

У філології поняття «синонімії» застосовується, зазвичай, до слів або словосполучень (згадаймо класичне визначення: «синоніми - слова однієї частини мови, різні за звучанням і написанням, що мають дуже близьке або тотожне лексичне значення»). Але тексти теж можуть мати властивості близькості за змістом, тобто в певному сенсі бути синонімічними. Подамо формальне визначення синонімії текстів (для спрощення викладу вважаємо тексти одномовними).

Нехай тексти Т1 і Т2 є близькими за змістом, але відрізняються за формою. Ці тексти вважатимемо такими, що перебувають у відношенні слабкої синонімії. Зазначений випадок має місце, якщо хтось компілює запозичені тексти без змін, лише доповнюючи їх власним текстом для зв’язності викладу.

Сформулюємо критерії слабкої синонімії текстів. Для цього поставимо у відповідність та порівняємо набори множини слів як деяких випадкових величин, що характеризують ці тексти. Це завдання досить нескладно розв'язується формальними методами. Пропонується такий критерій слабкої синонімії («критерій №1»): якщо більше n \% слів тексту Т1 наявні в тексті Т2 в тих самих формах, якщо більше m \% біграм (будь-яких двох слів, що стоять поруч) в тексті T1, наявні в тексті Т2 в тих самих формах, i k \% триграм (трійок слів) текстів Т1 i Т2 збігаються, то тексти є слабко синонімічними. Чисельні значення m, n, k $\epsilon$ функціями від довжини тексту й кількості одиниць у словниках лексики аналізованих текстів. Визначення функцій для m, n, k перебуває в процесі дослідження.

Введемо поняття лексичної відстані двох текстів. Назвемо лексичною відстанню тексту Т1 від тексту Т2 таку величину || $\mathrm{T} 1, \mathrm{~T} 2 \|=|\mathrm{T} 1 \cap \mathrm{T} 2| /|\mathrm{T} 1|$, де $|\mathrm{T}|-$

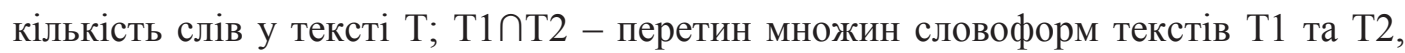
що збігаються за написанням. Із визначення випливають такі властивості лексичної відстані $\|\mathrm{T} 1, \mathrm{~T} 2\| \neq\|\mathrm{T} 2, \mathrm{~T} 1\|,\|\mathrm{T} 1, \mathrm{~T} 2\| \leq 1$, якщо Т1 та Т2 не збігаються та 
$\|\mathrm{T} 1, \mathrm{~T} 2\|=1$, якщо $\mathrm{T} 1=\mathrm{T} 2$. Позначимо через $\mathrm{T}_{1}{ }^{2}$ множину біграм словоформ тексту $\mathrm{T} 1$, а через $\mathrm{T}_{1}{ }^{3}-$ множину триграм словоформ, відповідно через $\mathrm{T}_{1}{ }^{\mathrm{n}}-$ множину кортежів 3 n словоформ. Тоді лексичну відстань n-го порядку визначимо в такий спосіб: $\quad\|\mathrm{T} 1, \mathrm{~T} 2\|_{\mathrm{n}}=\left|\mathrm{T}_{1}{ }^{\mathrm{n}} \cap \mathrm{T}_{2}{ }^{\mathrm{n}}\right| /(|\mathrm{T} 1|-(\mathrm{n}-1))$. Тепер Критерій №1 можна переформулювати так: якщо $\|\mathrm{T} 1, \mathrm{~T} 2\|<\mathrm{k},\|\mathrm{T} 1, \mathrm{~T} 2\|_{2}<\mathrm{m},\|\mathrm{T} 1, \mathrm{~T} 2\|_{3}<\mathrm{n}$, де k, m, n<1, то тексти Т1 та Т2 є слабкосинонімічними.

Критерій №1 «працює» лише у випадку, коли аналізовані тексти мають спільні фрагменти, тобто є близькими і за змістом, і за формою. Розглянемо інший випадок, коли тексти є близькими за змістом, але різними за формою. Це має місце, якщо запозичений текст піддається різного роду модифікаціям.

Для визначення слабкої синонімії в такому випадку потрібні більш складні критерії. Введемо лексико-граматичну відстань першого порядку між текстами Т1 та Т2 у такий спосіб:

$$
\|\mathrm{T} 1, \mathrm{~T} 2\|^{\mathrm{LG}}=\frac{\sum_{i=1,|T 1| j=1,|T 2|} v_{i} v_{j} \lambda}{|T 1|}, \text { де } \lambda=\left\{\begin{array}{c}
1, v_{i}=v_{j} \\
\frac{1}{2}, v_{i} \text { синонім } v_{j} \\
\frac{1}{4}, \operatorname{gr}\left(v_{i}\right)=\operatorname{gr}\left(v_{j}\right)
\end{array}\right.
$$

Лексико-граматична відстань n-го порядку між текстами Т1 та T2

$$
\|\mathrm{T} 1, \mathrm{~T} 2\|_{\mathrm{n}}^{\mathrm{LG}}=\frac{\sum_{i=1, T 1|; j=1, T 2|} v_{i}^{n} v_{j}^{n} \lambda^{n}}{|T 1|-(n-1)}
$$

Встановлюємо Критерій 2 слабкої синонімії: якщо більше $\mathrm{n}$ \% слів тексту T1 присутні в тексті Т2 в тих самих формах, якщо більше m \% біграм тексту Т1 присутні в тексті Т2 в тих самих формах і k\% триграм текстів Т1 і Т2 збігаються, такі тексти є слабкосинонімічними.

Практичне застосування. Для функціонування розробленої на основі розглянутого методу програми формується комп'ютерна база еталонних текстів, які, на думку експертів, $\epsilon$ ймовірними джерелами запозичених фрагментів. Алгоритм ідентифікації передбачає такі етапи: 1) формування лексичних систем аналізованого та еталонних текстів у вигляді множин слів у тих граматичних значеннях, в яких вони зустрічаються в аналізованих текстах; 2) формування підмножин декартових добутків рангу 1, 2 та 3 для кожного тексту (називаємо ці підмножини множинами рангу 1, 2 та 3, відповідно); 3) побудова послідовних перетинів множини рангу 1 аналізованого тексту з аналогічними множинами для кожного тексту 3 бази еталонних; 4) обчислення для кожного тексту бази близькості рангу 1 як відношення потужності перетину множин рангу 1 для аналізованого тексту та тексту 3 бази, до потужності множини рангу 1 аналізованого тексту; 5) порівняння близькості рангу 1 з емпірично визначеним пороговим значенням (для рангу 1 цей показник $\geq 0,5$ ); 6) побудова перетину множин рангу 2 визначених на попередньому етапі текстів із відповідними 
множинами рангу 2 еталонних текстів із бази; 7) побудова та обчислення відношення потужностей одержаних перетинів до потужностей відповідних множин рангу 2 (результати обчислень кваліфікуються як близькість рангу 2); 8) визначення текстів, у яких обчислена близькість рангу 3 перевищує емпірично визначене порогове значення (для рангу 3 воно дорівнює 0.3); 9) визначення текстів, у яких обчислена близькість рангу 3 перевищує емпірично визначене порогове значення (для рангу 3 воно дорівнює 0.1 ).

Якщо в базі є текст, близькість якого з аналізованим за рангом $3>0,1$, аналізований текст ідентифікується як запозичений.

Описаний метод втілено в Систему аналізу текстів, яку спільними зусиллями лінгвістів та фахівців з інформаційних технологій Українського мовноінформаційного фонду нині доведено до рівня промислового зразка. Цю систему було застосовано, зокрема, при проведенні експертизи докторської дисертації К. М. Кириленко (див. п. 22.3.6). Нижче наведено реальні екранні форми Системи аналізу текстів: 1) формування матриці аналізу шляхом завантаження до Системи тексту аналізованої дисертації та текстів інших авторів, з якими, на обгрунтовану думку експерта, потрібно було виконати порівняння (рис. 22.1); 2) результат порівняння тексту дисертації К. М. Кириленко (ліве поле екранної форми) 3 текстом автореферату дисертації на здобуття наукового ступеня кандидата філософських наук О. І. Сандиги (праве поле). Кольором та накресленням шрифту позначено ланцюги лексем, що збігаються (рис. 22.2).

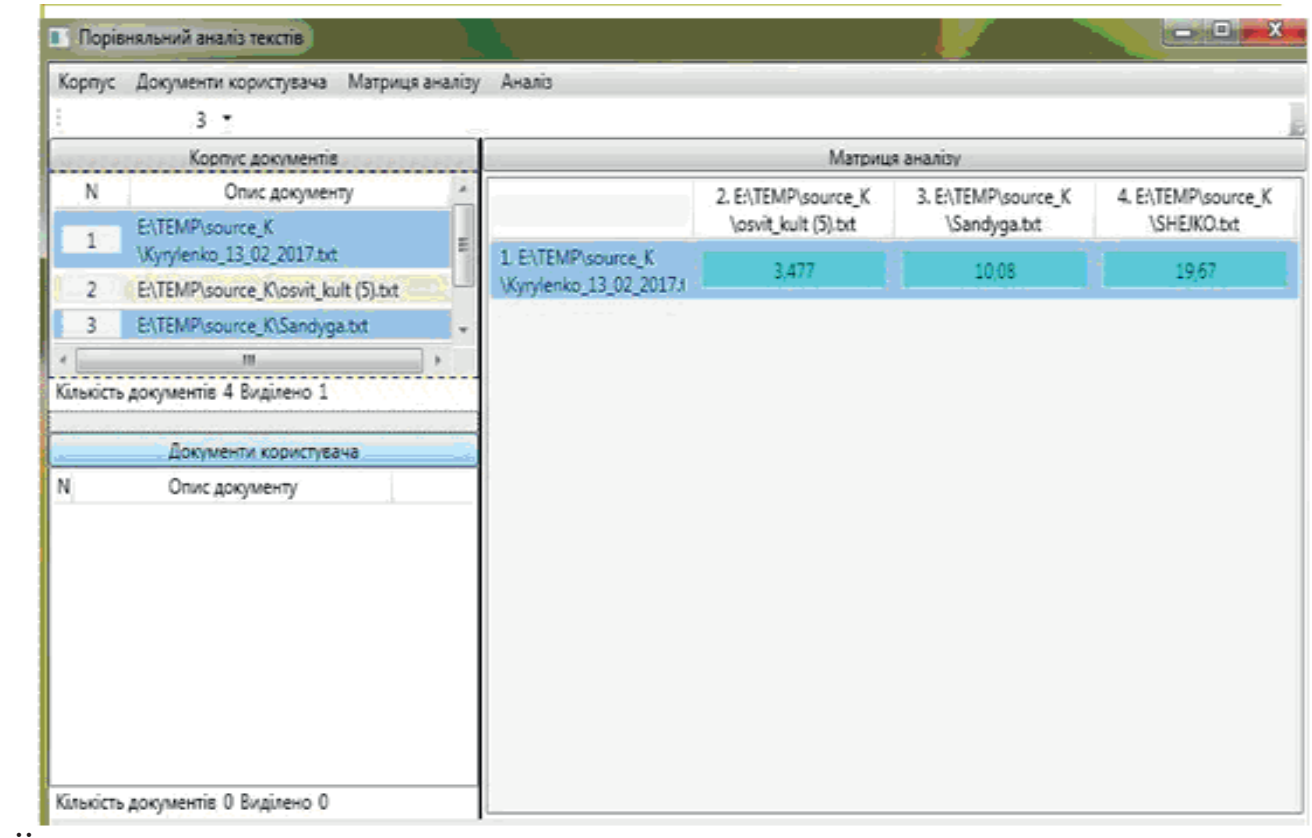

Рис. 22.1. Формування експертом матриці аналізу 


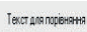

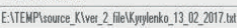

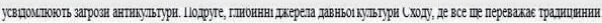

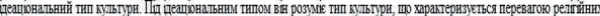

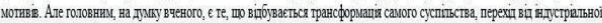

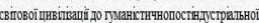

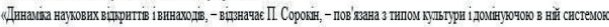

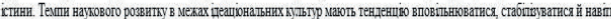

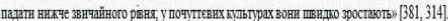

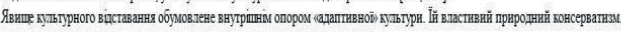

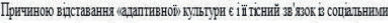

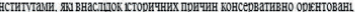

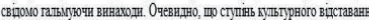

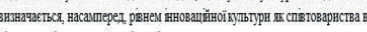

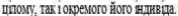

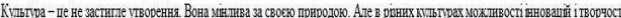

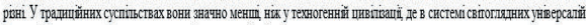
қатегорї новвзии та прогресу маюють прірритетву пінність

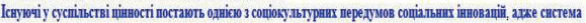

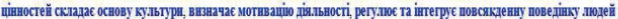

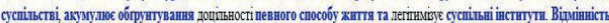

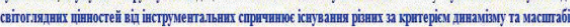

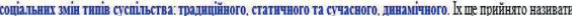

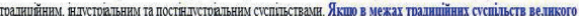

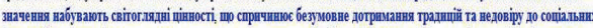

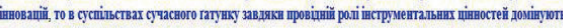
індовапійі тропеси [355].

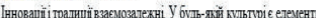

тратецйності та нновацйності Традиці- стйк та знатущі компонент

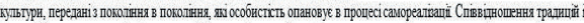

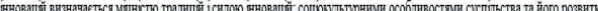

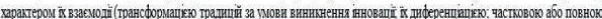

leacr-eranon

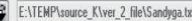

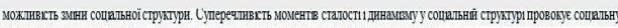

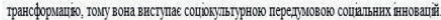

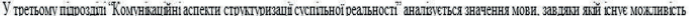

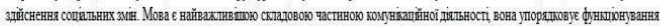

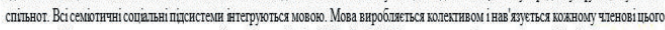

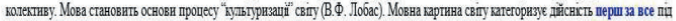

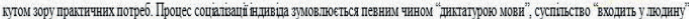

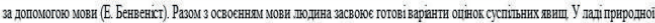

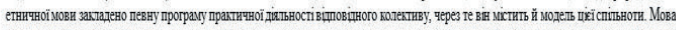

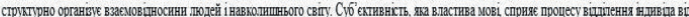

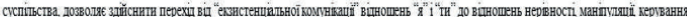

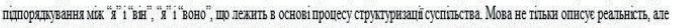

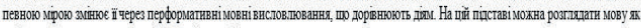

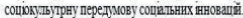

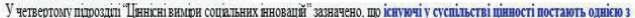

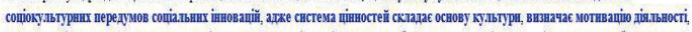

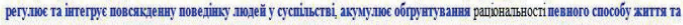

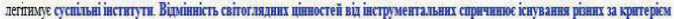

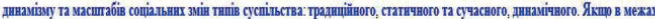

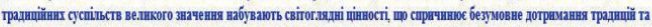

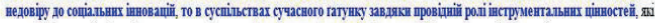

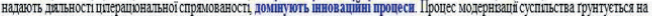

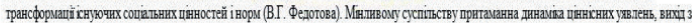

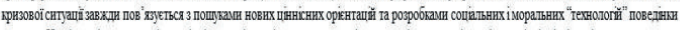

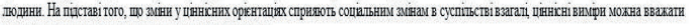

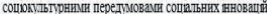

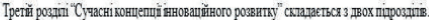

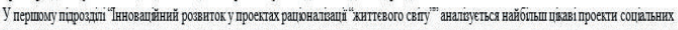

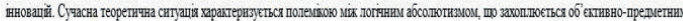

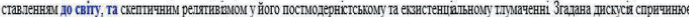

Рис. 22.2. Результат пошуку фрагментів, що збігаються в еталонному та аналізованому текстах

\subsection{3. Корпусні технології в експертизах на предмет прихованих мотивів}

У застосуванні лінгвістичної та юридично-лінгвістичної експертизи особливе місце посідає експертиза політичних і правових документів, у тому числі законопроектів і законодавчого процесу взагалі. Цей різновид експертизи, очевидно, має здійснюватися за іншими методиками, ніж експертиза текстів, пов’язана з розв'язанням конфліктних ситуацій, хоч обидва різновиди і мають спільний предмет, адже природна мова виконує роль субстрату мови юридичної як окремого соціолекту.

Зрозуміло, що політичні та правові документи як об'єкт лінгвістичної та юридично-лінгвістичної експертизи відзначаються певною специфікою, 3 якої випливають завдання та методи експертного дослідження.

На відміну від приватних висловлювань та мас-медійних текстів політичні та правові документи, зазвичай, є добре редакційно опрацьованими та ретельно верифікованими перед оприлюдненням. Унаслідок цього малоймовірною видається наявність у таких текстах непродуманих, занадто емоційних (якщо останнього не вимагає мета та спрямованість документа) висловлювань і прикрих лінгвістичних помилок. Отже, методи лінгвістичної експертизи, які слід застосовувати до текстів такого роду, повинні містити інструменти дослідження, за допомогою яких можна було б експлікувати підсвідомі настанови авторів цих 
документів, виявляти в них логічні закономірності та конфлікти. На сучасному етапі розвитку психо- та нейролінгвістики не виключається застосування прийомів побудови текстів 3 урахуванням відомих ефектів нейролінгвістичного програмування, тому необхідно розвивати й використовувати методи ідентифікації прийомів зазначеного типу.

Ці загальні міркування проілюструємо результатами проведеної в Українському мовно-інформаційному фонді НАН України лінгвістичної експертизи передвиборчих програм політичних об'єднань (партій та блоків), представлених в українському парламенті станом на липень 2004 p. ${ }^{187}$

Виконання зазначеної експертизи зводилось до введення до УНЛК текстів передвиборчих програм для опрацювання корпусними інструментами та в інтерпретації даних, одержаних у результаті такого опрацювання.

Об'єктом експертизи виступили передвиборчі програми таких політичних об'єднань:

\begin{tabular}{|c|c|}
\hline № & Назва \\
\hline 1 & Українська республіканська партія «Собор» (УРПС) \\
\hline 2 & Соціал-демократична партія України (об’єднана) (СДПУ(о)) \\
\hline 3 & Народний рух України (НРУ) \\
\hline 4 & Народно-демократична партія (НДП) \\
\hline 5 & Аграрна партія України (Народна аграрна партія) (НАПУ) \\
\hline 6 & «Трудова Україна» (ТУ) \\
\hline 7 & Соціалістична партія України (СПУ) \\
\hline 8 & Партія промисловців і підприємців України (ПППУ) \\
\hline 9 & Партія регіонів (ПР) \\
\hline 10 & Комуністична партія України (КПУ) \\
\hline 11 & Виборчий блок Віктора Ющенка «Наша Україна» (НУ) \\
\hline 12 & Виборчий блок Юлії Тимошенко (БЮТ) \\
\hline
\end{tabular}

Аналіз проводився за комбінованою методикою, що включає формальностатистичні, семантико-статистичні та власне семантичні методи.

Формально-статистичними методами було проведено дослідження статистики лексичної системи аналізованих текстів. Семантико-статистичними програмне визначення ступеня спорідненості аналізованих текстів на основі розглянутих вище критеріїв слабкої синонімії - формального інструменту визначення змістової близькості текстів. У дослідженні застосовано критерії трьох рангів: рангу 1 («слабкий критерій» - за статистикою лексичної системи), рангу 2 («середній критерій» - за статистикою біграм - лексичних конструкцій довжини 2 та рангу 3 («сильний критерій» - за статистикою триграм - лексичних конструкцій довжини 3) (див. п. 22.4.2).

Із метою проведення семантичного аналізу текстів передвиборчих програм політичних об’єднань попередньо було проаналізовано текст Конституції України

${ }^{187}$ Архівний матеріал в якості ілюстративного було обрано з етичних міркувань згідно 3 концепцією «наука поза політикою». 
на предмет визначення лінгвістичних термів найважливіших сфер суспільного життя України, проблеми яких мали би знайти відображення в передвиборчих програмах політичних об'єднань. Встановлені сфери послугували назвами лексико-семантичних полів: «правове поле», «духовний розвиток суспільства», «соціальний захист», «економіка», «охорона довкілля» тощо. У кожному 3 визначених семантичних полів було встановлено лексико-семантичні групи (ЛСГ), що фігурують у передвиборчих програмах. Семантичне дослідження полягало в тестуванні текстів передвиборчих програм за допомогою модельних лексико-семантичних полів, що, на думку науковців Фонду, детермінують семантичний простір суспільно-політичної практики України.

У межах формально-статистичних досліджень за допомогою розробленої комп'ютерної програми було побудовано частотні конкорданси текстів передвиборчих програм зазначених політичних об’єднань (табл. 22.1) та частотний конкорданс Конституції України. При побудові конкордансів не враховувались «стоп-слова», внесок яких у семантику незначний.

Таблиця 22.1. Статистика конкордансів текстів передвиборчих програм політичних об'єднань - суб'єктів виборчого процесу 2004 р.

\begin{tabular}{|l|l|c|c|}
\hline № & Назва партії / блоку & $\begin{array}{l}\text { Кількість } \\
\text { слововживань }\end{array}$ & Кількість реєстрових одиниць \\
\hline 1 & СДПУ(о) & 17953 & 2946 \\
\hline 2 & НРУ & 11038 & 2300 \\
\hline 3 & СПУ & 9598 & 2153 \\
\hline 4 & ПППУ & 8880 & 1931 \\
\hline 5 & ТУ & 7670 & 1823 \\
\hline 6 & ПР & 6645 & 1580 \\
\hline 7 & НДП & 5998 & 1519 \\
\hline 8 & НУ & 3896 & 1082 \\
\hline 9 & УРПС & 3525 & 1117 \\
\hline 10 & НАПУ & 3150 & 1040 \\
\hline 11 & БЮТ & 1071 & 577 \\
\hline 12 & КПУ & 866 & 465 \\
\hline \multicolumn{2}{|r|}{ Загалом: } & 80290 & 5933 \\
\hline
\end{tabular}

У табл. 22.2 у порядку зменшення наведено 20 найбільш частотних лексем у проаналізованих передвиборчих програмах політичних об'єднань.

Таблиця 22.2. Найчастотніші лексеми у передвиборчих програмах політичних об'єднань - суб'єктів виборчого процесу 2004 р.

\begin{tabular}{|l|c|c|c|c|c|c|}
\hline$№$ & УРПС & СДПУ & НРУ & НДП & НАПУ & ТУ \\
\hline 1 & партія & держава & Україна & розвиток & партія & Україна \\
\hline 2 & Україна & соціальний & Рух & партія & Україна & трудовий \\
\hline 3 & український & державний & український & Україна & аграрний & соціальний \\
\hline
\end{tabular}




\begin{tabular}{|c|c|c|c|c|c|c|}
\hline 4 & національний & економічний & Держава & держава & політичний & держава \\
\hline 5 & держава & суспільство & Державний & державний & політик & партія \\
\hline 6 & розвиток & розвиток & національний & економічний & держава & суспільство \\
\hline 7 & система & повинний & Політичний & створення & соціальний & розвиток \\
\hline 8 & політик & система & Система & соціальний & розвиток & державний \\
\hline 9 & державний & Україна & Розвиток & суспільство & сільський & громадянин \\
\hline 10 & обстоювати & вважати & Громадянин & політик & громадянин & влада \\
\hline 11 & створення & громадянин & Hapo & діяльність & діяльність & політичний \\
\hline 12 & соціальний & право & Соціальний & забезпечення & державний & економіка \\
\hline 13 & суспільство & економіка & економічний & основа & захист & країна \\
\hline 14 & забезпечення & національний & Право & економіка & економічний & політик \\
\hline 15 & влада & & Безпека & національний & український & система \\
\hline 16 & громадянин & створення & $\mathrm{OcH}$ & орган & $\begin{array}{c}\text { сільськогоспо } \\
\text { дарський }\end{array}$ & праця \\
\hline 17 & освіта & політик & забезпечення & система & вважати & людина \\
\hline 18 & сфера & діяльність & Вважати & громадянин & екологічний & організація \\
\hline 19 & собор & людина & Влада & формування & & робот \\
\hline 20 & підтримка & забезпечення & Створення & право & сфера & основа \\
\hline
\end{tabular}

\begin{tabular}{|l|c|c|c|c|c|c|}
\hline № & СПУ & ПППУ & ПР & КПУ & НУ & БЮТ \\
\hline 1 & Україна & партія & партія & державний & Україна & конфлікт \\
\hline 2 & соціальний & Україна & Україна & країна & влада & Україна \\
\hline 3 & розвиток & соціальний & розвиток & Україна & розвиток & державний \\
\hline 4 & суспільство & державний & створення & соціальний & суспільство & капітал \\
\hline 5 & партія & розвиток & держава & партія & громадянин & прибуток \\
\hline 6 & держава & політик & система & комуніст & світовий & життя \\
\hline 7 & влада & держава & державний & право & державний & влада \\
\hline 8 & людина & система & регіон & розвиток & держава & суспільство \\
\hline 9 & праця & економічний & регіональний & суспільство & людина & громадянин \\
\hline 10 & країна & суспільство & суспільство & проти & система & забезпечити \\
\hline 11 & політичний & створення & людина & народ & можливість & запровадити \\
\hline 12 & підприємство & національний & політик & держава & забезпечити & земля \\
\hline 13 & інтерес & український & соціальний & влада & інтерес & головний \\
\hline 14 & політик & політичний & новий & основа & політик & податок \\
\hline 15 & життя & забезпечення & громадянин & духовний & добробут & право \\
\hline 16 & система & економіка & завдання & політичний & український & новий \\
\hline 17 & виробництво & країна & економічний & сфера & економіка & власність \\
\hline 18 & форма & реалізація & право & відновити & процес & зробити \\
\hline 19 & економіка & народ & політичний & система & країна & розвиток \\
\hline 20 & СПУ & сфера & влада & монополія & демократичний & можливість \\
\hline
\end{tabular}

Результати семантико-статистичного аналізу наведено в табл. 22.3-22.6.

Таблиця 22.3. Спорідненість рангу 1 текстів передвиборчих програм політичних об’єднань (у \%)

\begin{tabular}{l|l|c|c|c|c|c|c|c|c|c|c|c|c|c|}
\hline $\begin{array}{l}\text { Назва } \\
\text { партії }\end{array}$ & УРПС & СДПУ & НРУ & НДП & НАПУ & ТУ & СПУ & ПППУ & ПР & КПУ & НУ & БЮТ & $\begin{array}{l}\text { Консти- } \\
\text { туція } \\
\mathbf{У}_{\text {країни }}\end{array}$ \\
\hline УРПС & 100 & 58 & 51 & 41 & 30 & 41 & 44 & 44 & 41 & 11 & 28 & 13 & 33 \\
\hline СДПУ(о) & 19 & 100 & 35 & 27 & 18 & 29 & 32 & 33 & 27 & 6 & 18 & 7 & 20 \\
\hline
\end{tabular}




\begin{tabular}{|l|c|c|c|c|c|c|c|c|c|c|c|c|c|}
\hline НРУ & 20 & 42 & 100 & 27 & 18 & 28 & 31 & 32 & 26 & 7 & 18 & 7 & 21 \\
\hline НДП & 30 & 61 & 51 & 100 & 30 & 41 & 45 & 46 & 42 & 10 & 27 & 11 & 29 \\
\hline НАПУ & 35 & 64 & 55 & 48 & 100 & 46 & 53 & 52 & 45 & 15 & 30 & 13 & 34 \\
\hline ТУ & 24 & 52 & 41 & 32 & 23 & 100 & 38 & 38 & 33 & 8 & 24 & 9 & 25 \\
\hline СПУ & 20 & 45 & 16 & 28 & 20 & 30 & 100 & 44 & 28 & 8 & 19 & 8 & 22 \\
\hline ПППУ & 24 & 53 & 43 & 33 & 23 & 35 & 39 & 100 & 35 & 8 & 23 & 10 & 24 \\
\hline ПР & 28 & 56 & 44 & 39 & 26 & 39 & 42 & 45 & 100 & 9 & 27 & 10 & 27 \\
\hline КПУ & 35 & 63 & 54 & 44 & 40 & 46 & 59 & 49 & 44 & 100 & 31 & 19 & 38 \\
\hline НУ & 30 & 58 & 48 & 39 & 27 & 44 & 44 & 46 & 41 & 10 & 100 & 14 & 34 \\
\hline БЮТ & 34 & 57 & 47 & 37 & 28 & 41 & 44 & 46 & 38 & 16 & 34 & 100 & 37 \\
\hline $\begin{array}{l}\text { Консти- } \\
\text { туція } \\
\text { України }\end{array}$ & 19 & 36 & 31 & 23 & 17 & 25 & 29 & 27 & 23 & 7 & 16 & 8 & 100 \\
\hline
\end{tabular}

Таблиця 22.4. Спорідненість рангу 2 текстів передвиборчих програм політичних об'єднань (у \%)

\begin{tabular}{|l|c|c|c|c|c|c|c|c|c|c|c|c|c|}
\hline $\begin{array}{l}\text { Назва } \\
\text { Партії }\end{array}$ & УРПС & СДПУ & НРУ & НДП & НАПУ & ТУ & СПУ & ПППУ & ПР & КПУ & НУ & БЮТ & $\begin{array}{l}\text { Консти- } \\
\text { туція } \\
\text { Ураӥни }\end{array}$ \\
\hline УРПС & 100 & 14 & 12 & 10 & 5 & 8 & 7 & 10 & 9 & 0 & 4 & 1 & 6 \\
\hline СДПУ(о) & 3 & 100 & 6 & 5 & 3 & 5 & 6 & 6 & 5 & 0 & 3 & 0 & 3 \\
\hline НРУ & 3 & 10 & 100 & 6 & 3 & 5 & 5 & 6 & 5 & 0 & 3 & 0 & 4 \\
\hline НДП & 6 & 15 & 11 & 100 & 6 & 8 & 7 & 10 & 9 & 0 & 4 & 1 & 5 \\
\hline НАПУ & 6 & 17 & 13 & 12 & 100 & 10 & 11 & 11 & 9 & 2 & 4 & 1 & 7 \\
\hline ТУ & 4 & 12 & 8 & 6 & 4 & 100 & 6 & 7 & 6 & 0 & 4 & 1 & 4 \\
\hline СПУ & 2 & 11 & 6 & 4 & 3 & 5 & 100 & 6 & 5 & 1 & 2 & 0 & 4 \\
\hline ПППУ & 4 & 13 & 8 & 7 & 4 & 6 & 7 & 100 & 7 & 1 & 3 & 1 & 4 \\
\hline ПР & 5 & 13 & 9 & 8 & 4 & 7 & 7 & 10 & 100 & 1 & 4 & 1 & 5 \\
\hline КПУ & 3 & 14 & 7 & 6 & 7 & 5 & 12 & 9 & 7 & 100 & 3 & 1 & 6 \\
\hline НУ & 4 & 13 & 9 & 7 & 3 & 8 & 7 & 8 & 7 & 0 & 100 & 1 & 5 \\
\hline БЮТ & 6 & 12 & 8 & 6 & 4 & 7 & 7 & 7 & 6 & 0 & 5 & 100 & 5 \\
\hline $\begin{array}{l}\text { Консти } \\
\text { туція } \\
\text { України }\end{array}$ & 2 & 7 & 5 & 3 & 2 & 3 & 4 & 2 & 3 & 0 & 2 & 0 & 100 \\
\hline
\end{tabular}

Таблиця 22.5. Спорідненість рангу 3 текстів передвиборчих програм політичних об’єднань (у \%)

\begin{tabular}{|c|c|c|c|c|c|c|c|c|c|c|c|c|c|}
\hline $\begin{array}{l}\text { Назва } \\
\text { партії }\end{array}$ & УРПC & СДПУ & HPY & НДП & НАПУ & Ty & СПУ & ПППУ & ПР & КПУ & HУ & \begin{tabular}{|l|} 
БЮТ \\
\end{tabular} & \begin{tabular}{|l|} 
Консти- \\
туція \\
України \\
\end{tabular} \\
\hline УРПС & 100 & 1 & 2 & 1 & 0 & 1 & 0 & 1 & 1 & 0 & 0 & 0 & 1 \\
\hline СДПУ(о) & 0 & 100 & 0 & 0 & 0 & 0 & 0 & 1 & 0 & 0 & 0 & 0 & 0 \\
\hline HPУ & 0 & 1 & 100 & 1 & 0 & 0 & 0 & 0 & 0 & 0 & 0 & 0 & 0 \\
\hline нДП & 1 & 2 & 2 & 100 & 1 & 1 & 0 & 1 & 1 & 0 & 0 & 0 & 0 \\
\hline НАПУ & 0 & 2 & 2 & 3 & 100 & 1 & 2 & 1 & 1 & 0 & 0 & 0 & 1 \\
\hline TУ & 0 & 1 & 1 & 0 & 0 & 100 & 0 & 1 & 0 & 0 & 0 & 0 & 0 \\
\hline СПУ & 0 & 1 & 0 & 0 & 0 & 0 & 100 & 0 & 0 & 0 & 0 & 0 & 0 \\
\hline
\end{tabular}




\begin{tabular}{|l|c|c|c|c|c|c|c|c|c|c|c|c|c|}
\hline ПППУ & 0 & 2 & 1 & 1 & 0 & 0 & 0 & 100 & 1 & 0 & 0 & 0 & 0 \\
\hline ПР & 0 & 2 & 1 & 1 & 0 & 0 & 0 & 1 & 100 & 0 & 0 & 0 & 0 \\
\hline КПУ & 0 & 1 & 0 & 0 & 1 & 0 & 2 & 1 & 0 & 100 & 0 & 0 & 0 \\
\hline НУ & 0 & 2 & 1 & 0 & 0 & 1 & 0 & 1 & 0 & 0 & 100 & 0 & 0 \\
\hline БЮТ & 0 & 1 & 0 & 0 & 0 & 1 & 0 & 0 & 0 & 0 & 0 & 100 & 0 \\
\hline $\begin{array}{l}\text { Констит } \\
\text { уція } \\
\text { України }\end{array}$ & 0 & 0 & 1 & 0 & 0 & 0 & 0 & 0 & 0 & 0 & 0 & 0 & 100 \\
\hline
\end{tabular}

Таблиця 22.6. Інтегральна кореляція змістів текстів передвиборчих програм

\begin{tabular}{|c|c|c|c|}
\hline Назва партії / блоку & Ранг 1 & Ранг 2 & Ранг 3 \\
\hline УРПС & 435 & 86 & 8 \\
\hline СДПУ(о) & 271 & 45 & 1 \\
\hline НРУ & 277 & 50 & 2 \\
\hline НДП & 423 & 82 & 9 \\
\hline НАПУ & 490 & 103 & 13 \\
\hline ТУ & 347 & 62 & 3 \\
\hline СПУ & 288 & 49 & 1 \\
\hline ПППУ & 350 & 65 & 5 \\
\hline ПР & 392 & 74 & 5 \\
\hline КПУ & 522 & 80 & 5 \\
\hline НУ & 435 & 72 & 5 \\
\hline БЮТ & 459 & 73 & 2 \\
\hline
\end{tabular}

На лексичному рівні лексико-семантичні групи представлені в текстах відповідними ключовими словами. Наприклад, для ЛСГ «духовний розвиток людини» ключовими є слова особистість, мораль, моральний, духовність, духовний тощо.

Семантичний аналіз здійснювався у межах тематичних груп за такими лексико-семантичними групами:

1. Правова держава: громадянство; національне законодавство; оборона; місцеве самоврядування; зовнішня політика; права, свободи, обов'язки громадян; Україна; політичні партії; суспільні відносини; держава й суспільство.

2. Охорона довкілля.

3. Духовний розвиток суспільства: наука, культура; освіта; інформація; духовний світ людини.

4. Соціальний захист: медична допомога; гуманітарні проблеми; пенсійне забезпечення; діти; інваліди; молодь; сім'я; праця; добробут; демографія.

5. Економіка: власність; виробництво; податок; реформа; ринок; сільське господарство; фінанси; технології; корупція.

Аналіз проводився в такій послідовності. На текстах, автоматично розмічених за кодами граматичних класів за допомогою системи автоматичного морфологічного аналізу, встановлювалася лексична структура кожного 3 них. 
Об'єктом аналізу виступив масив з 200 найбільш частотних лексем. Програми політичних об'єднань індексувалися за загальним списком ключових слів, які визначалися у межах частотних списків лексем кожної програми окремо серед найістотніших носіїв номінативної інформації - іменників та прикметників. Для кожного 3 них ураховувалася частота вживання. Частота семантичної групи виводилася як сумарна частота відповідних ключових слів.

За результатами проведеного дослідження зроблено такі висновки:

1. Статистика лексичної системи об'єктивно відображає підсвідомі настанови авторів передвиборчих програм i досить несподівано засвідчує принципово різне позиціонування політичних об'єднань, що пройшли до Верховної Ради за результатами виборів 2002 р.

Так, наприклад, концепти «конфлікт» та «капітал» характерні лише для БЮТ (Блок Юлії Тимошенко), а в інших партіях відсутні зовсім, причому концепт «конфлікт» для БЮТ є домінуючим.

Концепт «сільськогосподарський» характерний тільки для НАПУ (Народної аграрної партії України); у програмах інших політичних об'єднань він відсутній.

Концепт «влада» посідає в програмах політичних об'єднань такі місця: «Наша Україна» - друге (після концепту «Україна»); СПУ та БЮТ - сьоме; ТУ восьме; КПУ - тринадцяте, УРП - П'ятнадцяте; НРУ - дев'ятнадцяте, ПР двадцяте. В програмах інших політичних об'єднань цей концепт відсутній.

Щодо концепту «право» одержано такі результати:

КПУ - сьоме; СДПУ(о) - дванадцяте; НРУ - чотирнадцяте; БЮТ п’ятнадцяте; ПР - вісімнадцяте; НДП - двадцяте. В програми решти об'єднань концепт «право» не входить.

Певний подив викликала відсутність серед 200 найчастотніших слів у передвиборчих програмах всіх політичних об'єднань концептів «Бог», «любов», «щастя», «совість», «порядність» тощо. Такі лакуни є доволі красномовними і свідчать про цілковиту поляризацію підходів політичних об'єднань у розробленні гуманітарного концептуального поля.

2. Лексичний склад передвиборчих програм політичних об'єднань, одержаний за «слабким» критерієм (ранг 1), відчутно корелює практично для всіх аналізованих об'єктів (дані семантико-статистичного аналізу див. у табл. 22.222.6). Це пояснюється спільністю предметної галузі та, певною мірою, жанром аналізованих документів. Водночас спорідненість відповідних текстів за «середнім» критерієм (ранг 2) є несподівано невисокою, а за «сильним» критерієм (ранг 3) - узагалі незначною. Це свідчить або про відносно самостійне розроблення суб'єктами виборчого процесу своїх передвиборчих програм, або про досить серйозне та свідоме їхнє редагування. 3 одержаної інформації можна зробити ще й такий непрямий висновок: спектр політичних партій та блоків, що активно діяли в Україні в 2004 році, не випадковий. 
3 табл. 22.6, де наведено дані інтегральної кореляції текстів передвиборчих програм, можна зробити висновок, що в змістовому плані найретельніше було опрацьовано програму СДПУ(о). Дані по КПУ, можливо, не є показовими, оскільки на офіційному сайті цієї партії текст передвиборчої програми було наведено в скороченому варіанті. Програми НДП, УРП «Собор», блоків «Наша Україна», БЮТ та НАПУ мали би більш змістову компоненту за умови їхнього доопрацювання.

3. Семантичний аналіз дозволяе зробити детальніші висновки стосовно задекларованого партіями позиціонування в суспільно-політичному просторі України (табл. 22.2).

Дані цього аналізу переконують, що всі політичні об’єднання віддавали перевагу суто політичним питанням і значно меншою мірою - наріжним потребам громадян та соціальних спільнот. Це випливає зі значного домінування семантичних полів «держава й суспільство» та «політичні партії» порівняно 3 семантичними полями «охорона довкілля», «наука й культура», «освіта», «медична допомога», «пенсійне забезпечення» тощо. У семантичному полі «економіка» домінують ЛСГ «власність», «ринок» та «реформа», що є цілком зрозумілим у контексті перерозподілу власності та приватизаційних процесів в Україні того часу. Також викликало подив відносно низьке представлення ЛСГ «технологія», «сільське господарство» (за винятком НАПУ).

Таблиця 22.7. Відносна частота відображення тематичних рубрик у передвиборчих програмах політичних об'єднань

\begin{tabular}{|c|c|c|c|c|c|c|c|c|c|c|c|c|c|}
\hline & УРПС & СДПу & HPY & нДП & НАПУ & Ty & CПI & 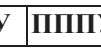 & \begin{tabular}{|l|l|}
$\mathbf{I}$ & ПР \\
\end{tabular} & \multicolumn{2}{|c|}{ КПУ } & HУ & БЮТ \\
\hline \multicolumn{14}{|c|}{1 Правова держава } \\
\hline Громадянство & 453 & 423 & 507 & 383 & 507 & 612 & 26 & 337 & 496 & \multicolumn{2}{|c|}{346} & 898 & 653 \\
\hline $\begin{array}{l}\text { Національне } \\
\text { законодавство }\end{array}$ & 1446 & 433 & 1059 & 450 & 507 & 338 & 176 & 754 & 466 & \multicolumn{2}{|c|}{346} & 154 & 653 \\
\hline Оборона & 452 & 510 & 677 & 433 & 443 & 325 & 486 & 438 & 495 & & 807 & 358 & 93 \\
\hline $\begin{array}{l}\text { Місцеве само- } \\
\text { врядування }\end{array}$ & 1130 & 422 & 669 & 948 & 474 & 377 & 269 & 459 & 177 & \multicolumn{2}{|c|}{230} & 588 & 466 \\
\hline $\begin{array}{l}\text { Зовнішня } \\
\text { політика }\end{array}$ & 452 & 456 & 325 & 466 & 379 & 195 & 14 & 303 & 510 & \multicolumn{2}{|c|}{115} & 590 & 372 \\
\hline $\begin{array}{l}\text { Права, свободи } \\
\text { обов'язки } \\
\text { громадян }\end{array}$ & 876 & 477 & 279 & 482 & 379 & 442 & 384 & 325 & 465 & & 115 & 429 & 466 \\
\hline Україна & 1415 & 851 & 3324 & 1200 & 2538 & 1928 & \begin{tabular}{l|l|}
8 & 121 \\
\end{tabular} & \begin{tabular}{l|l}
18 & 139 \\
\end{tabular} & \begin{tabular}{l|l}
6 & 162 \\
\end{tabular} & \multicolumn{2}{|c|}{1154} & 1848 & 1120 \\
\hline $\begin{array}{l}\text { Політичні } \\
\text { партії }\end{array}$ & 3090 & 828 & 2925 & 1899 & 4347 & 1159 & \begin{tabular}{l|l}
9 & 170
\end{tabular} & $97 \quad 130$ & 9249 & \begin{tabular}{l|l}
97 & 19
\end{tabular} & 1961 & 948 & 652 \\
\hline $\begin{array}{l}\text { Суспільні } \\
\text { відносини }\end{array}$ & 539 & 584 & 335 & 533 & 380 & 664 & 687 & 608 & 601 & 692 & 924 & & 653 \\
\hline $\begin{array}{l}\text { Держава і } \\
\text { суспільство }\end{array}$ & 4137 & 3472 & 4460 & 4063 & 3199 & 957 & 3472 & 3663 & 4296 & 4191 & 4256 & & 3450 \\
\hline $\begin{array}{l}\text { Загалом по } \\
\text { рубриці }\end{array}$ & 14442 & 8966 & 15237 & 10857 & 13216 & $\begin{array}{l}1006 \\
2\end{array}$ & 8857 & 9682 & 13376 & 10072 & 10993 & \multicolumn{2}{|c|}{\begin{tabular}{|l|l|}
3 & 8579
\end{tabular}} \\
\hline \multicolumn{14}{|c|}{2 Охорона довкілля } \\
\hline
\end{tabular}




\begin{tabular}{|c|c|c|c|c|c|c|c|c|c|c|c|c|}
\hline $\begin{array}{l}\text { Загалом по } \\
\text { рубриці }\end{array}$ & 170 & 77 & 54 & 100 & 412 & 52 & 177 & 213 & 75 & & 51 & \\
\hline \multicolumn{13}{|c|}{3 Духовний розвиток суспільства } \\
\hline $\begin{array}{l}\text { Наука, } \\
\text { культура }\end{array}$ & 1076 & 671 & 531 & 800 & 569 & 104 & 238 & 449 & 886 & 1038 & 178 & 652 \\
\hline Освіта & 425 & 200 & 144 & 25 & 222 & 208 & 125 & 112 & 135 & 115 & 77 & 28 \\
\hline $\begin{array}{l}\text { Загалом по } \\
\text { рубриці }\end{array}$ & 1501 & 871 & 675 & 1050 & 791 & 312 & 363 & 561 & 1021 & 1163 & 255 & 680 \\
\hline \multicolumn{13}{|c|}{4 Соціальний захист } \\
\hline $\begin{array}{l}\text { Медична } \\
\text { допомога }\end{array}$ & 56 & 144 & 90 & 233 & 31 & 260 & 20 & 45 & 9 & 115 & 51 & \\
\hline $\begin{array}{l}\text { Гуманітарні } \\
\text { проблеми }\end{array}$ & 2493 & 2730 & 1701 & 1947 & 2472 & 3229 & 25 & 2676 & 2388 & 2190 & 1795 & \\
\hline Пенсії & 28 & 100 & 117 & 83 & 31 & 104 & 07 & 33 & 165 & & 25 & \\
\hline $\begin{array}{l}\text { Допомога } \\
\text { дітям } \\
\end{array}$ & 56 & 83 & 18 & & 31 & 247 & 31 & 22 & 60 & & 25 & 93 \\
\hline $\begin{array}{l}\text { Проблеми } \\
\text { молоді }\end{array}$ & 226 & 139 & 90 & 216 & 317 & 208 & 62 & 191 & 90 & 115 & 231 & 93 \\
\hline Сім'я & 141 & 178 & & 66 & 31 & 65 & 125 & 11 & 105 & & & \\
\hline \begin{tabular}{|l} 
Праця, \\
зайнятість
\end{tabular} & 480 & 594 & 252 & 399 & 537 & 1224 & 72 & 538 & 480 & 346 & 153 & 1492 \\
\hline Добробут & 84 & 255 & 135 & 116 & 158 & 221 & 998 & 225 & 210 & 0 & 589 & 0 \\
\hline $\begin{array}{l}\text { Демографічні } \\
\text { проблеми }\end{array}$ & 198 & 306 & 172 & 166 & 222 & 169 & 239 & 270 & 150 & & 179 & 93 \\
\hline $\begin{array}{l}\text { Загалом по } \\
\text { рубриці }\end{array}$ & 3762 & 4529 & 2575 & 3226 & 3830 & 5727 & 4230 & 4011 & 3738 & 2766 & 3048 & 3449 \\
\hline \multicolumn{13}{|c|}{5 Економіка } \\
\hline Власність & 452 & 316 & 407 & 516 & 539 & 156 & 374 & 325 & 210 & 576 & 255 & 119 \\
\hline Виробництво & 2006 & 2353 & 2184 & 2677 & 1867 & 2016 & 2338 & 2706 & 2252 & 1611 & 2461 & 2703 \\
\hline $\begin{array}{l}\text { Податкова } \\
\text { система }\end{array}$ & 226 & 149 & 207 & 199 & 126 & 78 & 93 & 281 & 210 & 115 & 127 & 746 \\
\hline Реформа & 85 & 239 & 289 & 233 & 158 & 208 & 31 & 90 & 150 & & 102 & \\
\hline Ринок & 255 & 383 & 280 & 582 & 126 & 208 & 83 & 382 & 285 & & 154 & 93 \\
\hline $\begin{array}{l}\text { Сільське } \\
\text { господарство }\end{array}$ & 84 & 166 & 333 & 232 & 2538 & 65 & 197 & 88 & 270 & 230 & 179 & 373 \\
\hline $\begin{array}{l}\text { Фінансова } \\
\text { політика }\end{array}$ & 169 & 265 & 288 & 283 & 62 & 240 & 123 & 381 & 240 & & 332 & 186 \\
\hline Технологія & 28 & 38 & 108 & 66 & 31 & 65 & 72 & 33 & 90 & & 154 & \\
\hline $\begin{array}{l}\text { Загалом по } \\
\text { рубриці }\end{array}$ & 3305 & 3909 & 4096 & 4888 & 5447 & 3036 & 3311 & 4286 & 3707 & 2532 & 3764 & 5220 \\
\hline
\end{tabular}

Показники в таблиці становлять частоту, помножену на 105. Рядки таблиці репрезентують семантичні групи із зазначенням тематичного поля, стовпчики програми політичних об’єднань. На їхньому перетині подається інформація про частоту вживання кожної семантичної групи в конкретному тексті. Ця інформація може інтерпретуватися як показник того, скільки уваги було приділено зазначеній проблемі в передвиборчій програмі. Заповнені клітини інформують про те, які саме проблеми розглядались у програмах. 


\section{ВИСНОВКИ}

1. Попри очевидний розвиток галузі лінгвістичних експертиз, на сьогодні не існує іiі впорядкованого та систематизованого опису, що включає не тільки досягнення, більш-менш прийнятні результати, а й невдалий досвід. Вимоги до оформлення наукових робіт не передбачають опис «провальних» експериментів і їх немає в жодній публікації. Через складність верифікації результатів, їхня достовірність - на совісті дослідників, чим деякі користуються, не обтяжуючи себе відповідальністю, породжуючи в суспільстві (а отже - серед потенційних замовників) міф про можливості лінгвістичних експертиз.

2. Завдання авторознавчої експертизи полягає у встановленні мовленнєвої особистості на основі рис (ознак), проявлених в тексті та переході від цієї «віртуальної» особистості до реальної особи посередництвом знання про закономірності, межі стійкості та варіабельності індивідуальних навичок писемного мовлення. Створення такого знання можливе за умов проведення масштабних соціолінгвістичних, психологічних, психолінгвістичних, лінгвопсихологічних та інших досліджень єдиним фронтом, під загальним керівництвом, що практично $є$ нездійсненним без виходу на загальнодержавний рівень, враховуючи вартість та тривалість таких досліджень, розрізненість та фінансову конкуренцію недержавних експертних установ.

3. Іншою проблемою галузі є дефіцит (а більш правильно сказати відсутність) кадрів із підтвердженою кваліфікацією документом - жоден 3 вітчизняних лінгвістичних вишів не готує лінгвістів-експертів i, наскільки нам відомо, такого документа поза системою Міністерства юстиції України не існує.

Зазначимо, що в загальномовному значенні диплом як диференціальна ознака експерта не фігурує:

Експерт - фахівець, що робить експертизу (СУМ-11. Том 2, 1972. С. 462);

Експерт - фахівець у будь-якій галузі, що проводить експертизу та здатний на підставі своїх знань та досвіду надавати кваліфіковану консультацію (Тлумачний словник української мови online. URL: http://eslovnyk.com/експерт);

Expert - a person who is very knowledgeable about or skilful in a particular area (English Oxford Living Dictionaries);

Expert - a person who has special skill or knowledge in some particular field; specialist; authority (URL: http://www.dictionary.com/browse/expert);

Эксперт - сведущее лицо, специалист, привлекаемый для того, чтобы высказать свое мнение (Толковый словарь Д. Н. Ушакова); 
Эксперт -a, м. Специалист, дающий заключение при рассмотрении какого-н. вопроса. (Толковый словарь русского языка Ожегова online. URL: http://www.ozhegov.com/words/40618.shtml).

У найкращому, на наш погляд, визначенню поняття «експерт», що належить фахівцеві в галузі штучного інтелекту та експертних систем П. Й. Джонсону, також немає жодного слова про диплом чи посвідчення: «Експерт - це людина, яка завдяки навчанню та досвіду може робити те, що ми всі, інші люди, робити не вміємо; експерти працюють не просто професійно, але й впевнено та ефективно. Експерти мають величезні знання та користуються різними прийомами для застосування своїх знань до проблем та завдань; вони також вміють швидко досягати головного й добре вміють розпізнавати в проблемах, 3 якими стикаються, приклади тих типових проблем, з якими вони вже знайомі. В основі поведінці експертів лежить сукупність практично застосованих знань, яку ми будемо називати компетентністю. Тому розумно припустити, що експерти - це ті люди, до яких треба звернуться, коли ми бажаємо проявити компетентність, що уможливлює таку поведінку, як у них». ${ }^{188}$

Але навіть очевидні та переконливі результати, отримані, наприклад, громадськими активістами, жодна інстанція розглядати не буде. Громадяни не визнаються правомочними проводити лінгвоекспертні дослідження та поширювати отримані ними результати, навіть володіючи значущою для експертизи інформацією та навичками. Першою реакцією незадовільними результатами експертизи є гнів, другою та наступними - напад - організований тиск на експертів представників владних або вищих структур, про що прийнято замовчувати. Багаторічна боротьба Всеукраїнської громадської організації «Українська федерація вчених», групи «Дисергейт», інших об’єднань науковців та окремих осіб проти перекручування фактів, плагіату та академічного шахрайства серед посадовців та наближених осіб, що своєю безнадійністю та нескінченністю нагадує «працю» коринфського царя Сізіфа, тому яскраве свідчення.

4). Як зазначалося в иьому розділі та усіляко декларується в численних підручниках, посібниках, інструкиіях, основними вимогами до експертного висновку є однозначність, достовірність, надійність та доказовість. Жодного разу не згадується така важлива характеристика експертного висновку, як зрозумілість для пересічного реципієнта. За нашими спостереженнями, експертний висновок повинен бути орієнтований, наскільки це можливо, на непідготовленого (пересічного) читача, але при цьому експерти не повинні опускатися до примітивних пояснень. Також експерти завжди повинні зважати на можливу колізію їхнього висновку з висновками інших експертів, до яких може звернутися ініціатор експертизи чи його опонент, адже така ситуація не має розв'язання в

${ }^{188}$ Цит. за Уотермен Д. Руководство по экспертным системам. Пер. с англ. Москва: Мир, 1989. $388 \mathrm{c}$. 
юридичному сенсі, хоча в науковому є доволі зрозумілою - різні методики та підходи дають різний результат.

На сьогодні теорія, методологія та практика лінгвістичних експертиз є достатньо розвиненими лише для невеликих за обсягом текстів. Що стосується експертизи текстових масивів (а саме в цьому напрямку буде відбуватись розвиток галузі), через низький рівень автоматизації лінгвоекспертної діяльності жодна спеціалізована експертна або наукова установа не візьметься за виконання такого завдання. Наведені приклади застосування корпусних та інших комп'ютерних технологій в лінгвоекспертній діяльності $\epsilon$ результатом піонерських розробок, виконаних окремими науковими колективами.

Серед наукових публікацій у галузі лінгвістичних експертиз досі дуже незначна кількість присвячена застосуванню комп'ютерних технологій, наприклад, для автоматичного формування висновку лінгвістичної експертизи та додатків (ілюстративної частини), трудомісткість оформлення яких стосовно великих за обсягом текстів перевищує трудомісткість виконаних досліджень. Низька автоматизація перевірки посилань, цитат, пошуку можливих джерел запозичень, квантифікації результатів експертизи призводять до помилок експертів. 


\section{ДОДАТОК А}

\section{Лінгвоекспертна діяльність Українського мовно- інформаційного фонду НАН України в публікаціях. \\ Розвиток теорії, методики та програмних засобів}

\section{5}

1. Широков В. А., Сидоренко О. О. Наукові засади лінгвістичної експертизи політичних та правових документів: постановка проблеми. Мовознавство. № 2, 2005. С. 18-31.

2. Широков В. А. Ющенко С. С. Підходи до проектування інформаційної системи для представлення протиріч у законодавчих документах. Праці Луганського відділення міжнародної академії інформатизації. № 2 (11). Луганськ: Східноукраїнський університет імені Володимира Даля, 2005. С. 106-108.

3. Ющенко С. С. Експертиза законодавчих актів у світлі інформаційних технологій. Інтегровані інформаційні технологї та системи (IITC-2005). Матеріали наук.-практ. конф. молодих учених та аспірантів (Київ, 26-28 жовтня 2005 р.). Київ. НАУ, 2005. С. 119-121.

4. Шкурко В. В. Технологические аспекты построения системы локализации и анализа противоречий в законодательных документах. Інтегровані інформаційні технології та системи (IITC-2005). Матеріали наук.-практ. конф. молодих вчених та аспірантів (Київ, 26-28 жовтня 2005 р.). Київ. НАУ, 2005. С. 113-115.

5. Широков В. А., Бугаков О. В., Грязнухіна Т. О. та ін. Корпусна лінгвістика. Київ: Довіра, 2005. 471 с.

\section{6}

6. Ющенко С. С. Некоторые концептуальные и методологические проблемы распознавания квазиколлизий. Горизонти прикладної лінгвістики та лінгвістичних технологій MegaLing'2006. Тези міжнар. наук.-практ. конф. (Україна, Крим, Партеніт, 20-27 вересня 2006 р.). Сімферополь: Таврійс. нац. ун-т ім. В.І. Вернадського, 2006. С. 190-191.

7. Шкурко В. В., Ющенко С. С. Концептуальні засади та системотехнічні підходи до проектування системи пошуку протиріч. Зб. наук. праць Вісник Національного авіаційного університету. № 3. Київ: НАУ, 2006. С. 212-215.

\section{7}

8. Шкурко В., Ющенко С. Підходи до формування та впорядкування термінології законодавства засобами комп'ютерних лінгвістичних технологій. Зб. наук. праць Вісник Національного університету «Львівська політехніка». Львів: Львівська політехніка. № 593, 2007. C. $79-86$.

9. Ющенко С. С. Інформаційно-правові системи: російський досвід. Радіоелектроніка. Інформатика. Управління. Наук. журнал. №1 (17). Запоріжжя: Запорізький національний технічний університет, 2007. С. 119-123.

10. Ющенко С. С. Относительно экспликации коллизиогенных контекстов в нормативноправовых актах. Горизонти прикладної лінгвістики та лінгвістичних технологій MegaLing'2007. Тези доп. міжнар. наук.-практ. конф. (Україна, Крим, Партеніт, 24-28 вересня 2007 р.). Сімферополь: Таврійс. нац. ун-т ім. В. І. Вернадського, 2008. С. 317-318.
11. Любченко Т. П.,
Грязнухина Т. А.,
Широков В. А.
Автоматизированное редактирование украинского текста в системе многоязычного машинного перевода. Горизонти прикладної лінгвістики та лінгвістичних технологій MegaLing'2007. Тези доп. міжнар. наук.практ. конф. (Україна, Крим, Партеніт, 24-28 вересня 2007 р.), Сімферополь: Таврійс. нац. ун-т ім. В. І. Вернадського, 2008. С. 111-112.

\section{8}

12. Сидоренко О., Широков В., Ющенко С. Підходи до побудови інформаційних технологій логіко-лінгвістичного моніторингу нормативно-правових актів. Людина. Комп'ютер. 
Комунікація. Зб. наук. праць. Львів: Національний університет «Львівська політехніка», 2008. C. $175-177$.

13. Ющенко С. С., Шкурко В. В., Широков В. А. Формирование экспериментального терминологического массива законодательства: цель и средства. Горизонти прикладної лінгвістики та лінгвістичних технологій MegaLing'2008. Тези доп. міжнар. наук.-практ. конф. (Україна, Крим, Партеніт, 22-28 вересня 2008 р.). Сімферополь: Таврійс. нац. ун-т ім. В. I. Вернадського, 2008. С. 295-297.

14. Ющенко С. К вопросу о коллизиях правовых текстов. Прикладна лінгвістика та лінгвістичні технології. Зб. наук. праць. НАН України, Укр. мовно-інформ. фонд, Таврійс. нац.. ун-т ім. В. І. Вернадського, Ин-т. рус. яз. им. В. В. Виноградова РАН /за ред. Ю. Д. Апресяна [та ін.]. Київ: Довіра, 2008. С. 472-483.

\section{9}

15. Ющенко С. С. К вопросу о разметке нормативно-правовых актов. Горизонти прикладної лінгвістики та лінгвістичних технологій MegaLing'2009. Тези доп. міжнар. наук.практ. конф. (Крим, Партеніт, 22-28 вересня 2009 р.). Сімферополь: Таврійс. нац.. ун-т ім. В. I. Вернадського. 2008, С. 124-125.

16. Ющенко С. С. К вопросу о проектировании интегрированной лексикографической системы «Тезаурус Верховной Рады Украины». Прикладна лінгвістика та лінгвістичні технології. Зб. наук. праць. / за ред. В. А. Широкова. Київ: Довіра, 2009. С. 506-515.

17. Ющенко С. С. Пріоритетні напрямки мовно-інформаційного забезпечення законотворчих процесів. Прикладна лінгвістика 2009: проблеми і рішення. Тези Всеукр. наук.метод. конф. студ. та молодих науковців. Національний ун-т кораблебудування ім. адмірала Макарова (Миколаїв, 21-22 травня 2009 р.). Миколаїв: НУК, 2009. С. 147-150.

18. Афанасьєва О. Семантичні девіації в текстах нормативно-правових актів України. Прикладна лінгвістика та лінгвістичні технології. Зб. наук. праць /за ред.:В. А. Широкова. Київ: Довіра, 2009. С. 3-9.

19. Грязнухіна Т., Устимець Т., Широков В. Операційне визначення критерію семантичної подібності синонімів. Прикладна лінгвістика та лінгвістичні технології. Зб. наук. праць / за ред. В. А. Широкова. Київ: Довіра, 2010. С. 42-57.

20. Крыгин М. Средства статистического анализа в системе лингвистической экспертизы. Прикладна лінгвістика та лінгвістичні технології. Зб. наук. праць / за ред. В. А. Широкова. Київ: Довіра, 2010. С. 124-134.

21. Rabulets A. System Engineering Principles of Virtual Linguistic Laboratories. Organisation and Development of Digital Lexical Resources. Proceeding of Mondilex Second Open Workshop. Kyiv, 2009. P. 18-23.

\section{0}

22. Крыгин М., Широков В. Корпусные технологии при проведении лингвистических экспертиз. Прикладна лінгвістика та лінгвістичні технології. Зб. наук. праць. НАН України, Укр. мовно-інформ. фонд [та ін.] / редкол.: Л. П. Крисін [та ін.]. Київ: Довіра, 2010. С. 130-140.

23. Ющенко С. Концепция рубрикатора языковых девиаций в актах первичного законодательства Украины. Прикладна лінгвістика та лінгвістичні технології. Зб. наук. праць. НАН України, Укр. мовно-інформ. фонд [та ін.] / редкол.: Л. П. Крисін [та ін.]. Київ: Довіра, 2010. C. 234-242.

24. Ющенко С., Шкурко В. До проблеми побудови лексикографічного процесора, орієнтованого на первинні законодавчі акти України. Людина. Комп’ютер. Комунікація: Зб. наук. праць / за ред. Ф. С. Бацевича. Львів: Національний університет «Львівська політехніка», 2010. C. 104-106.

25. Ющенко С. С., Шкурко В. В. Об одном прикладном аспекте информационных технологий в сфере логико-лингвистических экспертиз проектов первичных законодательных актов Украины. Горизонти прикладної лінгвістики та лінгвістичних технологій. Зб. наук. праць. Сімферополь: Центр когнітивної та прикладної лінгвістики Таврійс. нац.. ун-та ім. B. I. Вернадського. 2010. URL: http://ru.convdocs.org/docs/index-206114.html. 
26. Ющенко С. Концепция рубрикатора языковых девиаций в актах первичного законодательства Украины. Прикладна лінгвістика та лінгвістичні технології. Зб. наук. праць. редкол.: Л. П. Крисін [та ін.]. НАН України, Укр. мовно-інформ. фонд [та ін.]. Київ: Довіра, 2010. C. 234-242.

27. Ющенко С., Шкурко В. До проблеми побудови лексикографічного процесора, орієнтованого на первинні законодавчі акти України. Людина. Комп’ютер. Комунікація. Зб. наук. праць / за ред. Ф. С. Бацевича. Львів: Національний університет «Львівська політехніка», 2010. С. 104-106.

\section{1}

28. Грязнухина Т. А., Бугаков О. В., Шкурко В. В, Любченко Т. П. Моделирование текстовых коллокаций в лексикографической системе украинского языка. Прикладна лінгвістика та лінгвістичні технології. Зб. наук. праць / за ред. В. А. Широкова. Київ: Довіра, 2012. C. $120-139$.

29. Любченко Т. П. Лексикографічні системи граматичного типу та їх застосування в засобах автоматизованого опрацювання мови. дис. канд. техн. наук: 10.02.21. Київ: НБУ імені В. I. Вернадського, 2011. 294 с.

30. Ющенко С. С. Індуктивний девіаційний аналіз законодавчих текстів. Studia linguistica et juridica. Зб. наук. праць. Вип. 1. / відп. ред. О. І. Іліаді. Кіровоград: Кіровоградський юридичний інститут, 2011. С. 151-158.

31. Ющенко С. С. И/ИЛИ в текстах законодательных актов (корпусное исследование). Горизонти прикладної лінгвістики та лінгвістичні технологї MegaLing 2011. Тези Міжнар. наук. конф. (Україна, Крим, Партеніт 12-16 травня 2011). / за ред. В. А. Широкова, С. С. Дикарєвої. Український мовно-інформаційний фонд НАН України, Таврійський національний університет ім. В. I. Вернадського. Сімферополь: ДИАЙПИ, 2011. URL: http://www.ulif.

org.ua/materials/m2012/Jushenko s416-423.pdf).

\section{2}

32. Грязнухіна Т. О., Я Якименко К. Н Эксплицитное представление семантической информации в электронном толковом словаре украинского языка (синонимическая и паронимическая параметризация). Прикладна лінгвістика та лінгвістичні технології MEGALING-2012. Зб. наук. праць / за ред. В. А. Широкова. Київ: Довіра, 2013. С. 79-90.

33. Ющенко С. С. Когнитивно-информативные аспекты ложных цитат. Доп. III Міжнар. наук. симпозіуму Ретроспектива філології в інформаційному суспільстві знань RETRO'2012. (Україна, Крим, Партеніт 11.06 - 16.06.2012 р.) / за ред. С. С. Дікаревої, О. Г. Чернявської. Таврійський національний університет ім. В. І. Вернадського. Сімферополь: Таврійс. нац. ун-т ім. В. І. Вернадського. С. 52-53.

34. Ющенко С. С. Стилистические приемы политической антирекламы избирательной кампании в Верховную Раду Украины 2012 года. Прикладна лінгвістика та лінгвістичні технології MEGALING-2012. Зб. наук. праць / за ред. В. А. Широкова. Київ: Довіра, 2013. C. 241-252.

35. Ющенко С. С. Лінгвістичні недоліки Закону України «Про вибори народних депутатів України» та їх наслідки для керівництва дільничних виборчих комісій. Мовнотермінологічні проблеми сучасного законодавства. Тези наук. доповідей та повідомлень на конф. 5 грудня 2012 року та круглих столах 24 та 29 січня 2013 року. Національний університет «Києво-Могилянська академія». Серія «Правничі науки». Київ: НаУКМА, 2013. С. 181-185. URL: https://law.univ.kiev.ua/ua/pro-nas-u-zmi/1628.

37 Потапова Е. В. Модель лингвистической онтологии предметной области с нечеткими семантическими состояниями терминов. Бионика интеллекта. № 2 (79). Харьков: ХНУРЭ. 2012, C .95-102.

38. Потапова Е. В. Широков В. А. Онтология предметной области как лексикографическая система особого типа. Казанская наука. № 12. Казань. Казанский Издательский Дом, 2012. С. 209-213. 


\section{3}

39. Каращук А. Я., Ющенко С. С. К вопросу о дискурсивной безопасности. Доп. IV міжнар. наук. симпозіуму RETRO'2013 Ретроспектива філологї в інформаційному суспільстві знань. (Україна, Крим, Партеніт, 11.06 - 16.06.2013). Сімферополь: Таврійс. нац. ун-т ім.. В. I. Вернадського, 2013.

URL: http://retro.crimea.edu/publications/2013_1 karaschuk_yuschenko.pdf.

40. Ющенко С. С. Кавычки в имидж-понижающих информационно-политических текстах. Доп. міжнар. конф. Горизонти прикладної лінгвістики та лінгвістичних технологій MegaLing'2013 (Київ, 19-22 листопада 2013 р.). URL: http://megaling.ulif.org.ua/tezi-2013rik/yuschenko-svetlana-sergeevna-kavyichki-v-imidzh-ponizhayuschih-informatsionno-politicheskihtekstah.html.

41. Ваколюк Т. В., Комарницька О. І. Алгоритм нечіткого семантичного порівняння текстової інформації. Зб. наук. праць Військового інституту Київського національного університету імені Тараса Шевченка. № 39. Київ: КНУ, 2013. С. 163-168.

\section{4}

42. Ющенко С. С. Узагальнена типологія текстових колізій: підходи до побудови. Збірник Наукові записки. Серія «Філологічні науки» (мовознавство). Вип. 128. Кіровоград: КДПУ ім. В. Винниченка, 2014. С. 274-279.

43. Ющенко С. С. Принципы коллизийного отношения естественно-языковых текстов. Прикладна лінгвістика та лінгвістичні технології MEGALING-2013. Зб. наук. праць / за ред. В. А. Широкова. Київ: Довіра, 2014.

44. Komarnytska O. I. Application of artificial intelligence models for content comparison of text information. Філологічні трактати. Вісник Сумського державного університету. Серія «Філологічні науки». Т. 6. № 3. Суми: СДУ, 2014. С. 100-106.

45. Комарницкая О. И. Метод латентно-семантического анализа нечеткой текстовой информации. Пограничная безопасность: теория и практика. Труды междунар. научно-практ. конф. (Минск, 17 января 2014 г.). в 3 ч. Ч. 2. Минск: ГУО «ИПС РБ», 2014. С. 285-288.

\section{5}

46. Ющенко С. С. Подходы к определению формы и мощности текстовых коллизий. Зб. наук. праць. Серія «Філологічні науки» (мовознавство). Кіровоград: КДПУ ім. В. Винниченка, 2015. URL: http://www.kspu.kr.ua/images/download-files/inmov/nz-136.pdf.

47. Ющенко С. С. Дискурс-аналитический поход к верификации информационноновостных материалов. Зб. наук. праць Таврійського національного університету імені B. I. Вернадського. Серія «Соціальні комунікації». Сімферополь: ТНУ ім. В. І. Вернадського, 2015.

48. Комарницька О. І. Моделі штучного інтелекту для порівняння текстової інформації за змістом. Лінгвістичні студії. Зб. наук. праць / за ред. А. П. Загнітка. Вип. 30. Донецький національний університет. Вінниця: ДонНУ, 2015. С. 135-139.

49. Ющенко С. С. Імпліцитне загальне заперечення в письмових веб-дискурсах. Наукові записки. Зб. наук. праць. Серія «Філологічні науки» (мовознавство). Вип. 130. Кіровоград: КДПУ ім. В. Винниченка. 2015. С. 665-670.

\section{6}

50. Грязнухина Т. А., Заика Н. М., Любченко Т. П., Широков В. А. Интегрированная лексикографическая система как инструмент автоматизированного формирования новых электронных словарей и как база лингвистических исследований в области лексической семантики. Актуальные проблемы современной прикладной лингвистики. Сб. научн. статей. Минск: Минский гос. лингв. университет, 2016. С. 221-225.

51. Ющенко С. С. Численная оценка коллизийности текстов. Актуальные проблемы современной прикладной лингвистики. Сб. научн. статей. Минск: Минский гос. лингв. университет, 2016. С. 183-188. 
52. Ющенко С. С. Подходы к определению формы и мощности текстовых коллизий. Наукові записки. Зб. наук. праць. Серія «Філологічні науки» (мовознавство). Вип. 136. Кіровоград: КДПУ ім. В. Винниченка. 2015, С. 214-220.

2017

53. Ющенко С. С. Экспликация заимствований в украинских научных текстах: актуальный экспертный опыт. Эксплицитное и имплицитное в языке и речи. Тезисы междун. научн. конф. (Беларусь, Минск 10-11 мая 2017 г.) / редкол. Л. М. Лещева (отв. ред.) [и др.]. Минск: Минский гос. лингв. университет, 2017. С. 302-305.

54. Ющенко С. С. Комп'ютерні інструменти лінгвістичних експертиз. Мовний простір слов'янського світу. Тези наук.-практ. конф. молодих вчених. (Київ, Національний університет «Києво-Могилянська академія», 23 травня 2017 р.). Київ: НаУКМА, 2017.

55. Ющенко С. С. Логіко-лінгвістична експертиза наукових текстів. Словники Украӥни: паперові та електронні. Симпозіум (Київ, 16 травня 2017 р.); доповідь у рамках проекту «Наукова Світлиця». TOB «Знання». Київ, 2017. URL: https://lecbank.jimdo.com/; https://www.youtube.com/watch?v=gC8jALPh7qw). 


\section{ЛITEPATУPA}

1. Указ Президента України «Про розвиток Національної словникової бази» від 7 серпня 1999 року № 967/99 [Електронний ресурс]. - URL: http://zakon3.rada.gov.ua/laws/show/967/99. Назва з екрана.

2. Алексеева И. С. Профессиональный тренинг переводчика. - Санкт-Петербург : Союз, 2001. - С. 258-259.

3. Андрющенко В. М. Концепция и архитектура машинного фонда русского языка. Москва : Наука, 1989. - 200 с.

4. Аникина Н. В. Формализация семантики предлогов с помощью тезауруса / Н. В. Аникина, Ю. И. Горбунов// Автоматическая переработка текста методами прикладной лингвистики. - Кишинев : Кишинев. политехн. ин-т, 1977. - С. 57.

5. Аннотированный корпус русских текстов: концепция, инструменты разметки, типы информации [Электронный ресурс] / И. М. Богуславский и др. // Компьютерная лингвистика и интеллектуальные технологии: «Диалог-2000»: Тр. Междун. семинара по компьютерной лингвистике и еe приложениям, 2000. - URL : http://www.dialog21.ru/digest/2000/articles/boguslavsky/ . - Загл. с экрана.

6. Аполлонская Т. А. Устранение омонимии при АПТ / Т. А. Аполлонская, Е. Ф. Марашлец, А. Н. Попескул // Инженерная лингвистика и оптимизащия преподавания иностранных языков в вузе. - Ленинград : ЛГПИ, 1983. - С. 92-102.

7. Астафьева Н. И. Современный русский язык: Служебные части речи. Модальные слова. Междометия / Н. И. Астафьева, И. А. Киселев, З. Ф. Кравченко. - Минск : Вышэйшая школа, 1971. - $80 \mathrm{c}$.

8. Баранов А. Н. Введение в прикладную лингвистику. - Москва : Эдиториал УРСС, 2001. - C. 121-128.

9. Баранов А. Н. Лингвистическая экспертиза текста: теория и практика : учеб. пос. / А. Н. Баранов. - 2-е изд. - Москва : Флинта: Наука. 2009. - 592 с.

10. Баранов А.Н. «Динамический корпус текстов» как новая технология прикладной лингвистики / А. Н. Баранов, М. Н. Михайлов, Г. О. Сидоров // «Диалог-98» : Тр. междунар. семинара по компьютерной лингвистике и ее приложениям. - Сер. 2. - Т. 2. - 1998. - С. 58-60.

11. Баранов А. Н. «Корпусная лингвистика» в Германии (опыт аналитического изучения) / А. Н. Баранов, Д. О. Добровольский // Вестник МГУ. Сер.: Иностранные языки. 1998. - № 1. - С. 64-70.

12. Баранов А. Н. Проблемы репрезентативности корпуса данных (на примере политической метафоры) // Международный семинар «Диалог 2001». - Москва, 2001. С. $112-114$.

13. Белокриницкая С. С. Различные типы омонимии и способы их различия при машинном переводе // Вопросы языкознания. -1960. - № 2. - С. 97-102.

14. Бомарше П. Безумний день або Весілля Фігаро. Комедія на 5 дій / П. Бомарше; пер. 3 франц. С. Тобілевич; за ред. І. Кочерги. - Київ : Мистецтво, 1951. - С. 96-99.

15. Бондаренко В. С. Предлоги в современном русском языке / В. С. Бондаренко. Москва : Госучпедиздат, 1961. - 76 с.

16. Бугаков О. В. Автоматична ідентифікація складених прийменників в українському тексті / О. В. Бугаков // Актуальні проблеми украӥнської лінгвістики: теорія і практика: зб. наук. праць. - Вип. 11. - Київ : ВПЦ «Київський університет», 2005. - С. 42-48.

17. Бугаков О. В. Аналіз граматичної омонімії прийменників у мові й у тексті/ О. В. Бугаков // Мовознавство. - 2004. - № 5-6. - С. 87-98.

18. Бугаков О. В. Зони прийменникових зв'язків у синтаксичній структурі українського речення / О. В. Бугаков // Мовознавство. - 2005. - № 5. - С. 75-87. 
19. Бугаков О. В. Усунення граматичної омонімії прийменників в українському тексті / О. В. Бугаков // Мовні і концептуальні картини світу: зб. наук. пр. - Київ : Видавничий Дім Дмитра Бураго, 2004. - Вип. 11. Кн. 1. - С. 50-53.

20. Бугаков О. В. Функціонування складених прийменників у тексті / О.В.Бугаков // Вісник Львівського університету. Серія філологічна. - Вип. 34. Ч. 1. - Львів : ЛНУ ім. І. Франка, 2004. - С. 333-339.

21. Виноградов В. В. Об омонимии и смежных явлениях / В. В. Виноградов // Исследования по русской грамматике. - Москва : Наука, 1975. - С. 295-312.

22. Вихованець I. Р. Прийменникова система української мови / I. Р. Вихованець. - Київ : Наукова думка, 1980. - 286 с.

23. Герд А. С. Вступне слово на міжнародній конференції [Електронний ресурс] / А. С. Герд //Корпусная лингвистика. - Київ,2004. - URL: www.phil.pu.ru/news/kllbd/corpling.htm. - Назва з екрану.

24. Грязнухина Т. А. Анализ предложных связей в научном тексте / Т. А. Грязнухина. Киев : Наукова думка, 1985. - 148 с.

25. Грязнухина Т. А. Электронная версия грамматического словаря русского языка (А. А. Зализняк) как инструмент автоматического морфологического анализа русского текста / Т. А. Грязнухина, Т. П. Любченко, А. Г. Рабулец // Корпусная лингвистика и лингвистические базы данных : доклады научн. конф. - Санкт-Петербург : Изд-во С.-Петерб. ун-та, 2002. С. 63-70.

26. Декарт Р. Рассуждение о методе. Метафизические размышления. Начала философии / Р. Декарт. - Луцк : Вежа, 1998. - 302 с.

27. Демська О. М. Словник омонімів української мови / О. М. Демська, I. М. Кульчицький. - Львів : Фенікс, 1996. - 224 с.

28. Загнитко А. П. Предлог в морфологическом пространстве украинского языка (синхронно-контрастивные наблюдения) / А. Загнитко // Вестник Московского университета. Сер. 9. Филология. - 2003. - № 3. - С. 92-106.

29. Захаров В. П. Чешский национальный корпус текстов: организация и способы использования / В. П. Захаров // Корпусная лингвистика и лингвистические базы данных : докл. научн. конфер. (РФ, Санкт-Петербург, 5 - 7 марта 2002 г.). - Санкт-Петербург, 2002. C. $72-79$.

30. Золотова Г. А. Синтаксический словарь: Репертуар элементарных единиц русского синтаксиса / Г. А. Золотова. - Москва : Наука, 1988. - 440 с.

31. Иорданская Л. Н. Автоматический синтаксический анализ. В 2 т. Т. 2 : Межсегментный синтаксический анализ / Иорданская Л. Н. - Новосибирск : Наука, 1967. $290 \mathrm{c}$.

32. Іваненко 3. I. Система прийменникових конструкцій адвербіального значення / 3. І. Іваненко. - Київ-Одеса : Вища школа, 1981. - 143 с.

33. Кисилев А. Н. Предварительное разрешение омографии как основа реализации соответствия между частями речи и членами предложения в системе АМП / А. Н. Кисилев // Омосемия и омография в естественных и машинных языках: сб. научн. тр. Дальневосточный науч. центр АН СССР. - Владивосток, 1986. - С. 150-159.

34. Коваленко А. Вероятностный морфологический анализатор (стеммер) [Электронный peсурс] / А. Коваленко. - URL : http://www.keva.ru/stemka/stemka.html. - Загл. с экрана.

35. Колодяжний А. С. Прийменник: Матеріали до лекцій з курсу сучасної української літературної мови / А. С. Колодяжний. - Харків : Вид-во Харків. ун-ту, 1960. - 165 с.

36. Колшанский Г. В. Контекстная семантика / Г.В.Колшанский. - Москва : Наука, 1980. $-150 \mathrm{c}$.

37. Копиленко О. Мовні проблеми в український політичній думці та законодавстві 1917-1920 pр. / О. Копиленко // Право Украӥни. - 1998. - № 9. - С. 44-48. 
38. Копотев М. В. Неоднозначность и пути ее разрешения в в хельсинском аннотированном корпусе «ХАНКО» / М. В. Копотев //«Корпусная лингвистика - 2004» : тр. междунар. конф. - Санкт-Петербург : Изд-во С.-Петерб. ун-та, 2004. - С. 165-175.

39. Кочерган М. П. Слово і контекст: Лексична сполучуваність і значення слова / М. П. Кочерган. - Львів : Вища школа, 1980. - 184 с.

40. Кравченко С. П. До питання про мови юридичного закону та їі вплив на правову культуру суспільства / С. П. Кравченко //Актуальні проблеми держави і права : зб. наук. праць. - Одеса, 1998. - С. 56-94.

41. Кравченко С. П. Мова як фактор нормоутворення та правоутворення : автореф. дис. ... канд. юр. наук. - Одеса, 2000. - 20 с.

42. Крейдлин Г. Е. Служебные слова в русском языке (семантические и синтаксические аспекты их изучения) : автореф. дис. ... канд. филол. наук. - Москва : Изд-во Моск. ун-та, 1979. -9 c.

43. Кустова Г. И. Национальный корпус русского языка как инструмент семантикограмматического исследования лексики / Г. И. Кустова, О. Н. Ляшевкая, Е.В.Падучева, Е. В. Рахилина // НТИ. Сер. 2. № 6, 2005. - С. 15.

44. Кучеренко І. К. Лексичне значення прийменника / І. К. Кучеренко // Мовознавство. 1973. - № 3. - C. 12-23.

45. Леонова М. В. Сучасна українська літературна мова: Морфологія / М. В. Леонова. Київ : Вища школа, 1983. - 264 с.

46. Леонтьева Н. Н. Роль связей в семантической разметке корпуса текстов / Н. Н. Леонтьева // «Корпусная лингвистика - 2004» : тр. междунар. конф. - Санкт-Петербург : Изд-во С.-Петерб. ун-та, 2004. - С. 201.

47. Лучик А. А. Російсько-український та українсько-російський словник еквівалентів слова / А. А. Лучик. - Київ : Довіра, 2003. - 496 с.

48. Ляшевская О.Н. О морфологическом стандарте Корпуса современного русского языка / О. Н. Ляшевская, В. А. Плунгян, Д. В. Сичинава // Научно-техническая информация. Cер. 2. Информационные процессы и системы. - 2005. - № 6. - С. 2-9.

49. Макагонов П. Формулы проверки подобия слов с обучением на примерах: построение и применение [Электронный ресурс] / П. Макагонов, М. Александров, А. Гельбух // Корпусная лингвистика - 2004 : тр. междун. конф. - Санкт-Петербург, 2004. URL : https://events.spbu.ru/eventsContent/files/corpling/corpora2004/Alexandrov art.pdf. - Загл. с экрана.

50. Малаховский Л. В. Омонимическая группа как лексическая микросистема / Л. В. Малаховский // Лингвистические исследования. Вопросы строя индоевропейских языков. Ч. 2. - Москва, 1975. - С. 184-194.

51. Малаховский Л. В. Теория лексической и грамматической омонимии / Л. В. Малаховский. - Ленинград : Наука, 1990. - 240 с.

52. Маслов О. Маяковский. Тайна смерти: точка над і поставлена / О. Маслов // Novaya Gazeta.RU. № 68 от 16 сентября 2002 г.

53. Маслов Ю. С. Омонимы в словарях и омонимия в языке (к постановке вопроса) / Ю. С. Маслов // Bопросы теории и истории языка. - Ленинград : Изд-во Ленингр. ун-та, 1963. - C. 198-202.

54. Мельчук И. А. Автоматический синтаксический анализ. Т. 1 : Общие принципы. Внутрисегментный синтаксический анализ / И. А. Мельничук. - Новосибирск : Ред.-издат. отдел Сибир. отд-ния АН СССР, 1964. - 356 с.

55. Морфологический анализ научного текста на ЭВМ. - Київ : Наукова думка, 1989. $264 \mathrm{c}$.

56. Мустайоки А. К вопросу о статусе эквивалентов слова типа потому что, 6 зависимости от, к сожалению / А. Мустайоки, М. В. Копотев // Вопросы языкознания. 2004. - № 3.- C. 88-107. 
57. Неровня Н. До 85-річчя лексичної картотеки / Н. Неровня // Лексикографічний бюлетень : зб. наук. праць. - Київ : Ін-т української мови НАН України. -2004. - Вип. 10. С. $12-18$.

58. Никитина С. Е. О семантическом эллипсисе в предложных сочетаниях: к постановке вопроса / С. Е. Никитина // Проблемы лингвистического анализа: Фонология, грамматика, лексикология. - Москва : Наука, 1966. - С. 140-147.

59. Ножов И. М. Процессор синтаксической сегментации русского предложения / И. М. Ножов // НТИ. Серия 2 : Информационные процессы и системы. - 2003. - № 11. - С. 26 37.

60. Орфографічний словник української мови. - Вид. 2-е, випр. та доп. - Київ : Довіра, 1999. - 989 с. - (Словники України).

61. Орфоепічний словник української мови. В 2 т. / за ред. М. М. Пещак, В. М. Русанівського. - Київ : Довіра, 2001. - Т. 1. - 955 с.; Т. 2 - 918 с. - (Словники України).

62. Перебийніс В. С. Статистичні методи для лінгвістів / В. С. Перебийніс. - Вінниця : Нова книга, 2002. - $110 \mathrm{c}$.

63. Перебийніс В. С. Статистичні параметри стилів / В. С. Перебийніс . - Київ : Наукова думка, 1967. - 259 с.

64. Перебийніс В. С. Статистичні та структурні лінгвістичні моделі / В. С. Перебийніс. Київ : Наукова думка, 1966. - 164 с.

65. Пиотровский Р. Г. Инженерная лингвистика и проблемы искусственного интеллекта / Р. Г. Пиотровский // Лингвистические проблемь искусственного интеллекта. - Москва, 1980. - С. 157-189.

66. Пиотровский Р. Г. Информационные измерения языка / Р. Г. Пиотровский. Ленинград : Наука, 1968. - 183 с.

67. Потебня А. А. Из записок по русской грамматике. В 4 т. Т. 1-2 / А. А. Потебня. Москва : Учпедгиз, 1958. - 536 с.

68. Похоже на подростков, которые хотели поиграть: разбираем письма «террористов» с лингвистом [Электронный ресур] //161.RU. Ростов-на-Дону онлайн. 31 січня 2018 p. - URL: https://161.ru/text/incidents/65901351. - Загл. с экрана.

69. Прадід Ю. Ф. Зв'язок юридичної лінгвістики 3 іншими правознавчими дисциплінами / Ю.Ф. Прадід // Матеріали III звітної наук.-практ. конф. проф.-викл. та курсант. складу Крим. ф-ту Нац. ун-ту внутр. справ. Ч. 2. - Сімферополь, 2001. - С. 137-143.

70. Прадід Ю. Ф. Юридична лінгвістика - нова наукова спеціальність / Ю. Ф. Прадід // Вісн. Львів. ін-ту внутр. справ. - 2001. - № 2. - С. 120-128.

71. Прадід Ю. Ф. Юридична лінгвістика як окрема галузь знань / Ю. Ф. Прадід // Вісн. Луганського ін-ту внутр. справ. - 2001. - № 3. - С. 246-55.

72. Резникова Т.И. Обзор общедоступных корпусов русского языка в Интернете / Т. И. Резникова // НТИ. Сер. 2 : Информационные процессы и системы. - 2005. - № 3. - С. 2 -9.

73. Рогожникова Р. П. Словарь эквивалентов слова: наречные, служебные, модальные единства / Р. П. Рогожникова. - Москва : Рус. яз., 1991. - 124 с.

74. Романовский В. И. Статистические задачи, связанные с цепями Маркова / В. И. Романовский. - Ташкент : Изд-тво УзФАН, 1940. - 380 с.

75. Рубашкин В. Ш. Словарная поддержка процедур семантической интерпретации предложных связей / В. Ш. Рубашкин // Компьютерная лингвистика и интеллектуальные технологии : тр. междун. конф. «Диалог-2005» (Звенигород, $1-6$ июня 2005 г.) / под ред. И. М. Кобозевой, А. - С. Нариньяни, В. П. Селегея. - Москва : Наука, 2005. - С. 430-435.

76. Синтаксический анализ научного текста на ЭВМ / Т. О. Грязнухіна та ін. - Киев : Наукова думка, 1999. - 272 с.

77. Сичинава Д. В. К задаче создания корпусов русского языка; Разработка синтаксически размеченного корпуса текстов / Д. В. Сичинава // Корпусная лингвистика $u$ лингвистические базы данных : докл. научн. конф. - Санкт-Петербург, 2002. - С. 40-50. 
78. Словарь омонимичных словоформ русского языка [Электронный ресурс]. - Москва, 2001. - URL : http://cfrl.ruslang.ru/homoforms/index.htm. - Загл. с экрана.

79. Словник української мови. В 11 т. / АН УРСР ; Інститут мовознавства ; ред. І. К. Білодід. - Київ : Наукова думка, 1970-1980.

80. Статистика речи : сб. статей / отв. ред. Р. Г. Пиотровский. - Ленинград : Наука, 1968. $-259 \mathrm{c}$.

81. Статистика речи и автоматический анализ текста : сб. научн. тр. / отв. ред. Р. Г. Пиотровский. - Ленинград : Наука, 1980. - 221 с. $432 \mathrm{c}$.

82. Сучасна українська літературна мова / ред. М. Я. Плющ. - Київ : Вища школа, 2001. -

83. Сучасна українська літературна мова: Морфологія / заг. ред. І. К. Білодід - Київ : Наукова думка, 1969. - 584 с.

84. Сучасна українська літературна мова: Синтаксис / заг. ред. І. К. Білодід - Київ : Наукова думка, 1972. - 516 с.

85. Український орфографічний словник / ред. В. М. Русанівський. - Київ : Довіра, 2009. - Вид. 4. - 1101 с. - (Словники України).

86. Український орфографічний словник. - вид. 4-е. / за ред. В. М. Русанівського. - Київ : Довіра, 2005. - 1069 с. - (Словники України).

87. Уотермен Д. Руководство по экспертным системам / Д. Уотермен, пер. с англ. Москва : Мир, 1989. - 388 с.

88. Федоров Е. Б. Омонимия и ИПС с автоматическим индексированием / Е. Б. Федоров // Информационные процессы и системы. НТИ. Сер. 2. - 1973. - № 7. - С. 1925.

89. Филипенко М. В. Проблемы описания предлогов в современных лингвистических теориях (обзор) / М. В. Филипенко // Исследования по семантике предлогов. - Москва : Рус. словари, 2000. - С. 12-54.

90. Фрумкина Р. М. Автоматизация исследовательских работ в лексикологии и лексикографии / Фрумкина Р. М. // Вопросы языкознания. - 1964. - № 2. - С. 114-119.

91. Фрэнсис У.Н.Проблемы формирования и машинного представления большого корпуса текстов / У.Н. Фрэнсис // Новое в зарубежной лингвистике, 1988. - Вып. ХІІІ Москва : Прогресс. - С. 334-353.

92. Хэррис 3. С. Метод в структуральной лингвистике // Звегинцев В. А. История языкознания XIX - XX веков в очерках и извлечениях. Ч. 2. - Москва : Просвещение, 1965. C. 209-227.

93. Цена слова: Из практики лингвистических экспертиз текстов СМИ в судебных процессах по искам о защите чести, достоинства и деловой репутации / ред. М. В. Горбаневский. - Москва : Галерия, 2001. - 184 с.

94. Черкасова Е. Т. Переход полнозначных слов в предлоги / Е. Т. Черкасова. - Москва : Наука, 1967. - 119 с.

95. Шаров С. А. Представительный корпус русского языка в контексте мирового опыта // НТИ. Сер. 2. Информационные процессы и системы. - 2003. - № 6. - С. 9-17.

96. Шевченко I. Автоматична парадигматизація лексичних одиниць у правописній системі української мови / І. Шевченко // Тези наукової конференції 3 проблем сучасного українського правопису і термінології. - Київ, 1997. - С. 99-100.

97. Шевченко I. В.Автоматизована дистрибуція наголосів у словозмінній парадигмі українського дієслова / І. В. Шевченко // Мовознавство. - 2001. - № 5. - С. 26-30.

98. Шевченко I. В. Алгоритмічна словозмінна класифікація української лексики / І. В. Шевченко // Мовознавство. - 1996. - № 4-5. - С. 40-44.

99. Шевченко I. В. Моделі та алгоритмічно-програмне забезпечення лексикографічних систем : автореф. дис. ... канд. техн. наук. - Київ, 2000. - 19 с.

100. Шеннон К. Работы по теории информации и кибернетике / К. Шеннон. - Москва : Иностранная лит-ра, 1963. - 832 с. 
101. Шимкова М. Репрезентативность корпуса как лингвистическая проблема / М. Шимкова // Прикладная лингвистика в поиске новых nутей MegaLing'2005 : Мат. междунар. конф. (Крым, Меганом, 27 июня - 2 июля 2005 г.). - Симферополь : ТНУ им. В. И. Вернадского, 2005. - С. 55.

102. Шипнівська О. О. Кількісна та якісна характеристика типів морфологічних омонімів сучасної української мови / О. О. Шипнівська // Актуальні проблеми української лінгвістики: теорія і практика: зб. наук. праць. - Київ, 2005. - С. 36-42.

103. Шипнівська О. О. Формування реєстру омографів сучасної української мови / О. О. Шипнівська // Мовні та концептуальні картини світу: зб. наук. праць. - Вип. 14. Кн. 2. - Київ, 2004. - С. 255-259.

104. Широков В. А. Інформаційна теорія лексикографічних систем / В. А. Широков. Київ : Довіра, 1998. - 330 с.

105. Широков В. А. Корпусна лінгвістика : монографія / В. А. Широков, О. В. Бугаков, Т. О. Грязнухіна, О. М. Костишин, М. Ю. Кригін; НАН України, Укр. мов.-інформ. фонд. Київ : Довіра, 2005. - 472 с.

106. Широков В. А. Словники України. Інтегрована лексикографічна система : Словозміна. Транскрипція. Фразеологія. Синонімія. Антонімія [Електронне видання] / В. А. Широков, О. Г. Рабулець, Н. М. Сидорчук, І. В. Шевченко, К. М. Якименко ; Нац. акад. наук України ; Укр. мов.-інформ. фонд. - Версія 4.1. - 1 електр. опт. диск. (CD-ROM) - Київ : Довіра, 2010. - (Словники України). - Назва з етикетки диска.

107. Широков В. А. Феноменологія лексикографічних систем / В. А. Широков. - Київ : Наукова думка, 2004. - 327 с.

108. Яглом А. М. Вероятность и информация / А. М. Яглом, И. М. Яглом. - Москва : Наука, 1973. - С. 68-128, 236-273, 441-483.

109. Ahrenberg L. Evaluation of Word Alignment System [Electronic resource] / L. Ahrenberg, M. Merkel, A. Sågval Hein, J. Tiedemann // Proceeding of LREC-2000. Athens, 2000. - URL : http://web.eecs.umich.edu/ mihalcea/wa/papers/EvalWASystems.pdf. - Title from the screen. - Title from the screen

110. Al-Mosaiwi M. People with depression use language differently - here's how to spot it [Electronic resource] / Mohammed Al-Mosaiwi // Clinical Psychological Science (University of Reading). - URL : https://www.peacequarters.com/people-suffering-from-depression-use-languagedifferently-than-others/. - Title from the screen.

111. Altenberg B., Aijmer K. The English-Swedish Parallel Corpus. A resource for contrastive research and translation studies. In Corpus Linguistics and linguistic theory/ B. Altenberg, K. Aijmer // Papaers from the twentieth international Conference on English Language Research on Computerized corpora (ICAME 20), Freiburg im Breisgau, 1999. ed. By Christian Mair and Mariane Hundt. - Pp. 15-33.

112. Atkins B. T. S. Computational Approaches to the Lexicon: An Overview / B. T. S. Atkins, B. Levin, A. Zampolli // B. T. S. Atkins and A. Zampolli (eds.) Computational Approaches to the Lexicon. Oxford: Oxford University Press. - Pp. 17-48.

113. Baker M. Corpora in translation studies // An overview and some suggestions for future research. Target 7(2), 1995. - Pp. 223-243.

114. Biber, Douglas and Conrad, Susan and Reppen, Randi: Corpus Linguistics // Investigating Language Structure and Use. Cambridge University Press, 1998. - Pp. 281-284.

115. Borin L. ... and never the twain shall meet? / Lars Borin // Borin, Lars (ed.) Parallel Corpora, Parallel Worlds. Selected Papers from a symposium on parallel and comparable corpora at Uppsala University, Sweden, 22-23 April 1999. Amsterdam - New York, NY: Rodopi, 1999. Pp. 1-43.

116. Bouma G. Corpus-based Acquisition of Collocational Prepositional Phrases / G. Bouma, B. Villada // Language and Computers, 2001. - Pp. 18. 
117. Bowker L. Towards a Methodology for Exploiting Specialized Target Language Corpora as Translation resources / L. Bowker // International Journal of Corpus Linguistics. Amsterdam: John Benjamins. 5(1), 2000. - Pp. 17-52.

118. Čmejrek M. Automatic Extraction of Terminological Translation Lexicon from CzechEnglish Parallel Texts / M. Čmejrek, J. Cuř́n // International Journal of Corpus Linguistics. Vol 6. (Special Issue) John Benjamin Publishing Company. - Amsterdam-Philadalphia, 2001. - Pp. 1-12.

119. Corpus Encoding Standard [Electronic resource]. - URL: http://www.cs.vassar.edu/CES/index.html. - Title from the screen.

120. Erjavec T. The ELAN Slovene-English Aligned Corpus / Tomaž Erjavec // Proceeding of the Machine Translation Summit VII. Singapore. 1999. - Pp. 349-357.

121. Fillmore Ch. J. «Corpus Linguistics» and «Computer-aided armchair linguistics» / Ch. J. Fillmore // Jan Svartvik (ed.) Directions in Corpus Linguistics. Proceedings of Nobel Symposium 82. (Stockholm, 4 - 8 August 1991). - Berlin-New York: Mouton de Gruyter. - Pp. 35-61.

122. Francis W. Language Corpora B. C. / W. Francis // Jan Svartvik (ed.) Direction in Corpus Linguistics. Proceeding of Nobel 82. Stockholm, 4 -8. August 1991. - Berlin-New York. Mouton de Gruyter. - Pp. 17-35.

123. Gale W. A. A Program for Aligning Sentences in Bilingual Corpora / W. A. Gale, K. W. Church // Computational Linguistics, 1993. - 19 (1). - Pp. 75-102.

124. Hajichova E. Language Resources Need Annotations To Make Them Really Reusable: The Prague Dependency Treebank / E. Hajichova, J. Panevova, P. Sgall // The first International Conference on Language Resources and Evaluation, 1998. - Pp. 18.

125. ISO 2709:1996 Information and documentation. Format for Information Exchange [Electronic resource]. - URL : https://www.iso.org/standard/7675.html. - Title from the screen.

126. Johansson, S. Towards a miltilingual corpus for contrastive analysis and translation studies / Stig Johansson // Borin, Lars (ed.). Parallel Corpora, Parallel Worlds. Selected Papers from a symposium on parallel and comparable corpora at Uppsala University. (Sweden, 22 - 23 April 1999). - Amsterdam-New York, NY: Rodopi. - Pp. 47-59.

127. Leech G. Corpus Annotation Schemes / G. Leech // Literary and Linguistics Computing. 1993. Vol. 8, N 4. - Pp. 275-281.

128. MARC 21 Concise format for bibliographic data. Library of Congress. Network Developement and MARC Standart Office] [Electronic resource]. - URL : http://www.loc.gov/marc/bibliographic/ecbdhome.html. - Title from the screen.

129. Mauranen A. Strange things in translated language: a study of corpora // Maeve Olohan (ed.) Intercultural faultlines. Research models in translation studies. Textual and cognitive aspects. Manchester, Northhampton: St. Jerome Publishing, 2000. - Pp. 18.

130. McEnery T. Corpus Linguistics / T. McEnery, A. Wilson // An Introduction. 2nd Edition. - Edinburgh: Edinburgh University Press, 2001. - Pp. 207.

131. Merkel, M. The PLUG Link Annotator - iterative construction of data from parallel corpora / Magnus Merkel, Mikael Anderson, Lars Ahrenberg // Borin, Lars (ed.) Parallel Corpora, Parallel Worlds. Selected Papers from a symposium on parallel and comparable corpora at Uppsala University (Sweden, 22-23 April 1999). - Amsterdam-New York, NY: Rodopi. - Pp. 151-168.

132. Microsoft SQL Server [Electronic resource] - URL : https://www.microsoft. com/en-us/sql-server/. - Title from the screen.

133. NIMARC Manual: Bibliographic Format, 1994 [Electronic resource]. - URL : https://www.ifla.org/publications/unimarc-formats-and-related-documentation. - Title from the screen.

134. Oakes M. Statistics for Corpus Linguistics / M. Oakes. - Edinburg University Press, 1998. $-118 \mathrm{p}$.

135. Oliveira C. Recognising Complex Prepositions Prep+N+Prep as Negative Patterns [Electronic resource] / C. Oliveira, M. Garrão, L. A. Amaral // Automatic Term Extraction from Texts. - URL : http://citeseerx.ist.psu.edu/viewdoc/download?doi=10.1.1.473.5377\&rep=rep1\&type=pdf. Title from the screen. 
136. Porter M. An Algorithm for Suffix Stripping / M. Porter // Program, 1980. N14. Pp. 130-137.

137. Rundell M. The Corpus of the future, and the future of the corpus. 1996. $-118 \mathrm{p}$.

138. Sågval, H. A. The PLUG project: parallel corpora in Linköping, Uppsala, Göteborg: aims and achievements / Hein Anna Sågval // Borin, Lars (ed.) Parallel Corpora, Parallel Worlds. Selected Papers from a symposium on parallel and comparable corpora at Uppsala University, Sweden, 22-23 April 1999. - Amsterdam-New York, NY: Rodopi. - Pp. 61-78.

139. Salkie R. How can linguistics profit from parallel corpora? [Electronic resource] / R. Salkie // Borin, Lars (ed.). Parallel Corpora, Parallel Worlds. Selected Papers from a symposium on parallel and comparable corpora at Uppsala University, Sweden (22 - 23 April 1999). Amsterdam-New York, NY: Rodopi. - Pp. 93-109. - URL : http://www.bton.ac.uk/edusport/languages/html/intersect.html. - Title from the screen.

140. Stahl, P. Building and Processing a multilingual corpus of parallel texts / Peter Stahl // Borin, Lars (ed.) Parallel Corpora, Parallel Worlds. Selected Papers from a symposium on parallel and comparable corpora at Uppsala University, (Sweden, 22-23 April 1999). - Amsterdam-New York, NY: Rodopi. - Pp. 169-179.

141. Svartvik J. Corpus Linguistics Comes of Age / Jan Svartvik // Jan Svartvik (ed.) Directions in Corpus Linguistics. Proceedings of Nobel Symposium 82. (Stockholm, $4-8$ August 1991). - Berlin-New York: Mouton de Gruyter. - Pp. 7-17.

142. Tadić M. Procedures in Building the Croatian-English Parallel Corpus / M. Tadić // International Journal of Corpus Linguistics. - Vol 6. (Special Issue) John Benjamin Publishing Company. - Amsterdam-Philadalphia, 2001. - Pp. 107-127.

143. Teubert W. Comparable or Parallel corpora / W. Teubert // International Journal of Lexicography. - Vol. 9, Issue 3, September 1996. - Oxford University Press. 9(3). - Pp. 238-264.

144. The Brown Standard Corpus of American English. - Brown, 1964. - 386 p.

145. Tiedemann, J. Uplug - a modular corpus tool for parallel corpora [Electronic resource] / Jörg Tiedemann // Borin, Lars (ed.) Parallel Corpora, Parallel Worlds. Selected Papers from a symposium on parallel and comparable corpora at Uppsala University, Sweden, 22-23 April 1999. Amsterdam-New York, NY: Rodopi. - Pp. 181-197. - URL : http://numerus.ling.uu.se/ corpora/plug/. - Title from the screen. 


\title{
ЛІНГВІСТИЧНО-ІНФОРМАЦІЙНІ СТУДІї
}

ПРАЦІ УКРАЇНСЬКОГО МОВНО-ІНФОРМАЦЙНОГО ФОНДУ НАН УКРАЇНИ

\author{
У П’ЯТИ ТОМАХ
}

За загальною редакцією $B$. А. Широкова

\author{
TOM IV \\ КОРПУСНА ТА КОГНІТИВНА \\ ЛІНГВІСТИКА
}

Редактор Н. В. Щербакова

\begin{abstract}
Видавець:
УКРАЇНСЬКИЙ МОВНО-ІНФОРМАЦІЙНИЙ ФОНД

НАЦІОНАЛЬНОЇ АКАДЕМІЇ НАУК УКРАЇНИ

03039, м. Київ, Голосіївський проспект, буд. 3

Свідоцтво про внесення суб' єкта видавничої справи

до державного реєстру видавців,

виготовників і розповсюджувачів видавничої продукції

серія ДК № 4652
\end{abstract}

Підписано до друку 26.10.2018. Формат 70х100 1/16

Ум. друк. арк. 22,1. Обл.-вид. арк. 13,7.

Тираж 300

Виготовлювач:

«Видавництво Ліра-К»

Свідоцтво № 3981, серія ДК

031156 м. Київ, вул. Ф. Пушиної, 27, оф. 20-22

Тел./факс (044) 247-93-37; 228-91-12

Сайт: lira-k.com.ua

Редакція: zv_lira@ukr.net 